
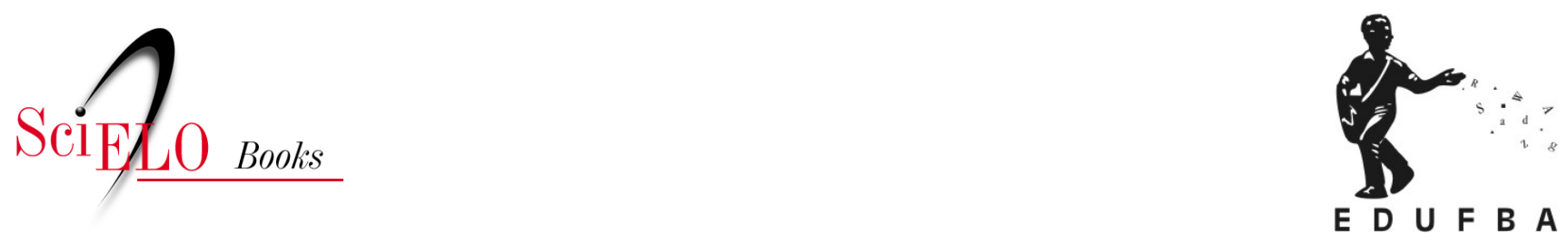

\title{
E-science e políticas públicas para ciência, tecnologia e inovação no Brasil
}

\author{
Valdinéia Barreto Ferreira
}

\section{SciELO Books / SciELO Livros / SciELO Libros}

FERREIRA, V.B. E-science e políticas públicas para ciência, tecnologia e inovação no Brasil [online]. Salvador: EDUFBA, 2018, 256 p. ISBN: 978-85-232-1865-2.

https://doi.org/10.7476/9788523218652.

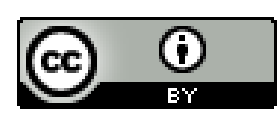

All the contents of this work, except where otherwise noted, is licensed under a Creative Commons Attribution $\underline{4.0 \text { International license. }}$

Todo o conteúdo deste trabalho, exceto quando houver ressalva, é publicado sob a licença Creative Commons Atribição 4.0. 


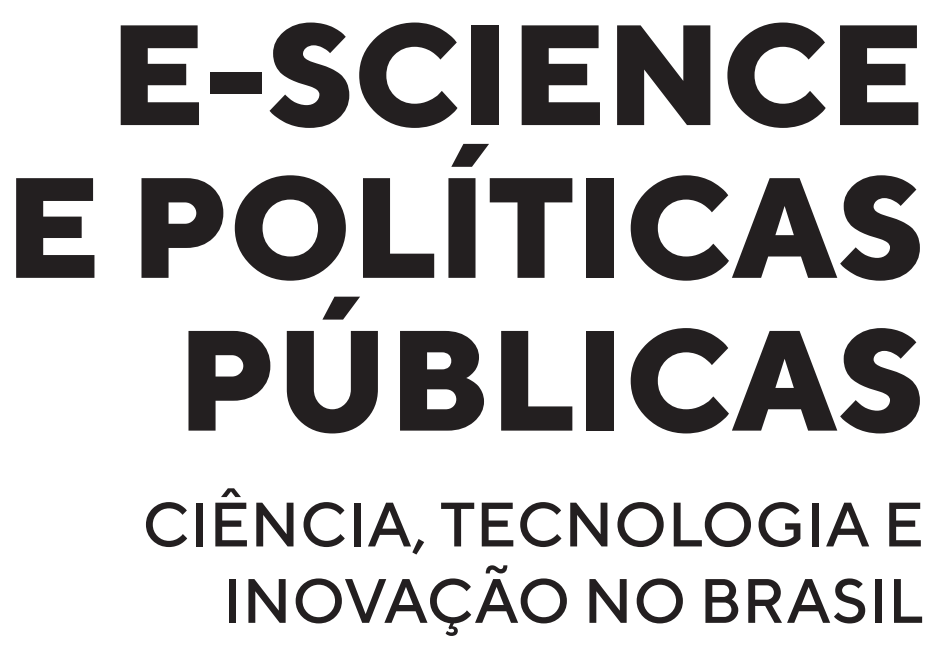




\title{
UNIVERSIDADE FEDERAL DA BAHIA
}

\author{
Reitor \\ João Carlos Salles Pires da Silva \\ Vice-reitor \\ Paulo Cesar Miguez de Oliveira \\ Assessor do Reitor \\ Paulo Costa Lima
}

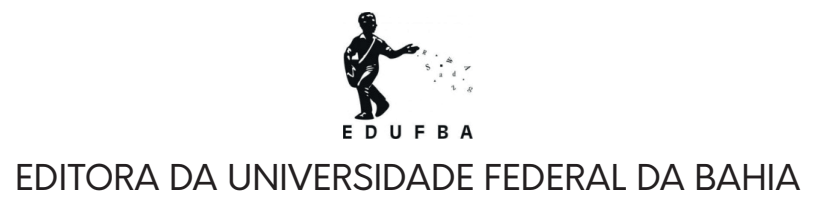

\author{
Diretora \\ Flávia Goulart Mota Garcia Rosa \\ Conselho Editorial \\ Alberto Brum Novaes \\ Angelo Szaniecki Perret Serpa \\ Caiuby Alves da Costa \\ Charbel Niño El Hani \\ Cleise Furtado Mendes \\ Evelina de Carvalho Sá Hoisel \\ José Teixeira Cavalcante Filho \\ Maria do Carmo Soares de Freitas \\ Maria Vidal de Negreiros Camargo
}




\section{VALDINÉIA BARRETO FERREIRA}

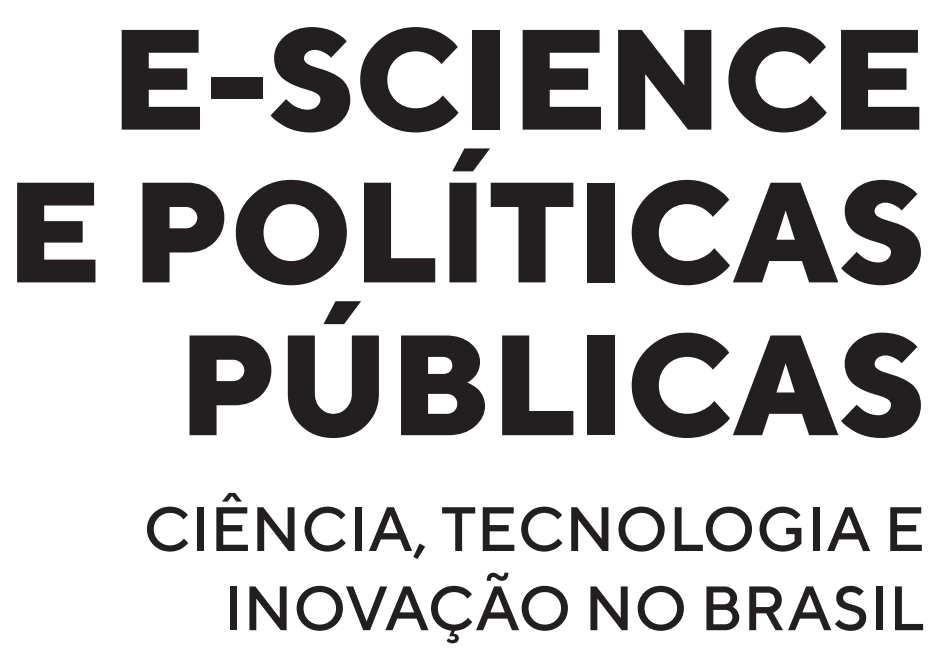

Salvador

EDUFBA 2018 
2018, Valdinéia Barreto Ferreira.

Direitos para esta edição cedidos à Edufba.

Feito o Depósito Legal.

Grafia atualizada conforme o Acordo Ortográfico da Língua Portuguesa de I99o, em vigor no Brasil desde 2009.

Capa e Projeto Gráfico

Edufba

Revisão e Normalização

A autora

Sistema de Bibliotecas - UFBA

F383e Ferreira, Valdinéia Barreto.

E-science e políticas públicas para ciência, tecnologia e inovação no Brasil / Valdinéia Barreto Ferreira. - Salvador: EDUFBA, 2018.

256 p. : il. col.

ISBN 978-85-232-I707-5

I. Colaboração acadêmico-industrial. 2. Parceria de pesquisa e desenvolvimento. 3. Inovação tecnológica 4. Parceria público-privada I. Título. II.

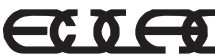
ASOCIACION DE EDITORIALES UNIVERSITARIAS DE AMERICA LATINA Y EL CARIBE

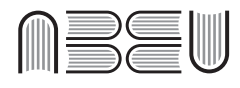

Associação Brasileira das Editoras Universitárias Editora filiada à:
$\mathrm{CBaL}$

Câmara Bahiana do Livro

Editora da UFBA

Rua Barão de Jeremoabo, s/n - Campus de Ondina

40I70-II5 - Salvador - Bahia

Tel.: + 55 7I 3283-6164

www.edufba.ufba.br / edufba@ufba.br 


\section{SUMÁRIO}

7 PREFÁCIO

9 APRESENTAÇÃO

13 E-SCIENCE

15 Compreensão conceitual, origem e base fundante da e-Science

20 Modelo de infraestrutura e-Science

31 POLÍTICAS PÚBLICAS PARA FOMENTO CIENTÍFICO, TECNOLÓGICO E DE INOVAÇÃO

33 Ciência, tecnologia e inovação: um tripé de peso

39 Sistema Nacional de Ciência, Tecnologia e Inovação

45 Programa Institutos Nacionais de Ciência e Tecnologia

57 A PRÁTICA COLABORATIVA: TRADIÇAO E CONTEMPORANEIDADE

57 Colaboração: práticas, tradição e contemporaneidade

67 Fios que tecem uma rede colaborativa

77 FAZER CIENTÍFICO E TECNOLÓGICO

80 Tramas da Teoria Ator-Rede

97 NANOTECNOLOGIA E SUA IMPORTÂNCIA NO CONTEXTO BRASILEIRO

101 Mundo das nanoestruturas: conceito, origem e fundamentos da Nanotecnologia

107 INSTITUTOS NACIONAIS DE CIÊNCIA E TECNOLOGIA DE

NANOTECNOLOGIA

108 Identificação dos INCTS e informantes

111 Perfil dos pesquisadores

118 Natureza do grupo

120 Instituto Nacional de Ciência e Tecnologia de Catálise em Sistemas Moleculares e Nanoestruturados (CATÁLISE)

122 Instituto Nacional de Ciência e Tecnologia em Materiais Complexos Funcionais (INOMAT) 
123 Instituto Nacional de Ciência e Tecnologia dos Materiais em Nanotecnologia (INCTMN)

124 Instituto Nacional de Ciência e Tecnologia de NanoBioEstruturas e Simulação BioMolecular (NANOBIOSIMES)

126 Instituto Nacional de Ciência e Tecnologia de Nanobiofarmacêutica (NANOBIOFAR)

128 Instituto Nacional de Ciência e Tecnologia para Marcadores Integrados (INAMI)

129 Instituto Nacional de Ciência e Tecnologia em Nanomateriais de Carbono (NANOCARBONO)

132 Instituto Nacional de Ciência e Tecnologia de Sistemas Micro e Nanoeletrônicos (NAMITEC)

133 Instituto Nacional de Ciência e Tecnologia de Nanobiotecnologia do Centro-Oeste e Norte (NANOBIOTECNOLOGIA)

135 Instituto Nacional de Ciência e Tecnologia de Nanodispositivos Semicondutores (DISSE)

139 PRÁTICAS E REDES COLABORATIVAS PARA INOVAÇÃO NOS INCTS DA ÁREA DE NANOTECNOLOGIA

140 Práticas colaborativas nos INCTs

166 Redes de práticas colaborativas para inovação

178 Produção científica dos pesquisadores dos INCTs de Nanotecnologia

182 Infraestrutura e suporte para pesquisa: INCTs e modelo e-Science

205 EVIDÊNCIAS DE PRÁTICAS COLABORATIVAS, PRODUÇÃO CIENTÍFICA E E-SCIENCE

221 CONCLUSÃO

229 REFERÊNCIAS

255 APÊNDICE A - MODELO DE ANÁLISE

256 APÊNDICE B - CARACTERIZAÇÃO METODOLÓGICA DA PESQUISA 


\section{PREFÁCIO}

A intensificação do uso de tecnologias de informação em rede, a ampliação da cooperação internacional, a necessidade de redução de custos e a consolidação da web colaborativa na integração das diversas etapas e contextos de realização de pesquisas científicas ensejou o surgimento de novas formas de se fazer ciência em âmbito internacional.

Tornaram-se perceptíveis as experiências de horizontalização da instância gerativa dos discursos científicos e a paulatina ruptura das fronteiras dos espaços acadêmicos tradicionais com impactos significativos na cultura epistêmica contemporânea.

Assim, expressões como ciência aberta, comunicação direta, humanidades digitais, colaboratório, desenvolvimento sustentável, redes sociais acadêmicas, compartilhamento, repositórios digitais, big data, interoperabilidade e dados científicos abertos tornaram-se cada vez mais frequentes e almejados pela comunidade científica.

Nessas circunstâncias, a e-Science, abordagem que se refere ao termo enhance (melhoria, aprimoramento, intensificação) e ao fortalecimento dos laboratórios e grupos de pesquisa como ambientes digitais colaborativos, surgiu como uma oportunidade de se pensar os novos contextos e práticas científicas.

No Brasil, a infraestrutura necessária à indução dessas novas práticas científicas foi assumida como política pública para a ciência, tecnologia e inovação em 2008. Nesse sentido, o Ministério da Ciência e Tecnologia (MCT) consolidou inúmeros institutos de pesquisa multicêntricos orientados à "melhor distribuição 
nacional da pesquisa científico-tecnológica, e a qualificação do país em áreas prioritárias para o seu desenvolvimento regional e nacional”. Isso foi possível devido à indução dos Institutos Nacionais de Ciência e Tecnologia (INCT).

Em "e-Science e políticas públicas para ciência, tecnologia e inovação no Brasil” Valdinéia Barreto Ferreira nos brinda com a oportunidade de conhecer os aspectos teóricos e as dimensões sócio-históricas de e-Science, bem como de compreender os meandros, desafios e desdobramentos de se consolidar essa prática científica como política pública nacional.

Acredita-se que o olhar atento em direção às perspectivas internacionais fomentadas pelas novas práticas e a compreensão do papel dos diferentes atores sociais implicados (cientistas, instituições, empresas, mercado consumidor e a instância governamental), instigados por esse trabalho, podem nos auxiliar na condução de uma experiência cidadã no contexto cientifico.

Maria Aparecida Moura | Professora titular da UFMG 


\section{APRESENTAÇÃO}

A mudança na forma e atores envolvidos no processo de construção do conhecimento, bem como na potência do alcance dessa construção, é evidente na sociedade científica contemporânea. Essa interfere, em parte dos elementos essenciais que compõem a economia do conhecimento identificados como: a ciência com os seus produtos e derivados, o sistema político, econômico e financeiro em que está inserida e ocorre suas atividades, a comunidade científica, os tecnólogos, as agências de fomento entre outros.

A $e$-Science ${ }^{1}$ caracteriza-se pela alocação dos recursos digitais, que subsidiam a construção de infraestruturas computacionais que darão suporte às práticas científicas e, em especial, às práticas colaborativas realizadas pelos pesquisadores e como extensão, aos elementos que compõem a economia do conhecimento. Ao incorporar novos suportes tecnológicos, a comunidade científica renova os instrumentos do seu fazer e abre espaço para a substituição da investigação isolada praticada desde os primórdios da Ciência por alguns pesquisadores.

A nova conjuntura da produção do conhecimento requer associações, negociações, alinhamentos, estratégias e competências que liguem os elementos envolvidos nesse processo de construção. Decisões políticas são tomadas com base em avaliações que a comunidade cientifica realiza sobre a dinâmica dessa

1 A e-Science será detalhada no primeiro capítulo deste livro, mas em termos gerais pode ser definida como a utilização de uma infraestrutura de apoio a realização de pesquisas, cercada de ferramentas computacionais para analisar grandes conjuntos de dados científicos de modo colaborativo (E-SCIENCE, 2012a). 
produção. Justifica-se nesse momento a pertinência de incluir, as políticas públicas para fomento científico, tecnológico e de inovação na discussão. Apresenta-se o Programa Institutos Nacionais de Ciência, Tecnologia e Inovação, criado pela Portaria MCT n ${ }^{\circ} 429$, de 17 de julho de 2008 (BRASIL, 2008), como representante das políticas públicas na conjuntura estudada.

A Teoria Ator-Rede (Actor-Network-Theory - ANT) $)^{2}$ desenvolvida em meados da década de 1980 pelos autores Bruno Latour, Michael Callon, John Law, entre outros, inserida no âmbito dos Estudos Sociais da Ciência ou Estudos da Ciência, Tecnologia e Sociedade, ${ }^{3}$ configurou-se um recurso teórico-metodológico valioso para o desenvolvimento do estudo. Isso ajudou no estreitar do olhar e atenção redobrada no decorrer do estudo. O desnudar da ANT propiciou refletir sobre um fazer científico que "inclui na análise sociológica da atividade científica, além dos atores sociais (pessoas e grupos), os artefatos, denominados atores não humanos." (ARAÚJO et al., 2009, p. 136). Esses atores e artefatos estão muito bem representados nessa obra pelos elementos que compõem o seu conglomerado, ou seja: os INCTs, as agências de fomento, as universidades e empresas, o aparato tecnológico dos laboratórios de pesquisa, as práticas colaborativas em rede realizadas, a comunidade científica etc.

A Ciência da Informação foi convidada para o dialogo proposto, pois preocupa-se com a informação científica desde a sua origem, como salienta Mueller (2007), e insere-se entre os seus desafios identificar como os outros domínios do conhecimento a tratam. Almeida (2008, p. 37) acrescenta ainda que a definição da área, como campo científico, leva "em conta suas fronteiras e zonas de interlocução com outras áreas, bem como os suportes teóricos e metodológicos que a caracterizam”. Relacionada à assertiva acima indicada, sobre as atribuições e desafios da área da Ciência da Informação, adentrou-se nos domínios da área de Nanotecnologia para identificar suas práticas colaborativas e analisar a e-Science

2 Opta-se por manter o acrônimo ANT da expressão em inglês Actor-Network-Theory, com base na justificativa e recomendação de Souza e Sales Junior na apresentação de Latour (2012) para ser fiel ao estilo peculiar de escrever do referido autor. Observa-se também o que explica Latour (2012) sobre a escolha do nome para a ANT.

3 Em Latour (2012, p. 139) é apresentada uma nota quanto à sua vinculação com esses campos de estudo, na qual ele diz: "embora nunca tenha usado esses rótulos, exatamente por que eles conservam vivos os diferentes domínios que têm de dissolver, não tem problemas em dizer que a ANT pertence aos campos da ciência, da tecnologia e da sociedade." 
como modelo estruturante do seu fazer científico. A escolha por esta área do conhecimento, para completar o conjunto estudado, pautou-se na importância que ela representa para o cenário mundial como fator de desenvolvimento futuro para a sociedade, ou seja, uma tecnologia revolucionária emergente, a qual está sintonizada com os segmentos tecnológicos, sociais, científicos e inovadores da sociedade contemporânea.

A escolha do "como" desenvolvolver o trabalho foi considerada como uma das grandes contribuições que a pesquisa agregou para as áreas de conhecimento que permeou. ${ }^{4} \mathrm{O}$ exercício de correlação entre a ANT, os objetivos da pesquisa e os métodos mistos pautaram-se no exame das cinco grandes incertezas das instituições sociais, indicadas por Latour (2012) como: a natureza dos grupos; a natureza das ações; a natureza dos objetos; a natureza dos fatos e; o tipo de estudos realizados sob o rótulo de Estudos Sociais. A convergência entre as incertezas pontuadas por Latour e a problemática identificada no contexto investigado foi realizada, assim como a apropriação dos conceitos e uso das técnicas pertinentes aos métodos utilizados. Uma tentativa de tradução do arcabouço da ANT para o contexto da pesquisa e uma articulação satisfatória entre suas seis etapas a saber: identificação dos INCTs e informantes; identificação das práticas e redes colaborativas, levantamento da produção cientifica; identificação da infraestrutura, suporte para pesquisa dos INCTs e correlação com o modelo de infraestrutura e-Science; confirmação das evidências e fatos que balizaram a pesquisa; e a Redação da tese.

Convida-se o leitor a realizar o percurso transcorrido pela autora e apropriar-se das suas conjecturas e descobertas em um arcabouço cheio de nuances e reminiscências.

4 O modelo de análise e a caracterização metodológica utilizados na pesquisa desenvolvida que deu origem a esse livro são apresentados no final do livro como Apêndices A e B. 


\section{E-SCIENCE}

O cerne da transformação que estamos vivendo na revolução atual refere-se às tecnologias da informação, processamento e comunicação. A tecnologia da informação é para esta revolução o que as novas fontes de energia foram para as revoluções industriais sucessivas, do motor a vapor à eletricidade, aos combustíveis fósseis e até mesmo à energia nuclear. (CASTELL, 2006, p. 68)

A necessidade de medir como forma de comprovação se faz presente na Ciência em muitas áreas do conhecimento e tornou-se prática constante. Conforme Cesar Junior (2011, p. 7), “a evolução da ciência está profundamente ligada à evolução dos instrumentos que permitem a realização de observações. Em muitos momentos a Ciência precisou aguardar o aparecimento de tecnologias apropriadas de medição dos fenômenos de interesse.” A refutação, aprimoramento e proposição de teorias e pressupostos dependiam dessas tecnologias.

A necessidade de uma tecnologia adicional que suportasse o desenvolvimento das pesquisas e aliviasse o isolamento do pesquisador foi o impulso extra para o aparecimento da e-Science; um composto de hardware, software e um preponderante cunho colaborativo. Esse foi o empurrão necessário para o desenvolvimento de uma metodologia cujo uso intensivo de dados fundamentava a busca para o tratamento dos insumos de um fazer científico abundante. Em seu bojo identifica-se a preocupação crescente pela captura, curadoria e análise dos dados, uma ajuda de peso para que o completo ciclo da pesquisa se concretize. 
A e-Science caracteriza-se como um novo paradigma da Ciência, a qual marca sua presença e destaca a transição normal e algumas vezes imperceptível no curso evolutivo da Ciência. Apresenta-se paralelamente a outras manifestações científicas, em alguns aspectos, chega até a sobrepô-las.

Na Figura 1, resgatam-se os paradigmas da Ciência segundo Gray e Szalay (2007), os quais ilustram a evolução da Ciência e a enquadram em um período temporal no qual surge a $e$-Science. Realizou-se um passeio pelos primórdios da Ciência e identificaram-se os fenômenos naturais como determinantes do curso seguido, um momento em que a Ciência era eminentemente empírica. A teoria tornou-se predominante no período seguinte com seus modelos e generalizações. A computação ao sobrepô-la, ditou as regras seguintes e passou a conduzir de modo consistente os rumos da Ciência. A atualidade vivencia um período marcado pelo enorme volume de dados, exploração da tecnologia de larga escala e a colaboração entre diversos domínios do conhecimento, características que assinalam a $e$-Science. Esse é um paradigma emergente, o qual influenciou de modo preponderante os rumos tomados no desenvolvimento da pesquisa científica contemporânea.

Figura 1 - Paradigmas da Ciência

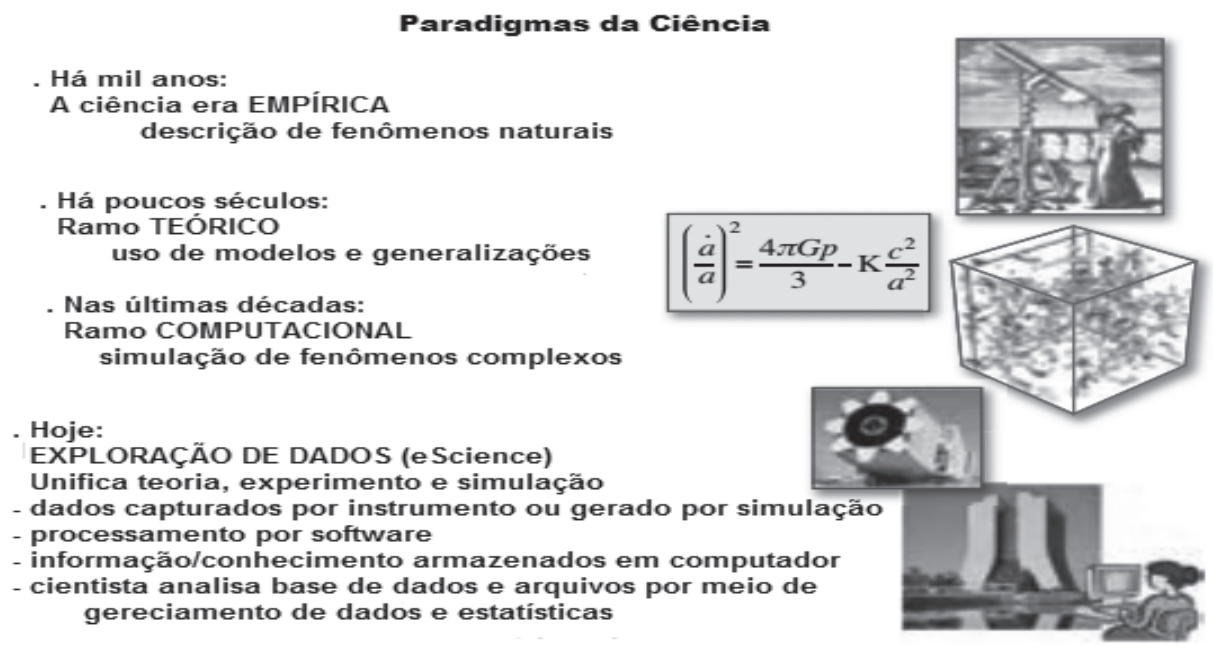

Fonte: Adaptado de Gray e Szalay (2007). 
Contudo, questões acerca da atribuição de rótulos aos eventos científicos são temas de debate na comunidade científica constantemente, e Bell (2011, p. 11) demonstra preocupação ao afirmar que "disciplinas científicas não podem ser facilmente encapsuladas em alguns poucos números e nomes compreensíveis [...]". Essa assertiva encontra consonância em sinalizações anteriormente pautadas por Jankowski (2009), ao alertar, para a adoção dos rótulos frequentemente debatidos e contestados, os quais marcaram os diversos eventos históricos da humanidade. As mudanças nem sempre ilustram as reais transformações e muito do que se tem propagado como novo e revolucionário é frequentemente a aplicação de práticas organizacionais e de boa investigação no âmbito da Internet, reflexões que incitam a se buscar fundamentos que permitam identificar a verdadeira natureza de um termo novo e tão potente como a $e$-Science.

\section{Compreensão conceitual, origem e base fundante da e-Science}

O termo e-Science ou (eScience), originário no Reino Unido e predominante no restante da Europa, foi cunhado por John Taylor, no ano de 1999, ${ }^{1}$ quando ocupava o cargo de diretor geral do Research Councils UK, conforme Jankowski (2007). Traduzido para o português como e-Ciência, este termo adquiriu um significado que representa a potência da ciência melhorada com o uso intensivo das TICs e sua ampliação em torno de um esforço colaborativo.

Em estudo realizado por Costa e Cunha (2015, p. 128), o qual apresenta a análise de publicações sobre a temática e-Science na área da Ciência da Informação, os autores inferem que: após buscas exaustivas nas bases de dados internacionais Education Resources Information Center (ERIC), Library and Information Science Abstracts (LISA), Library e Information Science \& Technology Abstracts (LISTA) e Web of Science, "ainda não há trabalho na literatura sobre a área atrelado ao fenômeno da $e$-Science que identifique a sua comunidade, os autores que mais publicam, bem como os países que produzem essa literatura." Eles observam ainda que "não há um mapeamento a respeito do tema que facilite a identificação dos canais de comunicação utilizados pela comunidade." O estudo realizado evidência a pertinência de pesquisas relacionadas a $e$-Science entrelaçada à área

1 Segundo Tolle e colaboradores (2011, p. 235), o termo foi cunhado no ano 2000. 
da Ciência da Informação, devido a relevância e atualidade do tema e produção na área ainda pequena.

Ao referir-se ao documento do Research Councils UK, ${ }^{2}$ Vaz (2011, p. 20) ressalta que o significado da partícula "e" do termo "e-Science normalmente não é explicado mas, [...] sem dúvida, começou com o significado de eletronic (eletrônico) e agora representa melhor enhanced (melhorada) ou enabled (habilitada)". Considera-se pertinente neste estudo, o emprego da partícula "e" com o sentido do termo inglês enhanced (melhorada), por refletir de modo apropriado o poder atribuido à Ciência na contemporaneidade. Na pesquisa em curso adota-se o termo e-Science com o desejo de resaltar a partícula "e", a qual simboliza a grande diferença que o eletrônico, melhorado e ampliado tem causado à Ciência nos tempos atuais. Essa característica que faz toda a diferença no contexto de análise.

Atenta-se para a dificuldade formal de se definir o termo $e$-Science, devido a sua precoce vida e falta de consenso na comunidade científica. O melhor caminho para se compreender a definição foi identificar suas origens. Quando mencionado pela primeira vez por John Taylor, este termo foi associado ao reconhecimento do papel cada vez mais importante que a Tecnologia da Informação (TI) representava, no século XXI, para a pesquisa científica intensiva em dados, multidisciplinar e colaborativa. Taylor o designou como o conjunto de ferramentas e tecnologias necessárias para apoiar essa pesquisa (TOLLE et al., 2011).

A inconsistência terminológica do termo $e$-Science está presente na literatura científica e evidencia-se em alguns estudos realizados. Destacam-se dois deles para exemplificar a situação sinalizada e corroborar o que foi pontuado no trabalho de Álvaro e colaboradores (2011, tradução nossa) ao explorarem a compreensão do termo e apresentarem exemplos de trabalhos na literatura relacionados à confusão terminológica existente. Esses autores afirmam que a despeito da variedade de nomes com a qual se denomina a $e$-Science e as questões terminológicas recorrentes, a $e$-Science representa uma grande e significativa mudança.

No trabalho realizado por Gold (2007, [p. 1], tradução nossa), a autora atém-se aos termos e-Science e cyberinfraestructure, mais detidamente ao segundo. Os identifica-os como recorrentes da mesma temática e intercambiáveis, diferen-

2 O Research Councils UK, conforme Vaz (2011, p. 20), "é uma parceria estratégica entre os Conselhos de Pesquisa do Reino Unido criada em 2002 para permitir que eles trabalhem colaborativamente de maneira mais eficaz [...]" 
ciados apenas pela questão geográfica de aplicação. Observa também como a ideia a eles atribuída está no centro das ambições e promessas da Ciência no novo século. A autora manifesta preocupação com os profissionais da informação, especialmente com os bibliotecários que trabalham diretamente com os produtores e usuários dos dados e com os produtos advindos dessa produção. Contribui com uma cartilha para a cyberinfraestrura destinada a bibliotecários e conclui ao pontuar questões como: captura, arquivamento, curadoria, acesso, interoperabilidade, análise, serviços, ciclo de vida, instrumentos políticos e modelos de negócios relacionados aos dados de pesquisa.

No segundo exemplo, representado pelo estudo de Schottlaender (2010, p. 99 , tradução nossa), a questão conceitual dos termos e-Science e cyberinfraestrutura é pontuada. O autor é muito incisivo ao distingui-los terminologicamente e critica o fato desses termos serem considerados intercambiáveis ou carregados do mesmo significado. Salienta que não os define como tal e não fará uso dessa prerrogativa para tratá-los em seu estudo e considera a cyberinfraestrutura como um meio para atingir o fim, que é a e-Science. Para esse autor, esses termos são dependentes, mas não iguais, como destaca em sua assertiva: “[...]' ou seja, cyberinfrastructure é condição para o desenvolvimento e realização da e-Science. Esta última não pode, literalmente, ser realizada sem a primeira; e sem a última, a primeira é menor do que uma solução em busca de um problema."

São posições opostas entre os autores que apresentam os conceitos de e-Science e cyberinfraestrutura e essas representam o quadro indefinido que caracteriza a compreensão da comunidade científica sobre a temática e evidenciam claramente a necessidade de muitos estudos para que uma posição seja contemplada na questão. Somente para ilustrar a situação são apresentados outros termos que se inserem no contexto e representam a questão maior que os congrega, bem como as mudanças ocorridas na prática científica com o uso intensivo dos artefatos tecnológicos.

Esses termos carregam preferências, linhas de pesquisa, objetivos etc, e são identificados como: ciência orientada por dados (data-driven science); computação fortemente orientada por dados (data-intensive computing); mineração de dados (data mining); quarto paradigma (fourth paradigm); dos dados ao conhecimento (from data to knowledge); ciência com uso intensivo de dados (data-intensive science); pesquisa 
eletrônica (e-Research). (CESAR JUNIOR, 2011; JANKWSKI, 2009). Segundo Whitmire (2013, tradução nossa), o termo e-Research, inclusive, no contexto biblioteconômico, foi definido pela Association of Research Libraries (ARL) (2013) como:

uma forma de rede colaborativa, de larga escala e computacionalmente intensiva de pesquisa e de bolsas de estudo para todas as disciplinas, incluindo todas as ciências físicas e naturais, relacionadas e aplicadas às disciplinas tecnológicas, biomédicas, ciências sociais e as humanidades digitais.

Essa definição, segundo Soehner e colaboradores (2010, p. 3), assemelha-se com a que foi atribuída ao termo e-Science pela própria ALA, em 2010, o que reforça a imprecisão terminológica e provoca confusão quanto ao entendimento dos conceitos na área. Fica evidente a necessidade de estudos que indiquem como os pesquisadores das diversas áreas de conhecimento acolhem este conceito, sem descartar, também, a necessidade de um vocabulário que melhor o defina. Contribui-se, desse modo, com construção de um referencial terminológico para a área da Ciência da Informação. Como sinalizado antes, estes termos representam as mudanças em curso na Ciência e resgatam outros mais antigos que foram precussores desse contexto atual como: Big Science, Cyberscience e mais recentemente o Big Data, o Open Data e o Open Science.

Independentemente da terminologia adotada, faz-se necessário registrar que tanto a $e$-Science quanto a cyberinfraestructure foram iniciativas originárias de políticas governamentais, a primeira no Reino Unido e a segunda nos Estados Unidos, com a intenção de fortalecer o desenvolvimento da alta computação e da tecnologia de informação e comunicação (JANKWSKI, 2007).

A e-Science surgiu da necessidade urgente de se enfrentar o "dilúvio de dados", popularizou uma nova metodologia de pesquisa, desenvolvida em diferentes lugares, com uma história ainda imprecisa, denominações e grafias distintas, flexíveis e ainda tênues, mas com o objetivo comum de se usar tecnologias de computação em rede para melhorar a colaboração e os métodos inovadores de investigação (WHITMIRE, 2013). Conforme Levy (1999, p. 13) o termo "segundo dilúvio" das informações foi atribuído a Roy Ascott e ilustra perfeitamente o "dilúvio de dados" tão utilizado atualmente. 
As telecomunicações geram esse novo dilúvio por conta da natureza exponencial, explosiva e caótica de seu crescimento. A quantidade bruta de dados disponíveis se multiplica e se acelera. A densidade dos links entre as informações aumenta vertiginosamente nos bancos de dados, nos hipertextos e nas redes. Os contratos transversais entre os indivíduos proliferam de forma anárquica. É o transbordamento caótico das informações, a inundação de dados, as águas tumultuosas e os turbilhoes da comunicação, a cacofonia e o psitacismo ensurdecedor das mídias, a guerra das imagens, as propagandas e as contrapropagandas, a confusão dos espíritos.

Ao retomar a questão conceitual observa-se que diferentemente do termo e-Science, o qual é relativamente novo, o termo cyberinfrastructure, mais usado nos Estados Unidos, tem mais tempo de aparecimento e seu emprego inicial é atribuído a Richard A. Clarke e Jeffrey Hunkeyr, do National Science Foundation (NSA), em entrevista concedida em 1998, nos Estados Unidos (CLARKE; HUNKER, 1998). Esses termos são identificados como sinônimos, em alguns casos, e se referem ao uso de tecnologias de computação em rede para melhorar a colaboração e os métodos inovadores de investigação, como foi destacado nos exemplos extraídos da literatura científica.

Acredita-se ser mais apropriado observarem-se as colocações e adequá-las entre as várias proposições, de acordo com a realidade de cada país. A Ciência pode atestar conceitos e, por essa razão, definições ou terminologias são importantes. Entretanto, os resultados advindos do fazer científico proporcionarão à sociedade um ganho de maior vulto enquanto a terminologia se define com o amadurecer e aprofundamento da temática e realização de pesquisas. Devido ao pouco tempo de existência da e-Science, ainda decorrerá muito tempo para que esse amadurecimento ocorra.

As características atribuídas aos dois termos atestam que o foco na pesquisa é atribuição da $e$-Science, justamente por ser considerada como finalidade do processo, ao passo que a cyberinfrastructure é mais abrangente e robusta por representar o meio necessário ao processo de construção do conhecimento científico. Inicialmente a $e$-Science foi usada em áreas como as Ciências Naturais e Biológicas, mas atualmente não se restringe apenas a essas. Ambas, 
cyberinfrastructure e e-Science incorporaram maior ênfase nos recursos de supercomputação e inovação devido ao grande volume de dados envolvidos nos esforços de pesquisa.

A e-Science agrega-se à infraestrutura, a qual fornece aos cientistas ferramentas que apresentam um escopo para coletar, armazenar, interpretar e analisar a rede de dados produzida e disseminá-la para outros grupos de trabalho. Conforme Soon e Park ao citar Hine, a e-Science tem sido definida como "usos da infraestrutura de Tecnologia de Informação e Comunicação (TIC) para o armazenamento de dados científicos, análises e realização de trabalho colaborativo, também conhecida nos EUA como as cyberinfraestruturas e no Reino Unido como e-Science." (SOON; PARK, 2009, tradução nossa).

Esse modelo significa o elo entre uma tendência da Ciência para utilização da tecnologia e o compartilhamento de saberes. A prática colaborativa, característica da e-Science, desempenha papel fundamental ao aliar a tecnologia por essa desenvolvida ao movimento do homem em direção à descoberta, intrínseco à sua natureza (E-SCIENCE, 2012b).

A tecnologia, como peça chave no processo, desempenha seu papel, proporciona a operacionalização dos projetos pretendidos e garante a disponibilidade e acessibilidade da informação científica e tecnológica. Considerada por Jim Gray como o quarto paradigma, a $e$-Science pode ainda ser definida como a utilização de ferramentas computacionais para analisar grandes conjuntos de dados científicos (E-SCIENCE, 2012a).

Analisa-se, na próxima seção deste livro, a atual situação relativa à infraestrutura científica, tecnológica e de inovação, em termos de $e$-Science, e espera-se poder associá-la ao contexto brasileiro, representado pelos INCTs da área de Nanotecnologia. Isso configuraria a evidência de que se está caminhando, efetivamente, para o envolvimento real e para a frutífera inserção do Brasil na agenda da $e$-Science mundial.

\section{Modelo de infraestrutura e-Science}

Conceber um modelo que represente a infraestrutura e-Science requer fundamentos que a identifique e permita referência e comparação com outras es- 
truturas. A alocação de recursos e todo arsenal necessário para a sustentação da prática colaborativa contemporânea caracteriza esse tipo de infraestrutura, sobre o qual Albagli e colaboradores (2013, grifo do autor) expõem:

A e-Science supõe a construção de uma infraestrutura informática computacional de uso distribuído, capaz de permitir a colaboração à distância de equipes de pesquisa, envolvendo o uso intensivo e o compartilhamento de dados e recursos computacionais. Essa infraestrutura tecnológica tem sido baseada em Grids, Midleware, Workbenches, Webservices, Virtual Research Environments (VRE), tecnologias de notação e armazenamento de dados concebidas em padrões como XML3, entre outras.

Suposições são indicadas em torno da concepção de uma infraestrutura e-Science e, conforme Andronico e colaboradores (2011, p. 156, tradução nossa), atualmente ela é denominada como e-infraestructure, ou seja, "um 'método científico' que prevê a adoção de plataformas digitais de ponta conhecidas como infraestruturas eletrônicas em todo o processo da ideia à produção do resultado científico." Segundo os autores citados esta infraestrutura eletrônica pode ser conceitualmente representada por três camadas:

- parte inferior, composta pelos instrumentos científicos e experimentos que fornecem grande quantidade de dados;

- em seguida, a camada de rede, centros de processamento de dados em rede e software middleware como a "cola" dos recursos; e

- o terceiro e mais alto nível que inclui pesquisadores que realizam suas atividades independente da localização geográfica, interagem com os colegas, compartilham e acessam os dados.

A definição de infraestrutura e-Science anteriormente apresentada possui consonância com a suposição de Albagli e colaboradores (2013). A seguir, apresenta-se um modelo de infraestrutura $e$-Science baseado nos elementos obtidos e compilados, na Figura 2. 
Figura 2 - Modelo de Infraestrutura e-Science

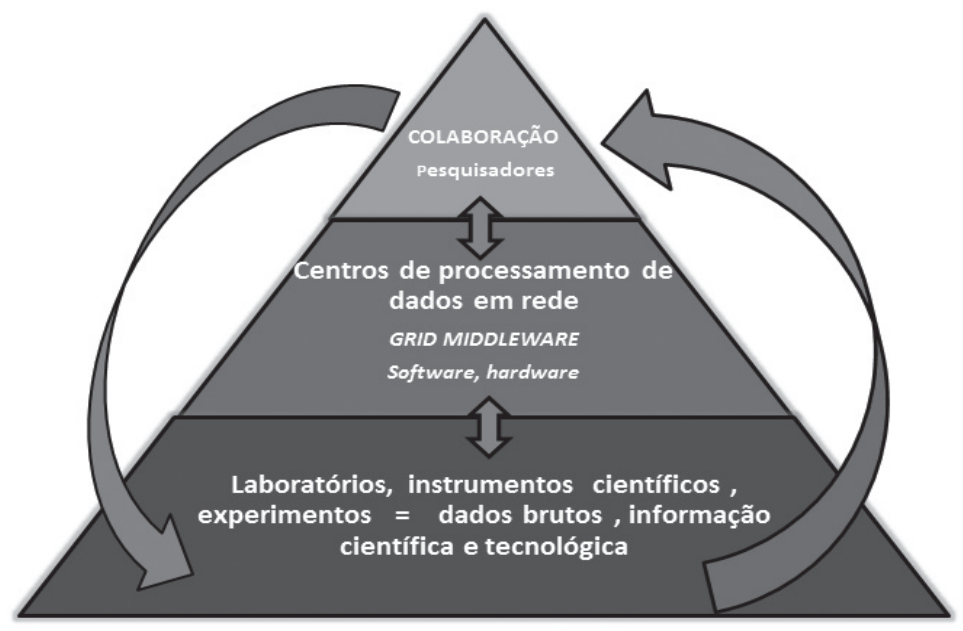

Fonte: Elaboração da autora baseada em Andronico e colaboradores (2011).

As práticas colaborativas contemporâneas, especialmente as realizadas nos domínios de ponta, necessitam de uma infraestrutura potente a qual permita o fluxo rápido e eficiente dos dados em constante transmissão. Essa infraestrutura "requer um ambiente para o desenvolvimento eficiente de novos programas e recursos para rapidamente compartilhar os programas entre os membros dentro de uma comunidade de pesquisa." (USAMI et al., 2011, p. 851, tradução nossa).

Neste cenário, a infraestrutura agregada à e-Science tornou-se a base em torno da qual os cientistas e tecnólogos estão trabalhando para alcançar novas descobertas e avanços para melhorar áreas nos diversos campos do conhecimento e desenvolver alternativas para lidar com a enorme quantidade de dados produzidos. Entretanto, Hey e Hey (2006, p. 517, tradução nossa) enfatizam que:

é importante ressaltar que a e-Science não é uma nova disciplina científica, em seu próprio direito: a e-Science é um atalho para o conjunto de ferramentas e tecnologias necessárias para apoiar a ciência, colaborativa em rede. Toda infraestrutura da $e$-Science se destina a capacitar os cientistas a fazer suas pesquisas de forma mais rápida, melhor e diferente. 
A estrutura de rede, um elemento indissociável do pensamento contemporâneo, foi reconhecida por Roure e Hendler (2004) como a infraestrutura da e-Science. Eles salientam que também a gestão de informação, e não apenas de computação de alto desempenho ou instrumentação científica especializada, seria necessária para cumprir as metas de um programa com a amplitude que os programas de $e$-Science demandam.

Uma plataforma $e$-Science está cercada de um conjunto de elementos que viabilizam sua execução. Leva-se em consideração tanto os recursos computacionais, compostos por todo arcabouço tecnológico cercado pelo hardware, software e redes que suportam e gerenciam os dados produzidos quanto pelo capital humano com toda sua expertise e saber, e as instituições que fomentam e são responsáveis pelo abrigo e manutenção de toda infraestrutura envolvida.

Conforme Hey e Trefethen (2006) o termo "Grid" foi usado pela primeira vez em meados da década de 1990 para designar uma infraestrutura de computação distribuída para a ciência e engenharia avançada. Essa infraestrutura ocupava-se tanto do hardware como do software para apoiar os principais passos tipicamente envolvidos de captura, armazenamento, manutenção, análise e visualização dos dados, utilizando-se, desse modo, dos esforços dessa computação em grade, realizada quando uma rede permite que os recursos de cada computador sejam compartilhados com toda e qualquer máquina do sistema (CESAR JUNIOR, 2011; E-SCIENCE, 2012b).

Ao configurar-se como elo entre uma poderosa tendência da Ciência - o compartilhamento de saberes e fazeres e a infraestrutura fornecida pela Ciência da Computação - a e-Science alia o movimento do homem em direção à descoberta, intrínseco à sua natureza, à tecnologia por ele desenvolvida. O registro recente dessa metodologia, de aproximadamente 16 anos, e uma história em construção desafiam o pesquisador a conhecê-la melhor e a buscar referências mais precisas sobre seu aparecimento, definindo uma agenda motivadora e instigante para a pesquisa.

Segundo Jim Gray, a e-Science é o ponto onde a TI encontra cientistas (GRAY; SZALAY, 2007). A tecnologia, como peça chave no processo, desempenha seu papel ao proporcionar a operacionalização dos projetos pretendidos e ao garantir a disponibilidade e acessibilidade da informação científica e dos dados 
primários produzidos com a captura, curadoria e análise. O tratamento desses insumos com a interveniência dos recursos tecnológicos da infraestrutura e-Science é ansiada por Bell (2011, p. 12), o qual acredita "que logo mais chegará um tempo em que os dados viverão para sempre em mídia arquivada - igualzinho ao armazenamento em papel - e será acessível publicamente a homens e máquinas numa nuvem". Descrita também como o quarto paradigma, conforme indicado anteriormente, a infraestrutura que compõe a $e$-Science pode ainda ser definida como as ferramentas computacionais utilizadas para analisar grandes conjuntos de dados científicos aliados à colaboração impulsionada pelos pesquisadores. Conforme Mundie (2011, p. 232),

Essa infraestrutura de computação aperfeiçoada tornará possível a verdadeira biblioteca digital global, onde todo o ciclo de vida da pesquisa acadêmica - da formulação à publicação - terá lugar num ambiente eletrônico e estável disponível para todos, de forma aberta. Durante o desenvolvimento das ideias científicas e sua publicação subsequente, os cientistas poderão interagir entre si virtualmente - compartilhando dados, fluxos de trabalho e pesquisa.

Ao resgatar a palestra que foi proferida por Jim Gray, em 11 de janeiro de 2007, no National Research Council/Computer Science and Telecommunications Board, (NRC-CSTB), na qual ele expande sua visão da Ciência com uso intensivo de dados, Tolle e colaboradores (2011, p. 235) apresentam as sete áreas-chave indicadas por Gray para ação a serem consideradas pelas agências de fomento. São elas:

- estimular tanto o desenvolvimento de ferramentas de software como o apoio a essas ferramentas;

- investir em ferramentas em todos os níveis da pirâmide de recursos;

- estimular o desenvolvimento de Sistemas de Gerenciamento de Informações Laboratoriais (SGIL) genéricos;

- estimular pesquisa nas áreas de gerenciamento de dados científicos, análise de dados, visualização de dados e novos algoritmos e ferramentas;

- estabelecer bibliotecas digitais para apoiar outras ciências, assim como a Biblioteca Nacional de Medicina apoia as Biociências; 
- estimular o desenvolvimento de novos modelos de publicação e novas ferramentas de autoria de documentos;

- estimular o desenvolvimento de bibliotecas digitais de dados que contenham dados científicos (não apenas metadados) e apoiem a integração com a literatura publicada (TOLLE et al., 2011, p. 235).

Existem muitas iniciativas de projetos e-Science distribuídas no mundo inteiro e fomentados por agências internacionais e conselhos que se encarregam da manutenção e suporte para o desenvolvimento efetivo. Destacam-se programas financiados pela National Science Foundation (NSF), nos Estados Unidos e os Research Councils UK (RCUK), no Reino Unido, cujas iniciativas na área datam dos anos 2000. Os centros de e-Science na Holanda, Suécia e Austrália são outros exemplos internacionais nas mais variadas áreas de conhecimento (FUNDAÇÃO DE AMPARO À PESQUISA DO ESTADO DE SÃO PAULO, 2015).

A Amazon, ${ }^{3}$ o Disc, ${ }^{4}$ o MapReduce ${ }^{5}$ do Google, o Hadoop ${ }^{6}$ e o Dryad ${ }^{7}$ são exemplos de infraestruturas emergentes de computação em nuvem e plataformas de computação de nova geração que estão voltadas para o gerenciamento e processamento de grandes volumes de dados. Parastatidis (2011, p. 176, grifo do autor) acrescenta que:

empresas como o Google, o Yahoo e a Microsoft estão demonstrando que é possível agregar enormes volumes de dados de toda parte na web e armazená-los, gerencia-lós e indexá-los, para depois construir experiências atraentes para os usuários em torno disso tudo.

3 A Amazon oferece serviços de infraestrutura de nuvem abrangentes e altamente especializados. Disponível em: <http://aws.amazon.com>.

4 Data-Intensive Super Computing (DISC). Disponível em: <www.pdl.cmu.edu/DISC>.

5 MapReduce "é um modelo de programação e aplicações associadas para processamento e geração de grandes conjuntos de dados" (DEAN; GHEMAWAT, 2004, p. 1). Disponível em: $<$ http://labs.google.com/papers/mapreduce.html>.

6 Hadoop é uma plataforma de software, em Java, de computação distribuída voltada para clusters e grandes conjuntos de dados. Disponível em: <hadoop.apache.org>.

7 Dryad é uma infraestrutura que permite que um programador use os recursos de um cluster de computadores ou de um centro de dados para a execução de programas de dados paralelos.(MICROSOFT, 2016). Disponível em: <https://www.microsoft.com/en-us/research/ project/dryad/>. 
Essas iniciativas em e-Science são investimentos para a construção de ambientes favoráveis e que deem sustentação às atribuições que uma infraestrutura desse porte carrega. Além das iniciativas sinalizadas, inserem-se as do Japão nesse contexto de implementações. Apresenta-se, como exemplo, a iniciativa japonesa descrita por Usami e colaboradores (2011, p. 849, tradução nossa), o Projeto REsources liNKage for E-sclence (RENKEI), sucessor do projeto National Research Grid Initiative (NAREGI). A principal atividade desenvolvida pelo grupo que compõe o projeto foi estender a rede middlewary NAREGI com a intenção de oferecer suporte em diferentes ambientes de rede. As especificidades desse projeto foram destacadas a seguir:

O RENKEI é um esforço para desenvolver um ambiente de software onde os pesquisadores podem criar e operar facilmente em comunidades em vários ambientes de rede. Especificamente nós estamos realizando desenvolvimento e pesquisa de grade middleware para utilizar o poder de computação federada, arquivos, bancos de dados etc., a partir de ambientes de rede diferentes, de ambientes de rede de nível laboratório de pequena escala, para ambiente de grade de nível central em supercomputador de larga escala e outros ambientes de rede de países estrangeiros (USAMI et al., 2011).

Uma representação da estrutura que compõe o projeto RENKEI e a relação entre os grupos que o compõem foi apresentada na Figura 3.

Os grupos do RENKEI que desenvolvem atividades de $\mathrm{P} \& \mathrm{D}$ foram identificados conforme Usami e colaboradores (2011, p. 849, tradução nossa), da seguinte forma:

- federação de recursos de computação e aplicações de hospedagem de Organizações Virtuais;

- compartilhamento de arquivos e federação de catalogação de arquivos;

- federação de Bases de Dados e sistemas de gerenciamento de ID;

- API para várias grades middleware;

- avaliação e colaboração com os usuários. 
Figura 3 - Projeto RENKEI - Suporte para ambientes de rede

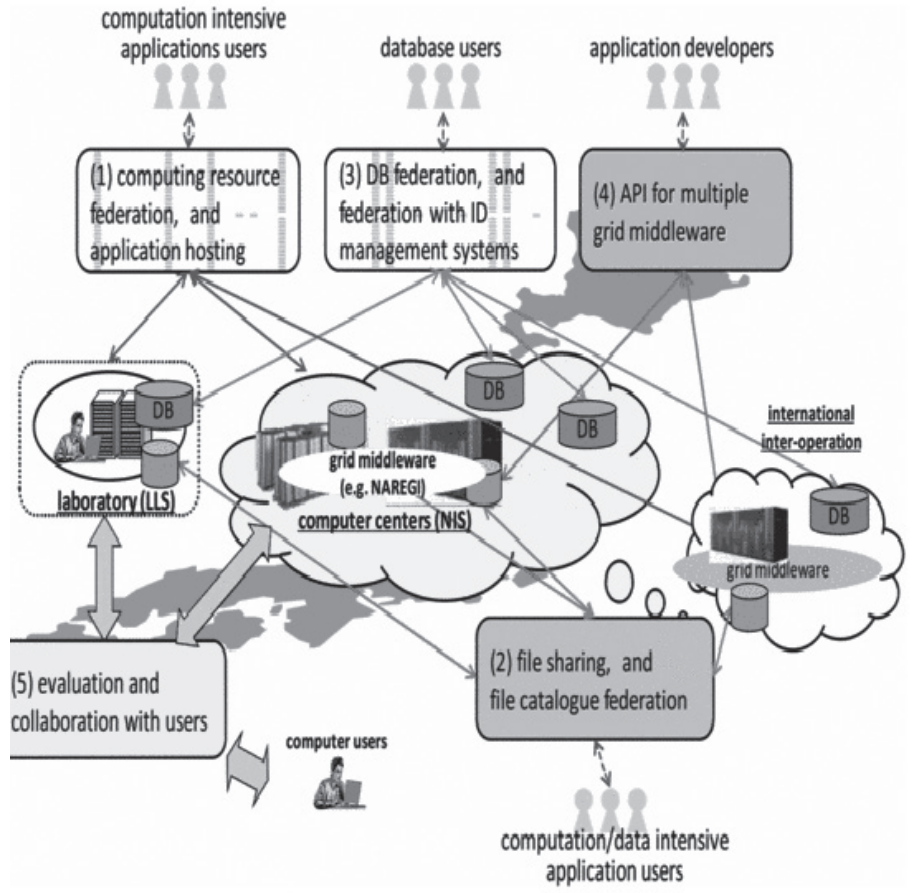

Fonte: Usami e colaboradores (2011, p. 850).

Iniciativas desse porte evidenciam que se faz necessário, na esfera nacional, projetos que estejam voltados para uma infraestrutura complexa que suporte as novas formas do fazer científico, com os compartilhamentos dos dados empíricos produzidos e a colaboração entre os pesquisadores das diversas áreas do conhecimento. Conforme Vaz (2011, p. 11), "no Brasil, mais de uma década depois do início do programa do Reino Unido, há poucos cientistas que têm conhecimento ou interesse sobre o tema e tampouco há um programa nacional integrado".

Contudo, os pesquisadores brasileiros, concentrados em São Paulo, começam a perceber a necessidade de engajamento nesse contexto e começam a intensificar os estudos e aplicações nesta temática. Atenta a essa necessidade e em parceria com a Ciência da Computação e Engenharia (CS\&E), a Fundação de Amparo à 
Pesquisa do Estado de São Paulo (FAPESP) organizou duas oficinas com as metas identificadas como G1 e G2, em agosto e novembro de 2009.

G1) para identificar novos rumos na Ciência da Computação (CS) para avançar a pesquisa na área, no estado de SP, e mecanismos para implementar iniciativas relacionadas;

G2) para investigar como essas instruções poderão, ao mesmo tempo ajudar no avanço de outros programas relevantes da FAPESP, com relevantes, com oportunidades de colaboração de pesquisa identificáveis com CS (FUNDAÇÃO DE AMPARO À PESQUISA DO ESTADO DE SÃO PAULO, 2014, tradução nossa).

As oficinas representaram os primeiros movimentos em busca da inserção da temática e-Science entre os pesquisadores de diversos domínios do conhecimento, localizados no estado de São Paulo, nas quais se realizaram discussões iniciais em torno de um esforço colaborativo para se buscar alternativas que levassem ao alcance das metas G1 e G2. Fizeram parte do grupo pesquisadores da área de computação e de outros domínios do conhecimento, os quais desenvolveram projetos nas áreas da "medicina, bioenergia, mudanças climáticas, biodiversidade, astronomia, física de partículas, desenvolvimento urbano e bibliotecas digitais (Brasiliana).” Esses pesquisadores concluíram pela relevância da temática, que essa poderia proporcionar ganhos para a pesquisa nos diversos domínios (FUNDAÇÃO DE AMPARO À PESQUISA DO ESTADO DE SÃO PAULO, 2014).

Em continuidade à sua ação, a FAPESP realizou o Latin American e-Science Workshop 2013, em maio de 2013, seminário que buscou reunir estudantes e pesquisadores da Europa, América do Sul e do Norte e da Oceania para discutir e apresentar as implementações nessa área (FUNDAÇÃO DE AMPARO À PESQUISA DO ESTADO DE SÃO PAULO, 2013).

Ainda em 2013, a FAPESP criou o Programa FAPESP de Pesquisa em eScience. "O principal objetivo do programa era encorajar abordagens novas, ousadas e não convencionais para pesquisa de ponta, multidisciplinar, integrando grupos de pesquisa em Computação e em outras áreas.” (FUNDAÇÃO DE AMPARO À PESQUISA DO ESTADO DE SÃO PAULO, 2015). 
O primeiro edital da FAPESP a contemplar projetos em e-Science foi lançado em dezembro de 2013. Para isso, realizou o investimento de $\mathrm{R} \$ 4$ milhões e promoveu o apoio a projetos nas seguintes áreas: "Ciências Agrárias; Artes, Humanidades e Ciências Sociais; Bioinformática; Ciências Biológicas e Ciências da Saúde; Engenharia e Física; Clima e Ciências da Terra; e prática e educação em eScience." (FUNDAÇÃO DE AMPARO À PESQUISA DO ESTADO DE SÃO PAULO, 2015).

A primeira seleção do programa contemplou quatro projetos em pesquisas espaciais, agropecuária, arqueologia e engenharia. A característica do fomento ateve-se a Projetos Temáticos com pesquisadores de uma ou mais instituições, com duração de 60 meses, ou Auxílio Regular à Pesquisa, projeto individual, com duração de 24 meses. A contratação de profissionais da área de Computação é a contrapartida institucional do Programa eScience, em que se insere como exigência a política de gestão de dados, com as especificidades que a cercam. Em 2015, lançou-se nova chamada para propostas ao Programa eScience da FAPESP (FUNDAÇÃO DE AMPARO À PESQUISA DO ESTADO DE SÃO PAULO, 2015).

Outras iniciativas identificadas são as realizadas pelo Núcleo de Pesquisa em e-Science da Universidade de São Paulo (NAP-USP), responsável pelo projeto scriptLattes. ${ }^{8}$ A Biblioteca de dados Geoespaciais ${ }^{9}$ da Empresa Brasileira de Pesquisa Agropecuária (Embrapa) lançou um sistema de armazenamento e consulta de conteúdo geoespacial, o qual busca ajudar a tornar menos árdua a tarefa de implementação dessa prática no Brasil. Essas iniciativas são muito bem vindas e um mapeamento mais apurado permitiria identificá-las e ampliar sua divulgação (BIBLIOTECA, 2013).

Identifica-se, nas iniciativas pautadas, a intenção de associar pesquisas sobre infraestrutura de informação e os seus respectivos domínios. Percebe-se que a busca por um melhor entendimento sobre esse conceito é latente e a associação

8 scriptlattes é um sistema de código aberto que foi desenvolvido para a compilação automática de dados referentes a produções bibliográficas, técnicas, artísticas, de orientações, projetos de pesquisa, prêmios e títulos, grafo de colaborações, mapa de geolocalização, coautoria e internacionalização de um conjunto de pesquisadores cadastrados na Plataforma Lattes (MENA-CHALCO; CESAR JUNIOR, 2009).

9 O acesso à Biblioteca de dados Geoespaciais pode ser realizado pelo endereço eletrônico: <http://geo.cnpma.embrapa.br>. 
da e-Science a área da Nanotecnologia é recorrente. Em relatório realizado pela Lloyd's Register Foundation (LR) em 2004, encontra-se a indicação de que a Nanotecnologia terá um grande impacto sobre quase todos os setores incluindo, energia, transporte, fabricação, medicina, tecnologia da informação e telecomunicações. Sua associação com os Big Data é frequente ao passo dessa parceria ser denominada como como a próxima revolução digital (RODRIGUEZ, 2015).

A associação entre pesquisas sobre infraestrutura de informação e os respectivos domínios cobertos pela e-Science, práticas colaborativas e políticas de fomento são pertinentes. Observa-se neste conjunto que a e-Science é considerada a "base para a pesquisa colaborativa e em rede" (IZIQUE, 2013, p. 2), um elemento importante para a realização do "experimento" que se define como fazer científico contemporâneo. $\mathrm{O}$ entendimento da construção desse fazer permite um trânsito seguro sobre seus domínios e uma preocupação nos capítulos seguintes. 


\title{
POLÍTICAS PÚBLICAS PARA FOMENTO CIENTÍFICO, TECNOLÓGICO E DE INOVAÇÃO
}

\begin{abstract}
A nave espacial Terra é movida por quatro motores associados e, ao mesmo tempo, descontrolados: ciência, técnica, indústria e capitalismo (lucro). O problema está em estabelecer um controle sobre estes motores: os poderes da ciência, da técnica e da indústria devem ser controlados pela ética, que só pode impor seu controle por meio da política.
\end{abstract}

(MORIN, 2002)

O fluxo de conhecimento entre a academia e a indústria não pode se tornar uma via de mão única. Esta observação é salientada por Povoa (2008, p. 19) ao afirmar que "a existência de uma complexa relação interativa entre ciência e tecnologia faz com que o fluxo de conhecimento entre a academia e a indústria não seja uma via de sentido único". Esse autor destaca ainda a atuação de atores como universidade, institutos de pesquisa, indústria e as agências de fomento, as últimas representadas pelo sistema nacional de inovação, o que reforça a pertinência dos elementos que estruturam esse livro.

Decisões políticas são tomadas com base em avaliações que a comunidade cientifica realiza sobre a dinâmica da produção científica e tecnológica dos pesquisadores das instituições de pesquisa, universidades e empresas. O interesse por assuntos que contemplam aspectos como produtividade, qualidade da pesquisa e colaboração em CT\&I são correntemente considerados (MARICATO, 2010). 
Ao se fazer um resgate do cenário histórico e político brasileiro, especialmente a partir do século XIX, são evidenciados os primórdios do binômio C\&T com as atividades na "agricultura e mineração que receberam incentivos para a inovação e o desenvolvimento tecnológico, principalmente com o fim da escravidão em 1889." (LEMOS; CÁRIO, 2013, p. 2). A produção de trabalhos científicos e tecnológicos expressivos pode ser constatada nos trabalhos realizados por cientistas como Adolfo Lutz, Oswaldo Cruz, Roberto Landell de Moura, Vital Brazil, Alberto Santos Dumont entre outros. A Ciência brasileira "foi marcada por um crescimento lento até os anos 1980, o quadro passa a evoluir rapidamente na última década do século XX e se acelera na primeira década do século XXI." (SOCIEDADE BRASILEIRA PARA O PROGRESSO DA CIÊNCIA, 2011, p. 54).

A explicitação do componente inovação, na primeira metade do século XXI, foi um ponto marcante para as agendas estratégicas de política em C\&T, ao ponto de redefini-las como política de Ciência, Tecnologia e Inovação (CT\&I). A ação coordenada de vários atores favorece a criação da inovação e permite a formação de uma cadeia de conhecimentos. Esta temática foi introduzida no centro dos debates na área, durante a II Conferência Nacional de Ciência Tecnologia e Inovação, em 2001, mas ela estava presente em todas as experiências de reforma na década anterior. Este tripé trouxe, como força propulsora, a necessidade de expandir as fronteiras do conhecimento, agregar novidades e assegurar seu impacto na melhoria de qualidade de vida da sociedade moderna (BALBACHEVSKY, 2010; BORGES, 2011; CENTRO DE GESTÃO E ESTUDOS ESTRATÉGICOS, 2008).

O conhecimento científico é reconhecido como um vetor estratégico para a solução dos grandes problemas do mundo contemporâneo como fome, meio ambiente, energia, entre outros. Nas últimas décadas, a produção desse conhecimento no Brasil foi positiva, de acordo com os indicadores publicados pelos agentes financiadores. O que infelizmente ainda não se pode dizer dos resultados advindos da transformação dessa ciência em desenvolvimento tecnológico e inovação. Uma política de CT\&I robusta potencializará a combinação entre o conhecimento científico, tecnológico e os insumos criados pela inovação, por isso, salienta-se que essa combinação ainda precisa avançar muito. 
Os atores envolvidos nesta combinação, como as universidades e instituições de pesquisa, acolhem a Ciência ao realizarem suas práticas, ao refutarem e/ou corroborarem os pressupostos vigentes. Sem um espaço que delimite seu desenvolvimento, a técnica ocorre à medida que surgem problemas práticos que demandam resolução com motivações diversas. Como um privilégio do mundo moderno é apresentada a inovação, na medida em que se liga com o regime capitalista corrente. Ciència, Tecnologia e Inovação caracterizam um tripé próximo mas com atividades que os distingue e delimita sua atuação (SANTOS JÚNIOR, 2011).

\section{Ciência, tecnologia e inovação: um tripé de peso}

A Ciência, a Tecnologia e a Inovação, segundo Viotti e Macedo (2003, p. 45), "são elementos-chave para o crescimento, a competitividade e o desenvolvimento de empresas, indústrias, regiões e países". Por esse motivo, a busca pela compreensão e monitoramento dos processos de produção, difusão e uso de conhecimentos científicos, tecnológicos e de inovação é uma tarefa que se impõe.

As palavras ciência e tecnologia carregam concepções conceituais que as caracterizam e definem de acordo com o significado e contexto empregado. Em linhas gerais, a palavra ciência é utilizada como sinônimo de saber, conhecimento ou informação e originou-se do termo em latim scientia, o qual significa saber, conhecer, informar. Contudo, em um sentido mais restrito, refere-se a uma forma especial de conhecimento, o conhecimento científico, em contraposição a outras formas existentes (BARBIERI, 1990; CUNHA, 2012).

A palavra tecnologia tem origem no termo grego thecné; na literatura não filosófica da Grécia antiga, referia-se à esperteza, astúcia no fazer, bem como habilidade nas artes e produções. De modo geral, desde o início foi associada, ao termo latino ars artis, que significava um conjunto de regras capaz de dirigir uma atividade humana qualquer. A técnica não fazia distinção com a arte, com a ciência, nem com outro processo ou operação capaz de produzir um efeito qualquer. Em um sentido menos abrangente, significava técnica no sentido de uma arte, habilidade ou ofício, mas não uma habilidade qualquer e, sim, aquela que segue certas regras (ABBAGNANO, 2007; MORAIS, 1988; OLIVEIRA, 2010). 
O termo inovação conforme Cunha (2011, p. 453), vem do latim innnovãre, nova, novidade, conceito que adquiriu um significado e utilização de modo acentuado ao agregar-se aos termos ciência e tecnologia. Segundo Silva e Bignetti (2012, p. 2),

o conceito e as práticas de inovação têm se expandido de forma acelerada. Não apenas o termo inovação adquiriu novos significados como, também, o seu desenvolvimento e a sua aplicação ultrapassaram as fronteiras da empresa e, até, das nações.

No contexto contemporâneo, no qual predominam atividades como, parcerias entre universidade e empresa, propriedade intelectual e transferência tecnológica, o termo inovação foi inserido em uma agenda, em que a capacidade de inovar era considerada uma das mais importantes características das organizações competitivas e que buscavam obter resultados e expansão.

A Ciência se desenvolveu calcada nas diversas teorias, paradigmas e hipóteses que emergiram e/ou foram substituídos durante seu processo de produção. A refutação e/ou corroboração dos pressupostos que a fundamenta sempre fizeram parte de seu percurso de crescimento e solidificação. Conforme Silva (2002a, p. 1), "em ciência, as respostas raramente são definitivas, mas as perguntas perduram”. A Ciência se alimenta das inquietações e questionamentos oriundos da sociedade humana, procura responder 'o porquê' e não se contenta em perceber apenas o 'como' das questões. O 'porquê' caracteriza e representa problemas, objetos e recortes das disciplinas e/ou assuntos que constituem o locus em que está inserida a problemática.

Em seus primórdios, a Ciência tinha como objetivo principal entender especialmente os fenômenos da natureza e as necessidades que emanavam do homem. Com o passar do tempo, caracterizou-se tanto pela tentativa do homem em entender e explicar racionalmente a natureza quanto por formular leis que permitissem, em última instância, sua ação. Em razão das limitações existentes e peculiares ao seu início, a atividade científica era desenvolvida de modo lento e seus pesquisadores possuíam uma atuação isolada (ANDERY et al., 2003; MEADOWS, 1999; MORAIS, 1988; POPPER, 2006; REZENDE, 2010). 
Nos primórdios, "os rudimentos de tecnologia surgem como as primeiras ferramentas, manipuladas a partir do ferro e do cobre. Tais ferramentas aumentavam a probabilidade de sobrevivência em uma natureza altamente hostil." (MEDEIROS, 2012, p. 44). Contudo, já incluía um aspecto teórico em seu sentido, por ser usada para indicar capacidade de se justificar certo procedimento, isto é, o porquê da eficiência de determinado procedimento.

Com raízes na idade antiga, a Ciência como a atividade que conhecemos hoje, a partir da época do Renascimento na Europa começou a ter nova forma e desenhar uma Ciência moderna. A discussão acerca da controversa relação entre a Ciência e a Tecnologia abarca correntes com posicionamentos que as visualizam em alguns momentos unidas e originárias de uma mesma matriz histórica e em outros como desdobramentos uma da outra. Entretanto, é inegável que na revolução galileica, ${ }^{1}$ a Ciência e a Técnica conseguiram unir-se, pelo menos na visão da corrente hegemônica da maioria dos historiadores que interpretavam o surgimento da tecnologia como um desdobramento da Ciência moderna. Isso foi decisivo para o início da Ciência aplicada, da maneira como é entendida na atualidade (MORAIS, 1988; OLIVEIRA, 2010).

A Tecnologia era calcada apenas em bases empíricas e desenvolvida por meio de tentativas, o desenvolvimento da Ciência moderna veio lhe trazer bases sólidas e um campo de observação de fenômenos muito mais vasto. A concepção da inter-relação entre Ciência e Tecnologia somente nos últimos $100 \mathrm{a}$ 200 anos veio a ser percebida de fato (REZENDE, 2010). Saberes de importância fundamental "na decisão dos estilos de vida, da educação, de cultura, em suma de uma concepção de mundo" é o que Apaza Yanarico (2011, p. 99) considera a Ciência e a Tecnologia, ou a Tecnociência.

A socialização exigida pela Ciência, a transforma em um produto consciente da humanidade com uma execução rotineira e colaborativa. A abrangência desse campo do conhecimento abarca uma gama de expressões, instrumentos,

1 Revolução galileica - revolução atribuída ao físico Galileu Galilei (1564-1642) e considerada como o momento simbólico do nascimento do experimentalismo científico. Em 1590, Galileu resolve pôr a prova os ensinamentos de Aristóteles, baseado na premissa de que um pensamento pode ser perfeitamente lógico e enquadrado no bom senso, sem que necessariamente seja verdadeiro. Ele propôs que valorizássemos os sentidos, utilizássemos nossos recursos físicos como meios autênticos de veiculação do conhecimento e, desse modo, ele ultrapassou os limites da Ciência transformando-se em uma nova atitude perante a verdade (MORAIS, 1988). 
pessoas, instituições e “coisas” que são intrínsecas ao seu fazer. A literatura sobre a Ciência é muito fértil e, como o próprio Latour (1997, p. 19) qualifica, chega a ser "gigantesca". Um trecho do pensamento de Ziman sobre a Ciência resgata a essência e fundamentos sob os quais ela está assentada. Uma declaração coerente e atual como se constata na citação a seguir.

A Ciência é uma parte importante do acervo de nossas mentes; seus produtos formam os acessórios à nossa volta [...]. A Ciência é, inegavelmente, um produto consciente da humanidade, com suas origens históricas bem documentadas, um escopo e um conteúdo bem definidos; além do mais, conta com praticantes e expoentes reconhecidamente profissionais. [...] A Ciência [...] é precisa, metódica, acadêmica, lógica e prática. [...] Ciência não significa simplesmente conhecimentos ou informações publicados. [...] O conhecimento científico é mais do que isso. Seus fatos e teorias têm de passar por um crivo, por uma fase de análises, críticas e de provas, realizadas por outros indivíduos competentes e desinteressados, os quais deverão determinar se eles são bastante convincentes para que possam ser universalmente aceitos. O objetivo da Ciência não é apenas adquirir informação, nem enunciar postulados indiscutíveis, sua meta é alcançar um consenso de opinião racional que abranja o mais vasto campo possível (ZIMAN, 1979, p. 17-24).

O papel desempenhado pela tecnologia na concepção de Kuhn (2011, p. 36) é considerado vital para o surgimento "de novas ciências, já que os ofícios são uma fonte facilmente acessível de fatos que não poderiam ter sido descobertos casualmente."

A compreensão da natureza da Ciência e da Tecnologia sempre demandou uma observação apurada do comportamento dos seus atores e da atividade em torno da qual eles empreendem seus esforços, a prática científica e tecnológica. A comunidade científica constrói o conhecimento científico e devolve-o à sociedade como uma resposta aos questionamentos dessa oriundos. Neste ambiente, o processo de produção do conhecimento acontece e é retroalimentado, transformando e sendo transformado, afetando a sociedade na mesma medida em que é por ela afetado. A pesquisa científica como salienta Ziman (1979, p. 25) "é 
uma atividade social. [...] Para bem compreendermos a natureza da Ciência precisamos observar a maneira como os cientistas se comportam uns com os outros, como se organizam e como transmitem as informações entre si." Com um olhar crítico e inovador, Latour (2012, p. 31, grifo do autor) reforça essa assertiva e renova a necessidade de seguir os atores do processo ao dizer:

[...] cumpre 'seguir os próprios atores', ou seja, tentar entender suas inovações frequentemente bizarras, a fim de descobrir o que a existência coletiva se tornou em suas mãos, que métodos elaboraram para sua adequação, quais definições esclareciam melhor as novas associações que eles se viram forçados a estabelecer.

O entrelaçamento dos atores com as coisas tornou-se o fio condutor dessa visão renovada de Ciência e Tecnologia e conforme indica Souza e Sales Júnior (2012, p. 14) "seguir os atores nesse caso é segui-los em seu entrelaçamento com as coisas, pois sim as coisas também agem, elas podem autorizar, permitir, proporcionar, encorajar, sugerir, influenciar, bloquear, dificultar etc."

A passagem do tempo evidencia as mudanças ocorridas na sociedade e seus desdobramentos na política, economia e cultura. Nesse contexto, e especialmente na economia do conhecimento, identificam-se os agentes do processo de construção do conhecimento e as transformações por que passaram e passam tais como: as ferramentas, tecnologias e artefatos utilizados e produzidos; o tratamento dos dados brutos e da informação científica e tecnológica; a prática colaborativa; a comunicação e divulgação científica; as formas de publicação e avaliação; o reuso; a captura; a curadoria; e análise desses produtos; enfim, as "coisas" que se entrelaçam com os atores e que também se transformam em atores, ou melhor, em actantes ${ }^{2}$ e culminam com a transformação da sociedade em um coletivo que a todos agrega.

A criação das primeiras instituições de caráter técnico e científico no Brasil ocorreu a partir de 1808, com a instalação da Família Real Portuguesa no país (LEMOS; CÁRIO, 2013). O papel das instituições universitárias, institutos e centros de pesquisa foram de fundamental importância para o preparo de

2 No "inglês, a palavra 'actor' (ator) se limita a humanos, utilizamos muitas vezes 'actante' (atuante), termo tomado da semiótica, para incluir não humanos na definição." (LATOUR, 2001, p. 346). 
um ambiente propício ao nascimento da Ciência brasileira e ao surgimento da pesquisa tecnológica no país. Rezende (2010, p. 13) destaca esse momento ao relatar que:

O desenvolvimento da Ciência e Tecnologia no Brasil exigiu a criação de um amplo conjunto de instituições e de um novo estatuto para o ensino universitário. Foi necessário construir órgãos federais e estaduais voltados para o financiamento da pesquisa; foi reformado o regime de trabalho nas universidades, incorporando o tempo integral para os docentes; foram constituídas muitas universidades e centros de pesquisa; foi gradualmente afirmando-se uma cultura que incorporava a Ciência e a Tecnologia como instrumentos na agenda das políticas públicas, tornando esse binômio partícipe no enfrentamento das questões sociais do país.

O mundo ficou mais alerta para questões como segurança, economia e saúde tornando-se um solo frutífero para o desenvolvimento de pesquisas científicas e tecnológicas depois dos reflexos do pós-segunda-guerra. O despertar para a real importância da Ciência e Tecnologia (C\&T), no Brasil, é recente para um país que busca o desenvolvimento social e econômico da sua sociedade. A implementação de políticas para este fim é uma necessidade latente.

O desejo de inserção entre as grandes potências mundiais, além da diminuição da dependência, tecnológica impulsionou a compreensão de que C\&T são motores para o crescimento, competitividade e desenvolvimento de um país. Para a conquista desses indicadores, a inserção da C\&T em sua agenda política tornou-se imprescindível. "A base científica e tecnológica do país precisa ser ampliada, sobretudo para impulsionar a competitividade das empresas brasileiras e contribuir para a criação de um parque industrial sólido nos setores de alta e média-alta intensidade tecnológica ${ }^{3}$ (SOCIEDADE BRASILEIRA PARA O PROGRESSO DA CIÊNCIA, 2011).

O momento seguinte à segunda guerra mundial foi marcante, especialmente para o conjunto de inovações tecnológicas que tiveram como exponenciais

3 Classificação da Organisation for Economic Co-operation and Development (OCDE ) (OCDE, 2009). 
as tecnologias de informação e comunicação. O exame das questões que envolveram essas mudanças pode ser realizado utilizando-se óticas distintas, as quais podem ser identificadas como correntes teóricas que fundamentaram e construíram o alicerce para as análises realizadas. Recorrendo aos fundamentos construídos pelos "gigantes" predecessores, os teóricos contemporâneos que representam estas correntes nem sempre hegemônicas, defenderam pressupostos que em alguns aspectos possuíam interseções em alguns aspectos, mas que eram diametralmente opostos em outros.

No conjunto que representa essas correntes de pensamento estão inseridos autores como Manuel Castells, Michel Foucault, Howard Becker, Pierre Bourdieu, Pierre Levy e Bruno Latour, para citar alguns, um referencial teórico abrangente que necessitaria de muito fôlego para um resgate adequado. Entretanto, por não ser esta a intenção precípua da pesquisa desenvolvida, optou-se por ater-se a um recorte específico dos estudos da moderna Sociologia da Ciência, a Teoria Ator-Rede. Acredita-se que ela representa um referencial adequado para o objetivo pretendido na pesquisa e se enquadra no escopo em que está inserido o estudo que foi desenvolvido.

Esse escopo que contempla como elementos estruturantes e norteadores como pontuado anteriormente: práticas e redes colaborativas para inovação; e-Science e políticas públicas para o fomento científico e tecnológico. A ANT engloba uma abordagem que representa um conjunto teórico, abrangente e orgânico que não obstante sua rica contribuição, "têm sua unidade no esforço de compreender objetos de estudo cada vez mais destacáveis na sociedade contemporânea, a saber, a ciência e a tecnologia." (PREMEBIDA et al., 2011, p. 23).

\section{Sistema Nacional de Ciência, Tecnologia e Inovação}

À criação do Conselho Nacional de Desenvolvimento Científico e Tecnológico (CNPq), e da Coordenação de Aperfeiçoamento de Pessoal de Nível Superior (Capes) é atribuído o início da institucionalização da Ciência brasileira. O CNPq como responsável pelo fomento à pesquisa e a Capes incumbida do apoio à for-

4 Refere-se à metáfora "gigante", utilizada por Isaac Newton ao atribuir aos inúmeros teóricos predecessores a base para a construção dos pressupostos da Ciência, a qual é resgatada por Ziman (1979). 
mação de recursos humanos e, até se chegar a esse patamar, um longo percurso se trilhou no país. Antes da criação desses órgãos o desenvolvimento científico passou por muitas dificuldades (OTAVIANO, 2011).

Durante o processo de consolidação da C\&T no país, ocorreu certa descontinuidade, a qual perpassou regimes políticos, programas e planos governamentais. Em alguns casos, privilegiavam políticas de governo em detrimento de políticas de estado e, em outros, reconheciam o real valor desse binômio para o desenvolvimento do país e investiam criando instrumentos para sua implementação. O resgate da história e política brasileira voltadas para o desenvolvimento da C\&T é apresentado por Valentim (2002), o qual pontua as ações dos governos brasileiros de Getúlio Vargas a José Sarney. Esse referencial é pertinente como base para o entendimento da atual conjuntura que cerca o assunto.

O processo foi marcado por avanços e recuos e a criação de algumas instituições foi significativa para a o desenvolvimento de um Sistema Nacional de Ciência e Tecnologia, mais acentuado durante as décadas de 1960, 1970 e 1980. Destacam-se, em síntese apresentada a seguir, algumas instituições que marcaram este percurso inicial e foram fundamentais para a criação de uma infraestrutura acadêmica e a implantação de políticas para a C\&T:

- a Sociedade Brasileira para o Progresso da Ciência (SBPC), criada em 1948;

- o Centro Brasileiro de Pesquisas Físicas (CBPF), em 1949;

- o Instituto Tecnológico da Aeronáutica (ITA), em 1950;

- o Centro Tecnológico de Aeronáutica (CTA), em 1950;

- o Conselho Nacional Pesquisa, em 1951, transformado em CNPq, em 1974. O propósito inicial da criação desse conselho foi equiparar o Brasil a outras nações desenvolvidas, sobretudo nas questões relacionadas à pesquisa e energia nuclear;

- a Companhia Nacional de Aperfeiçoamento de Pessoal de Nível Superior, em 1951, posteriormente designada de Capes, com o objetivo de qualificar recursos humanos, em atividades científicas e técnicas;

- a fundação da Financiadora de Estudos e Projetos (Finep), em 1967, com o objetivo de fornecer fomento para o desenvolvimento de tecnologia e apoio de sua utilização pela sociedade; 
- a implantação do Ministério da Ciência e Tecnologia (MCT) $)^{5}$ em 1985 que absorveu em sua estrutura a Finep, o CNPq e suas estruturas de pesquisa; e

- o Fundo Nacional de Desenvolvimento Científico e Tecnológico (FNDCT) atuando desde 1985 (LEMOS; CÁRIO, 2013; OTAVIANO, 2011; REZENDE, 2010; VALENTIM, 2002).

Tornou-se evidente a necessidade do desenvolvimento de infraestrutura que permitisse a construção de bases sólidas para resolver os problemas estruturais da sociedade. Pontuam-se como desafios constantes para esse processo as novas fontes de financiamento à pesquisa e ao desenvolvimento tecnológico; os arranjos institucionais que começam a emergir; e os atores que se organizam em diferentes fóruns, movimentos e etapas do processo de criação, desenvolvimento e implementação de políticas para o setor (CENTRO DE GESTÃO E ESTUDOS ESTRATÉGICOS, 2008).

A interferência do tripé CT\&I é cada vez mais percebida. Os investimentos são pontuais, em uma infraestrutura adequada para que o Brasil conquiste a tão almejada igualdade de desenvolvimento para sua sociedade e para que também possa se igualar aos países ditos desenvolvidos.

Em novembro de 2007 foi anunciado o Plano de Ação em Ciência, Tecnologia e Inovação 2007-2010 (PACTI), um importante instrumento para orientar as ações do Estado voltadas para a implementação de uma infraestrutura robusta para o desenvolvimento almejado na Ciência, Tecnologia e Inovação do país. O plano possui metas ambiciosas que dependem, para o seu cumprimento, de atuação articulada e uma gestão compartilhada entre os atores envolvidos. As prioridades do PACTI, segundo o MEC, são norteadas pelos quatro eixos estratégicos da Política Nacional de CT\&I, a saber:

- expansão e consolidação do Sistema Nacional de Ciência, Tecnologia e Inovação;

- promoção da inovação tecnológica nas empresas;

5 O Ministério de Ciência Tecnologia (MCT) mudou a nomenclatura para Ministério da Ciência, Tecnologia e Inovação (MCTI) em 02 de agosto de 2011. A mudança encontra-se na exposição de motivos da Medida Provisória 541, de 2 de agosto de 2011, publicada no Diário Oficial da União de 03 de agosto de 2011 (BRASIL, 2011). 
- pesquisa, desenvolvimento e inovação em áreas estratégicas; e

- ciência, tecnologia e inovação para o desenvolvimento social (BRASIL, 2010, p. 9).

Apresenta-se a seguir, o modelo atual do Sistema Nacional de Ciência, Tecnologia e Inovação (SNCT\&I), com a intenção de identificar os agentes responsáveis pela alocação de recursos, financiamento de projetos e capacitação dos recursos humanos inseridos na pirâmide em que ele é apresentado. Consequentemente, identificam-se também, os agentes responsáveis pela manutenção da infraestrutura de $e$-Science no Brasil e sua interferência na CT\&I nacional.

Figura 4 - Órgãos executores do Sistema Nacional de Ciência Tecnologia e Inovação

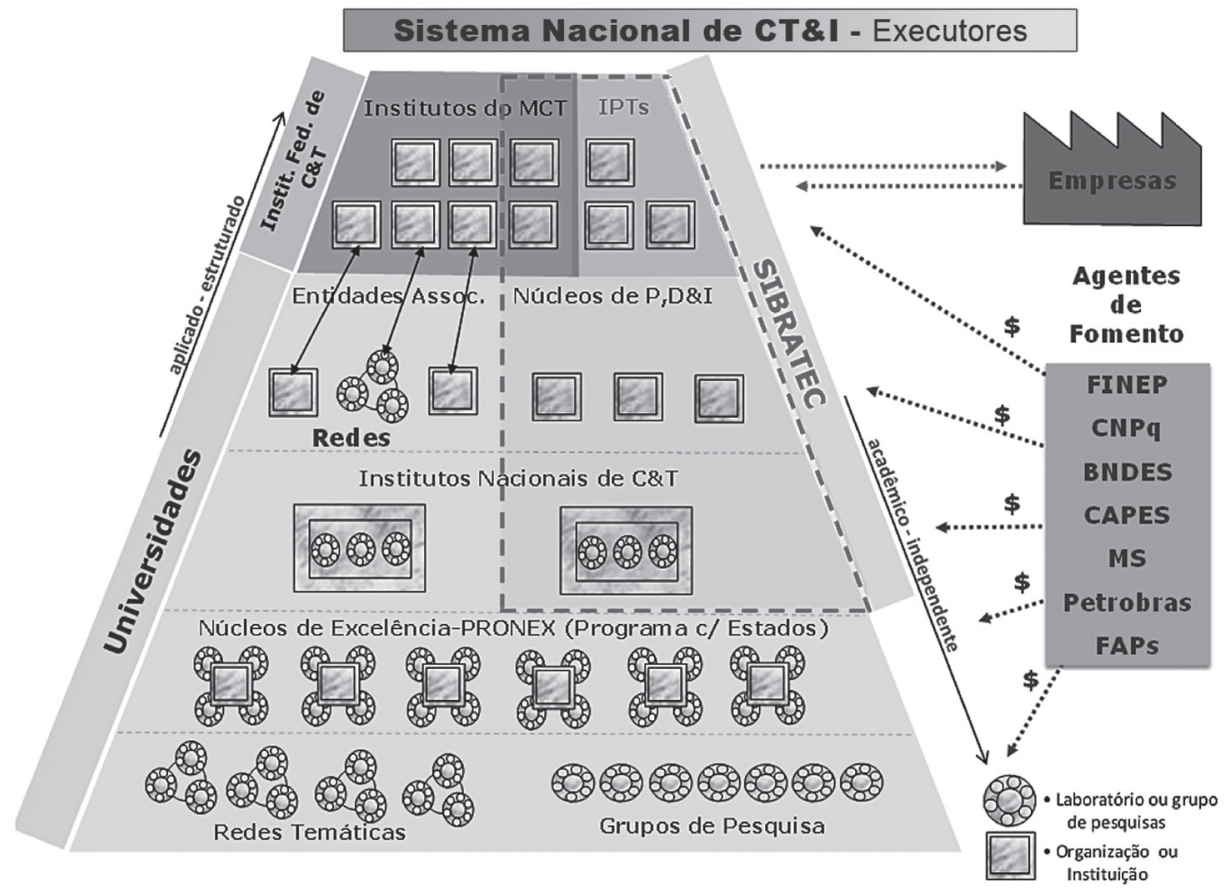

Fonte: Adaptado de SBPC (2011, p. 63).

O modelo do SNCT\&I apresentado na Figura 4, representa a infraestrutura atual de pesquisa no país e foi elaborado pelo Ministério de Ciência e 
Tecnologia (MCT). Sua composição engloba 12 ministérios, 20 unidades de pesquisa, 28 universidades e 25 fundações de amparo à pesquisa estadual (OTAVIANO, 2011). Acrescentam-se ainda a esta composição as diversas empresas públicas e privadas, os agentes de fomentos como a Finep, o CNPq, o Banco Nacional de Desenvolvimento Econômico e Social (BNDES), a Capes, grupos de pesquisa e laboratórios inseridos no âmbito das universidades e institutos de pesquisa.

Uma infraestrutura para pesquisa que se consolida cada vez mais em busca da manutenção de uma constância em suas frentes de atuação além das áreas estratégicas para o desenvolvimento do país. Para tanto, contudo, são necessários investimentos cada vez mais robustos em educação, recursos humanos qualificados e financiamento de projetos nas diversas áreas do conhecimento.

A implantação das diversas modalidades de financiamentos concedidas pelo BNDES, Finep, FNDCT entre outros, foi fundamental para o apoio à infraestrutura de C\&T e aos projetos de pesquisa. Os resultados não tardaram a chegar e mostraram os lucros econômicos gerados com os investimentos realizados, apesar do país ainda não ter alcançado o índice desejado mesmo após três décadas de implantação. Conforme acentua Octaviano (2011), o SNCT\&I "ainda apresenta déficits e alguns pontos fracos, pois pode ser considerado recente, se for comparado ao de outros países desenvolvidos."

As dificuldades vivenciadas pelo MCT foram decisivas para a criação e extinção de instrumentos de financiamento caracterizados como programas ou projetos. Conforme o Centro de Gestão e Estudos Estratégicos (2008, p. 10) os "projetos são definidos como recursos atribuídos a grupos ou indivíduos para a realização de uma atividade de pesquisa limitada na sua abrangência, orçamento e tempo, normalmente pela submissão de uma proposta de pesquisa." Pontua-se a seguir, alguns exemplos de programas implementados e decisivos para a manutenção favorável de uma infraestrutura científica, tecnológica e de inovação para o país.

- o Programa de Apoio do Desenvolvimento Científico e Tecnológico (PADCT), o qual vigorou de 1985 a 1998 e utilizava recursos de empréstimos do Banco Mundial (Bird) e contrapartidas do Tesouro Nacional; 
- o Programa de Apoio a Núcleos de Excelência (Pronex), cujo objetivo era proporcionar apoio financeiro continuado apenas aos grupos de pesquisa de alta competência e eram articulados em redes temáticas;

- o Programa Institutos do Milênio que substituiu o Pronex e visava promover a formação de redes de pesquisa em todo território nacional. Esse programa buscava a excelência científica e tecnológica e o fortalecimento de grupos de pesquisa em qualquer área do conhecimento, assim como as definidas como estratégicas;

- o Programa Jovens Pesquisadores, que apoia projetos de pesquisa e de instalação de infraestrutura;

- o Programa Primeiros Projetos, cujo objetivo é apoiar a aquisição, instalação, modernização ou recuperação da infraestrutura de pesquisa nas instituições públicas de ensino e pesquisa;

- e o Programa Institutos Nacionais de Ciência e Tecnologia (INCTs), criado em 2008 e analisado na pesquisa, a qual derivou esse livro, como veremos com mais detalhadamente no decorrer do estudo, substituiu os Institutos do Milênio (REZENDE, 2010).

A Política de Ciência, Tecnologia e Inovação (PCT\&I) atual possui características do ponto de vista de alocação de recursos que destaca o financiamento a projetos, ao lado do financiamento direto a universidades e a outras instituições de pesquisa. Do ponto de vista de conteúdo, busca atender aos seguintes objetivos: a) fortalecimento e ampliação de uma base de conhecimento ampla e socialmente relevante; b) fortalecimento da interação entre os diversos atores do sistema nacional de inovação; c) descentralização das atividades de produção e uso do conhecimento, desenvolvimento regional e local nas políticas de CT\&I (CENTRO DE GESTÃO E ESTUDOS ESTRATÉGICOS, 2008).

Os maciços investimentos resultaram em um avanço significativo da Ciência nacional, mas conforme destaca Borges (2011, p. 182) em seu diagrama apresentado na Figura 5, é necessária ainda uma atuação de maneira estrutural e estratégica que contemple a tecnologia e a inovação no contexto nacional como uma forma de equilibrar o desenvolvimento do tripé CT\&I. 
Figura 5 - Caracterização da CT\&I no Brasil: (A) vigente (B) desejada
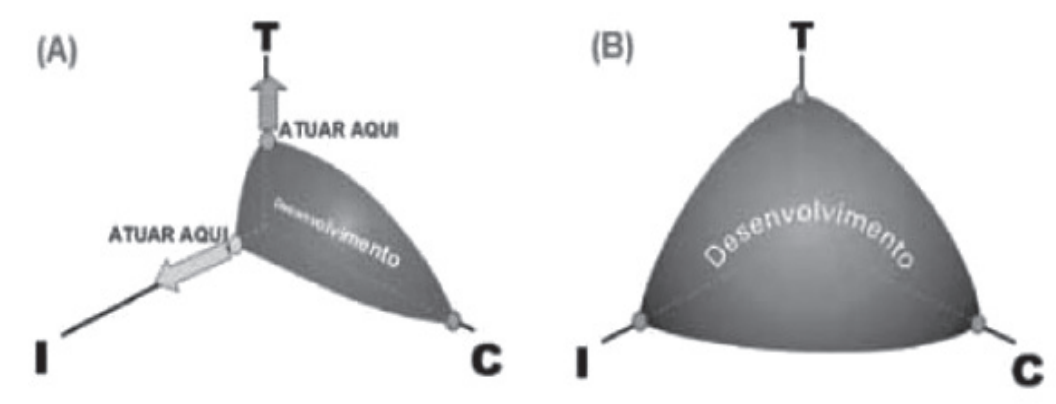

Fonte: Adaptado de Borges (2011, p. 182).

A busca de soluções para mudar a realidade apresentada é constante entre os responsáveis pelo SNCT\&I. Desse modo, é lançado o Programa Institutos Nacionais de C\&T, instituído pela Portaria MCT n ${ }^{\circ}$ 429, de 17 de julho de 2008 (BRASIL, 2008), em substituição ao Programa Institutos do Milênio. O programa que congrega redes cooperativas de pesquisa formadas em torno de um tema comum e tratadas de forma multidisciplinar e os INCTs foram selecionados como locus para o estudo em desenvolvimento. Essa escolha foi pautada, na identificação de semelhanças entre os objetivos e características desses institutos e a infraestrutura de institutos e/ou fundações que acolhem projetos de e-Science desenvolvidos em outros países.

A próxima seção se encarregou de introduzir os detalhes do Programa Institutos Nacionais de Ciência e Tecnologia, a política pública que caracteriza os INCTs e é foco de análise para a e-Science e as práticas colaborativas desenvolvidas por seus pesquisadores.

\section{Programa Institutos Nacionais de Ciência e Tecnologia}

Criado pela Portaria MCT n ${ }^{\circ}$ 429, de 17 de julho de 2008 (BRASIL, 2008), o Programa Institutos Nacionais de Ciência e Tecnologia deveria ocupar uma posição estratégica no SNCT\&I. Ao assinar os convênios para efetivação do Programa que daria início aos INCTs, o então ministro da Ciência e Tecnologia, 
Sergio Rezende, que respondeu pela pasta de julho de 2005 a dezembro de 2010, o considerou um arranjo inovador.

Uma parceria inicial entre o Ministério de Ciência e Tecnologia (MCT), representado pela FNDCT e CNPq; o Ministério de Educação e Cultura (MEC), representado pela Capes; e o Ministério da Saúde (MS), pela Secretaria de Ciência Tecnologia e Insumos Estratégicos (SCTIE) e as Fundações de Amparo à Pesquisa (FAPs): Fundação de Amparo à Pesquisa do Estado de Minas Gerais (FAPEMIG); Fundação Carlos Chagas de Amparo à Pesquisa do Estado do Rio de Janeiro (FAPERJ); e a Fundação de Amparo à Pesquisa do Estado e São Paulo (FAPESP).

Posteriormente somaram-se as parcerias do Ministério do Desenvolvimento, Indústria e Comércio Exterior (MDIC), por meio do BNDES; do Ministério de Minas e Energia (MME), por intermédio da Petrobrás e outras entidades federais e estaduais. Dessa forma personificaram não um programa de uma entidade ou de governo, mas um programa de um país. (BRASIL, 2008; INCT, 2008). O Portal Brasileiro de Ciência e Tecnologia (2013) define os INCTs e destaca sua abrangência, características e objetivos conforme é apresentado a seguir:

Os Institutos Nacionais de Ciência e Tecnologia ou INCTs são centros de pesquisa brasileiros que abrangem todo o território nacional, sendo fomentados por verbas públicas e caracterizados pelo alto padrão de pesquisa científica realizada. $\mathrm{O}$ objetivo desses centros é contribuir para o desenvolvimento da pesquisa e criar patentes para o país, promovendo uma sinergia entre grupos de pesquisadores de diferentes instituições e áreas do conhecimento (PORTAL, 2013).

O Programa Institutos Nacionais de Ciência e Tecnologia foi considerado por autores como Rezende (2010) e Borges (2011) como o maior programa da história do CNPq e um exemplo de sucesso e visava em sua primeira edição:

- mobilizar e agregar, de forma articulada com atuação em redes, os melhores grupos de pesquisa em áreas de fronteira da ciência e em áreas estratégicas para o desenvolvimento sustentável do País, como definidas no PACTI; 
- impulsionar a pesquisa científica básica e fundamental competitiva internacionalmente;

- desenvolver pesquisa científica e tecnológica de ponta associada a aplicações, promovendo a inovação e o espírito empreendedor, em estreita articulação com empresas inovadoras, nas áreas do Sistema Brasileiro de Tecnologia (Sibratec);

- promover o avanço da competência nacional em sua área de atuação, criando para tanto ambientes atraentes e estimulantes para alunos talentosos de diversos níveis do ensino médio ao pós-graduado, e responsabilizando-se diretamente pela formação de jovens pesquisadores. Os Institutos Nacionais devem ainda estabelecer programas que contribuam para a melhoria do ensino de ciências e com a difusão da ciência para o cidadão comum;

- apoiar a instalação e o funcionamento de laboratórios em instituições de ensino e pesquisa e empresas, em temas de fronteira da ciência e da tecnologia, promovendo a competitividade internacional do País, a melhor distribuição nacional da pesquisa científico-tecnológica, e a qualificação do País em áreas prioritárias para o seu desenvolvimento regional e nacional (PROGRAMA..., 2008, p. 3).

A iniciativa possui um conjunto de agentes imbuídos do propósito de reunir grupos de pesquisadores vinculados às universidades e instituições científicas de forma multicêntrica, cujo funcionamento ficou sob a coordenação de uma instituição sede, o MCT/CNPq. Quando foi lançado em 2008, o Programa selecionou 122 INCTs, os quais congregavam os melhores grupos de pesquisa em áreas de fronteira da ciência e em áreas estratégicas para o desenvolvimento do país (CNPq, 2008).

De acordo com os dados levantados nos sítios dos INCTs e notícias veiculadas pelas agências de fomento como a FAPESP, foram selecionados 125 - 122 aprovados pelo Edital 15/2008 e três aprovados pelo Edital 71/2010 (CNPq, 2008; 2010). No Quadro 1, apresenta-se o total dos INCTs e sua inserção nas oito áreas consideradas estratégicas pelo PACTI 2007-2010, para a Ciência, Tecnologia e Inovação, além do total de pesquisadores levantados.

Esse quadro é fruto do primeiro levantamento realizado a partir de dezembro de 2013 até dezembro de 2014, período que compreendeu a coleta inicial dos dados empíricos da pesquisa, a qual derivou esse livro. Esse levantamento 
foi realizado nos sítios individuais dos institutos (INSTITUTO NACIONAL DE CIÊNCIA E TECNOLOGIA, 2014a; 2014b; 2014c; 2014d; 2014e; 2014f); no sítio oficial do CNPq (2013a; 2013b; 2013c) e Portal Brasileiro de Ciência e Tecnologia (PORTAL, 2013). Foram identificados 125 INCTs e 7395 pesquisadores e as atividades realizadas nesses INCTs estão inseridas nas oito áreas estratégicas para a CT\&I, a seguir representadas.

Quadro 1 - INCTs e áreas estratégicas para a CT\&I

\begin{tabular}{|c|l|c|c|}
\hline N. & ÁREAS ESTRATÉGICAS PARA A CT\&I & INCTs & N $^{\circ}$ DE PESQUISADORES \\
\hline 1 & Ciências Agrárias e Agronegócio & 12 & 598 \\
\hline 2 & Energia & 10 & 455 \\
\hline 3 & Engenharia e Tecnologia da Informação & 12 & 734 \\
\hline 4 & Exatas e Naturais & 11 & 555 \\
\hline 5 & Ciências Humanas e Sociais Aplicadas & 10 & 884 \\
\hline 6 & Ecologia e Meio Ambiente & 21 & 1066 \\
\hline 7 & Nanotecnologia & 10 & 855 \\
\hline 8 & Saúde & 39 & 2248 \\
\hline TOTAL & & 125 & 7395 \\
\hline
\end{tabular}

Fonte: Elaborado pela autora.

As características essenciais do Programa dos Institutos Nacionais de Ciência e Tecnologia são:

- a mobilização e agregação dos melhores grupos de pesquisa, de forma articulada em redes;

- o desenvolvimento de programa de pesquisa científica e/ou tecnológica bem definido e estruturado que permita avanços científicos substanciais ou desenvolvimento tecnológico inovador;

- a atuação em áreas estratégicas ou em áreas da fronteira da ciência;

- forte interação com o sistema produtivo e com a sociedade;

- a promoção de pesquisa competitiva e relevante para o país; e 
- a criação de ambiente atraente e estimulante para alunos talentosos de diversos níveis, do ensino médio a pós-graduação, responsabilizando-se pela formação de jovens pesquisadores (REGULAMENTO..., 2008).

O esforço colaborativo estava presente nas instituições e empresas associadas que compuseram o projeto e tornou-se visível a partir da materialização das ações por meio dos recursos financeiros empreendidos. Os recursos iniciais previstos totalizaram R $\$ 275$ milhões, em três anos com a participação estimada de 45 INCTs, recursos esses oriundos do CNPq e FNDCT representando 62,07\% do capital empreendido para alavancar o projeto.

Em virtude da participação acordada com as FAPs dos estados da região sudeste, cerca de R $\$ 135$ milhões foram aportados adicionalmente para aplicações nos respectivos estados, o que permitiu o apoio a cerca de 20 propostas adicionais. A Capes participou com recursos estimados em $\mathrm{R} \$ 30$ milhões representados por bolsas de diferentes modalidades. O financiamento de outras fontes não foi definido no Edital n ${ }^{\circ}$ 15/2008. A Tabela 1, representa o montante inicial investido para a implementação do Programa Instituto Nacionais de Ciência e Tecnologia.

Tabela 1 - Recursos financeiros - Implementação do Programa INCTs

\begin{tabular}{c|c|c|c|c|c}
\hline \multicolumn{7}{c}{ RECURSOS FINANCEIROS (R\$ milhões) } \\
\hline FONTE & 2008 & 2009 & 2010 & TOTAL & $\%$ \\
\hline CNPq & 30.000 .000 & 40.000 .000 & 40.000 .000 & 110.000 .000 & 25,29 \\
\hline FNDCT & 40.000 .000 & 60.000 .000 & 60.000 .000 & 160.000 .000 & 36,78 \\
\hline CAPES & 30.000 .000 & - & - & 30.000 .000 & 6,90 \\
\hline FAPEMIG & 30.000 .000 & - & - & 30.000 .000 & 6,90 \\
\hline FAPERJ & 30.000 .000 & - & - & 30.000 .000 & 6,90 \\
\hline FAPESP & 75.000 .000 & - & - & 75.000 .000 & 17,24 \\
\hline TOTAL & 235.000 .000 & 100.000 .000 & 100.000 .000 & 275.000 .000 & 100 \\
\hline
\end{tabular}

Fonte: Adaptado do CNPq (2008).

A possibilidade de aumento do número dos INCTs era viável em virtude do aporte de recursos de outras entidades federais ou estaduais como, os "Ministé- 
rios da Saúde e da Educação, BNDES e Petrobrás, além de empresas privadas.” (PROGRAMA..., 2008, p. 3). As condições impostas para o funcionamento dos INCTs foram:

- apoio de médio prazo com recursos substanciais, que poderiam ser convertidos em apoio de longo prazo na dependência do desempenho do instituto e do interesse das fronteiras de financiamento listadas [no programa] ou outras;

- atenção ao equilíbrio entre as regiões do país;

- atuação em áreas estratégicas (induzidas) e em áreas da fronteira da ciência induzidas e demanda espontânea;

- promover pesquisa competitiva e relevante para o país;

- formar recursos humanos especializados;

- forte interação com o sistema produtivo e com a sociedade;contribuir para a consolidação de grupos de pesquisa em novos campi universitários e/ou regiões menos favorecidas (PROGRAMA..., 2008, p. 4).

O processo de seleção para o Programa INCTs contemplou a formação de uma comissão de avaliação de elevada competência responsável pela elaboração do edital estruturado e da carta convite, instrumentos elaborados para esta atividade. A comissão de avaliação e acompanhamento do Programa foi nomeada pelo Ministro de Estado da Ciência e Tecnologia e a operacionalização do Programa foi realizada pelas instituições anteriormente citadas: "CNPq, Capes, Ministério da Saúde, BNDES, e Petrobrás, na esfera federal, FAPEMIG, FAPERJ e FAPESP, nos estados do sudeste e outras entidades financiadoras, dentro de suas modalidades de operação.” (PROGRAMA..., 2008, p. 4).

Os INCTs contemplados deveriam atender a um programa de pesquisa científica ou tecnológica, com um tema de atuação claramente definido o qual deveria ser bem estruturado e permitir "avanços científicos substanciais ou desenvolvimento tecnológico inovador". Não deveria ser apenas um projeto de pesquisa ou um conjunto de projetos de pesquisas, mesmo que eles fossem aparentemente vinculados (PROGRAMA..., 2008, p. 4).

O cumprimento de metas quantitativas e qualitativas foi a intenção do Programa INCT. São três as missões básicas por eles englobadas na primeira edição: 
pesquisa, formação de recursos humanos e transferência de conhecimento para a sociedade. Aos institutos voltados a aplicações na Ciência, Tecnologia e Inovação deve ser adicionada a quarta missão, de transferência de conhecimentos para o setor empresarial ou para o governo. Os elementos compreendidos por estas missões são a seguir detalhados e permitem vislumbrar a ousadia e abrangência do projeto implementado:

Pesquisa. Promoção de pesquisa de vanguarda e elevada qualidade, de padrão competitivo internacionalmente na área de conhecimento. $\mathrm{O}$ centro deve ser estruturado e funcionar como uma referência de excelência nacional na sua área de atuação, de modo a contribuir efetivamente para o desenvolvimento nacional segundo as metas definidas no Plano Nacional de Ciência, Tecnologia e Inovação para o Desenvolvimento Nacional.

Formação de Recursos Humanos. O Instituto deve promover a formação de pessoal qualificado, por meio de cursos de pós-graduação, treinamento pós-doutorado e por meio de envolvimento de estudantes de graduação. Para aqueles institutos voltados a aplicações, tecnologia e relações com empresas, espera-se, além da formação de cientistas acadêmicos de nível internacional, que haja treinamento em ambiente empresarial, cursos de curta e longa duração, treinamento de técnicos especializados, entre outros. Para os institutos voltados à ciência básica e fundamental espera-se a formação de cientistas com inserção internacional e com impacto na criação de ciência e em sua difusão.

Transferência de conhecimento para a sociedade, utilizando outros instrumentos além da publicação científica. O centro deve ter um programa ambicioso de educação em ciência e difusão de conhecimento, conduzido por seus pesquisadores e pelos bolsistas a ele vinculado, focalizado no fortalecimento do ensino médio e na educação científica da população em geral.

Transferência de conhecimento para o setor empresarial ou para o governo. Para aqueles voltados a aplicações da ciência, tecnologia e inovação deve haver mecanismos para a interação e sinergia com o setor empresarial, treinamento de pesquisadores e técnicos que possam atuar nas em- 
presas, e iniciativas que facilitem o desenvolvimento conjunto de conhecimento, produtos e processos. Deve apresentar ênfase em todo o ciclo do conhecimento: do desenvolvimento de ideias a produtos comerciais. Sempre que pertinente à sua temática, deve apresentar em sua proposta organizacional ações para além da academia com ênfase em P\&D e transferência de tecnologia e procurar interagir com o Sistema Brasileiro de Tecnologia (Sibratec). Alternativamente, o Instituto poderá apresentar uma proposta que contribua para a formulação de políticas públicas de interesse do estado ou do governo (PROGRAMA..., 2008, p. 5, grifos do autor).

A estrutura dos INCTs compreendeu em seu coletivo, atores e actantes de diversas esferas, as quais foram identificados como os elementos que permitiam o funcionamento dos institutos, e o suporte para o acompanhamento e instrumentalização das atividades. São nomeados como: instituição sede de excelência; conjunto de laboratórios ou grupos externos à sede, associados de outras instituições articuladas na forma de redes científico-tecnológicas; coordenador com um perfil de pesquisador de reconhecida competência nacional e internacional; comitê gestor composto por cinco pesquisadores do projeto e presidido pelo coordenador; e assessores, os advisory board, cientistas de reconhecida competência em sua área de atuação, de preferência do exterior. Esta estrutura é detalhada a seguir, com atribuições pertinentes.

Coordenador: pesquisador de reconhecida competência nacional e internacional na sua área de atuação, pesquisador $1 \mathrm{~A}$ ou $1 \mathrm{~B}$ do $\mathrm{CNPq}$ (ou equivalente) com capacidade para liderar projetos complexos e com vários participantes, e liderança demonstrada por publicações de impacto em revistas científicas, patentes nacionais ou internacionais, e expressivo resultado em orientação de dissertações ou teses e supervisão de pós-doutores;

Gestão: a proposta deverá contemplar a constituição de um comitê gestor, composto por 5 pesquisadores do projeto e presidido pelo coordenador, que deverá aprovar o plano anual de aplicações de recursos do instituto, além de propor as metas anuais de atividades (pesquisa, formação de recursos humanos, transferência de conhecimento) e ava- 
liar a sua execução, aprovando a revisão anual do contrato de gestão [...]. A gestão do instituto, assim como sua coordenação, não se vincula ou se superpõe à administração da entidade que the serve de sede.

Assessores (Advisory board): cada instituto deve sugerir nomes de assessores, cientistas de reconhecida competência na sua área de atuação, de preferência do exterior para funcionarem como consultores, o Comitê de coordenação do Programa [...] escolherá dois nomes, sendo um radicado no exterior. Esses dois consultores devem visitar o instituto anualmente, examinar seu desempenho frente às metas aprovadas pelo comitê gestor do instituto, e emitir parecer por escrito, que servirá de orientação para o instituto.

Sede: uma instituição pública de ensino ou pesquisa consolidada ou instituição privada sem fins lucrativos. Sua participação no programa deverá ser garantida por documento da autoridade maior garantindo uso da estrutura física e participação de pesquisadores e técnicos no desenvolvimento do projeto, oferecendo, quando pertinente, recursos de contrapartida suficientes para o desenvolvimento do projeto;

Laboratórios associados: laboratórios ou grupos de pesquisa externos à sede que se associam para desenvolvimento do projeto, podendo pertencer a instituições públicas, privadas ou empresas. Como no caso da sede, a participação tem que ser autorizada pelo dirigente competente, colocando à disposição do projeto os recursos materiais e humanos necessários. Cada laboratório associado deverá ter um pesquisador responsável (PROGRAMA.., 2008, p. 6, grifo do autor).

A previsão inicial de duração do programa dos INCTs foi de cinco anos; os primeiros três anos teriam o financiamento assegurado e após a avaliação seria concedida a continuidade do apoio aos dois anos restantes. A divisão dos INCTs em três grupos privilegiou as faixas de valores do financiamento e dependiam da necessidade de recursos para execução das propostas. Estas faixas foram classificadas da seguinte forma: 
Faixa A, Institutos envolvidos com atividades que não necessitam de equipamentos ou reagentes de altos custos;

Faixa B, Institutos cujos programas são de natureza experimental, que exigem equipamentos e reagentes de custos baixo e médio; ou

Faixa $C$, Institutos cujos programas são de natureza experimental, que exigem equipamentos e reagentes de alto custo (CNPq, 2008, grifo nosso).

A distribuição dos recursos para as regiões cobertas foi assegurada considerando-se a sede do instituto. As regiões norte, nordeste e centro-oeste obtiveram cerca de 35\% dos recursos, a região sul 15\% e a sudeste 50\% dos recursos (CNPq, 2008).

O Programa INCTs realizou sua primeira avaliação prevista no Edital 15/2008, nos dias 23 e 24 de novembro de 2010, em Brasília, o primeiro balanço das ações desenvolvidas nos últimos dois anos desde o seu lançamento em 2008. O órgão responsável pela coordenação da avaliação foi o Centro de Gestão e Estudos Estratégicos (CGEE), contratado especialmente pelo MCT para participar, junto com o CNPq do trabalho de acompanhamento do programa. O evento foi chamado de I Reunião de Acompanhamento e Avaliação dos INCTs e, a título de incentivo, os institutos que apresentara melhor desempenho conquistaram a prorrogação dos recursos de pesquisa, prevista no Edital 15/2008, por mais 24 meses, além do período regular de três anos (CENTRO DE GESTÃO E ESTUDOS ESTRATÉGICOS, 2010; TORRES, 2010).

A avaliação foi positiva, apesar das dificuldades relatadas pelos coordenadores em questões de gestão e aspectos legais da aplicação dos recursos. Segundo José Carlos Maldonado, coordenador de um dos INCTs avaliados, o Instituto de Ciências Matemáticas e de Computação (ICMC), da USP, "essas dificuldades fazem parte do processo de aprendizagem inerente à implantação dos institutos. Isso é natural porque se trata de um programa inovador, que mudou paradigmas de relações estruturantes e de articulação das instituições científicas no Brasil." (CASTRO, 2010). 
O II Seminário de Acompanhamento e Avaliação dos INCTs foi realizado em Brasília, no período de 02 a 04 de julho de 2013. Nesse evento, foi anunciado pelo então ministro da Ciência, Tecnologia e Inovação, Marco Antonio Rauppo, a continuidade do financiamento ao Programa Institutos Nacionais de Ciência e Tecnologia, renovação dos contratos e mudança do sítio oficial. A previsão de lançamento do novo edital foi anunciada para o período de outubro a novembro de 2013, com avaliações previstas entre fevereiro e setembro de 2014 (CNPq, 2013a).

Entretanto, apesar do lançamento do edital e recebimento das propostas no período de 7 de julho a 8 de setembro de 2014, o resultado da Chamada INCT MCTI/CNPQ/CAPES/FAPS N ${ }^{\circ}$ 16/2014 (CNPq, 2014a) previsto para sair a partir de 6 de março de 2015, somente foi divulgado em 11 de maio de 2016. Do total de 345 propostas submetidas, 115 eram de INCTs já existentes e 230 para criação de novos institutos. O resultado contemplou 252 propostas, as quais receberam recomendação no processo de análise de mérito técnico-científico para financiamento. Os recursos de contestação do resultado da chamada somente poderão ser realizados a partir de 11 de julho de 2016, dois meses após a divulgação do resultado (CNPq, 2016a). 


\title{
A PRÁTICA COLABORATIVA: TRADIÇÃO E CONTEPORANEIDADE
}

\begin{abstract}
Não há dúvida de que a colaboração entre indivíduos, especialmente quando abrangendo disciplinas múltiplas, produz resultados positivos. Certamente a maneira mais eficaz de resolver alguns dos maiores problemas da humanidade (por exemplo, diabetes, AIDS, pobreza, água potável etc.), exigiria largar tudo [a cargo] da melhor e mais brilhante equipe do mundo.
\end{abstract}

(Avi Gladish)

O cenário em que as práticas colaborativas são desenvolvidas foi um dos pontos que chamarão a atenção durante a investigação. Introduziram-se na sequência, as redes colaborativas na busca de identificação dos fios que a tecem. Um esforço despendido com vistas à realização de uma contextualização do corpus da pesquisa, de modo apropriado e utilizando-se os instrumentos e ferramental necessários que potencializem os conhecimentos sedimentados.

\section{Colaboração: práticas, tradição e contemporaneidade}

O termo colaboração é um conceito genérico que deve ser contextualizado para definir a relação desejada entre os participantes. Sua aplicação na Ciência torna-se ainda mais complexa e o pleno entendimento do seu significado está longe de ser alcançado. (BRNA, 1998; VANZ; STUMP, 2010). A etimologia 
descende do termo francês collaboration (1844) e do latim collabõrãre (1858), de co-laborar-ção, ação de labor (trabalho com), ou seja, um trabalho conjunto (CUNHA, 2011).

O conceito de colaboração está ligado às técnicas as quais possibilitam que pessoas dispersas geograficamente possam trabalhar de maneira integrada, como se estivessem fisicamente juntas (VULHERME, 2013). Refere-se a uma atividade em que os indivíduos trocam informações, organizam-se e trabalham em conjunto.

A prática colaborativa se manifesta em ambientes, modelos e níveis diferentes e, a depender do contexto, assume as características que a melhor a representa. Para fins didáticos, Mendes (2009) as divide em quatro níveis:

- colaboração interna, mais voltada para o processo relacionado aos funcionários e colaboradores das corporações e empresas;

- colaboração na cadeia produtiva entre organizações;

- colaboração com consumidores, que é a cocriação de valor, segundo a qual aceitar que a colaboração do cliente/usuário é muito mais poderosa do que a colaboração interna é um dos grandes desafios das organizações; e

- a colaboração em massa, quando são utilizados os ambientes colaborativos digitais e são oferecidas aos usuários plataformas para criar, editar e compartilhar conteúdos próprios.

Acrescenta-se ainda, trazendo-a para o âmbito científico, a colaboração externa, aquela voltada para o processo relacionado aos pesquisadores e colaboradores das instituições de pesquisa e empresas fora do ambiente interno. Ao identificar os modelos de colaboração, Vieira (2009, p. 66) os classifica como: parceria colaborativa; parceria em equipe; e parceria pessoal. A autora destaca ainda que "tais parcerias estão no contexto institucional e podem ser identificadas e distintivas entre nível, fundamentos, estrutura, propriedade e benefícios.”

Referindo-se ao modelo de colaboração do tipo parceria colaborativa, Vieira (2009) distingue como sua principal característica a busca por recursos externos, os quais podem ser tanto de ordem financeira, quanto, principalmente, de recursos humanos. Essa busca que se faz evidente nas instituições tradicionais 
de pesquisa e organizações distribuídas no mercado. Os recursos em questão são fornecidos e financiados pelas políticas implementadas pelas agências de fomento a nível global e os Institutos Nacionais de Ciência e Tecnologia são exemplos desse modelo de colaboração.

Ao se retomar o tema pertinente às classificações do conceito colaboração salienta-se sua divisão por tipo: colaboração em equipe; colaboração em comunidade; e colaboração em rede. Essa última foi estudada, na pesquisa desenvolvida, considerando-se os desmembramentos das redes de práticas colaborativas identificadas nos INCTs analisados.

A colaboração caracteriza-se como um processo recursivo em que duas ou mais pessoas ou organizações trabalham juntas para realizar objetivos comuns, pelo compartilhamento de conhecimento, aprendizagem e construção de consenso. Os avanços tecnológicos potencializaram esta atividade de tal forma que permitiram um raio de alcance extraordinário entre os profissionais que a realizam.

A internacionalização da Ciência, advinda dos esforços colaborativos digitais facilitou a possibilidade de realização de projetos entre pesquisadores dos mais longínquos locais do mundo. A prática colaborativa traduz-se em uma profunda e coletiva determinação para alcançar objetivos idênticos, um tipo de relacionamento com o qual cada indivíduo participa da maioria das decisões, como: escolher a meta, definir as estratégias, definir as tarefas e avaliar o resultado. O pesquisador o faz consciente de que é algo realmente importante para ele, algo que beneficia tanto o grupo como um todo, quanto a ele diretamente (FERREIRA et al., 2009).

O caráter colaborativo está presente no meio científico desde que a Ciência é Ciência, a assertiva de Meadows (1999, p. 107) de que, apesar da existência de pesquisadores solitários, nos primórdios da Ciência "houve colaboração desde o princípio", é pertinente para reforçar essa colocação.

A literatura científica apresenta diversos trabalhos que corroboram a afirmativa de Meadows (1999). Entre eles destacam-se os dos autores González Alcaide e colaboradores (2013, p. 13), os quais resgatam Finholt e Olson quando afirmam que "a colaboração científica não é um fenômeno recente, os cientistas têm trabalhado cooperativamente desde que existe a ciência”. 
A importância do trabalho colaborativo na Ciência também é reconhecida por Solla Price (1976), que o distinguia como um diferencial na transição entre a Grande Ciência e a Pequena Ciência - Big Science e Little Science. Esse autor questionava até que ponto era real a imagem do pequeno cientista como gênio solitário e cabeludo. A introdução do termo colégios invisíveis ${ }^{1}$ é atribuída a Solla Price em uma acepção ao trabalho colaborativo informal desenvolvido pelos cientistas no século XVII.

O surgimento dos grupos científicos impulsionou o trabalho colaborativo como uma atividade orientada, conforme destaca Meadows (1999, p. 108), mas após a segunda guerra mundial ocorreu seu efetivo desenvolvimento.

Essa ideia de trabalho em equipe como uma atividade orientada desenvolveu-se na primeira metade do século $\mathrm{XX}$, quando começaram a surgir grupos científicos formados por assistentes de pesquisa, estudantes de doutorado e técnicos, orientados por pesquisadores seniores. Seu desenvolvimento efetivo, contudo, deu-se após a Segunda Guerra Mundial, em certos campos como a física nuclear e a ciência espacial.

As demandas do mundo contemporâneo exigem cada vez mais a interação entre as pessoas de modo colaborativo. Esse perfil é considerado como principal característica da Ciência contemporânea, não somente em apenas alguns campos restritos, mas em todas as áreas do conhecimento. A ele é creditado também a grande importância nas políticas de C,T\&I. Em estudo realizado Sidone, Haddad e Mena-Chalco (2013, p. 3) destacam:

A ciência moderna possui como característica principal o aumento do perfil colaborativo em todas suas áreas, visto que cerca de $70 \%$ dos artigos produzidos atualmente no mundo estão associados a autores de diferentes instituições e, entre esses, cerca de $44 \%$ é oriundo de esforços colaborativos entre pesquisadores de diferentes países e

1 Conforme Mathias (1979, p. xv), " a ele [Derek de Solla Price] se deve a introdução do termo colégios invisíveis, empregado no século XVII na Inglaterra, numa concepção nova e atual, para designar as faixas formadas por cientistas que trabalham nas fronteiras da Ciência e que se reúnem informalmente para trocar ideias, ocasiões em que fervilham as descobertas ainda não publicadas." 
56\% de colaborações entre pesquisadores em território nacional.

A qualidade na pesquisa e visibilidade na comunidade científica são alguns dos ganhos advindos do trabalho em colaboração, sem contar que, conforme a afirmação de Meadows (1999, p. 109), "a literatura gerada por pesquisas feitas em colaboração mostra diferenças importantes se comparada com a produzida por pesquisadores que trabalham isoladamente." O autor citado ainda ressalta que "as razões básicas do trabalho em equipe encontram-se no crescimento e especialização da pesquisa", a qual demanda uma "gama de conhecimentos e o acesso a recursos consideráveis (em termos de pessoal e finanças) que se situam além das possibilidades de uma única pessoa."

Por despertar interesse como problema de pesquisa, a temática sobre colaboração influenciou a criação de grupos de estudo. Segundo Vans e Stumpf (2010, p. 43), "a colaboração em ciência e tecnologia é um problema de estudo que desperta interesse mundial [...] em $1^{\circ}$ de janeiro de 2000, em Berlim, foi instituída a rede mundial de pesquisa sobre o assunto, denominada 'Collaboration in Science and in Technology' (COLLNET)2."

As formas de medir a Ciência destacam-se entre os assuntos mais correntes na literatura, e é cada vez mais frequente na área da Ciência da Informação. O desenvolvimento da Ciência torna-se mensurável com a produção de indicadores cientométricos, os quais embasam o planejamento e tomada de decisões em diversos âmbitos da sociedade.

As práticas científicas colaborativas realizadas pela comunidade científica possuem métricas que permitem sua mensuração e a construção de indicativos. Facilitam a identificação de padrões, características e comportamentos nas colaborações existentes além de possibilitar a colaboração entre pessoas, grupos de pesquisa, instituições, países, estados etc. A identificação da "coautoria tem sido utilizada com sucesso por muitos pesquisadores das áreas de Bibliometria e Cientometria", conforme destaca Vanz (2009, p. 41), apesar de possuir algumas limitações. A facilidade e praticidade para o exame de uma grande amostra é pontuado pela autora citada como uma vantagem desse método.

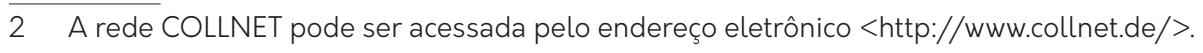


Indicadores voltados para a mensuração das práticas colaborativas realizadas no âmbito dos institutos de ciência e tecnologia apoiam a identificação das interações possíveis nesse contexto. Dentre elas citam-se: as atividades ligadas à $\mathrm{P} \& \mathrm{D}$ como o desenvolvimento de programas e projetos, além da geração de patentes; os diversos serviços prestados em nível de consultoria ou focados em aspectos específicos; os cursos ministrados, entre outras formas (RIZZATO, 2015).

A colaboração científica é um tipo de colaboração tradicional da Ciência que potencializada pelos aliados tecnológicos ganhou um escopo de aplicação global. O termo possui inúmeras definições na literatura acadêmica, contudo, destaca-se a que Lara e Lima (2009, p. 618) apresentam em seu Glossário de termos e conceitos sobre redes sociais e colaborativas, por englobar diversos aspectos apresentados nesta interação como se constata a seguir.

Processo social intrínseco às formas de interação humana para efetivar a comunicação e o compartilhamento de competências e recursos. A colaboração científica é um meio para otimizar recursos, dividir o trabalho, aliviar o isolamento próprio da atividade acadêmica, criar sinergia entre os membros da equipe na conclusão de projetos etc. O processo de colaboração científica é permeado por fatores como: alteração nos padrões e níveis de financiamentos; os anseios por parte dos pesquisadores em aumentar a popularidade, visibilidade e reconhecimento científico; a demanda gradual pela racionalização do poder científico; a necessidade de mais instrumentos, em maior escala e cada vez mais complexos; o aumento da especialização da ciência; o avanço das disciplinas nas quais o pesquisador necessita cada vez mais de conhecimentos de outros pesquisadores; a profissionalização crescente da ciência; a necessidade de adquirir experiência e treinar novos pesquisadores; o desejo de trabalhar interdisciplinarmente entre as áreas; a necessidade de trabalharem em estreita proximidade física com outros pesquisadores para beneficiar-se das habilidades e conhecimentos implícitos. A negociação e a troca na colaboração científica exigem, também, investimentos de ordem sócio-emocional pra manter relacionamentos colaborativos. A colaboração científica pode ser medida a partir da identificação das interações entre os pesquisadores. 
Estudos sistemáticos sobre colaboração científica vêm sendo realizados ao longo dos anos e seus primórdios remontam ao final da década de 1950. Considerada por Lanzel e Schubert (2004, p. 257) como um "fenômeno social complexo", é uma temática pertinente para a área da Ciência da Informação.

$\mathrm{O}$ registro do primeiro artigo escrito em colaboração entre diferentes pesquisadores data do século XVII, em 1665, conforme pontua Bufrem (2010, p. 130) referindo-se ao relato de Beaver e Rosen. Estes autores citados ainda destacaram que "esses primeiros esforços colaborativos envolveram pesquisadores de diferentes países na tentativa de realizar um empreendimento colaborativo entre metas comuns, esforço coordenado e resultados compartilhados."

O trabalho de Vans e Stumpf (2010, p. 44) apresenta uma revisão teórico-conceitual sobre o termo, no qual se observa a dificuldade encontrada pela área para se obter um consenso em relação à aferição do auxílio prestado entre as partes envolvidas. As autoras destacam que "essa é uma avaliação que pode variar muito de acordo com a área do conhecimento e, até mesmo, conforme a percepção pessoal do cientista”.

Resgata-se, a seguir, alguns dos conceitos destacados por Albagli e colaboradores (2013), como práticas colaborativas contemporâneas, com o intuito de melhor apropriação dos seus significados. Os conceitos em destaque são: as redes de conhecimento; a estratégia empresarial de cocriação; a produção peer-to-peer; a inovação aberta; o crowdsourcing; e a open Science.

As redes de conhecimento segundo Tomaél (2008) é a junção de pessoas e/ ou organizações que compartilham informações e constroem conhecimentos por meio de suas interações. Entretanto, segundo a autora, "os argumentos que demarcam as redes de conhecimento divergem, parece não apresentarem coerência suficiente para caracterizá-las. Apesar de indubitavelmente relacioná-las a informação e ao conhecimento”. A informação que circula nesse ambiente carece de interpretação, ela é normalmente subjetiva e provém de um ator que coopera na rede com sua bagagem intelectual, cultural e organizacional.

Nas redes de conhecimento a informação é seu foco de estudo e é por meio dela que o conhecimento individual apresenta sua contribuição e traz parcerias com benefícios recíprocos. Com o intuito de identificar e analisar os conceitos e abordagens pertinentes a redes de conhecimentos, Tomaél (2008), em seu estudo, 
apresenta as articulações em redes e identifica a concepção de cooperação como o elemento essencial nesse construto; indica ainda, as principais abordagens referentes às redes de conhecimento e resgata as vantagens destacadas por Creech e Willard, sintetizadas e apresentadas como:

- a ênfase na criação de valores comuns por todos os seus membros, que se movimentam por meio do compartilhamento da informação, visando à reunião e a criação de novos conhecimentos;

- o fortalecimento e a capacidade de pesquisa e de comunicação por todos os membros na rede;

- e a identificação e implementação de estratégias que exigem maior empenho dos responsáveis na tomada de decisões, isso por que movimentam o conhecimento dentro de políticas e práticas adotadas pelos participantes.

As redes de conhecimento configuram-se em um fenômeno marcante no mundo contemporâneo conforme ressalta Belluzzo (2013, p. 7), "que interligam pessoas e organizações, sendo consideradas além das meras plataformas tecnológicas na medida em que se constituem em práticas sociais e empresariais".

A estratégia empresarial de cocriação é frequentemente confundida com coworking e algumas vezes considerada equivalente a crowdsourcing. De maneira geral, é concebida e emulada como um processo participativo conduzido por uma instância centralizada, no qual ocorre a participação do cliente na produção. "Atribui-se a Coimbatore Krishnarao Prahalad e a Ventak Ramaswamy a autoria do termo co-creation em um artigo da Harvard Business Review intitulado “Co-Opting Customer Competence” (FRANCO, 2012, p. 13).

A produção peer-to-peer (P2P) segundo Cunha e Cavalcanti (2008, p. 278), é uma "forma de processo cooperativo em que existe comunicação entre as aplicações”. Para Lemos (2005, p. 6) P2P é um sistema de compartilhamento marcante da cibercultura, a qual "possibilita a troca de arquivos de diversos formatos ao redor do mundo, revelando redes de sociabilidade que colocam em evidência a "cibercultura-remix"”.

O crowdsourcing que "é um modelo de criação coletiva e em massa, cuja essência é a cooperação entre os participantes. Trata-se de uma forma de utilizar 
a mídia eletrônica para democratizar o conhecimento, em tradução literal, crowdsourcing significa fonte de informações de uma multidão." (OLIVEIRA, 2012).

A inovação aberta, Open Innovation é um tema resgatado por Mendes (2009) quando trata do poder da colaboração. Conforme Rizzato e colaboradores (2015), para o desenvolvimento de pesquisas voltadas para inovação o conceito de colaboração ou parceria entre empresas e de empresas com universidades e institutos de pesquisa não é novo. Entretanto, Henry Chesbrough criou o termo inovação aberta e atribuiu-lhe premissas e modelos mentais distintos dos até então vigentes. O Quadro 2, resgata os princípios que diferenciam a inovação fechada da inovação aberta.

Quadro 2 - Princípios da inovação fechada e aberta

\begin{tabular}{|l|l|}
\hline \multicolumn{1}{|c|}{ Inovação fechada } & \multicolumn{1}{|c|}{ Inovação aberta } \\
\hline $\begin{array}{l}\text { Os melhores de nossa área trabalham para } \\
\text { nós. }\end{array}$ & $\begin{array}{l}\text { Nem todos os melhores trabalham conosco. } \\
\text { Precisamos contar com os melhores dentro e } \\
\text { fora de nossa companhia. }\end{array}$ \\
\hline $\begin{array}{l}\text { Para lucrar com P\&D, nós mesmos } \\
\text { precisamos desenvolver e fornecer } \\
\text { resultados. }\end{array}$ & $\begin{array}{l}\text { P\&D externa pode criar valor significativo; } \\
\text { P\&D interna é necessária para conquistar } \\
\text { determinada parte desse valor. }\end{array}$ \\
\hline $\begin{array}{l}\text { Quando a descoberta é nossa, sempre a } \\
\text { lançaremos no mercado. }\end{array}$ & $\begin{array}{l}\text { Não somos obrigados a gerar pesquisa para } \\
\text { poder lucrar com ela. }\end{array}$ \\
\hline $\begin{array}{l}\text { A companhia que primeiro lança um a } \\
\text { inovação no mercado sempre fica com esse } \\
\text { mercado. }\end{array}$ & $\begin{array}{l}\text { Construir um modelo de negócio melhor é mais } \\
\text { útil que chegar ao mercado primeiro. }\end{array}$ \\
\hline $\begin{array}{l}\text { Se criarmos as melhores e mais numerosas } \\
\text { ideias na indústria, o sucesso é garantido. }\end{array}$ & $\begin{array}{l}\text { Se fizermos o melhor uso de ideias internas e } \\
\text { externas, o sucesso será nosso. }\end{array}$ \\
\hline $\begin{array}{l}\text { Precisamos ter o controle de nossas } \\
\text { patentes intelectuais, de tal forma que os } \\
\text { concorrentes não se beneficiem com nossas } \\
\text { ideias }\end{array}$ & $\begin{array}{l}\text { Temos de produzir receitas com a utilização, } \\
\text { por terceiros, de nossas patentes e também } \\
\text { que isso aperfeiçoar nosso modelo de negócio. }\end{array}$ \\
\hline
\end{tabular}

Fonte: Adaptado de Chesbrouch (2012).

O pressuposto da inovação aberta é o que "o conhecimento está globalmente distribuído e as empresas não têm recursos suficientes para confiarem somente na pesquisa desenvolvida internamente". O modelo de inovação aberta é altamente colaborativo, ao considerar "que o conhecimento encontra-se em qualquer lugar 
da rede de colaboradores da organização e no mundo globalizado. Isso se dá por meio de parcerias, com e entre seus diversos associados, e o desenvolvimento de redes de conhecimento e aprendizagem." (MENDES, 2009, p. 96). Transpor as fronteiras é a ideia subjacente para acelerar o desenvolvimento interno de inovações.

As práticas colaborativas, especialmente as desenvolvidas entre os institutos, caracterizam-se pelos mais diversos tipos possíveis. Elas podem adquirir o caráter de interações diretamente associadas às necessidades de P\&D da empresa, apoiar demandas de capacitação, prestação de serviços ou mesmo representar oportunidades de imagem por meio de apoios e patrocínios (RIZZATO et al., 2015). A necessidade da realização de projetos e estudos que fortaleçam a inserção no mercado favorece a implementação das parcerias diversas que ocorrem entre as universidades, empresas e institutos de ciência e tecnologia. O Quadro 3 ilustra algumas interações possíveis.

Quadro 3 - Práticas colaborativas - Interações

\begin{tabular}{|c|c|}
\hline \multicolumn{2}{|r|}{ INTERAÇÕES ENTRE UNIVERSIDADES, EMPRESAS E INSTITUTOS } \\
\hline $\begin{array}{c}\text { Atividades } \\
\text { ligadas à } P \& D\end{array}$ & $\begin{array}{l}\text { - Centros programas ou projetos de P\&D - Geração potencial de patente } \\
\text { (cotitularidade) ou Know-how (solução) } \\
\text { - Licenciamento de tecnologia } \\
\text { - Patentes com ou sem desenvolvimento complementar } \\
\text { - Know-how (fornecimento de tecnologia) com desenvolvimento } \\
\text { complementar }\end{array}$ \\
\hline Serviços & $\begin{array}{l}\text { - Prestação de serviços especializados (ensaios, testes, validação) } \\
\text { - Consultoria (caracterização, diagnóstico etc.) }\end{array}$ \\
\hline Capacitação & $\begin{array}{l}\text { - Cursos e treinamentos } \\
\text { - Iniciação científica } \\
\text { - Mestrado } \\
\text { - Doutorado } \\
\text { - Pós-Doc }\end{array}$ \\
\hline $\begin{array}{c}\text { Apoio a } \\
\text { eventos, } \\
\text { programas e } \\
\text { infraestrutura }\end{array}$ & $\begin{array}{l}\text { - Patrocínios a eventos } \\
\text { - Workshops } \\
\text { - Projetos culturais (Lei Rouanet) e do esporte (Lei de Incentivo ao Esporte) } \\
\text { - Doação de recursos para infraestrutura na ICT (construção de laboratórios, } \\
\text { equipamentos etc) }\end{array}$ \\
\hline
\end{tabular}

Fonte: Adaptação de Rizzato e colaboradores ( 2015). 
O open science se destaca deste conjunto de práticas como norteadora em um cenário distinto e inovador, o qual abre precedentes para a discussão de diversas abordagens relacionadas às mudanças na produção e disseminação do conhecimento. Em sua tradução literal significa ciência aberta e faz referência a uma 'filosofia aberta', a qual definiu o movimento observado nos últimos anos em direção ao uso de ferramentas, estratégias e metodologias que denotam um novo modelo de representar um igualmente novo processo de comunicação científica [...]. Compreende, entre outras questões, software aberto (ou livre); arquivos abertos; acesso aberto (COSTA, 2006). A colaboração em ambientes virtuais constitui uma das características da $e$-Science anteriormente destacada.

\section{Fios que tecem uma rede colaborativa}

Atualmente, segundo Musso (2013, p. 17), “a noção de 'rede' é onipresente, e mesmo onipotente, em todas as disciplinas [...] tomando o lugar de noções outrora dominantes, como o sistema ou a estrutura". Entretanto, a ideia de rede existe desde os primórdios da humanidade, presente "na mitologia através do imaginário da tecelagem e do labirinto, e na Antiguidade, [com] a medicina de Hipócrates", associada à metáfora do organismo, ideia que se perpetua-se ao longo do tempo e com acepções as mais diversas. "A formação de redes é uma prática humana muito antiga”, como afirma Castell (2003, p. 7), mas que ganhou vida nova em nosso tempo.

A palavra rede (réseau) somente aparece na língua francesa no século XII, vinda do latim retiolus, diminutivo de retis e do francês antigo résel (MUSSO, 2013). No campo das ciências sociais, conforme Marques (2000) esse termo tem três usos distintos: como metáfora, como concepção normativa e como método de descrição e análise das relações presentes.

O uso do termo rede na área das ciências sociais é apresentado por Marques, e sinaliza sua ocorrência em três momentos, como destacado a seguir:

Em primeiro lugar, como metáfora, uso mais comum e disseminado, em que se quer expressar a noção de que entidades, indivíduos ou mesmo ideias estão de alguma forma conectados entre si. Em segundo lugar, as redes são concebidas normativamente, determinando certas configurações de um dado conjunto de entidades. Finalmente, 
é feita a abordagem das redes quanto à especificidade da análise de redes sociais, não considerando-a apenas como um aspecto estruturador, mas também, como método de descrição e análise das relações nelas presentes (ANDRADE, 2004, p. 2).

A literatura científica está recheada de trabalhos que tratam dessa temática analisando-a em suas diversas nuances. Destacam-se entre eles:

- o trabalho de Dias e Silveira (2005), o qual convida ao diálogo e aprofundamento das questões que envolvem o conceito, e busca contribuir para o debate teórico e metodológico sobre a construção das redes e suas relações com as sociedades e os territórios;

- o de Castells (2006), o qual, ao sentir a emergência da sociedade em rede, diz-nos que elas constituíram a nova morfologia social de nossa sociedade;

- o de Pretto e Silveira (2008. p. 9), no qual acentuam a necessidade da discussão sobre a assertiva de que "na sociedade da informação, na era das redes, o conhecimento cresce mais rapidamente quanto mais for compartilhado [...]";

- o de Duarte, Quandt e Souza (2008), os quais propõem uma visão panorâmica e vertical desse tema e agregam textos selecionados em diversas áreas do conhecimento, nas quais são encontradas teorias e aplicações desse conceito;

- o de Parente (2013), que busca nos fazer compreender que, se quisermos entender o mundo em que vivemos qualquer que seja o domínio considerado, devemos pensar sobre a noção de rede;

- e o de Población, Mugnaini e Ramos (2009), no qual buscam um entendimento da dinâmica das redes sociais mapeadas pelas comunidades científicas.

Levando-se em consideração as diversas idiossincrasias disciplinares representadas nos textos apresentados, todos compartilham um pensamento comum: o de que a rede se tornou uma dimensão indissociável, ontológica e prática de modalização do mundo e da subjetividade.

Ao enquadrar o significado do termo "rede" (network) no contexto contemporâneo, Marteleto (2001, p. 72) o define como "sistema de nodos e elos; estru- 
tura sem fronteiras; uma comunidade não geográfica; um sistema de apoio ou um sistema físico que se pareça com uma árvore ou uma rede”. A representação do "conjunto de participantes autônomos, unindo ideias e recursos em torno de valores e interesses compartilhados" é a derivação do conceito de rede, "a rede social”. Segundo a autora citada, na área das Ciências Sociais, o conceito de redes auxilia na manutenção do conflito entre as diferentes correntes.

Ao resgatar o contexto histórico referente à temática de redes, Marteleto (2001, p. 72) acrescenta ainda que o "trabalho pessoal em redes de conexões é tão antigo quanto a história da humanidade" e a percepção das pessoas para o seu potencial como ferramenta organizacional enfatizou-se nas últimas décadas. A autora citada pontua ainda que ocorreram investimentos acadêmicos nos estudos de redes, a partir do campo das relações internacionais, tendo significação na história recente das ciências políticas. Destaca ainda que "nas redes sociais, há valorização dos elos informais e das relações, em detrimento das estruturas hierárquicas". O estudo das redes evidencia que "os indivíduos dotados de recursos e capacidades propositivas, organizam suas ações nos próprios espaços políticos em função de socializações e mobilizações suscitadas pelo próprio desenvolvimento das redes".

Em sua análise, Brandão e colaboradores (2007) apresentam uma série de estudos de autores estrangeiros que abordam as redes sociais em suas temáticas, em que se destacam os conceitos, a aplicabilidade, o lastro histórico dos estudos e os padrões de colaboração identificados nos círculos sociais diversos. No Brasil, existem pesquisadores que realizam trabalhos com a temática de redes sociais no campo da Ciência da Informação.

Dentre esses estudos estão: os de Matheus e Silva (2006); de Marteleto (2001), na análise dos fluxos de informação; de Tomaél, Alcará e Di Chiara (2005); de Marteleto e Tomaél (2005), nos estudos de redes de colaboração científica e metodologia de Análise de Redes Sociais; de Parreiras e colaboradores (2006) e Silva e colaboradores (2006), sobre interdisciplinaridade. As redes de colaboração configuram-se em fonte inesgotável para estudos, os quais foram sistematizados e apresentados no breve histórico realizado por Balancieri e colaboradores (2005). A cronologia em que ocorreram é apresentada no Quadro 4. 
Quadro 4 - Cronologia de redes de colaboração científica

\begin{tabular}{|c|c|c|c|}
\hline \multicolumn{4}{|c|}{ REDES DE PESQUISA } \\
\hline Década de 60 & Década de 70 & Década de 80 & Década de 90 \\
\hline Início dos estudos & $\begin{array}{l}\text { Áreas do } \\
\text { conhecimento } \\
\text { colaborativas (quais e } \\
\text { porque) }\end{array}$ & $\begin{array}{l}\text { Questionamentos } \\
\text { relativos à definição } \\
\text { de colaboração }\end{array}$ & \begin{tabular}{|l} 
Colaborações \\
internacionais \\
versus colaborações \\
nacionais
\end{tabular} \\
\hline $\begin{array}{l}\text { Investigação das } \\
\text { formas colaborativas }\end{array}$ & $\begin{array}{l}\text { Comparação } \\
\text { entre as áreas do } \\
\text { conhecimento }\end{array}$ & $\begin{array}{l}\text { Diferenças em } \\
\text { qualificar alguém } \\
\text { como colaborador }\end{array}$ & $\begin{array}{l}\text { Fase pré-web: } \\
\text { colaborações } \\
\text { decrescem com a } \\
\text { distância geográfica }\end{array}$ \\
\hline $\begin{array}{l}\text { Identificação dos } \\
\text { "Colégios invisíveis" }\end{array}$ & $\begin{array}{l}\text { Identificação dos } \\
\text { pesquisadores, } \\
\text { instituições e países } \\
\text { envolvidos }\end{array}$ & $\begin{array}{l}\text { Influência de artigos } \\
\text { com maior número } \\
\text { de coautores }\end{array}$ & $\begin{array}{l}\text { Comparação dos } \\
\text { trabalhos teóricos } \\
\text { com trabalhos } \\
\text { experimentais }\end{array}$ \\
\hline $\begin{array}{l}\text { Maioria das } \\
\text { publicações - } \\
\text { coautoria }\end{array}$ & $\begin{array}{l}\text { O número de } \\
\text { coautorias correlatos } \\
\text { com o seu impacto }\end{array}$ & $\begin{array}{l}\text { Contagem de } \\
\text { coautores como } \\
\text { medida mais usada }\end{array}$ & $\begin{array}{l}\text { Visão dos diferentes } \\
\text { níveis de colaboração }\end{array}$ \\
\hline $\begin{array}{l}\text { Coautoria entre } \\
\text { orientador e } \\
\text { orientado }\end{array}$ & $\begin{array}{l}\text { Os "Colégios } \\
\text { invisíveis" possuem } \\
\text { alta produtividade }\end{array}$ & $\begin{array}{l}\text { Fatores } \\
\text { determinantes para a } \\
\text { colaboração científica }\end{array}$ & $\begin{array}{l}\text { Junção de várias } \\
\text { áreas para } \\
\text { entendimento e/ } \\
\text { ou visualização das } \\
\text { redes }\end{array}$ \\
\hline $\begin{array}{l}\text { Teoria do "Mundo } \\
\text { pequeno" }\end{array}$ & $\begin{array}{l}\text { Fortalecimento da } \\
\text { coautoria }\end{array}$ & - & - \\
\hline $\begin{array}{l}\text { Seis graus de } \\
\text { separação }\end{array}$ & - & - & - \\
\hline
\end{tabular}

Fonte: Adaptado de Balancieri e colaboradores (2005, p. 65).

As ferramentas e ambientes colaborativos desenvolvidos com o advento das TICs permitiram estudos e projetos cada vez mais complexos com a temática das redes de colaboração científica. No Brasil identificam-se algumas iniciativas voltadas para a disseminação da produção científica e tecnológica, as quais estão inseridas no âmbito dessas redes e que, apesar de terem sido criadas há algum tempo, também se identificam com os pressupostos intrínsecos à infraestrutura da $e$-Science por fornecerem insumos para o desenvolvimento dos estudos científicos.

Essas redes favorecem o desenvolvimento de pesquisas cientificas à medida que oferecem o suporte para o fornecimento de informações científicas e tecnológicas e dados brutos. Elas se coadunam com o princípio basilar desse modelo e, apesar de não cobrirem a gama de dados que a e-Science incorpora em sua 
totalidade, atuam como parceiras no compartilhamento e disponibilização de seus recursos, como um prenúncio e auxílio do tempo atual do "dilúvio de dados" e avalanche informacional que é presenciado pela sociedade contemporânea. Na sequência, apresentam-se alguns exemplos das redes cooperativas, acima sinalizadas.

O Catálogo Coletivo Nacional de Publicações Seriadas (CCN), ${ }^{3}$ coordenado pelo Instituto Brasileiro de Informação em Ciência e Tecnologia (IBICT), criado desde 1958, mas disponibilizado na WEB a partir de 1998. Caracteriza uma rede cooperativa de unidades de informação localizada no Brasil, a qual tem como objetivo reunir, em um único Catálogo Nacional de acesso público, as informações sobre publicações periódicas técnico-científicas disponíveis em centenas de catálogos distribuídos nas diversas bibliotecas do país. Desse modo, possibilita a difusão do conhecimento, identificação e a localização dos periódicos nacionais e internacionais existentes no país (IBICT, 2005).

O Programa de Comutação Bibliográfica (COMUT), ${ }^{4}$ o qual foi implantado respaldado na necessidade de dotar o país de mecanismos que permitissem um serviço organizado e estruturado de uso compartilhado de informações técnico-científicas. Criado em 1980, por meio do esforço conjunto do Ministério de Educação (MEC), por intermédio da Companhia Nacional de Aperfeiçoamento de Pessoal de Nível Superior (Capes), da Secretaria de Educação Superior (SESu) e do Ministério de Ciência e Tecnologia (MCT), por meio do IBICT e da Financiadora de Estudos e Projetos (Finep).

O serviço foi informatizado no ano de 1997 e passou por diversas modificações nos anos seguintes, com vistas a acompanhar as modernas técnicas de acesso ao documento que estavam aparecendo na época (RODRIGUES, 2005).

O Projeto Scientific Eletronic Library Online (SciELO), ${ }^{5}$ uma biblioteca eletrônica de publicações científicas, financiada pela Fundação de Amparo à Pesquisa do Estado de São Paulo (FAPESP) e implementada em parceria com o Centro Latino Americano e do Caribe de Informação em Ciências da Saúde (Bireme).

\footnotetext{
3 O CCN pode ser acessado pelo endereço eletrônico: <http://ccn.ibict.br/busca.jsf>.

4 O COMUT pode ser acessado pelo endereço eletrônico: <http://comut.ibict.br/comut/do/ index?op=filtroForm>.

5 A biblioteca eletrônica do SciELO pode ser acessada pelo endereço eletrônico: <http://www. scielo.org/php/index.php>.
} 
A implantação desse projeto começou em 1997, operando publicamente a partir de 1998. É um recurso que visa tornar a literatura científica brasileira mais visível e acessível por meio eletrônico e possui critérios e metodologia de avaliação como o fator de impacto e o índice de citação, para a inserção de títulos em seu portal. Pode ser utilizada como um instrumento confiável de disseminação da publicação científica brasileira e permite, entre outras coisas, o estabelecimento de estratégias e políticas de gestão científica (ANTONIO; PACKER, 1998; MENEGHINI, 1998).

A Biblioteca Digital Brasileira de Teses e Dissertações (BDTD), ${ }^{6}$ foi desenvolvida no âmbito do programa da Biblioteca Digital Brasileira, com apoio da Finep e possui um Comitê Técnico-Consultivo (CTC), o qual foi instalado em abril de 2002. Este comitê é constituído por representantes do IBICT, do Conselho Nacional de Desenvolvimento Científico e Tecnológico (CNPq), do MEC (Capes e $\mathrm{SESu}$ ), da Finep e das três universidades que participaram do grupo de trabalho e do projeto-piloto (Universidade de São Paulo (USP); Pontfícia Universidade Católica do Rio de Janeiro (PUC-Rio); e a Universidade Federal de Santa Catarina (UFSC)).

Um projeto coordenado pelo IBICT, o qual integra os sistemas de informação de teses e dissertações existentes nas instituições de ensino e pesquisa brasileiras, estimula também o registro e a publicação de teses e dissertações em meio eletrônico. Esse projeto, uma iniciativa inovadora do IBICT, em parceria com as instituições brasileiras de ensino e pesquisa permite que a comunidade brasileira de C\&T publique suas teses e dissertações produzidas no país e no exterior, dando maior visibilidade a produção científica nacional (BIBLIOTECA DIGITAL BRASILEIRA DE TESES E DISSERTAÇÕES, 2014).

Os Repositórios Institucionais e de Dados que, segundo Crow (2002), foram definidos no contexto universitário como coleções digitais de documentos que armazenam, preservam e disponibilizam o acesso à produção científica de uma ou mais universidades, instituições, centros e/ou departamentos de pesquisa. Essas coleções podem ser produzidas por pesquisadores, docentes, discentes e demais membros da instituição. Eles têm uma importante função institucional, a partir do momento em que passam a gerenciar a documentação produzida,

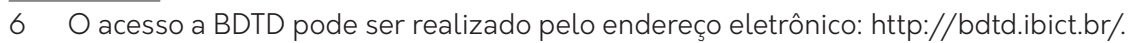


além da preocupação com o seu acesso, disseminação e preservação. São necessários para o sucesso da implementação, apoio e reconhecimento da comunidade acadêmica (FERREIRA, 2009).

O Portal de Periódicos da Capes, '7 que foi oficialmente lançado em 11 de novembro de 2000, pelo governo brasileiro, como fruto de uma iniciativa do MEC, com o objetivo de democratizar o acesso gratuito às informações contidas em periódicos nacionais e estrangeiros e a bases de dados. Desse modo, contribuiu com o desenvolvimento do ensino e da pesquisa em todas as áreas do conhecimento humano.

O lançamento do Portal coincidiu com uma época em que bibliotecas virtuais começavam a ser criadas e as editoras científicas iniciavam o processo de digitalização dos seus acervos. Com o Portal, a Capes passou a centralizar e otimizar a aquisição desse tipo de conteúdo, por meio da negociação direta com editores internacionais, tornando-se assim, uma ferramenta indispensável para estudiosos e pesquisadores engajados na construção do desenvolvimento da produção científica e tecnológica nas universidades brasileiras.

Quando lançado, em 2000, o Portal contava com o acervo de 1419 títulos de periódicos e mais nove bases de dados referenciais em todas as áreas do conhecimento (CAPES, 2011). Atualmente disponibiliza para a comunidade mais de 38 mil publicações periódicas nacionais e internacionais, bases de dados referenciais, de texto completo e patentes, além de livros, enciclopédias e obras de referência, normas técnicas, estatísticas e conteúdo áudio visual.

Os colaboratórios configuram-se como mais uma iniciativa característica da utilização contemporânea dos artefatos tecnológicos em prol de um fazer científico de modo colaborativo e em ambientes virtuais. Dessa maneira, possibilitam agregar pesquisadores dispersos geograficamente para realizarem pesquisas e produzirem conhecimento, utilizando-se dos recursos computacionais disponibilizados em tempo real. Conforme Moura e Morais, (2015) o termo colaboratório foi proposto pelo cientista de computação William Wulf, em 1989, "para destacar as transformações aportadas à produção científica contemporânea

$7 \quad \mathrm{O}$ acesso ao Portal de Periódicos de Capes pode ser realizado pelo endereço eletrônico: http://www.periodicos.capes.gov.br/. 
devido à presença maciça das tecnologias da informação e comunicação em rede. Os autores complementam que os colaboratórios,

integram o movimento da ciberinfraestrutura que é conceitualmente articulado por computação distribuída, informações digitais retrospectivas e prospectivas, interfaces digitais amigáveis (ubíquas, multimodais, nômades e imersivas) além de interfaces para o mundo físico com a estruturação de plataformas de observação autônomas (MOURA; MORAIS, 2015).

Sintonizados com o fazer científico contemporâneo, os colaboratórios, conforme Torres, Pereira e Máximo (2012, p. 6) "surgem como um átrio no qual os cientistas têm oportunidades de trocar, compartilhar, produzir, disseminar, adquirir e utilizar conteúdos (informações e conhecimentos) digitais". Esses autores complementam ainda que "os colaboratórios são espaços virtuais de aprendizagem que, estruturados sob uma lógica sóciointeracionista e com ferramentas da web 2.0, tendem a potencializar a construção de novos conhecimentos e aprendizagens entre os cientistas das redes de pesquisa".

Atenta-se para o potencial atribuído aos colaboratórios e são indicados seus objetivos tomando-se por exemplo o que foi desenvolvido na Universidade Federal de Minas Gerais, como indica-se a seguir:

- identificar os acervos, objetos e dispositivos de pesquisa científica, ensino e extensão universitária desenvolvido na UFMG e o fluxo de produção e circulação de tais documentos;

- identificar os pesquisadores envolvidos em ações de produção e difusão científica e cultural através de acesso aberto;

- gerenciar e tratar a informação disponível em acervos da pesquisa cientifica da UFMG via tecnologia de acesso aberto;

- manter um repositório aberto de recursos informacionais multimodais orientados pelo acesso livre e por uma perspectiva transdisciplinar na composição do acervo.

- sistematizar e propor políticas que garantam em longo prazo a interoperabilidade, a preservação e a acessibilidade dos recursos digitais gerados na pesquisa, ensino e extensão produzidos na UFMG; 
- realizar cursos de formação e sensibilização da comunidade acadêmica para a política de auto-arquivamento de documentos eletrônicos gerados na pesquisa e que sejam de interesse público, que respeite princípios éticos de difusão da informação e que não tornem vulneráveis a condução de novos estudos;

- disseminar tecnologias de acesso aberto voltados à criação, à colaboração e à produção científica e cultural em rede no âmbito da UFMG;

- produzir, adequar e manter ferramentas voltadas à formação de redes de comunicação entre os pesquisadores como forma de fomentar a produção colaborativa em rede (MOURA; MORAIS, 2015).

Contudo, apesar das iniciativas apresentadas, importantes para a construção de uma base para a disseminação da informação científica e tecnológica e o trabalho colaborativo em redes, este país ainda precisa investir em projetos específicos para a $e$-Science. 


\section{FAZER CIENTÍFICO E TECNOLÓGICO}

Ao optar por falar sobre incertezas, Latour não revela apenas sua intenção de nós tragar para fora de nossa zona de conforto intelectual, pretende também desestabilizar o cientista social e retirá-lo da posição privilegiada que the permite dizer que os atores não sabem o que fazem, mas eles, cientistas, sim, sabem.

(SOUZA; SALES JÚNIOR, 2012, p. 14)

Será que os cientistas sabem realmente o que fazem? Introduzir um capítulo com uma questão dessa natureza é um tanto incomum, mas retrata o resultado de reflexões incitadas por leituras iniciais a obras do filósofo e sociólogo Bruno Latour. A impressão de que esse questionamento permeia os seus escritos fica implícita e instiga os mais curiosos pesquisadores a partir em busca de respostas.

Apesar de o assunto ter sido explorado por outros expoentes da literatura científica, Latour adiciona uma pitada de incertezas que impulsiona a investigação mais aprofundada sobre o assunto. Seu argumento é o de que tanto os atores quanto os cientistas estão intrigados por questões relativas à identidade, participação, coletivo etc. "Isso não porque os atores não saibam o que estão fazendo e os cientistas o ignorem, mas porque uns e outros precisam permanecer intrigados com a identidade dos participantes em qualquer curso de ação, caso pretendam reagregá-los." (LATOUR, 2012, p. 76). 
Somam-se às inquisições e contribuições de Latour, o fato de o fazer científico e tecnológico em si já carregar em suas entrelinhas significados, simbolismos e concepções perfazendo um misto de correntes de pensamento, controvérsias, ações, perplexidades, artefatos, agências que obrigam um debruçar parcimonioso se o objetivo pretendido é um resultado satisfatório para o entendimento dessa prática inerente à Ciência. O real entender dessa ação possibilitará a identificação das associações que cercam os atores, informantes, intermediários e mediadores envolvidos no processo e esclarecimento de alguns porquês levantados.

Ao se aprofundar um pouco mais na leitura do robusto repertório de Latour, fica evidente que a fama que lhe é atribuída de um teórico polêmico e revolucionário, não é em vão. Definitivamente, ele consegue tragar sua audiência para fora de sua zona de conforto intelectual e desestabilizar as escoras existentes nos fundamentos do fazer científico. O debruçar mais detido nos domínios da Ciência e Tecnologia encerra justamente esta intenção.

A pretensão, neste capítulo, não se enquadra em refazer minuciosa e exaustivamente a trajetória histórica e conceitual, pertinentes aos campos da Ciência e da Tecnologia. Esse foi percurso muito bem trilhado anteriormente pelos inúmeros estudiosos da Filosofia, Sociologia, História e dos mais diversos domínios do conhecimento e endossado pelos teóricos dos Estudos Sociais da Ciência ou Estudos da Ciência, ${ }^{1}$ pesquisadores responsáveis pela construção de um arcabouço literário sobre essa temática e os desdobramentos da prática científica e tecnológica na sociedade. Busca-se, contudo, neste capítulo, discorrer um pouco sobre a Ciência e a Tecnologia e trazer para a reflexão e diálogo, os fundamentos teóricos pertinentes a esses domínios do conhecimento. Pretende-se ainda resgatar especialmente o arcabouço teórico-metodológico que engloba a Teoria Ator-Rede, Actor Network-Theory (ANT), abordagem resultante de resgates e elucubrações realizadas nesse campo de estudo e um suporte conveniente para sair da zona de conforto e buscar por um entendimento do coletivo que insere os atores humanos e não humanos na pesquisa desenvolvida.

1 Estudos Sociais da Ciência, Social Studies of Science ou Estudos da Ciência, Studies of Scien$c e$, é uma linha de pesquisa que emergiu a partir de meados dos anos 70 do século XX, no mundo anglo-saxão e europeu. Está voltada para a busca de uma aproximação entre as práticas da atividade científica e as formas de organização social da pesquisa que possibilitam e auxiliam a compreensão e construção do saber (ARAÚJO, 2007). 
A apropriação dos elementos estruturantes aos quais o estudo desenvolvido estava atrelado - práticas e redes colaborativas para inovação, e-Science e políticas de fomento - foi intensificada após a assimilação dos conceitos referentes aos termos ciência e tecnologia. Um pano de fundo, diretamente intrincado ao coletivo e problemática que cercavam os eventos contemporâneos que compunham o locus da pesquisa e sua estrutura.

Salienta-se, entretanto, que o caminhar por estes domínios foi realizado sem pretender um debruçar exaustivo e minucioso, como ressaltado e sinalizado antes, por entender que essa tarefa vem sendo executada satisfatoriamente pelos especialistas e teóricos da sociologia e demais domínios, uma apropriação realizada com toda autoridade e expertise necessárias. Contudo, isto não declara a exclusividade dessa atividade a esses sujeitos e faz lembrar observações de Latour (1997) de que para se falar de Ciência não é necessário ser especialista.

O percurso realizado foi contemplado com a busca por uma interlocução e estreitamento entre o domínio destacado anteriormente e o lugar de fala de onde a pesquisa foi realizada e acolhida, a área da Ciência da Informação. Um campo do conhecimento inserido no núcleo que engloba as Ciências Sociais Aplicadas e um domínio também atrelado à análise das questões que cercam o fazer científico contemporâneo, especialmente no que tange aos insumos informacionais advindos desse fazer. Leva-se em consideração ainda a importância das aproximações realizadas entre as ideias disseminadas pelo teórico Bruno Latour, no âmbito da nova Sociologia da Ciência e trabalhos realizados na área da Ciência da Informação. Essa abertura permite a inserção de uma agenda de estudos para a melhor compreensão dos pressupostos da área. Para citar alguns desses trabalhos, destacam-se os que foram realizados por Araújo (2009a; 2009b); Araújo e Cardoso (2007); Araújo e colaboradores (2009); Mustafa (2010); Oddone (2007); França e colaboradores (2015), entre outros.

Entender para aplicar e aplicar para melhor entender, essa é a pretensão ao debruçar-se sobre este referencial teórico robusto, o qual traz vocabulário distinto e carregado de significados e metáforas responsáveis pela quebra de postulados e padrões pré-estabelecidos na comunidade científica contemporânea. 


\section{Tramas da Teoria Ator-Rede}

Ao realizar um breve resgate histórico, percebe-se que os elementos geradores e decisivos na construção, sustentação e transformação do conhecimento eram analisados, a princípio, sob o cunho filosófico e a partir do século XX, passam também a acrescentar a tutela de abordagens sociológicas, fase em que teóricos como Ludwik Fleck, Max Scheler, Karl Mannheim destacam-se e contribuem para o vislumbre de novas perspectivas para os estudos sobre a dinâmica do conhecimento (PREMEBIDA et al., 2011).

O sociólogo Robert Merton, ${ }^{2}$ considerado como criador da Sociologia da Ciência, buscou "descrever comportamentos individuais e coletivos dos cientistas, assim como o universo que os comportava (normas, hábitos sociais e profissionais, valores e ideias)." Originou-se a partir desse embrião, um conjunto de teorias que visava explicar o funcionamento da Ciência e que a promovia ao status de instituição distinta e autônoma, uma estrutura social normatizada. Dentre alguns nomes que marcaram este período destacam-se John Desmond Bernal, Joseph Ben-David, Warren O. Hagstrom e Dereck de Solla Price, entre outros (LIBERATO et al., 2014, p. 1).

As suposições teóricas que embasaram a moderna Sociologia da Ciência remetem aos estudos de inúmeros expoentes da academia, alguns desses pontuados acima. Seus insights, sobre a concepção da Ciência praticada em sua época produziram obras que foram consideradas instigadoras de ideias revolucionárias para a ordem vigente. A obra de Thomas Kuhn (2011), A estrutura das revoluções científicas, cuja primeira edição data de 1962, representa com propriedade esse período e a ela se atribui significativo destaque e associações sistemáticas com as transições ocorridas a época.

É importante registar também a contribuição de David Bloor, Barry Barnes, John Henry e Harry Collins, principais representantes da escola de Edimburgo e responsáveis por um fértil e controverso programa de pesquisa denominado Programa Forte da Sociologia do Conhecimento. ${ }^{3}$ Esse programa, a posteriori, foi alvo

2 Segundo Mathias (1976, p. xv) "deve-se a Robert K. Merton, professor de sociologia da Universidade de Columbia, a estruturação desse campo [a sociologia da ciência] como uma área definida de investigação, com seus estudos iniciados há mais de quatro décadas".

3 O programa que representou um rompimento com as ideias de Robert Merton disseminadas no âmbito dos Estudos Sociais de Ciência e Tecnologia e que se caracterizavam na época, 
de revisões e adequações propostas por Michel Collon e Bruno Latour, os quais, ao ensejarem enquadrá-lo nas equivalências por eles defendidas, desenvolveram o que a partir daí passou a se conhecer como o princípio da simetria generalizada (FERREIRA E BAPTISTA, 2009).

David Bloor, a princípio aliado de Latour, tornou-se posteriormente seu adversário devido a rupturas ocorridas no campo cientifico, ${ }^{4}$ principalmente devido a divergências quanto ao princípio da simetria. Em artigo de Odonne (2007) resgata-se um resumo do programa forte apresentado por Barnes, Bloor e Henry, o qual carrega pressupostos teóricos bastante radicais do ponto de vista epistemológico tradicional, segundo seus articuladores, como se pode constatar a seguir. Esse programa, assim como alguns postulados de Robert Merton, instigou aos criadores da ANT a refletir e propor uma alternativa para a sociologia tradicional ou sociologia do social como era comumente denominada por Latour.

- a ciência é uma atividade humana como qualquer outra, sendo social e historicamente determinada;

- a ciência enquanto fenômeno cultural deve ser compreendida em relação aos contextos em que ocorre;

- o produto da ciência afeta a sociedade na mesma medida em que é por ela afetado;

- o que chamamos de conhecimento científico é um produto socialmente construído, negociado e aplicado;

- as investigações sobre a ciência devem levar em conta, simultaneamente, suas formas institucionais, seus usos sociais, suas práticas e também seu conteúdo;

- a sociologia da ciência deve ser imparcial, ou seja, deve tomar como objeto a ser explicado tanto o quanto se julga ser verdadeiro quanto o que se crê ser falso, tanto o racional quanto o irracional;

pelo estudo da estrutura, da mudança e organização da comunidade científica, da cientometria e do papel dos cientistas na sociedade (PREMEBIDA et al., 2011; LEMOS, 2013). Para maiores detalhes sobre o Programa Forte da Sociologia do Conhecimento consultar Bloor (1976).

4 Divergências suscitadas com relação à visão de cada um quanto ao princípio da simetria. Detalhes podem ser obtidos em Bloor (1999) e Latour (1997; 1999). 
- a sociologia da ciência deve oferecer aos fenômenos que observa explicações simétricas, ou seja, que esclareçam tanto os seus aspectos positivos quanto os negativos;

- a sociologia da ciência deve ser reflexiva, ou seja, os padrões de explicação que ela adota para seus objetos devem, identicamente, ser aplicados a ela própria (ODDONE, 2007, p. 117).

A ANT, resultado do amadurecimento das proposições e reflexões ensejadas no âmbito da nova Sociologia da Ciência e uma busca por fazer um contraponto com as ideias vigentes, foi desenvolvida nos idos da década de 1980, pelo filósofo e sociólogo francês Bruno Latour e pesquisadores como Michael Collon, John Law, Madeleine Akrich, entre outros. Essa teoria é também conhecida como Sociologia de Associações, Sociologia da Tradução, Sociologia da Inscrição ou Sociologia de Translação e contrapõe-se ao que Latour (2012) denomina de Sociologia Crítica e Sociologia do Social. Ao definir a ANT, Latour (2012) sinaliza para sua origem e motivação ao pontuar que ela emergiu da Sociologia da Ciência ao tirar conclusões extremas não só para a ciência, mas também para a teoria do social, e complementa ao dizer que:

A ANT não é um ramo da ciência social que conseguiu estender seus métodos à atividade científica e depois ao resto da sociedade, mas sim o ramo (ou antes, o broto) composto por aqueles que haviam ficado totalmente abalados quando tentaram dar uma explicação social dos fatos intrincados da ciência. Os estudiosos da ANT são definidos principalmente como aqueles que dos trinta e tantos anos da sociologia da ciência tiraram uma conclusão totalmente diferente das dos seus melhores e mais caros colegas (LATOUR, 2012, p. 139, grifo do autor).

O arcabouço teórico sob o qual a ANT foi construída possuiu influências diversas tendo sido algumas já citadas anteriormente. Contudo, Lemos (2013, p. 34, grifo do autor) complementa este referencial e sinaliza como as mais reconhecidas,

o pós-estruturalismo, a 'semiótica material' de Foucault, os conceitos de agenciamento, rede e topologia de Deluze e Guattari, as ideias de tradução, sujeito, objeto, espaço e 
tempo de Michael Seres, a etnometodologia de Garfinkel e a sociologia de Gabriel Tarde.

Dentre as muitas influências que a ANT sofreu durante o seu desenvolvimento, destaca-se a de Gabriel Tarde. Latour (2012) indica este autor como um precursor alternativo para uma teoria social alternativa e um pensador crente no que poderia tornar-se a Sociologia, como se reproduz a seguir:

[...] na galeria de retratos dos predecessores eminentes, ele é um dos poucos que, com Harold Garfinkel, acreditava na possibilidade de a sociologia tornar-se uma ciência apta a explicar como a sociedade é mantida, em lugar de usar a sociedade para justificar outra coisa ou ajudar a resolver os problemas sociológicos do social (LATOUR, 2012, p. 34).

Essa teoria impulsionou a objeção aos pressupostos sob os quais a Sociologia Clássica estava assentada e trouxe para a discussão elementos que representavam a ressignificação do objeto de estudo e dos métodos utilizados. Reis (2010) ainda complementa, ao acrescentar:

Diferentemente da sociologia do 'social', a sociologia das 'associações' proposta por Latour não vê o 'social' como um domínio específico, distintos de outros - econômico, político, técnico, etc - ou como uma propriedade de certos fenômenos (o famoso facto social durkheimiano) mas como o resultado de coisas, ou entidades, como ele prefere chamar-lhes, humanas e não humanas, que ao estarem encadeadas e conectadas de formas precisas e rastreáveis se tornam, neste e só neste sentido, sociais.

Com sua contribuição Latour (2012, p. 13) retira da Sociologia do 'Social' “[...] a segurança da imutabilidade de seu objeto de estudo bem como as fórmulas que se deve empregar para melhor explicá-lo." Afirma ainda que "poucos cientistas sociais chegaram à conclusão extrema de que tanto o objeto quanto a metodologia das ciências sociais" deviam ser modificados. A necessidade de uma nova teoria do social ajustada aos Estudos de Ciência e Tecnologia foi o que deu ori- 
gem a essa abordagem conforme pontua. Sua intenção não era desmentir nem provar que as outras teorias sociais estavam erradas, mas sim fazer propostas.

Como um dos principais responsáveis pela mudança no olhar sobre a forma do fazer científico e tecnológico contemporâneo, Latour tem o pensamento descrito por Carrara (2002, p. 180) "como uma tempestade de verão [...] parece ser ao mesmo tempo esperado e temível, previsível e surpreendente." Um autor contemporâneo com tradição construtivista, por privilegiar a interação entre o discurso científico e a sociedade, preocupado com os desdobramentos da atividade científica.

Questionamentos diversos sobre a sociedade, e o termo "social", como pontuados acima, levaram Latour (2012) a propor alternativas que passariam a contribuir para a renovação dos postulados estabelecidos na sociologia tradicional.

[...] penso estar na hora de modificar o que se entende por 'social'. Quero, pois encontrar uma definição alternativa para 'sociologia' sem descartar esse rótulo útil e continuando fiel, assim espero, a seu apelo tradicional. [...] Ainda que a maioria dos cientistas sociais prefira chamar 'social' a uma coisa homogênea, é perfeitamente lícito designar com o mesmo vocábulo uma série de associações entre elementos heterogêneos. Dado que, nos dois casos, a palavra tem a mesma origem - a raiz latina socius - podemos permanecer fieis às instituições originais das ciências sociais redefinindo a sociologia não como a 'ciência do social', nas como a busca de associações. Sob esse ângulo, o adjetivo 'social não designa uma coisa entre outras, como um carneiro negro entre carneiros brancos, e sim um tipo de conexão entre coisas que não são, em si mesmas, sociais (LATOUR, 2012, p. 19-23, grifo do autor).

5 Em Latour (2012, p. 24-123-158, grifo do autor) o significado do termo "social" é esmiuçado e apresenta a tendência etimológica nas múltiplas variações semânticas. Ele complementa ainda que este termo "significa tanto interações locais diretas, transitórias demais para explicar assimetrias, quanto um apelo mágico a forças tautológicas cujo preço exato em termos de carga material", os sociólogos do social, nunca se dispuseram a pagar. "O social não está em lugar nenhum em particular como uma coisa entre outras coisas, mas pode circular em qualquer lugar como um movimento que liga coisas não sociais, ou seja, uma associação." 
Para a ANT, como enfatiza Latour (2012, p. 99) a definição do termo "social" não é a comumente apreendida, ela é outra, não designa um domínio da realidade ou um item especial, ela "é antes o nome de um movimento, um deslocamento, uma transformação, uma translação, um registro. É uma associação entre entidades de modo algum reconhecíveis como sociais no sentido corriqueiro, exceto durante o curto instante em que se confundem." Ou seja, "é o nome de um tipo de associação momentânea caracterizada pelo modo como se aglutinam assumindo novas formas."

A concepção da ANT pode ser traduzida como a tentativa de "achatar" o mundo social para torná-lo o mais visível possível, facilitando um olhar cuidadoso sobre os tipos de agregados e sua forma de conexão. Como destaca Latour a seguir quando indica suas estratégias para a construção da ANT.

Tomando uma metáfora da cartografia eu diria que a ANT procurou tornar o mundo social o mais achatado possível para garantir a total visibilidade de qualquer vínculo novo, [...] já é tempo de olhar com mais cuidado o tipo de agregados até agora reunidos e os modos como eles se conectam uns com os outros (LATOUR 2012, p. 37, grifo do autor).

O rastreamento das conexões entre as controvérsias e a não tentativa de tomar a decisão de como solucioná-las é a recomendação de Latour (2012) para um caminhar ordeiro com a utilização da ANT, sem tentativas de interromper seu fluxo. Cabe aos atores a tarefa de ordenamento e definição do social. A abordagem de Latour na ANT, como Araújo e colaboradores (2009, p. 137) complementam, é "uma análise crítica e interdisciplinar da ciência e da tecnologia em contexto social, tendo por objetivo a compreensão dos aspectos gerais do fenômeno científico-tecnológico." Ela repercute na sociedade e influencia os pesquisadores que se debruçam sobre os Estudos Sociais da Ciência e campos afins. Eles acrescentam ainda que para Bruno Latour e outros pensadores da ANT, “[...] o conhecimento é um produto social, mais do que algo gerado a partir da operação de um método científico privilegiado, e que tal conhecimento (generalizado) pode ser visto como um produto ou um efeito de uma rede de materiais heterogêneos". 
A existência de uma simetria entre as causas dos fatos científicos tratando de modo equivalente ao verdadeiro e falso, ao científico e social é um diferencial na visão atribuída à nova Sociologia da Ciência. Entretanto, de modo apropriado, Ferreira e Baptista (2009) complementam que este princípio "não quer dizer a anulação da diferença entre os seres, mas apenas considera a possibilidade de que os agenciamentos implicados nas redes possam ser analiticamente equivalentes.”

O reducionismo e a assimetria é uma das causas do fracasso nas tentativas de superação dos abismos existentes na sociologia clássica e Carrara (2002, p. 182) resgata o pensamento de Latour sobre esse aspecto quando ele afirma que as tentativas realizadas até hoje com a intenção de superar o abismo existente entre os homens e as coisas, oriente e ocidente, primitivos e civilizados fracassaram e terminaram por aprofundar ainda mais a separação contra a qual aparentemente se insurgiram. Ainda sobre o principio da simetria, Latour (2012, p. 114, grifo do autor) é enfático ao afirmar que:

A ANT não é - repito: não é - a criação de uma absurda 'simetria entre humanos e não humanos'. Obter simetria, para nós, significa não impor a priori uma assimetria espúria entre ação humana intencional e mundo material de relações causais. Existem divisões que não devemos ultrapassar, superar, reduzir dialeticamente. Elas precisam, isto sim, ser ignoradas e abandonadas a seus próprios recursos, como um castelo outrora formidável e hoje em ruínas.

Interpretações diversas são atribuídas à ANT no vasto repertório literário que ela derivou; Ryder (2016, tradução nossa) as sistematizou e resgata as impressões de autores dos mais variados domínios do conhecimento. Destacam-se a seguir alguns trechos de suas considerações:

Bernard Frohmann - [A] metodologia rica da ANT abarca a análise do discurso, construtivismo social e realismo científico em seu conceito central de híbridos, ou 'quase-objetos', que são simultaneamente discursivo, social e real. Desenvolvida como uma análise de artefatos científicos e tecnológicos, a riqueza teórica da ANT deriva de sua recusa em reduzir explicações para cada categoria discursiva, social e natural embora reconheça o significado de cada uma; 
Thierry Bardinia - [A] Teoria Ator-Rede (ANT) evoluiu a partir da obra de Michel Collon (1991) e Bruno Latour (1992) na École des Mines de Paris. Suas análises de um conjunto de negociações descreve a constituição progressiva de uma rede em que tanto atores humanos quanto não humanos assumem identidades de acordo com as estratégias de interações predominantes. [...] A mais importante dessas negociações é a 'tradução', uma interação multifacetada em que atores: (1) constroem definições e significados comuns, (2) definem representatividades e (3) cooptam entre si na busca de objetivos individuais e coletivos. Na Teoria Ator-Rede, ambos os atores e actantes compartilham a ação na reconstrução da rede de interações que conduzem a estabilização do sistema. Mas a diferença fundamental entre eles é que somente os atores são capazes de colocar actantes em circulação no sistema.

Josepj Groguen - Teoria ator-rede pode ser vista como uma forma sistemática para trazer a infraestrutura que é geralmente deixada de fora das contas 'heroicas' de realizações científicas e tecnológicas.

Lars Risan - no que eles têm chamado uma 'teoria de rede' [Latour e Callon] desenvolvem um vocabulário que torna a distinção entre objetos e sujeitos, objetivo e subjetivo, em consideração. O que eles chamam de 'atuante', por exemplo, é mais do que um ator humano. Ambos humanos e não humanos podem ser actantes. Um actante pode ser associado como aliado para dar força na posição. [...] Em redes de humanos, máquinas, animais, e de significados em geral, humanos não são os únicos com mediação, não são os únicos a agir; explicar significados.

Jay Lemke - ANT observa que a topologia das redes é em geral, não local, e ainda que os artefatos semióticos sejam muitas vezes os 'objetos de fronteira' que medeiam interconexões de quebra de escala não locais.

Bowker e Star - Latour, Callon e outros dentro da abordagem ator-rede desenvolveram uma matriz de conceitos, a fim de descrever o desenvolvimento e operação da tecnociência. Seus conceitos valiosos incluem: regimes de delegação; a centralidade da mediação; e a posição de que a natureza e a sociedade não são causas, mas as consequências do trabalho científico e técnico humano. 
Nancy Van House - Teoria ator-rede (ANT) está preocupada com os processos pelos quais as controvérsias científicas tornam-se fechadas, ideias aceitas, ferramentas e métodos adotados - isto é, com a forma como decisões são tomadas sobre o que é conhecido.

A apreensão dos conceitos inclusos no repertório da ANT não é tarefa fácil chegando até mesmo a torná-la em certas circunstâncias, inaceitável. Resgata-se esse repertório, vasto e rico em acepções originais e metáforas tomadas de empréstimo de outros domínios no decorrer da pesquisa desenvolvida. A escolha de Latour (2012, p. 52) por esse vocabulário é justificada quando ele diz: "preferi um vocabulário mais geral, mais banal e mesmo mais vulgar, pois assim não há risco de confundi-lo com o idioma tão prolífico dos próprios atores." Para a apropriação adequada do seu significado ao contexto de análise é necessário um se debruçar sobre a linguagem utilizada e uma compreensão verdadeira desses termos.

A infralinguagem ${ }^{6}$ é a que a ANT utiliza; uma linguagem que não possui outro sentido além do de permitir o deslocamento de um quadro de referência a outro. Alguns desses termos são pontuados, antes do mergulho nas infindáveis propostas da ANT, pois seu significado deve ser apreendido à medida que a apropriação se faz crescente e o entendimento toma o lugar da ignorância. Eles aparecem sistematicamente nas obras de Latour e ganham sentido à medida que são inseridos e absolvidos pelo contexto analisado. São eles: ator, actante, rede, caixa-preta, centros de cálculos, intermediários, mediadores, informantes, figuração, tradução, inscrição, problematização, entre outros que recheiam o vocabulário de Latour. Ressalta-se, contudo, que, desses termos, a palavra rede, não se enquadra na motivação que ensejou a escolha dos outros vocábulos, ou seja, na falta de significado, entretanto, ela tem significados demais, como pontua o próprio Latour (2012).

6 Infralinguagem quer dizer um conjunto de termos que, por nada significarem "podem ser mobilizados para a explicação do edifício teórico: grupo (em vez de sociedade), associação (em vez de social), 'actants' em vez de sujeito, e por aí em diante. O aprendiz de ANT cedo perceberá que noções como contexto, estrutura, reprodução social, níveis macro e micro, episteme, campo, vão sendo meticulosa e impiedosamente retirados de cena pela pena de Latour. Em seu lugar surge esplendorosa e reluzente, a ANT e o seu jargão: mobilização, transladação, híbridos, redes, cadeias, centros de cálculo." (REIS, 2010). 
Ao sistematizar as cinco grandes incertezas que caracterizam as controvérsias mais relevantes da ANT Latour (2012) trabalha com as principais instituições das ciências sociais e apresenta, de uma maneira original, como elas compõem esse universo. Com essa apresentação, como ele destaca, busca-se facilitar a compreensão do leigo e permitir a introdução não tradicional aos caminhos das Ciências Sociais.

Atribui-se às incertezas o motivo pelo qual a ANT é tida como implausível e Latour recomenda ainda que elas devem ser empilhadas umas sobre as outras para que cada uma delas torne a anterior ainda mais intrigante até que se alcance algum sentido comum. Elas são enumeradas a seguir e detalhadas um pouco mais no transcorrer desta seção.

- a natureza dos grupos: há várias formas contraditórias de se atribuir identidade aos atores;

- a natureza das ações: em cada curso de ação, toda uma variedade de agentes parece imiscuir-se e deslocar os objetos originais;

- a natureza dos objetos: o tipo de agências que participam das interações permanece, ao que tudo indica, aberto;

- a natureza dos fatos: os vínculos das ciências naturais com o restante da sociedade parecem ser constantemente fonte de controvérsias;

- finalmente, o tipo de estudos realizados sob o rótulo de ciência do social, pois nunca fica claro em que sentido exato se pode dizer que as ciências sociais são empíricas (LATOUR, 2012, p. 42, grifo nosso).

Ao se ater a primeira fonte de incerteza - a natureza dos grupos - Latour (2012) afirma que não há grupos, apenas formação de grupos. A recuperação da ideia de associação é o viés predominante, agregado à difícil proposta de se desfazer do social como domínio da realidade. Ele acrescenta que, se para os sociólogos, o primeiro problema parece determinar um grupo privilegiado, para ele a experiência ensina que existem inúmeras formações de grupos e alistamentos em grupos contraditórios. A opção é clara para os que desejam enveredar nessa investigação: ou seguir os teóricos sociais, ou adotar o exemplo dos atores e sair pelo mundo rastreando as pistas deixadas no processo de formação e desmantelamento dos grupos. Como ele reafirma "a primeira fonte de incerteza com a 
qual devemos aprender é que não há grupo relevante ao qual possa ser atribuído o poder de compor agregados sociais, e não há componente estabelecido a ser utilizado como ponto de partida incontroverso." (LATOUR, 2012, p. 51).

A inclusão como porta-voz da definição durável de grupos, atribuída a quatro, entre os muitos porta-vozes existentes - os cientistas sociais, as ciências sociais, a estatística social e o jornalismo social - apresenta-se como diferença essencial entre as duas escolas de pensamento, como se destaca a seguir.

Essa é uma das diferenças essenciais entre as duas escolas de pensamento. Para os sociólogos do social, a sociologia deve insistir em tornar-se uma ciência no sentido tradicional e desinteressado de um olhar dirigido ao mundo exterior, o que possibilitará uma descrição até certo ponto independente dos grupos materializados pelos atores. Para os sociólogos de associações, qualquer estudo de qualquer grupo por qualquer cientista integra aquilo que faz o grupo existir, durar, decair ou desaparecer. [...] Se, na primeira escola, atores e estudiosos estão em barcos separados, na segunda permanecem num só o tempo todo e desempenham o mesmo papel, ou seja, formação de grupos. Para agrupar o social, a colaboração de todos é necessária. [...] Para os sociólogos do social, a ordem é a regra; a decadência, a mudança ou a criação são exceções. Para os sociólogos de associações, a regra é a performance e aquilo que tem de ser explicado, a exceção perturbadora, é qualquer tipo de estabilidade a longo prazo e em larga escala. É como se, nas duas escolas, frente e fundo se invertessem (LATOUR, 2012, p. 58, 60, grifo do autor).

Os meios utilizados para produção do social possuem grande diferença, a depender de como são encarados, se como intermediários ou como mediadores. Esses são dois dos poucos termos técnicos utilizados por Latour, os quais carregam o poder de influenciar nessa produção e conduzir a territórios diferenciados. Os intermediários, transportam significado e força sem transformar e os mediadores ao contrário, transformam, traduzem, distorcem e modificam o significado ou os elementos que supostamente veiculam. A "constante incerteza quanto à natureza íntima das entidades - elas se comportam como intermediários ou mediadores ?" é a fonte de todas as outras incertezas. Quando os 
meios ou ferramentas usados na construção são encarados como mediadores, a verdadeira diferença entre a sociologia do social e a sociologia das associações torna-se visível. "A distinção infinitesimal entre mediadores e intermediários é que produzirá, no fim, todas as diferenças de que precisamos entre os dois tipos de sociologia." (LATOUR, 2012, p. 64-67).

A segunda fonte de incerteza - a natureza das ações - ainda mais importante e que está no âmago de todas as ciências sociais, como descreve Latour (2012, p. 72), vê a ação como algo transcendente. "A ação não ocorre sob o pleno controle da consciência; a ação deve ser encarada, antes, como um nó, uma ligadura, um conglomerado de muitos e surpreendentes conjuntos de funções que só podem ser desemaranhados aos poucos." A expressão ator-rede, considerada uma “expressão bizarra” por Latour, retrata a venerável fonte de incerteza contemplada. Ao utilizar o termo "ator" ele pega emprestado seu sentido simbólico retirado de um cenário fictício e o emprega na representação ampliada que pretende atribuir ao "ator" da ação. Sem uma identificação fixa pode ser atribuído tanto a humanos como a não humanos, como ele mesmo justifica.

O 'ator', na expressão hifenizada 'ator-rede', não é a fonte de um ato e sim o alvo móvel de um amplo conjunto de entidades que enxameiam em sua direção. [...] . Empregar a palavra 'ator' significa que jamais fica claro quem ou o quê está atuando quando as pessoas atuam, pois o ator, no palco, nunca está sozinho ao atuar (LATOUR, 2012, p. 75).

Ao continuar seu discurso sobre a mobilidade da ação, Latour (2012, p. 76) ainda complementa, que essa não é local e, sim, deslocada, podendo ser tomada de empréstimo, distribuída, sugerida, influenciada, dominada, traída, traduzida. A expressão ator-rede "representa a principal fonte de incerteza quanto à origem da ação", ou seja, o seu deslocamento. As ações, como ele acrescenta, "são parte de um relato: possuem uma figura qualquer; opõem-se a outras ações rivais; e, por fim são acompanhadas por uma teoria explicita da ação."

O desejo de explicar as assimetrias com as quais a sociologia do social é marcada, fundamenta a intenção de Latour (2012, p. 98) em não querer repeti-las e muito menos transportá-las sem modificação alguma. Ele afirma e questiona que "não há como negar que as assimetrias existem; mas de onde vêm e de que 
são constituídas? A "fé" nas Ciências Sociais foi a justificativa para a busca por respostas e pelos posicionamentos radicais tomados pelos sociólogos de associações, como afirma Latour (2012, p. 98, grifo do autor).

Foi porque quiseram manter a intuição original nas ciências sociais que precisaram rejeitar inapelavelmente a solução impossível de que a sociedade é desigual e hierárquica; de que exerce um peso desproporcional em algumas partes; e de que tem todas as características da inércia. Dizer que a dominação viola corpos e almas é uma coisa; ao passo que conclui que hierarquias, dissimetrias, inércia, poderes e crueldades são compostos de material social é um argumento totalmente diferente. O segundo ponto não apresenta continuidade lógica com o primeiro e além de tudo está, como veremos, em absoluta contradição com ele.

A natureza dos objetos é a fonte de investigação da terceira incerteza e nela destaca-se a ação dos objetos salientando-se que eles também agem. A indagação a respeito da origem dessa ação é a melhor forma de entendê-la. A reposição de objetos no curso normal da ação pode parecer inócuo, diz Latour (2012), mas o que na verdade os impedia de desempenharem papéis, era também a definição de atores e ações geralmente escolhidas e não apenas a definição de social dada pelos sociólogos. Assim, resgata-se a segunda fonte de incerteza e o destaque recai sobre a natureza da ação como preponderante no ato. A fonte de ocorrência da ação define o alcance e transforma sua validade dos objetos. A intenção ou significado atribuído ao ato humano não se coadunam com a ação de objetos tais como um martelo, um cesto etc. Entretanto, a subjetividade e mutabilidade da situação de forma ativa e diferenciada transformam os atores e os atos como consequência da ação dos objetos porque eles agem também e resgatam a ideia de rede e associações, de humanos e não humanos. Latour (2012, p. 108, grifo do autor) enfatiza ainda que,

Se a ação se limita ao que os humanos fazem de maneira 'intencional' ou 'significativa', não se concebe como um martelo, um cesto, uma fechadura, um gato, um tapete, uma caneca, um horário ou uma etiqueta possam agir. Talvez existam no domínio das relações 'materiais' e 'causais', mas não na esfera 'reflexiva' ou 'simbólica' das 
relações sociais. Em contrapartida, se insistirmos na decisão de partir das controvérsias sobre atores e atos, qualquer coisa que modifique uma situação fazendo diferença é ator - ou, caso ainda não tenha figuração, um actante.

O papel desempenhado pelas coisas é veementemente enfatizado quando Latour (2012, p. 109) acrescenta que "além de 'determinar' e servir de 'pano de fundo' para a ação humana, as coisas precisam autorizar, permitir, conceder, estimular, ensejar, sugerir, influenciar, interromper, possibilitar, proibir etc." Ele ainda ressalta que a ANT não alega, sem base, que os objetos fazem coisas 'no lugar' dos atores humanos, ela diz apenas que nenhuma Ciência do social pode existir se a questão de "o quê" e "quem" participa da ação não for logo de início plenamente explorada, embora isso signifique descartar elementos que, à falta de termo melhor, chamam-se de não humanos. É importante a explicação de Latour sobre esse vocábulo, assim como de outros que utiliza no decorrer de sua obra. A interpretação errônea do sentido em que emprega esses termos pode ser considerada, em alguns casos, o motivo para a indevida interpretação da teoria. Latour (2012, p. 109) deixa claro que "essa expressão, como outras escolhidas pela ANT, não tem significado em si mesma. Não designa um domínio da realidade." Ao ampliar a lista e modificar as formas e figuras dos atores, o projeto da ANT evidencia que o modo do fazer científico é reconfigurado e o agir desses participantes torna-se mais durável e surpreendente.

A discussão sobre a quarta fonte de incerteza - a natureza dos fatos - é introduzida por Latour (2012) ao se reportar ao início da ANT, resgatando sua origem e apresentando retificações necessárias utilizadas como um recurso para fazê-la compreensível em seu exato significado, especialmente para os seus "melhores amigos." Essa tentativa fica evidente na referência à importância do subcampo Estudos da Ciência, Science Studies, para a renovação e ressignificação de palavras-chave para a área, tais como, fato, ciência, construção e social e sua inserção no mundo que perpassa a ciência e a tecnologia. A esse campo e ramos similares à ciência social, Latour (2012, p. 147) atribui a responsabilidade de "remover o padrão que os tornava por comparação, marginais ou meramente especiais."

7 Expressão irônica utilizada por Latour (2012) ao se referir aos críticos às ideias disseminadas pela nova sociologia da ciência. 
Latour realizou um passeio ao domínio sociológico ao discutir problemas por ele nomeados como questões de fato e questões de interesse e detalhar a construção de um fato científico. O mapeamento das controvérsias científicas sobre questões de interesse foi o que permitiu, conforme Latour (2012), uma plena renovação. Ao explicar o sentido da expressão construtivismo social, ele percorre um caminho que esclarece as diversas acepções ao termo construção, aliando-o ao sentido que é proposto pela ANT ao termo social. Ele enfatiza que não se deve confundir construtivismo com construtivismo social e ainda explica:

quando dizemos que um fato é construído, queremos dizer simplesmente que explicamos a sólida realidade objetiva mobilizando entidades cuja reunião poderia falhar; construtivismo social significa, por outro lado, que substituímos aquilo de que essa realidade é feita por algum outro material - o social de que ele "realmente" é feito. Uma explicação sobre a gênese heterogênea de um edifício é substituída por outra que trata da matéria social homogênea da qual ele é construído. Para reconduzir o construtivismo às suas bases, basta ver que, como social significa novamente associação, a ideia de uma construção feita de matéria social desaparece. Para ocorrer qualquer construção, as entidades não humanas têm de desempenhar um papel maior, e é exatamente isso que queríamos dizer desde o começo com esse termo um tanto inócuo (LATOUR, 2012, p. 135-36, grifo do autor).

As colocações de Latour e demais pesquisadores da ANT suscitaram tamanho rebuliço tamanho no cerne das ciências sociais e demais domínios que se sentiram alvo das críticas por eles apresentadas e foram capazes de gerar uma batalha intelectual denominada comumente como "Guerra de Ciências". ${ }^{8} \mathrm{~A}$ interpretação de Latour com relação a esse episódio deixa evidente o espaço que se abriu para a reflexão dos sociólogos das associações e a compreensão de que não

8 A utilização da expressão "Guerra de Ciências" é explicada por Latour (2012) como uma referência à reação dos cientistas aos Estudos da Ciência, em que eram usados como foco de investigação. Ele ressalta ainda que ocorreu um intervalo de vinte anos entre o começo dos verdadeiros Estudos de Ciência e as críticas e manifestações dos "guerreiros da ciência". Em uma crônica publicada na Folha de São Paulo, Latour (1998) fala sobre os questionamentos e as verdades universais que colocaram em xeque o saber tradicional e suscitaram a Guerra das Ciências. 
havia a menor possibilidade de que o tipo de forças sociais que usavam como causa poderiam ter os fatos objetivos como seus efeitos. Esse momento ficou registrado no resgate que Segata (2012) realizou da via que foi aberta entre os pesquisadores dos Estudos da Ciência e os críticos a suas concepções. O resultado foi inusitado, mas rico para o entendimento de que gerou novas colocações sobre a pretensão da ANT, como é destacado:

Se foi interessante os Science Studies denunciarem que a gravidade ou o vácuo estudados por físicos eram construções (modelos da realidade) fabricados pelos próprios cientistas - ou seja, eram feitos ao invés de fatos - mais interessante ainda foi, a partir deles, perceber que o social também era (é) uma construção do sociólogo - um feito (e por [que] não, um fetiche) ou modelo de realidade (SEGATA, 2012, p. 241, grifo do autor).

A quinta e última fonte de incerteza - o tipo de estudos realizados - foi apresentada por Latour (2012) como uma chance para a resolução das controvérsias até então mencionadas e reforça a decisão de alimentar incertezas como um recurso obstinado para superar as dificuldades do percurso. Ao se debruçar sobre a atividade do ato de escrever, Latour é enfático em afirmar que escrever textos requer comprometimento e entrega, o que fica subentendido com a frase "Escrevemos textos, não ficamos olhando através da vidraça de alguma janela".

$\mathrm{O}$ saldo de sua viagem por esse mundo permite ao leitor, o qual vivencia o momento descrito, enquadrar-se em alguma das situações postas e experimentar uma identificação instantânea. Ele pontua que "a ideia é simplesmente trazer para o primeiro plano o próprio ato de compor relatos" e complementa que "a diferença não está entre aqueles que sabem com certeza e aqueles que redigem textos, entre mentes 'científicas' e mentes 'literárias', [...] mas entre quem escreve maus textos e quem escreve textos bons.” (LATOUR, 2012, p. 180-183). Um bom relato para Latour é como aquele que tece uma rede, ou seja, uma série de ações em que cada participante é tratado como um mediador completo. Em outras palavras, de modo mais simples,

[...] um bom relato ANT é uma narrativa, uma descrição ou uma proposição na qual todos os atores fazem alguma 
coisa e não ficam apenas observando. [...] A melhor maneira de ir adiante e abordar a quinta fonte de incerteza é simplesmente não perder de vista todos os nossos movimentos, mesmo aqueles que se referem à própria produção do relato (LATOUR, 2012, p. 189,195).

Ao debruçar-se sobre as fontes de incertezas esmiuçadas por Latour (2012) pretendeu-se, ao identificá-las no trabalho apresentado, agregar à nova Sociologia da Ciência, a área da Ciência da Informação e a Nanotecnologia. Cientes das limitações existentes com a utilização da metodologia, especialmente pelo fato de a pesquisa que foi realizada não pretender desenvolver um tratado sociológico ou antropológico dos atores observados. Almeja-se, sim, com um ferramental próprio da ANT e da Ciência da Informação debruçar-se sobre os insumos produzidos pela Nanotecnologia e identificar a repercussão de sua ação na produção do conhecimento científico e a consolidação das suas redes colaborativas.

A preocupação presente sempre foi atribuir sentido ao aprendizado sem contudo fugir em demasiado nem das fronteiras dos domínios da Ciência da Informação nem da Nanotecnologia. A alternativa encontrada é como Latour recomenda seguir os pesquisadores e as "coisas" em seu entrelaçamento e, a partir dai, descobrir em que a existência coletiva se transformou e que métodos foram utilizados para esta construção. 


\section{NANOTECNOLOGIA E SUA IMPORTÂNCIA NO CONTEXTO BRASILEIRO}

Demoramos muito tempo para aprender que tudo na natureza é feito de átomos, agora estamos aprendendo a fazer tudo a partir dos átomos.

$\left(\right.$ Cylon Silva) ${ }^{1}$

A Ciência e a Tecnologia desempenham um papel transformador na sociedade. A Nanociência e a Nanotecnologia $(\mathrm{N} \& \mathrm{~N})$ possuem papéis semelhantes e não menos transformadores. A sugestão de que estes termos sejam fundidos e passem a ser denominados de nanotecnociência é uma prerrogativa que Schulz (2008) apresenta. São campos emergentes da atividade científica e atuam com a manipulação de estruturas em esferas nanométricas ${ }^{2}$ como as moléculas e os átomos. Entretanto, têm causado na sociedade contemporânea imensa repercussão, por representarem respectivamente o estudo e a aplicação tecnológica realizadas em escala nanométrica.

A Nanociência e a Nanotecnologia são associadas a termos como revolução invisível, miniaturização de estruturas, revolução industrial, admirável mundo novo, ficção científica, ciência e tecnologia dos materiais, entre ou-

1 A autoria desta frase é atribuída a Cylon Gonçalves da Silva conforme Shulz (2008, p. 2).

2 A escala nanométrica refere-se à medida que tem por base o nanômetro $(\mathrm{nm})$ que equivale à bilionésima parte de um metro. 
tros. Dos materiais produzidos com a aplicação da nanotecnologia derivam estruturas como: cristais sintéticos diversos, desde diamantes até os cristais de silício com os quais se fabricam os chips dos computadores; materiais magnéticos para gravação e armazenamento de dados; ligas diversas para a indústria mecânica; materiais plásticos e vítreos; e ainda grande variedade de materiais com propriedades específicas e otimizadas para aplicações industriais diversas (CHAVES, 2002).

A meta de dominar parte, pequena que seja, do virtuosismo da natureza na organização da matéria átomo por átomo, molécula por molécula é atribuído à $\mathrm{N} \& \mathrm{~N}$, como destaca Chaves (2002). Apesar do caráter de atualidade que encobre os estudos na área, desde a antiguidade existem indícios da suspeita da existência de estruturas bem pequenas, as nanoestruturas. Essa é uma observação que Santos Junior (2011, p. 23, grifo do autor) resgata ao se referir a N\&N e destacar sua importância no campo científico.

Estamos falando como já apontado [...] da nanociência e da nanotecnologia, que aparecem como o mais amplo salto em direção ao controle e à manipulação de átomos, antigo sonho de muitos cientistas e que já foi capítulo de alguns 'contos de fadas científicos'.

Vale lembrar que desde os tempos de Leucipo de Mileto e Demócrito de Abdera (séc V a.C.) já havia uma suspeita de que a matéria era composta de pequenas estruturas que seriam a sua parte indivisível. Ao contrastar a aparência de um tronco de árvore com as cinzas (produto de uma mesma unidade - a árvore), os atomistas gregos não encontraram nada em comum. Intuíram, então, a existência de uma estrutura capaz de explicar a relação entre os dois elementos. Daí provém o nome átomo, ou melhor, á-tomo, ou seja, aquilo que não pode mais ser quebrado ou dividido em partes.

Resgates outros sobre a utilização de nanopartículas em lugares e contexto histórico passado são pontuados também por Ferreira e Rengel (2009, p. 1861), conforme descreve-se a seguir: 
Os chineses, embora sem ter consciência disso, já aplicavam a nanotecnologia, ao empregarem nanopartículas de carvão em solução aquosa para produzir a tinta nanquim. $\mathrm{Na}$ Europa, o colorido dos vitrais das igrejas medievais, tão ricamente trabalhados pelos artesões, era o resultado da formulação do vidro com nanopartículas de ouro. A famosa Taça de Licurgus, do século IV d.C, que exibe uma cor verde quando a luz é refletida, mas é vermelha sob luz transmitida, é na realidade constituída por nanopartículas de ouro e prata.

A invenção do microscópio de varredura por tunelamento, Scanning Tunneling Microscope (STM), em 1981, por Gerd Binning e Heinrich Roher, do laboratório da IBM em Zurique é considerado como um dos feitos mais importantes para o desenvolvimento da N\&N (CHAVES, 2002). Esse equipamento permite a visão e manipulação das nanoestruturas, um grande passo que impulsionou o deslanchar de uma área emergente, com inserção em vários segmentos da sociedade, um impacto científico e econômico crescente para a população mundial.

Algumas áreas de inserção da Nanotecnologia são pontuadas de modo resumido na Figura 6, e permite vislumbrar a dimensão das aplicações e frentes de atuação que a área congrega. Fica evidente a interdisciplinaridade presente e a contribuição que essa diversidade representa em termos de benefícios para a sociedade. Medicina, Química, Física, Engenharia, Biologia e Informática são apenas alguns exemplos de seu escopo de abrangência.

A prática científica realizada por campos do conhecimento tão distintos passa a fundir-se e derivar produtos que vêm transformando o dia a dia da sociedade contemporânea. Representa implicações que interferem na vida cotidiana, e estão cada vez mais próximas e a infiltrar-se de modo quase invisível nas vidas humanas. Os resultados das aplicações de Nanotecnologia, benéficos ou não, são questões nas agendas de discussões mundiais e o Brasil não pode furtar-se de inserir-se nelas. 
Figura 6 - Áreas de inserção da Nanotecnologia e aplicações

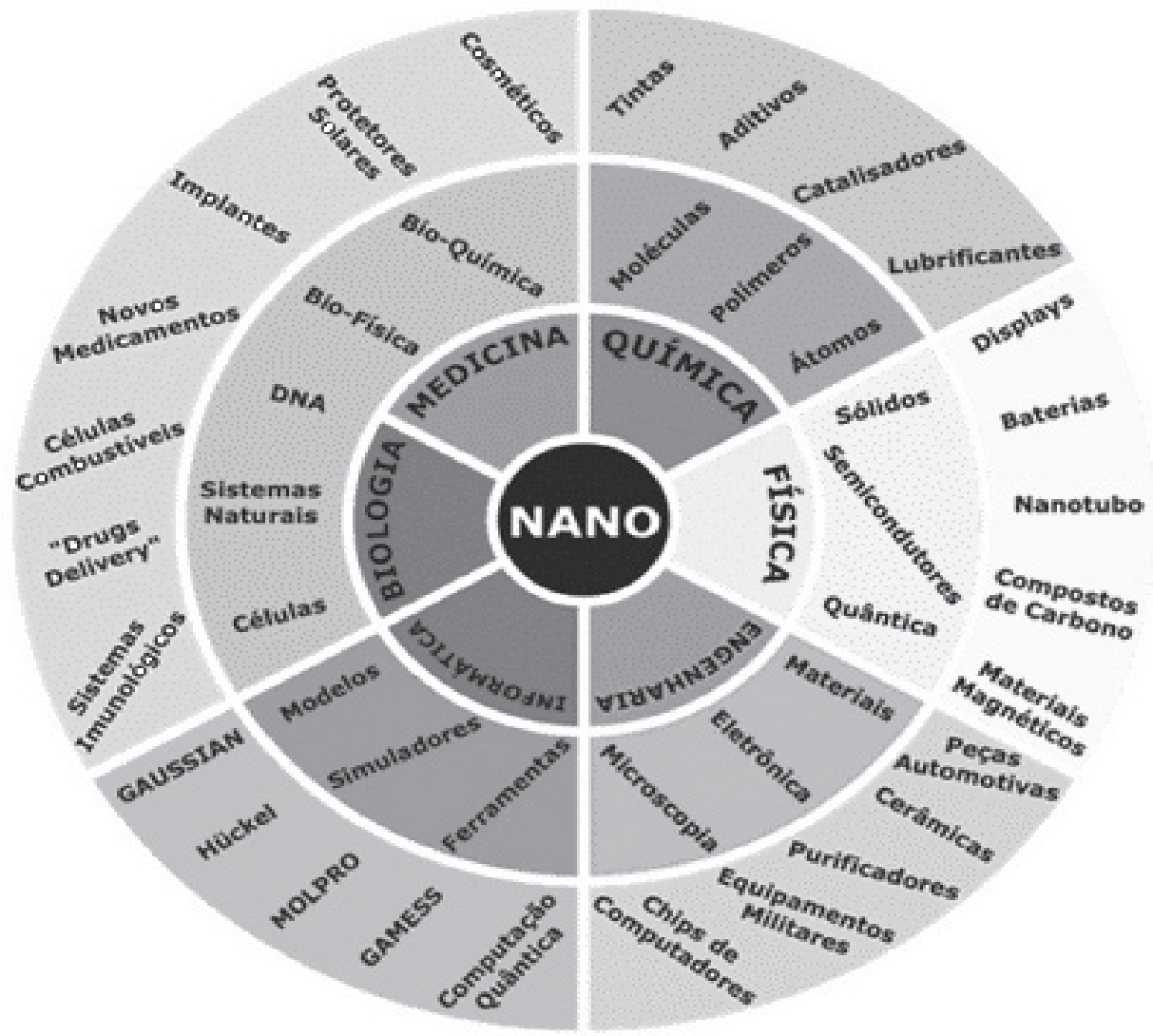

Fonte: Adaptado de Nanotecnologia (2009).

A literatura que cobre a temática está repleta de indicações e detalhes que permitem ampla visibilidade do potencial robusto e detalhado sobre o assunto. No Quadro 5, são pontuadas mais algumas aplicações desta tecnologia tão presente na rotina da sociedade que ainda nem se apercebeu, como deveria, das implicações que ela vem acarretando para sua vida. Uma inserção quase que imperceptível mas consistente e crescente, em segmentos industriais e de serviços, além da medicina, agricultura, segurança entre outros, marcando a revolução que aplicações dessa natureza estão acarretando na sociedade mundial de modo irreverssível. 
Quadro 5 - Aplicações da Nanotecnologia
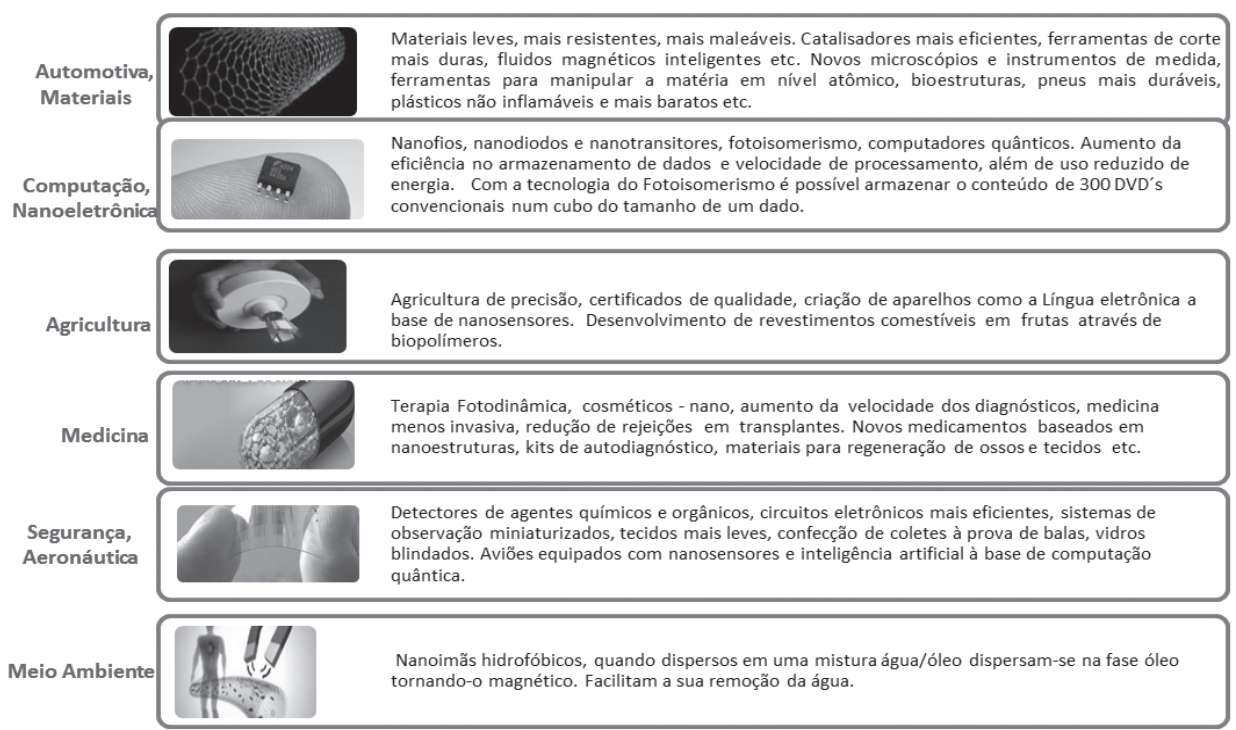

Fonte: Elaboração da autora baseada em Santos Júnior (2011, p. 32).

\section{Mundo das nanoestruturas: conceito, origem e fundamentos da Nanotecnologia}

Nanotecnologia é uma área do conhecimento que causa muita curiosidade e expectativa, especialmente para a parcela da sociedade na qual o tema é pouco difundido. Um mundo desconhecido e cheio de mistérios que pouco a pouco vem sendo desmistificado. É evidente a preocupação em levar para a população uma melhor compreensão.

A etimologia do termo nano, prefixo da palavra nanotecnologia, é atribuída ao grego nanno-, de nános ‘anão', e tem sua origem documentada em vocábulos eruditos, a partir do século XIX (CUNHA, 2011). A este prefixo é creditada a intenção dos cientistas de representarem partículas de magnitude demasiadamente pequenas, os nanômetros (nm), conforme destaca Santos Júnior (2011). Esse autor ainda reitera que o termo "nano também serve como parâmetro de medida, um nanômetro (nm) equivalendo à bilionésima parte de um metro.”

A demonstração da escala nanométrica é apresentada na Figura 7 e ilustra como as nanoestruturas podem ser representadas em dimensões dezenas de 
mil vezes menor do que a do diâmetro de um fio de cabelo, como no exemplo apresentado. Santos Junior (2011, p. 29) acrescenta ainda que "para termos uma noção mais clara, um átomo mede cerca de dois décimos de um nanômetro $(0,2$ nm) e um vírus cerca de 100 nanômetros (100nm)."

Figura 7 - Representação de nanoestruturas em uma escala nanométrica

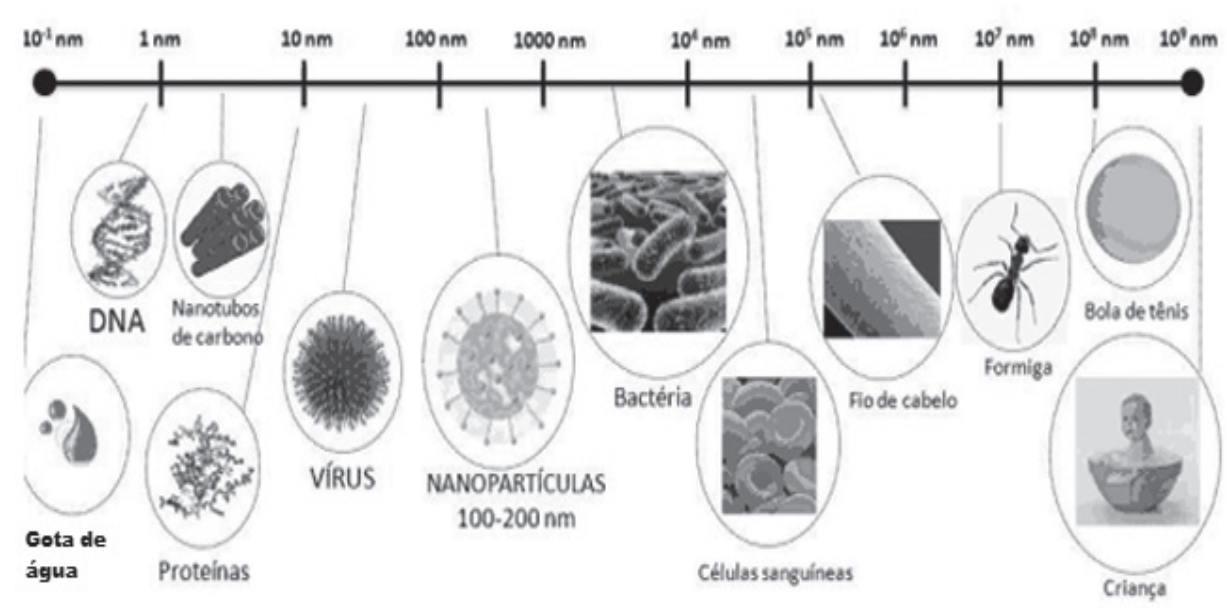

Fonte: Adaptado de TECSAUGEM (2016).

A origem da utilização do termo nanotecnologia possui diversas indicações na literatura científica A palestra proferida por Richard Fernman em 1959, é creditada como marco fundador da área. Ao engenheiro japonês Norio Taniguchi é atribuído à utilização do termo pela primeira vez, em 1974, quando ele o utilizou para designar uma nova tecnologia que ia além do controle de materiais e da engenharia em microescala. Encontam-se também na literatura referências a Eric Drexler como grande disseminador do vocábulo para o grande público, ao atribuir ao termo o significado correspondente à metodologia de processamento que envolve a manipulação átomo a átomo (FERREIRA; RANGEL 2009; SCHULZ, 2013). 
Entretanto, o professor Schultz (2013) conta uma história um pouco diferente $^{3}$ e faz uma incursão a um passado bem mais remoto do que é comumente apresentado nos manuais de introdução à Nanotecnologia, ao referir-se à história da N\&N. Segundo o autor, contar a história da Nanotecnologia sem o devido resgate de suas origens, nada acrescenta a sua compreensão como uma atividade humana de pesquisa e inovação, com importante repercussão social. Contudo, ele ressalva que essa contribuição serve como ponto de partida para a construção de um olhar diferente sobre a temática. A Nanotecnologia é definida conforme Zaneti-Ramos e Creczynski-Pasa (2008, p. 95) como:

[...] a arte de manipular a matéria em nível atômico, construindo moléculas inéditas, com propriedades diferentes. A nanotecnologia encontra aplicações em praticamente todos os setores industriais e de serviços, incluindo as nanopartículas, os revestimentos, catalisadores e nanocomponentes. Muitas destas, já no mercado, revolucionam aplicações de diversos produtos, mudando radicalmente o custo produtivo de muitas indústrias, podendo tornar os produtos não nano alternativas, muitas vezes, não competitivas.

O trabalho realizado de modo incessante por pesquisadores da área contribui de modo satisfatório para atingir resultados que atendem às diversas frentes em que atuam, sejam científicas ou técnicas. No cenário mundial, o despertar para o potencial global da Nanotecnologia criou uma corrida em países, como Estados Unidos e Japão e em conglomerados representados pela União Europeia, em busca do desenvolvimento científico e tecnológico que desse conta da revolução anunciada. Os investimentos em recursos financeiros e humanos para atuar nessa frente de trabalho foram significativos, especialmente da indústria mundial.

São identificadas diversas iniciativas desses países, contudo, os Estados Unidos inicia em 2000, um programa considerado ambicioso pelo montante financeiro empregado. A National Nanotechnology Initiative (NNI) repre-

3 Para maiores detalhes sobre a "história um pouco diferente" consultar o artigo de Schulz (2013). 
senta um programa de pesquisa e desenvolvimento em Nanotecnologia que aumentou as despesas federais em somas altíssimas, um investimento pesado na tecnologia emergente. De modo normativo é assegurada a continuidade do programa pelos anos seguintes de 2005 a 2008 (ZANETI-RAMOS; CRECZYNSKI-PASA, 2008).

O Japão, a China, a Coreia do Sul, Taiwan, Austrália, Canadá, Índia, Malásia, Nova Zelândia, Filipinas, entre outros, são exemplos de países que seguiram os passos dos Estados Unidos e passaram a fazer investimentos governamentais em pesquisas na área de Nanotecnologia. A China também lançou um programa semelhante ao dos Estados Unidos, em 2001, o National Nanotechnology Development Strategy (NNDS), o qual cobria o período de 2001 a 2010. Os estudos desenvolvidos na área realizam-se em um ambiente colaborativo e interdisciplinar, cercado da contribuição global entre países, comunidades profissionais e organizações internacionais (PLENTZ; FAZZIO, 2013; ZANETI-RAMOS; CRECZYNSKI-PASA, 2008).

A movimentação em torno da tecnologia emergente chega ao Brasil. Atualmente, conforme Plentz e Fazzio (2013, p. 23) destacam, "todos os países ditos desenvolvidos e um número grande e crescente de países emergentes e em desenvolvimento têm iniciativas e programas nacionais em $\mathrm{N} \& \mathrm{~N}$, inclusive o Brasil”. As primeiras iniciativas de cunho oficial registradas na área começam no ano de 2000, com reuniões no âmbito do MCT sobre o desenvolvimento futuro da N\&N no país.

Contudo, é importante registrar que em anos anteriores a 2001 havia indícios de pesquisas na área de Nanotecnologia no país, conforme pontua Martins (2007, p. 9) ao afirmar: "sabemos de antemão que já existiam pesquisadores e grupos de pesquisadores trabalhando com nanotecnologia no século passado, bem como diversas teses defendidas sobre o assunto."

A prevalência por formação em redes denota o cunho colaborativo da área e reforça a interdisciplinaridade latente. No Quadro 6, apresenta-se uma breve cronologia dos fatos marcantes para o desenvolvimento da Nanotecnologia no Brasil e destaca-se a ação governamental para o fomento de ações na área. Um desenho dos acontecimentos que evidenciam o crescimento desse domínio do 


\title{
conhecimento no país e o interesse de outros por uma tecnologia considerada estratégica e de vanguarda.
}

\author{
Quadro 6 - Cronologia dos fatos relevantes para a área de Nanotecnologia no \\ Brasil
}

\begin{tabular}{|c|c|}
\hline \multicolumn{2}{|r|}{ FATOS RELEVANTES PARA A ÁREA DE NANOTECNOLOGIA NO BRASIL } \\
\hline 2000 & Reunião seminal do CNPq/MCT sobre o desenvolvimento futuro da N\&N no país. \\
\hline 2001 & $\begin{array}{l}\text { Criadas quatro redes cooperativas de pesquisa na área de Nanotecnologia: Rede de } \\
\text { Nanonotecnologia Molecular e de Interfaces (Renami); Rede de Nanodispositivos, } \\
\text { Semicondutores e Materiais Nanoestruturados (NanoSemiMat); Rede de } \\
\text { Nanobiotecnologia (NanoBioTec); e a Rede de Materiais Nanoestruturados (Nanoest). } \\
\text { Todas essas com fomentos provenientes do CNPq/MCT. Foram também apoiados } \\
\text { quatro Institutos (Virtuais ) do Milênio na área. }\end{array}$ \\
\hline 2002 & $\begin{array}{l}\text { A Capes concede seis bolsas de doutorado para o Laboratório Nacional de Luz } \\
\text { Síncroton (LNLS) em convênio firmado entre a Capes e a Associação Brasileira de Luz } \\
\text { Síncroton (ABTLuS) mantenedora do laboratório. }\end{array}$ \\
\hline 2003 & $\begin{array}{l}\text { Criada a Coordenação-Geral de Políticas e Programas de Nanotecnologia, atualmente } \\
\text { Coordenação de Micro e Nanotecnologias (CGNT). }\end{array}$ \\
\hline 2003 & $\begin{array}{l}\text { Criação do Grupo de Trabalho (GT) pela portaria MCT n 252, de 16.05.2003, } \\
\text { para elaborar a proposta do Programa de Desenvolvimento da Nanociência e } \\
\text { Nanotecnologia. }\end{array}$ \\
\hline 2004 & $\begin{array}{l}\text { Início do Programa de Desenvolvimento da Nanociência e Nanotecnologia no âmbito } \\
\text { do Plano Plurianual (PPA) } 2004 \text { - } 2007 .\end{array}$ \\
\hline 2004 & $\begin{array}{l}\text { Criação do Grupo de Trabalho para estudo sobre a implantação do Laboratório } \\
\text { Nacional de Micro e Nanotecnologia. }\end{array}$ \\
\hline 2004 & Criada a Ação Transversal de Nanotecnologia nos Fundos Setoriais. \\
\hline 2004 & $\begin{array}{l}\text { Instituída a Rede BrasilNano e seu Comitê Gestor pela portaria n } 614 \text {, de } 1^{\circ} \text { de } \\
\text { dezembro de 2004, composta por dez redes de pesquisa em Nanotecnologia: Rede } \\
\text { de Nanofotônica; Rede Nacional de NanoBiotecnologia e Sistemas Nanoestruturados } \\
\text { (NanoBioEstruturas); Rede de Nanotecnologia Molecular e de Interfaces - Estagio } \\
\text { III; Nanotubos de Carbono: ciência e Aplicações; Nanocosméticos: do Conceito } \\
\text { às Aplicações Tecnológicas; Microscopia de Varredura de Sondas - Software e } \\
\text { Hardware Abertos; Simulação e Modelagem de nanoestruturas; Rede Cooperativa } \\
\text { de Pesquisa em Revestimentos Nanoestruturados; Nanoglicobiotecnologia; Rede de } \\
\text { Nanobiomagnetiso. }\end{array}$ \\
\hline 2005 & Designados os membros do Conselho Diretor da Rede BrasilNano. \\
\hline 2005 & Lançado o Programa Nacional de Nanotecnologia (PNN). \\
\hline 2005 & $\begin{array}{l}\text { Assinado o Protocolo de Intenções entre Brasil e Argentina criando o Centro } \\
\text { Brasileiro-Argentino de Nanotecnologia (CBAN). }\end{array}$ \\
\hline 2005 & $\begin{array}{l}\text { Selecionadas dez Redes Nacionais de Nanotecnologia, com atuação prevista para o } \\
\text { período 2006-2009. }\end{array}$ \\
\hline 2006 & Início de atividades do CBAN. \\
\hline 2007 & $\begin{array}{l}\text { Lançamento do Plano de Ação em C\&T\&I - PACTI, cujas ações são executadas de } \\
\text { forma articulada e coordenada por diversos Ministérios, tendo à frente o MCT. }\end{array}$ \\
\hline
\end{tabular}




\begin{tabular}{|c|c|}
\hline 2008 & $\begin{array}{l}\text { Inauguração do Centro de Nanociência e Nanotecnologia Cesar Lattes, construído no } \\
\text { campus do LNLS, em março de } 2008 .\end{array}$ \\
\hline 2008 & $\begin{array}{l}\text { Lançamento pelo Governo Federal da Política de Desenvolvimento Produtivo (PDP) } \\
\text { em maio de 2008. Integra a PDP o Programa Mobilizador em Nanotecnologia, cuja } \\
\text { gestão está a cargo do MCT. }\end{array}$ \\
\hline 2008 & $\begin{array}{l}\text { Lançada chamada para o Programa INCTs que contempla as oito áreas estratégicas do } \\
\text { PACTI 2007-2010, dentre elas a de Nanotecnologia. }\end{array}$ \\
\hline $\begin{array}{l}2008 / \\
2009\end{array}$ & $\begin{array}{l}\text { Esforço conjunto entre } \mathrm{MCT}, \mathrm{MDCl} \text { e a Associação Brasileira de Desenvolvimento } \\
\text { Industrial (ABDI) para divulgação da Nanotecnologia no setor privado, ressaltando } \\
\text { sua relevância estratégica como ferramenta para inovação. }\end{array}$ \\
\hline 2009 & $\begin{array}{l}\text { Lançamento do Fórum de Competitividade de Nanotecnologia como ferramenta } \\
\text { estratégica de apoio às iniciativas e programas segundo as dimensões da PDP. } \\
\text { Criação de quatro GTs. }\end{array}$ \\
\hline 2010 & Apoio a 17 novas redes cooperativas através do edital MCT/CNPq n 74/2010. \\
\hline 2011 & $\begin{array}{l}\text { Aberta uma chamada pública MCTI/CNPq n 17/2011. Apoio à criação de } \\
\text { redes cooperativas de pesquisa e desenvolvimento em nanotoxicologia e } \\
\text { nanoinstrumentação. }\end{array}$ \\
\hline 2012 & $\begin{array}{l}\text { Lançamento do Edital MCTI/CNPq } n^{\circ} 16 / 2012 \text { pela CGNT em conjunto com o CNPq, } \\
\text { para apoiar tecnologias inovadoras e/ou aumento da produção, prototipagem de } \\
\text { escala em nanotecnologia e que apoio } 25 \text { projetos com investimento total de pouco } \\
\text { mais de R\$ } 6 \text { milhões. }\end{array}$ \\
\hline 2013 & $\begin{array}{l}\text { Ação do MEC e da Capes em acordo de cooperação entre Portugal e Espanha na área } \\
\text { de Nanotecnologia }\end{array}$ \\
\hline 2014 & $\begin{array}{l}\text { Lançamento da Chamada INCT-MCTI/CNPq/Capes/FAPs nº } 16 \text { de 2014, em } \\
\text { continuidade ao Programa INCTs. }\end{array}$ \\
\hline 2016 & $\begin{array}{l}\text { Resultado da Chamada INCT-MCTI/CNPq/Capes/FAPs n }{ }^{\circ} 16 \text { de 2014, divulgado no } \\
\text { dia } 11 \text { de maio de } 2016, \text { com } 230 \text { INCTs pré-aprovados. }\end{array}$ \\
\hline
\end{tabular}

Fonte: Elaboração as autora baseada em dados de pesquisa e informações do CNPq (2016b), Plentz e Fazio (2013).

Após a sinalização de algumas medidas adotadas no âmbito governamental, ficou evidente os esforços despendidos pelo governo em iniciativas que buscavam o desenvolvimento e fortalecimento da Nanotecnologia no país. A pesquisa desenvolvida analisou a $e$-Science e as práticas colaborativas voltadas à inovação e a ela associadas, no âmbito dos INCTs da área de Nanotecnologia. Justificou-se desse modo, a incursão realizada pela pesquisadora, no âmbito das iniciativas para desenvolvimento da $\mathrm{N} \& \mathrm{~N}$, um esforço no sentido de entendimento e apropriação das questões peculiares ao fomento de pesquisas na área. 


\section{INSTITUTOS NACIONAIS DE CIÊNCIA E TECNOLOGIA DE NANOTECNOLOGIA}

Identificar os INCTs da área de Nanotecnologia e os pesquisadores que neles atuam é uma contribuição para a área e um trabalho de sistematização de informações dispersas em várias fontes de informação. A escolha desses institutos como locus de análise foi pautada nos seguintes elementos: estrutura de funcionamento dos institutos em redes colaborativas; indiscutível utilização de tecnologia de ponta na área; alto nível de pesquisas desenvolvidas pelos pesquisadores do quadro; representatividade dos institutos como resultado de uma política pública, cuja atuação vinculava-se à disponibilidade de verbas do governo para seu funcionamento e manutenção; caráter interdisciplinar da área com expressivo índice colaborativo.

Além das razões pontuadas, levou-se em consideração a importância que os institutos da área de Nanotecnologia representavam para o cenário mundial e desenvolvimento da sociedade. Somou-se também a crença de que o modelo de funcionamento dos institutos era parecido com o de órgãos estrangeiros voltados para o desenvolvimento de pesquisas e apoio a iniciativas no âmbito da e-Science.

As atividades realizadas pelos pesquisadores desses institutos culminaram em insumos resultantes de um fazer científico traduzido, entre outras demandas, como práticas colaborativas as quais tinham como alicerce a utilização de tecnologia de ponta. Esses estavam inseridos nos INCTs que representavam uma das oito áreas estratégicas contempladas pelo PACTI 2007-2010 para o desenvol- 
vimento da CT\&I nacional e foram identificados e caracterizados nas subseções seguintes.

\section{Identificação dos INCTS e informantes}

O levantamento preliminar realizado nos sítios individuais dos INCTs, sítios oficiais do CNPq e Portal Brasileiro de Ciência e Tecnologia, atendeu ao primeiro objetivo específico da pesquisa desenvolvida que derivou esse livro - Levantar os INCTs contemplados no Programa Institutos Nacionais de Ciência e Tecnologia, lançado em 2008, e os pesquisadores atuantes no quadro. O resultado obtido permitiu o diagnóstico preliminar desses INCTs e do quantitativo de pesquisadores que nesses atuavam, o primeiro movimento no sentido de rastrear as pistas deixadas no processo de formação e desmantelamento dos grupos que compunham os institutos investigados é apresentado no Quadro 7.

Quadro 7 - INCTs da área de Nanotecnologia

\begin{tabular}{|c|c|c|c|c|c|}
\hline N. & INCT & Sigla & Coordenador $(A)$ & Sede & $\begin{array}{c}\mathrm{N}^{\circ} \mathrm{De} \\
\text { Pesquisadores }\end{array}$ \\
\hline 1 & $\begin{array}{l}\text { Instituto Nacional de } \\
\text { Ciência e Tecnologia } \\
\text { de Catálise em } \\
\text { Sistemas Moleculares e } \\
\text { Nanoestruturados }\end{array}$ & CATÁLISE & $\begin{array}{l}\text { Faruk José Nome } \\
\text { Aguilera }\end{array}$ & UFSC & 60 \\
\hline 2 & $\begin{array}{l}\text { Instituto Nacional de } \\
\text { Ciência e Tecnologia em } \\
\text { Materiais Complexos } \\
\text { Funcionais }\end{array}$ & INOMAT & $\begin{array}{l}\text { Fernando } \\
\text { Galembeck }\end{array}$ & Uniamp & 138 \\
\hline 3 & $\begin{array}{l}\text { Instituto Nacional de } \\
\text { Ciência e Tecnologia de } \\
\text { Ciência dos Materiais } \\
\text { em Nanotecnologia }\end{array}$ & INCTMN & $\begin{array}{c}\text { Elson Longo da } \\
\text { Silva }\end{array}$ & Unesp & 74 \\
\hline 4 & $\begin{array}{l}\text { Instituto Nacional de } \\
\text { Ciência e Tecnologia } \\
\text { de NanoBioEstruturas } \\
\text { e Simulação } \\
\text { NanoBioMolecular }\end{array}$ & NANOBIOSIMES & $\begin{array}{l}\text { Benildo Sousa } \\
\text { Cavada }\end{array}$ & UFC & 52 \\
\hline 5 & $\begin{array}{l}\text { Instituto Nacional de } \\
\text { Ciência e Tecnologia de } \\
\text { NanoBioFarmacêutica }\end{array}$ & NANOBIOFAR & $\begin{array}{l}\text { Robson Augusto } \\
\text { Souza dos Santos }\end{array}$ & UFMG & 88 \\
\hline 6 & $\begin{array}{l}\text { Instituto Nacional de } \\
\text { Ciência e Tecnologia de } \\
\text { Nanotecnologia para } \\
\text { Marcadores Integrados }\end{array}$ & INAMI & $\begin{array}{l}\text { Oscar Manoel } \\
\text { Loureiro Malta }\end{array}$ & UFPE & 88 \\
\hline
\end{tabular}




\begin{tabular}{|c|c|c|c|c|c|}
\hline 7 & $\begin{array}{l}\text { Instituto Nacional de } \\
\text { Ciência e Tecnologia } \\
\text { de Nanomateriais de } \\
\text { Carbono }\end{array}$ & NANOCARBONO & $\begin{array}{c}\text { Marcos Assunção } \\
\text { Pimenta }\end{array}$ & UFMG & 73 \\
\hline 8 & $\begin{array}{l}\text { Instituto Nacional de } \\
\text { Ciência e Tecnologia } \\
\text { de Sistemas Micro e } \\
\text { Nanoeletrônicos }\end{array}$ & NAMITEC & $\begin{array}{c}\text { Jacobus } \\
\text { Willibrordus Swart }\end{array}$ & $\begin{array}{c}\text { CTI/ } \\
\text { Unicamp }\end{array}$ & 162 \\
\hline 9 & $\begin{array}{l}\text { Instituto Nacional de } \\
\text { Ciência e Tecnologia de } \\
\text { Nanobiotecnologia do } \\
\text { Centro-Oeste e Norte }\end{array}$ & NANOBIOTECNOLOGIA & $\begin{array}{c}\text { Ricardo Bentes de } \\
\text { Azevedo }\end{array}$ & UnB & 65 \\
\hline 10 & $\begin{array}{l}\text { Instituto Nacional de } \\
\text { Ciência e Tecnologia } \\
\text { de Nanodispositivos } \\
\text { Semicondutores }\end{array}$ & DISSE & $\begin{array}{c}\text { Patrícia Lustoza de } \\
\text { Souza }\end{array}$ & PUC-RJ & 55 \\
\hline TOTAL & & & & & 855 \\
\hline
\end{tabular}

Fonte: Elaborado pela autora.

O resultado apresentado na sequência compreendeu a identificação dos INCTs da área de Nanotecnologia e os pesquisadores do quadro. A localização das sedes dos INCTs e o local de atuação dos pesquisadores foram dos primeiros dados contemplados. Essa informação que possibilitou uma percepção da distribuição espacial coberta pelos institutos e a justificativa pela atuação que eles implementram nas mais diversas frentes no país.

As sedes dos INCTs estavam presentes em quatro regiões do país, conforme pode se constatar na Figura 8. Entretanto, a região norte, apesar de não abrigar nenhuma sede de INCT, constituía no NANOBIOTECNOLOGIA um forte referencial, por seu espectro de atuação abarcar as regiões Centro-Oeste e Norte. Esse instituto ainda vinculava-se a sete instituições da região Norte, a saber: UFRN, UFPA, UFAC, UNIR, CT-PIM, UFAM e Unifap.

A região Sudeste agregou o maior número de institutos, seis, a seguir discriminados: NAMITEC, DISSE, NANOCARBONO, INOMAT, INCTMN e NANOBIOFAR. A região Nordeste agregou mais dois, o INAMI e o NANOBIOSIMES. As regiões Centro-Oeste e Sul apenas um instituto cada, o NANOBIOTECNOLOGIA e o CATÁLISE respectivamente.

As instituições que possuíam ligação com INCTs da área de Nanotecnologia estavam distribuídas nas cinco regiões do país. A prevalência da região Sudeste é destacada por agregar 44\% das instituições, seguida pelas regiões Sul (20\%) 
e Nordeste (19\%). As regiões Norte e Centro-Oeste agregaram respectivamente $9 \%$ e $8 \%$ das instituições vinculadas.

Figura 8 - Localização da sede dos INCTs de Nanotecnologia nas regiões do Brasil.

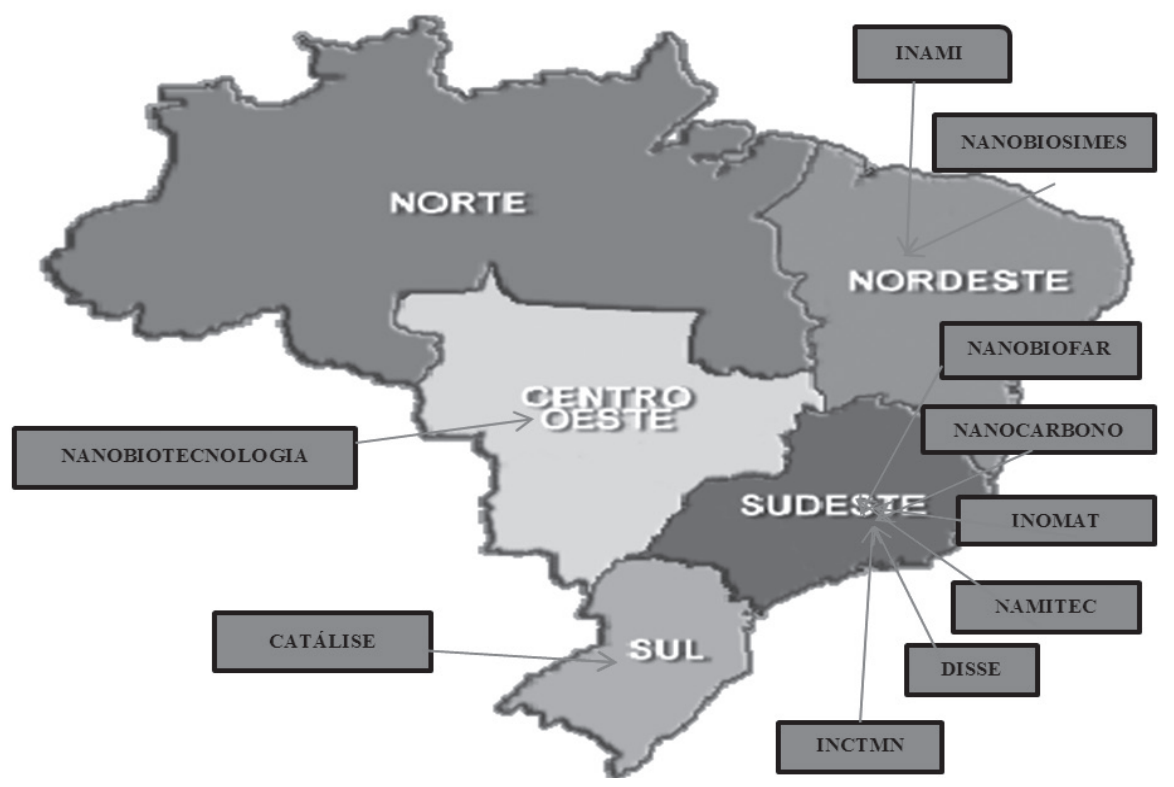

Fonte: Elaboração da autora.

A região Sudeste também agregou o maior percentual de pesquisadores em atuação nos INCTs, (65\%.) O grande número de INCTs com sede nessa região, e a firme atuação da FAPESP, agência de fomento local, justificaram o percentual obtido.

As outras regiões obtiveram percentuais mais modestos relacionados à presença de pesquisadores, mas nem por isso menos representativos: região Nordeste (20\%); região Centro-Oeste (8\%); região Sul (6\%); e região Norte (1\%) apenas. Apesar de na região Norte existir um número crescente de instituições vinculadas aos INCTs, o percentual de pesquisadores atuantes na região ainda é pequeno, apenas $1 \%$ do total obtido nas outras regiões do país. O Gráfico 1, ilustrou os resultados obtidos. 
Gráfico 1 - Pesquisadores associados - Localização do INCT

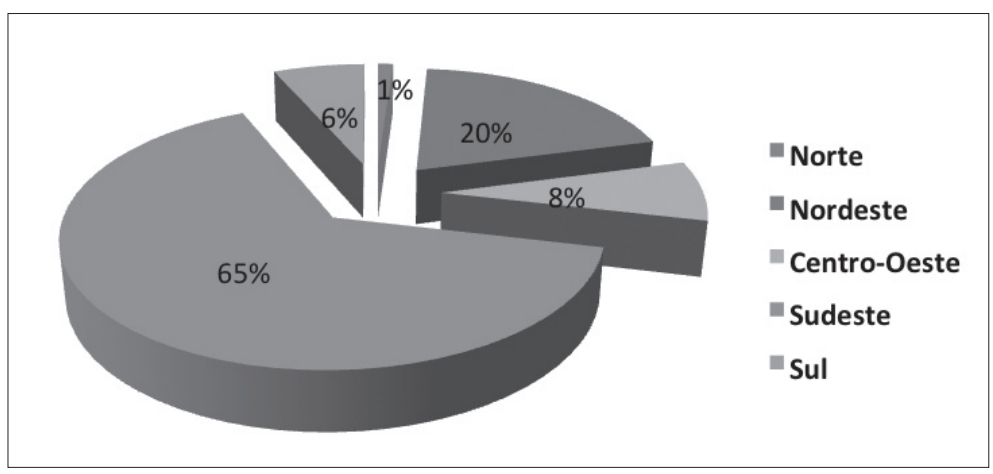

Fonte: Dados da pesquisa.

\section{Perfil dos pesquisadores}

O "passeio" pelos INCTs iniciou-se pela trajetória acadêmica dos 855 pesquisadores identificados, a qual contemplou na análise apenas os cursos de graduação e doutorado na análise. Entretanto, o mestrado, estágio pós-doutoral e livre docência foram computados quantitativamente. A caracterização dos pesquisadores realizou-se com o objetivo da aquisição de conhecimentos pertinentes ao corpus estudado. As informações obtidas facilitaram o trânsito e ambientação em uma área, a princípio desconhecida, mas que surpreendeu com seu potencial atrativo e relevância estratégica para a sociedade.

O curso de química foi o mais indicado, no cômputo geral, com 235 ocorrências e figurou em três INCTs como o mais cotado: no CATÁLISE, no INOMAT e no INAMI. O curso de física foi o segundo colocado, com 212 ocorrências; entretanto, em termos de representatividade foi a primeira indicação em quatro institutos: no INCTMN, o NANOBIOSIMES, no NANOCARBONO e no DISSE. A distribuição dos cursos nos institutos estava em consonância com as habilidades e qualificações exigidas para as atividades que eram desempenhadas pelos pesquisadores nos INCTs que caracterizavam a área de Nanotecnologia. Tais atividades correspondiam à expertise necessária para o bem fazer científico e adequavam-se de modo satisfatório a atribuição esperada para cada INCT.

Adotou-se uma classificação que identificou as áreas de conhecimento nas quais os cursos estavam inseridos, a qual reuniu os cursos correlatos e agregou 
indicações dispersas devido à nomenclatura utilizada pelos pesquisadores. Adotou-se como parâmetro a Tabela de Áreas do Conhecimento da Capes (CAPES, 2012) e sua utilização deveu-se apenas à facilidade didática que permitiu enquadrar os diversos cursos indicados pelos pesquisadores. O enquadramento não entra no mérito das questões políticas nem específicas das áreas representadas nas subdivisões encontradas. O Gráfico 2, destacou as áreas do conhecimento contempladas nos cursos de graduação desses pesquisadores.

Gráfico 2 - Áreas do conhecimento - Graduação

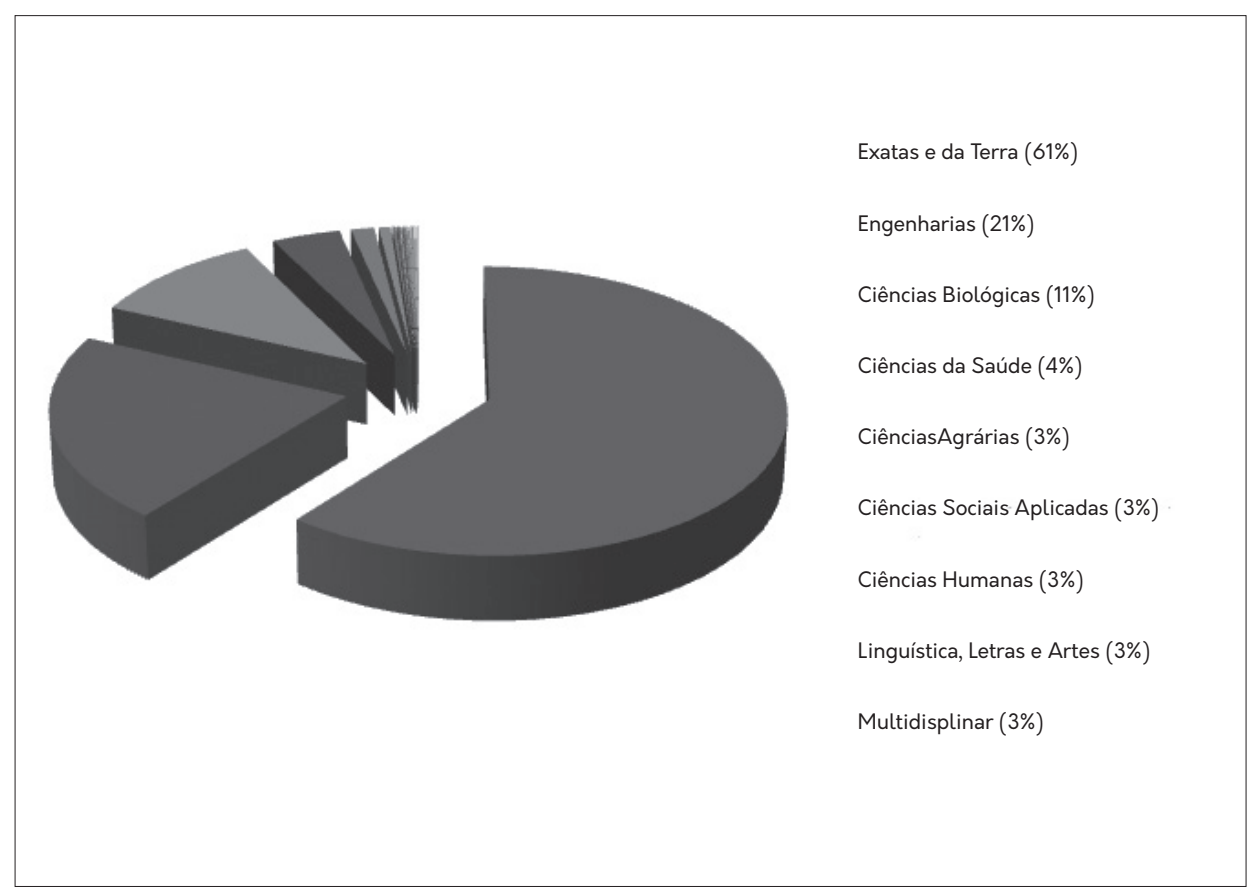

Fonte: Elaboração da autora.

A primeira evidência observada foi a predominância do campo das ciências exatas e da terra na formação dos pesquisadores. A representatividade deste campo do conhecimento correspondeu ao total de 519 pesquisadores, 61\% no cômputo geral. Observou-se forte presença das ciências naturais, as quais ainda contemplaram ainda as engenharias, com 181 pesquisadores (21\%) e as ciências biológicas com 91 sujeitos (11\%). As ciências da saúde também foram represen- 
tadas, com 35 (4\%). Havia também atuando nos INCTs pesquisadores das áreas das ciências agrárias, humanas, sociais aplicadas, linguística, letras e artes e multidisciplinar, apesar em pequeno número: essas representaram $3 \%$ do total de indicações. No grupo, encontraram-se ainda alguns pesquisadores que possuíam duas graduações, mas que seguiam o padrão predominante: uma dessas estava relacionada a cursos cobertos pelo campo das ciências naturais. Esse conjunto foi representado por oito pesquisadores, $0,9 \%$ do total das indicações. Apesar do predomínio de pesquisadores com formação na área das ciências exatas e da terra, confirmou-se a presença de múltiplas áreas do conhecimento nos INCTs identificados, a caracterizar forte traço no perfil da área de Nanotecnologia. Os pesquisadores com suas distintas formações, representaram o amplo universo das áreas de conhecimento que contempla a diversidade que enriquece a área da Nanotecnologia.

O curso de doutorado mais indicado foi na mesma área do curso da graduação. Os cursos da área de Química, no âmbito dos INCTs da área de Nanotecnologia, podem ser considerados como "carros-chefe" em termos de ocorrência por perfazerem o total de 222 indicações no geral. Observou-se, contudo, que a área foi citada várias vezes, seja de modo particularizado por sua especialidade ou paralelamente a outros cursos. Se o total de ocorrências da palavra fosse computado seu valor seria bem maior que o apresentado.

A reestruturação do grupo em INCTs da área de Nanotecnologia permitiu a agregação de 855 pesquisadores altamente qualificados em sua maioria. Apesar de uma parcela destes pesquisadores possuírem um histórico de atuação em redes colaborativas na área essas vinham sendo consolidadas à medida que que se realizavam novos aportes e iniciativas por parte do governo. A nova formação em INCTs fortaleceu o núcleo existente e permitiu o desenvolvimento de novos projetos.

O Gráfico 3 salientou a prevalência dos INCTs na área das ciências exatas e da terra com 66\% das indicações. Seguiram-se as engenharias (14\%), as ciências biológicas (13\%), as ciências da saúde (3\%), e a multidisciplinar (2\%). As ciências agrárias, sociais aplicadas e humanas mantiveram sua representatividade, embora com um número bem pequeno de pesquisadores, como nos cursos da graduação. Essas somaram 19 sujeitos, os quais correspondiam juntos a 4\% do total das indicações 
Gráfico 3 - Áreas do conhecimento - Doutorado

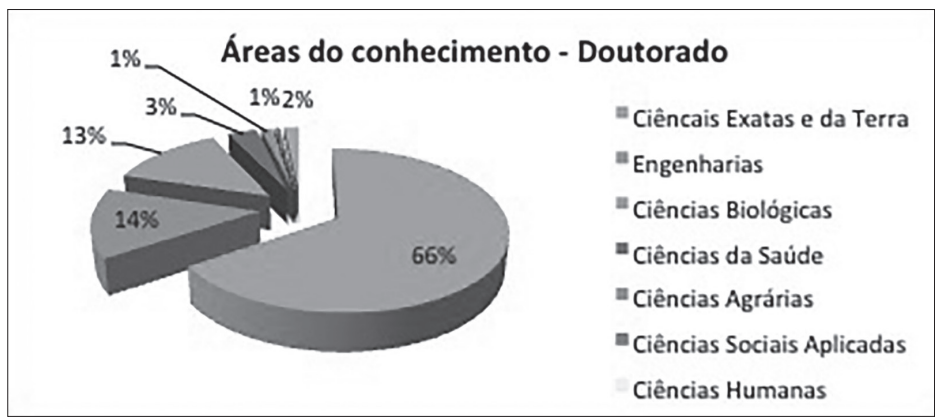

Fonte: Elaboração da autora.

A alta titulação acadêmica dos pesquisadores reforçou a assertiva que os qualificava como membros de uma elite científica, com representantes dos melhores grupos de sua área de atuação e com relevante qualificação. Atende-se, desse modo, a um dos requisitos do Programa INCTs pontuado no Edital 15/2008 MCT (CNPq, 2008), quando se refere à qualificação dos pesquisadores que deveriam atuar nos INCTs selecionados.

A Tabela 2, comprovou esta informação e destacou as 530 ocorrências de pesquisadores que realizaram o estágio pós-doutoral, um percentual de $62 \%$ do total. O número de doutores também foi representativo foram: 244 pesquisadores com doutorado (29\%).

Tabela 2 - Titulação acadêmica - Pesquisadores dos INCTs de Nanotecnologia

\begin{tabular}{|c|c|c|c|c|c|c|c|c|c|}
\hline \multirow[b]{2}{*}{$\mathrm{N}$} & \multirow[b]{2}{*}{ INCT } & \multicolumn{8}{|c|}{ TITULAÇÃO } \\
\hline & & Graduação & Especialização & Mestrado & Doutorado & $\begin{array}{c}\text { Pós- } \\
\text { Doutorado }\end{array}$ & $\begin{array}{c}\text { Livre } \\
\text { Docência }\end{array}$ & $\begin{array}{l}\text { Livre } \\
\text { Docência } \\
\text { e Pós- } \\
\text { Doutorado }\end{array}$ & TOTAL \\
\hline 1 & CATÁLISE & & & & 10 & 49 & 1 & & 60 \\
\hline 2 & INOMAT & 1 & & 8 & 31 & 86 & 1 & 11 & 138 \\
\hline 3 & INCTMN & & & 1 & 13 & 49 & 4 & 7 & 74 \\
\hline 4 & NANOBIOSIMES & & & & 17 & 35 & & & 52 \\
\hline 5 & NANOBIOFAR & & & & 27 & 60 & & 1 & 88 \\
\hline 6 & INAMI & 1 & & & 30 & 53 & 4 & & 88 \\
\hline 7 & DISSE & & & 11 & 16 & 27 & & 1 & 55 \\
\hline
\end{tabular}




\begin{tabular}{|c|c|c|c|c|c|c|c|c|c|}
\hline \multirow[b]{2}{*}{$\mathrm{N}$} & \multirow[b]{2}{*}{ INCT } & \multicolumn{8}{|c|}{ TITULAÇÃO } \\
\hline & & Graduação & Especialização & Mestrado & Doutorado & $\begin{array}{c}\text { Pós- } \\
\text { Doutorado }\end{array}$ & $\begin{array}{c}\text { Livre } \\
\text { Docência }\end{array}$ & $\begin{array}{c}\text { Livre } \\
\text { Docência } \\
\text { e Pós- } \\
\text { Doutorado }\end{array}$ & TOTAL \\
\hline 9 & NAMITEC & & & 9 & 69 & 75 & 4 & 5 & 162 \\
\hline 10 & NANOCARBONO & 1 & & 1 & 12 & 56 & 3 & & 73 \\
\hline & TOTAL & 3 & 1 & 33 & 244 & 530 & 17 & 27 & 855 \\
\hline
\end{tabular}

Fonte: Elaboração da autora.

Os Gráficos 4 e 5, permitiram a comparação dos resultados dos dois instrumentos de coleta utilizados. A comprovação das informações que foram coletadas em distintos instrumentos validou os dados obtidos e ofereceu a confiabilidade necessária para a análise que foi realizada sobre o indicador de titulação. Olhares distintos, os quais reforçaram a assertiva que qualificou os pesquisadores dos INCTs da área de Nanotecnologia como um grupo de excelência.

Gráfico 4 - Titulação - Levantamento inicial

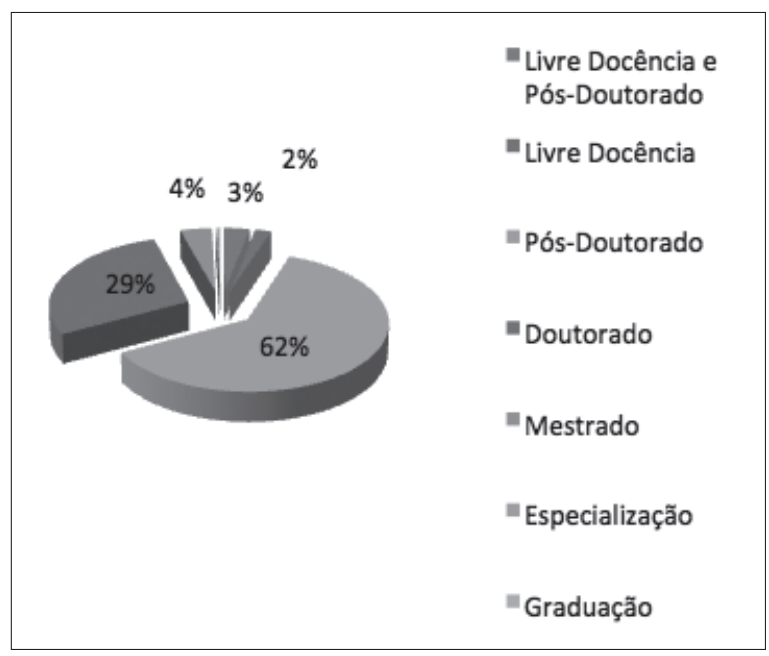

Fonte: Elaboração da autora 
Gráfico 5 - Titulação - Questionário online

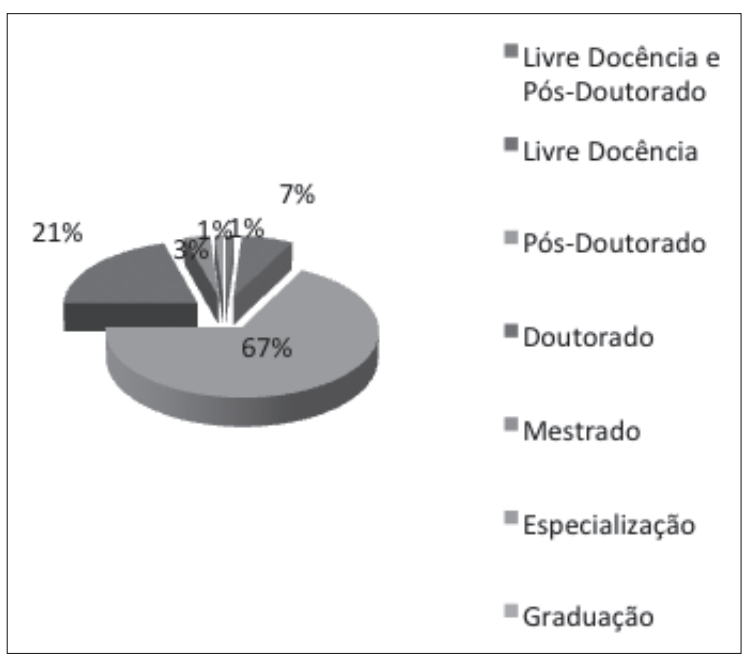

Fonte: Elaboração da autora.

Ao comparar-se os dois resultados ficaram evidentes as semelhanças e paridade nos quantitativos de dados e métodos distintos. A alta titulação representada pelo estágio pós-doutoral foi novamente destacada com $62 \%$ no levantamento inicial e $67 \%$ no questionário online, caracterizada a ampla maioria entre as titulações sinalizadas nos dois métodos utilizados.

A varíavel gênero na caracterização dos pesquisadores dos dez INCTs identificados na área de Nanotecnologia, indicados nos Gráficos 6 e 7 foram apresentados lado a lado e correspondem aos resultados obtidos no levantamento inicial e no questionário online respectivamente da pesquisa de derivou esse livro. O número significativo de representantes do gênero masculino foi registrado em ambos: $73 \%$ no primeiro e $78 \%$ no segundo. Com relação às representantes do gênero feminino, $27 \%$ no primeiro gráfico e $22 \%$ no segundo. 
Gráfico 6 - Gênero - Levantamento inicial

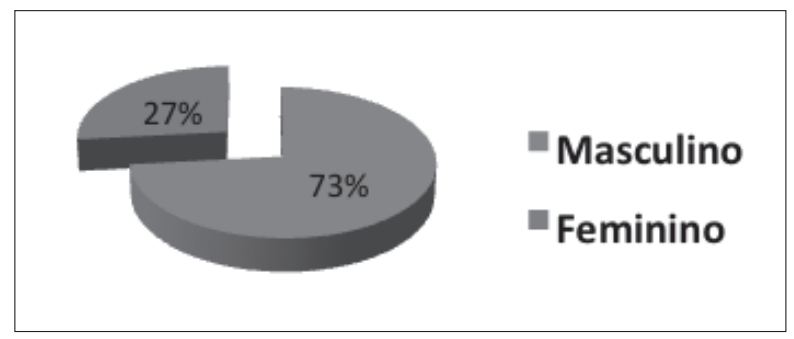

Fonte: Elaboração da autora.

\section{Gráfico 7- Gênero- Questionário online}

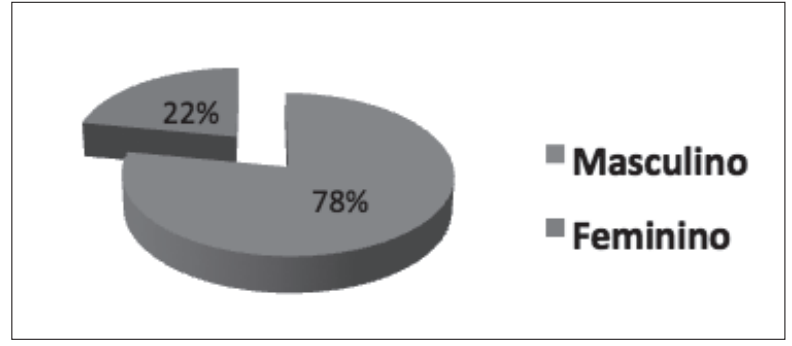

Fonte: Elaboração da autora.

A análise dessa variável não foi realizada em profundidade e sua utilização prende-se apenas à demonstração quantitativa entre os INCTs da área de Nanotecnologia. Identificou-se contudo, durante o levantamento da literatura pertinente a área, um estudo realizado por Rigolin e colaboradores (2013), no qual analisam a categoria gênero nos INCTs coordenados por mulheres, uma opção para aprofundamento sobre a temática.

A faixa etária dos pesquisadores dos INCTs da área de Nanotecnologia foi uma variável obtida com os dados do questionário online aplicado. Como o levantamento inicial foi realizado em sítios que não contemplavam este dado, não foi possível obter essa informação desse instrumento de coleta. A faixa etária com o maior percentual de respondentes foi a dos 40 a 49 anos, com 33 sujeitos (36\%). Em seguida, a dos 50 a 59, com 26 pesquisadores (29\%) e a dos 30 a 39, com 22 respondentes (24\%). Do total de respondentes, apenas 10 pesquisadores 
(11\%) na faixa dos 60 anos. O Gráfico 8 logo abaixo apresentado, ilustra esta informação.

Gráfico 8 - Faixa etária dos pesquisadores dos INCTs de Nanotecnologia

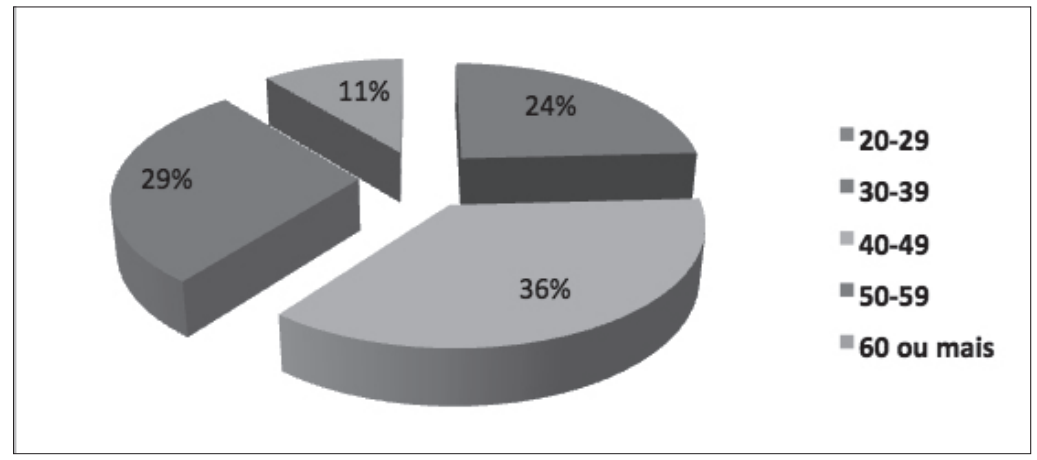

Fonte: Elaboração da autora.

Infere-se, com estas informações, que os pesquisadores dos INCTs da área de Nanotecnologia formavam uma população de pesquisadores adultos experientes, levando-se em conta os $65 \%$ que corresponderam às faixas etárias em torno dos 40-49/50-59. Essas faixas representam um período no qual boa parte da trajetória acadêmica pode ter sido pecorrida, necessária para a formação de um pesquisador qualificado. Esse percentual justificou também a alta titulação, pontuada nos parágrafos anteriores, porque a idade pode ser considerada como um ponto favorável para a trajetória cientifica-acadêmica. A faixa etária entre os 20-29 não foi indicada por nenhum respondente.

\section{Natureza do grupo}

Os pesquisadores associados aos INCTs da área de Nanotecnologia já desenvolviam atividades científicas alinhadas com os anseios do Programa INCTs, e ao terem suas propostas contempladas, somaram mais um elemento, o qual facilitou o trabalho desenvolvido a partir deste momento. Esses pesquisadores obtiveram as condições necessárias para dar continuidade à sua prática científico-tecnológica e ainda contribuir para o avanço da Ciência, Tecnologia e Ino- 
vação nacional em um domínio considerado emergente, como a área de Nanotecnologia.

Em continuidade às recomendações da ANT para caracterizar a natureza do grupo destacaram-se as atividades desenvolvidas de um modo geral nos INCTs e a contribuição que eles ofereciam para a sociedade. Caracterizar um domínio de estudo utilizado para a análise da e-Science, como modelo brasileiro para o suporte e manutenção de uma infraestrutura de pesquisa colaborativa, foi fundamental para o bom desenvolvimento do trabalho. Seguiram-se, desse modo, as recomendações da ANT quando se buscou a identificação da primeira fonte de incerteza no sentido de caracterizar a natureza do grupo.

Apresentou-se no Quadro 8, novo retrato dos INCTs identificados no levantamento inicial, acrescido das instituições vinculadas, o qual indicou a ordem em que os institutos foram pontuados e a sequência das informações a eles pertinentes ao longo da seção. Resgatou-se ainda a indicação da sede e o total de pesquisadores contemplados.

Quadro 8 - INCTs de Nanotecnologia e vínculos

\begin{tabular}{|c|c|c|c|c|}
\hline \multicolumn{5}{|c|}{ INCTs DE NANOTECNOLOGIA E VÍNCULOS } \\
\hline INCT & Sede & $\begin{array}{c}\mathrm{N}^{\mathrm{a}} \text { de } \\
\text { Pesquisadores }\end{array}$ & Instituições vinculadas & \\
\hline CATÁLISE & UFSC & 60 & $\begin{array}{l}\text { UFSC, USP, Unicamp, UnB, UFSM, } \\
\text { UFSCar, UFRGS, UFPel, UFMG, UFPB, } \\
\text { UFAL, UENF, PUCRS,FURB }\end{array}$ & 14 \\
\hline INOMAT & Unicamp & 138 & $\begin{array}{l}\text { Unicamp, USP, UFRJ, UFBA, UEM, UFC, } \\
\text { LNNano/CNPEM }\end{array}$ & 7 \\
\hline INCTMN & Unesp & 74 & $\begin{array}{l}\text { Unesp, UFSCar, USP, IPEN, Unifesp, } \\
\text { UFABC, UFRN, UFPB, UnB, CBPF, UFPI, } \\
\text { IFMA, UFG, UEG, UFMS, UEPG }\end{array}$ & 16 \\
\hline NANOBIOSIMES & UFC & 52 & $\begin{array}{l}\text { UFC, UFRN, UFAL, UFSM, UFPA, UFMA, } \\
\text { UVA, UECE, UFPB, IFCE, IFM, Urca, Unifra }\end{array}$ & 13 \\
\hline NANOBIOFAR & UFMG & 88 & $\begin{array}{l}\text { Bioss, EPFL, HSL, IC-FUC, Incor, MIT, MDC, } \\
\text { UC, PUC-MG, UFBA, UFAL, UFG, Unifei, } \\
\text { UFJF, UFLA, UFMG, UFOP, UFSJ, UFU, UB, } \\
\text { UA, GLA, SDU, USC, UFL, Medunigraz }\end{array}$ & 26 \\
\hline INAMI & UFPE & 88 & $\begin{array}{l}\text { UFPE, UFOP, UEPB, UFCG, UFPB, UFAL, } \\
\text { USP, UFS, PUC-RJ, UnB, Cetene, IPEN, } \\
\text { Inmetro }\end{array}$ & 13 \\
\hline NANOCARBONO & UFMG & 73 & $\begin{array}{l}\text { UFMG, USP, UFABC, UFPR, UTFPR, UFOP, } \\
\text { UFV, UFJF, LQN/CDTN, UFU, UFSJ, UFF, } \\
\text { UFRJ, FURG, Unifra, UFPA, UFPB, UFMA, } \\
\text { Magnesita, Nacional, ENSP-FOC/Fiocruz, } \\
\text { CNEN/CDTN, UFMS, Inmetro }\end{array}$ & 24 \\
\hline
\end{tabular}




\begin{tabular}{|c|c|c|c|c|}
\hline \multicolumn{5}{|c|}{ INCTs DE NANOTECNOLOGIA E VÍNCULOS } \\
\hline INCT & Sede & $\begin{array}{c}\mathrm{N}^{\mathrm{a}} \mathrm{de} \\
\text { Pesquisadores }\end{array}$ & \multicolumn{2}{|l|}{ Instituições vinculadas } \\
\hline NAMITEC & $\begin{array}{l}\text { CTI/ } \\
\text { Unicamp }\end{array}$ & 162 & $\begin{array}{l}\text { CTI, CT-PIM, Embrapa, FEI, IFPB, IPT, } \\
\text { Mackenzie, PUC-RJ, UEM, UFBA, UFCG, } \\
\text { UFMG, UFPA, UFPI, UFRGS, UFRJ, UFRN, } \\
\text { UFSC, UnB, Unicamp, Unipampa, Univali, } \\
\text { USP }\end{array}$ & 23 \\
\hline NANOBIOTECNOLOGIA & UnB & 65 & $\begin{array}{l}\text { UnB, UFG, USP, UFMG, UFAC, UNIR, UFPI, } \\
\text { UFAM, UFU, UFAL, Embrapa, HRAN, } \\
\text { FK Biotech, Nanodynamics, Phitobios, } \\
\text { Nanophoton }\end{array}$ & 16 \\
\hline DISSE & PUC-RJ & 55 & $\begin{array}{l}\text { UFAM, Unifap, UFU, UFMG, PUC-Rio, } \\
\text { UFRJ, CTEx, IEAv, USP, UFSCar, Unicamp }\end{array}$ & 11 \\
\hline \multicolumn{2}{|l|}{ TOTAL } & 855 & & 163 \\
\hline
\end{tabular}

Fonte: Elaboração da autora.

Apresenta-se os dez INCTs identificados com suas caracteracterísticas e especificidades.

\section{Instituto Nacional de Ciência e Tecnologia de Catálise em Sistemas Moleculares e Nanoestruturados (CATÁLISE)}

O primeiro INCT contemplado, denomina-se como Instituto Nacional de Ciência e Tecnologia de Catálise em Sistemas Moleculares e Nanoestruturados, (CATÁLISE). Esse instituto era coordenado pelo professor Faruk José Nome Aguilera, sua sede estava instalada na UFSC, e seu quadro compunha-se de um grupo de 70 pesquisadores altamente qualificados com titulação correspondente a doutores (17\%), pós-doutores $(81,3 \%)$ e livres-docentes $(1,7 \%)$.

O CATÁLISE tinha "por finalidade a consolidação e promoção do desenvolvimento da área de catálise para as diversas atividades industriais e de pesquisa no país." (CNPq, 2016c).

Identificou-se entre os objetivos, a formação de pessoal de alto nível, principalmente mestres e doutores. A partir de sua formação, os pesquisadores atuavam em áreas circunscritas ao instituto e assumiam funções acadêmicas e de pesquisa nos diversos centros científicos e industriais do país (INCT, 2014a). A seguir, de modo sintético, apresenta-se as metas contempladas pelo CATÁLISE: 
- contribuir para o avanço do campo, da educação em geral e da ciência e tecnologia através de centros de excelência;

- promover a formação de professores e pesquisadores altamente qualificados;

- contribuir para a solução de vários problemas do mundo atual, principalmente no que tange ao desenvolvimento sustentável, o meio ambiente e a química verde o campo farmacológico;

- criar compromissos formais entre pesquisadores de áreas afins e de áreas afins e de áreas multidissiplinares, através de seminários, workshorps etc;

- fortalecer programas de graduação e de pós-graduação, através de visitas guiadas e laboratórios;

- promover a popularização da catálise junto a todos os que vierem a se interessar através de todas as atividades acima, mas em especial, através da página, núcleo e da marca INCT (INCT, 2014a).

Por ser importante em processos biológicos, a catálise é de grande interesse para a comunidade científica e tornou-se o foco de pesquisa deste instituto. "O estudo de sistemas catalíticos e o preparo de novos catalisadores contribuem, por exemplo, para a preparação de novos fármacos mais modernos e, ainda para o melhoramento da tecnologia industrial." Os temas principais de estudo desse instituto são: as "oleoquímicas e biodiesel; a catálise voltada à química fina; o desenvolvimento de enzimas artificiais e líquidos iônicos.” (CNPq, 2013c; INCT, 2014a).

Dos resultados obtidos com a atuação do CATÁLISE, pontuou-se na área de enzimas artificiais o desenvolvimento de sistemas que englobavam várias particularidades de reações enzimáticas. Esses sistemas mostraram elevada atividade catalítica e contribuíram para a elucidação de aspectos fundamentais de atuação de enzimas. Contemplaram também o desenvolvimento de novos materiais no âmbito dos líquidos iônicos e diferentes catalisadores metálicos mostraram-se altamente ativos no espectro da polimerização de olefinas.

A colaboração esteve sempre presente nas atividades deste instituto ao fortalecer o diálogo com as diversas empresas e ser responsável pela transferência de tecnologia representada por patentes. O esforço significativo do CATÁLISE, em divulgar a Ciência praticada para a sociedade, configurou-se meta constante. 
Vídeos, livros, áudio-livros e peças de teatro são incluídos como insumos produzidos (CNPq, 2013c).

As 14 instituições associadas do CATÁLISE, as quais representavam as regiões nordeste, centro-oeste, sul e sudeste do país, foram indicadas na sequência: UFSC; Universidade de São Paulo (USP) nas cidades de São Paulo, capital, e São Carlos; Universidade Estadual de Campinas (Unicamp); Universidade de Brasília (Unb); Universidade Federal de Santa Maria (UFSM); Universidade Federal de São Carlos (UFSCar); Universidade Federal do Rio Grande do Sul (UFRGS); Universidade Federal de Pelotas (UFPel); Universidade Federal de Minas Gerais (UFMG); Universidade Federal da Paraíba (UFPB); Universidade Federal de Alagoas (UFAL); Universidade Estadual do Norte Fluminense Darcy Ribeiro (UENF); Pontifícia Universidade Católica do Rio Grande do Sul (PUC-RS); e Universidade Federal de Blumenau (FURB) (CNPq, 2013c).

\section{Instituto Nacional de Ciência e Tecnologia em Materiais Complexos Funcionais (INOMAT)}

O Instituto Nacional de Ciência e Tecnologia em Materiais Complexos Funcionais (INOMAT), coordenado pelo professor Fernando Galembeck, foi o segundo instituto apresentado e sua sede estava instalada na Unicamp. Esse instituto possuía um grupo que compreendia 138 pesquisadores em vários estágios de formação. A titulação identificada desses pesquisadores destacou-se com a seguir: livre-docência com pós-doutorado (8\%), livre docência $(0,7 \%)$, pós-doutorado (62,3\%), doutorado (22,5\%), mestrado $(5,8 \%)$ e graduação $(0,7 \%)$.

O INOMAT definiu como missão "criar conhecimento na fronteira científica em materiais complexos e funcionais e utilizar esse conhecimento na criação de produtos e processos industriais inovadores, trabalhando com parcerias industriais." (CNPq, 2013c, p. 99). Estavam entre os seus objetivos a colaboração e contribuição para o avanço dessas fronteiras e sua associação e transformação em produtos e processos que gerassem riqueza. Esse instituto representou um salto qualitativo e quantitativo na agregação de um número elevado de pesquisadores de todos os níveis, como sinalizado, por buscar o aprofundamento nos temas investigados e a ampliação nas conexões internas e externas com agentes que atuam em seu entorno e possibilitavam o intercâmbio entre a academia e a indústria. 
Atento às exigências presentes no cenário mundial, o INOMAT focalizou e articulou demandas e oportunidades oriundas do mercado ou da comunidade científica. Ofereceu os resultados das atividades de pesquisa na busca pelo desenvolvimento e inovação em uma esfera global, com produtos que funcionavam de modo a "alimentar as atividades econômicas satisfazendo, ao mesmo tempo, necessidades da sociedade." (INCT, 2014e).

Com os objetivos propostos atingidos e amplamente superados, o INOMAT conquistou destaque no cenário nacional e possibilitou a execução de projetos de ampla repercussão na mídia interna no ano de 2010. Em anos posteriores seguiu-se a mesma trilha, o que possibilitou alcançar o cenário internacional. A troca de conhecimento e retroalimentação entre seus pesquisadores e as empresas permitiu manter acesa a chama da colaboração e do aprendizado mútuo e, como consequência, atingir resultado sempre frutífero para a sociedade.

Faziam parte do INOMAT seis instituições e um laboratório associado distribuídos nas regiões nordeste, sudeste e sul do país, a seguir indicadas: Unicamp; USP, Universidade Federal do Rio de Janeiro (UFRJ), Universidade Federal da Bahia (UFBA); Universidade Estadual de Maringá (UEM); Universidade Federal do Ceará (UFC); e o Laboratório Nacional de Nanotecnologia / Centro Nacional de Pesquisa em Energia e Materiais (LNNano/CNPEM) (CNPq, 2013c).

\section{Instituto Nacional de Ciência e Tecnologia dos Materiais em Nanotecnologia (INCTMN)}

O terceiro INCT da área de Nanotecnologia apresentado foi o Instituto Nacional de Ciência e Tecnologia dos Materiais em Nanotecnologia (INCTMN), o qual atuava sob a coordenação do professor Elson Longo da Silva. A sede desse instituto estava instalada na Universidade Estadual Paulista (Unesp) e possuía 74 pesquisadores com a seguinte titulação percentual: a seguinte titulação percentual: livre-docência com pós-doutorado (7\%); livre-docência (5,4\%); pós-doutorado (62,3\%); doutorado (17,6\%); e mestrado (1,3\%).

$\mathrm{O}$ foco de atenção desse instituto era a geração de conhecimentos por meio de estudos básicos em síntese, caracterização e processamento de materiais cerâmicos nanométricos. A aplicação desses materiais no desenvolvimento de 
cerâmicas eletrônicas de alto desempenho, incluindo dispositivos baseados em filmes finos, era a intenção do instituto ao realizar suas pesquisas.

A preocupação com o social estava presente nas atividades do INCTMN quando seus pesquisadores buscavam gerar conhecimento a partir de diferentes instituições, com o intuito da geração, descentralização e difusão do saber. Como consequência, obtiveram benefícios sociais e econômicos. A formação de recursos humanos, do nível fundamental à pós-graduação, por intermédio de suas divisões de pesquisa, foi outra frente de atuação do instituto ao atender as metas do Programa INCT ao qual estava vinculado (CNPq, 2013c).

Complementa ainda a linha de pesquisa do INCTM: a síntese química de materiais nanoestruturados em dispositivos para a conversão e armazenamento de energia; materiais não-cristalinos, ferroelétricos, semicondutores, eletrocrômicos e ópticos; e o crescimento de cristal; filmes e modelagem computacional. Os pesquisadores desse instituto atuam com a pesquisa básica e aplicada, ao proporcionar a geração de novos conhecimentos e a transferência sistemática para aplicações tecnológicas com objetivo educacional (CNPq, 2013c).

O INCTMN estava representado nas cinco regiões do país por dezesseis instituições: associadas: Unesp; UFSCar; USP; Instituto de Pesquisas Energéticas e Nucleares (IPEN); Universidade Federal de São Paulo (Unifesp); Universidade Federal do ABC (UFABAC); Universidade Federal do Rio Grande do Norte (UFRN); UFPB; UnB; Centro Brasileiro de Pesquisas Físicas (CBPF); Universidade Federal do Piauí (UFPI); Instituto Federal do Maranhão (IFMA); Universidade Federal de Goiás (UFG); Universidade Estadual de Goiás (UEG); Universidade Federal de Mato Grosso do Sul (UFMS); Universidade Estadual de Ponta Grossa (UFPG) (CNPq, 2013c).

\section{Instituto Nacional de Ciência e Tecnologia de NanoBioEstruturas e Simulação BioMolecular (NANOBIOSIMES)}

O Instituto Nacional de Ciência e Tecnologia de NanoBioEstruturas e Simulação BioMolecular (NANOBIOSIMES), o qual era coordenado pelo professor Benildo Souza Cavada, foi o quarto instituto a ser apresentado e sua sede está instalada na UFC. O número de pesquisadores total de 52 , com os seguintes percentuais de titulação: pós-doutores $(55,6 \%)$ e doutores $(44,4 \%)$. O NANOBIOSIMES tem como "foco de atuação a pesquisa multi/interdisciplinar no campo da 
nanobiotecnologia." (CNPq, 2013c, p. 101). A formação acadêmica dos pesquisadores que atuavam nesse instituto refletiu esse quadro e fazia-se presente na parceria entre químicos, bioquímicos e físicos que atuavam de forma articulada e integrada.

O NANOBIOSIMES estava representado em todas as regiões do país e buscava desenvolver atividades de pesquisa e formação de recursos humanos de alto nível. As temáticas exploradas por seus pesquisadores enquadravam-se "nas áreas estratégicas da Biotecnologia, Nanotecnologia e Saúde com pesquisas desenvolvidas através de projetos individuais e no escopo das redes de nanociência e nanotecnologia." (INCT, 2014f). As temáticas exploradas pelos pesquisadores do NANOBIOSIMES perpassavam:

transporte de cargas a dinâmica de torção no DNA, RNA e proteínas; o crescimento, caracterização e aplicações biotecnológicas de cristais e filmes de aminoácidos do DNA e RNA e proteínas; os fármacos e proteínas; a caracterização e simulações ab initio; a nanoestruturas de carbono, semicondutores e de outras materiais; e os biosensores (INCT, 2014f).

A pretensão do NANOBIOSIMES era direcionar suas atividades com o intuito de alcançar desenvolvimento em nanobioestruturas e simulação nanobiomolecular. Sua abordagem contemplou:

- uma visão multidisciplinar dos problemas em foco, contemplando fronteiras do conhecimento em física, química, bioquímica, medicina e farmacologia;

- aplicações tecnológicas e/ou desenvolvimento de processos no escopo de nanobioestruturas e simulação nanobiomolecular;

- pesquisas fundamentais inovadoras, que venham proporcionar novas possibilidades a serem exploradas no domínio da nanociência e nanotecnologia, bem como a continuação da formação de recursos humanos de alto nível em nanobioestruturas e simulação nanobiomolecular;

- colaborações inter-institucionais já estabelecidas na região Norte e Nordeste (destaque-se a maturidade e experiência dos grupos envolvidos no Ceará, Rio Grande do Norte, Alagoas, Maranhão, e Pará) (INCT, 2014f). 
Uniram-se esforços dos pesquisadores deste instituto no sentido de preparar, caracterizar e modelar nanomateriais e biomoléculas, assim como determinar as propriedades e avaliação da toxicidade em diferentes níveis de organização biológica.

Dentre os resultados e perspectivas do NANOBIOSIMES, destacou-se a análise estrutural de potenciais alvos farmacológicos baseados no estudo de lectinas vegetais. Permitiu-se, com a análise das moléculas de proteína de diversas leguminosas, a indicação de algumas aplicações biotecnológicas no diagnóstico e na terapêutica do processo inflamatório.

A consolidação de "uma linha de pesquisa em engenharia de cristais aplicada a fármacos com especial foco naqueles empregados para o combate das doenças negligenciadas” foi considerado um resultado animador para o instituto. Operou-se, desse modo, na formação dos recursos humanos para a atuação em frentes tão específicas no país como a doença de Chagas, a esquistossomose, a filariose, a tuberculose e a AIDS. Acrescentou-se ainda, a colaboração e consultorias com empresas farmoquímicas e laboratórios estatais (CNPq, 2013c).

As 13 instituições associadas que compunham o NANOBIOSIMES estavam também dispersas em todas as regiões do país, a saber: UFC; Universidade Federal do Rio Grande do Norte (UFRN); UFAL; UFSM; Universidade Federal do Pará (UFPA); Universidade Federal do Maranhão (UFMA); Universidade Veiga de Almeida (UVA); Universidade Estadual do Ceará (UECE); UFPB; Instituto Federal de Educação Ciência e Tecnologia do Ceará (IFCE), antigo Centro Federal de Educação Tecnológica do Ceará; Instituto Federal do Maranhão (IFM), antigo Centro Federal de Educação Tecnológica do Maranhão; Centro Universitário Franciscano (Unifra); Universidade Regional do Cariri (Urca) (CNPq, 2013c; INCT, 2014f).

\section{Instituto Nacional de Ciência e Tecnologia de Nanobiofarmacêutica (NANOBIOFAR)}

O desenvolvimento em medicamentos inovadores baseados em nanotecnologia era o foco de atuação do Instituto Nacional de Ciência e Tecnologia de Nanobiofarmacêutica (NANOBIOFAR), o quinto instituto apresentado. Coordenado pelo professor Robson Augusto dos Santos, sua sede está localizada na 
Universidade Federal de Minas Gerais (UFMG). Um grupo de 88 pesquisadores atuavam neste instituto e possuíam uma qualificação de alto nível.

A titulação dos pesquisadores do NANOBIOFAR representava em termos os seguintes percentuais: livre-docência com pós-doutorado (1,1\%); pós-doutorado $(68,2 \%)$; e doutores (30,7\%). O avanço expressivo alcançado pelo instituto no desenvolvimento de medicamentos nanoestruturados contribuiu para a consolidação da plataforma biotecnológica para o desenvolvimento de fármacos no país (CNPq, 2013c).

O NANOBIOFAR era "um centro de excelência em farmacologia pré-clínica e em tecnologias de formulação farmacêutica, com aplicação de nanotecnologia para liberação controlada de medicamentos, e criação de modelos animais para estudos biomédicos e experimentação.” (INCT, 2014b).

A intensa orientação da pesquisa farmacêutica para o desenvolvimento de inovações nesta área era o seu objetivo. O NANOBIOFAR agregava parcerias com empresas tecnológicas e públicas com o intuito de tornar-se uma plataforma que permitisse a prestação de serviços, assessoria e gestão da inovação na área de nanobioinformática. Foram apresentadas iniciativas que favoreceram o posicionamento estratégico do país na área tecnológica, as quais permitiram a atuação como "um catalisador de novas tecnologias, empresas, empregos e renda, através da transferência de tecnologia.” (INCT, 2014b).

As linhas de pesquisa que se destacaram no NANOBIOFAR foram as que estavam voltadas para o desenvolvimento de nanocarregadores inovadores para liberação controlada de fármacos e o desenvolvimento de líquidos iônicos como sistema de liberação de fármacos silenciadores específicos. A repercussão dos resultados obtidos com as pesquisas realizadas pelo instituto foi somada à conquista de prêmios e destaque jornalístico no âmbito local e nacional.

As instituições associadas que compunham o NANOBIOFAR eram 26, estavam localizadas nas regiões Nordeste, Centro Oeste, Sudeste e Sul do país e também em alguns países estrangeiros. Apresenta-se na sequência essa composição: UFMG; Pontíficia Universidade Católica de Minas Gerais (PUC-MG); UFG; Universidade Federal de Itajubá (Unifei); Universidade Federal de Juiz de Fora (UFJF); Universidade Federal de Lavras (UFLA); UFAL; Universidade Federal de Ouro Preto (UFOP); Instituto e Fundação Universitária de Cardiologia 
(IC-FUC); UFBA; Universidade Federal de São João Del Rey (UFSJ); Hospital Sírio-Libanês (HSL); Instituto do Coração da USP (Incor); Universidade Federal de Uberlândia (UFU); University of Akron (UA); Max Delbrück Center for Molecular Medicine (MDC); University of Florida (UFL); Bioss e University of Freiburg (BIOSS); University of Glasgow; Medical University of Graz (Medunigraz); École Polytechnique Fédérale de Lausanne (EPFL); Massachusetts Institute of Technology (MIT); University of Southern of Denmark (SDU); Universidade do Porto, Portugal (UP); Universidad Santiago de Compostella (USC); Pontificia Universidad Católica de Chile (UC) (CNPq, 2013c; INCT, 2014b).

\section{Instituto Nacional de Ciência e Tecnologia para Marcadores Integrados (INAMI)}

O estudo e desenvolvimento de processos e produtos de base nanotecnológica inovadores e competitivos era o foco de atenção do Instituto Nacional de Ciência e Tecnologia para Marcadores Integrados (INAMI). Ele era coordenado pelo professor Oscar Manoel Loureiro Malta, e o sexto INCT da área de Nanotecnologia a ser apresentado. Sua sede estava localizada na Universidade Federal de Pernambuco (UFPE). O objetivo do INAMI era produzir marcadores que servissem em diversas áreas do conhecimento e o grupo de pesquisadores do instituto perfazia o total de 138, cuja titulação, em termos percentuais a seguir se discrimina: livre-docência com pós-doutorado (4,6\%); pós-doutorado (60,2\%); doutorado (34,1\%); e graduação (1,1). A produção realizada pelo instituto estava focada em três eixos de ação: meio ambiente, segurança e saúde.

A promoção no desenvolvimento e na "colaboração científica entre grupos de pesquisa em Nanotecnologia pertencentes às instituições do Brasil participantes do INAMI" inseriu-se entre os seus objetivos. (MALTA, [2009]). Essa intenção tornou-se evidente na união de esforços entre as áreas de Biologia, Química, Física, Engenharia, Ciência de Matérias e Informática consolidou o objetivo muito bem definido do instituto. A seletividade associada à sensibilidade de marcação nas áreas prioritárias de meio ambiente, saúde e de segurança complementavam suas características (CNPq, 2013c). As principais linhas de pesquisa do INAMI foram:

sistemas moleculares para bioensaios; desenvolvimento de marcadores fotocrômicos com base em moléculas or- 
gânicas; dispositivos fotônicos; sistemas luminescentes para segurança; marcadores magnéticos; monitoramento magnético; marcadores eletroquímicos para células cancerígenas e material genético; desenvolvimento de sensores baseados em ressonância de plásmon superficial; imunomarcadores através de microscopia de força atômica para detecção do câncer de pele; e teoria e simulação computacional (CNPq, 2013c, p. 106).

Como resultados das ações executadas o INAMI destacou o desenvolvimento de um método inovador e um protótipo para fluoroimunoensaios com marcadores luminescentes baseados em complexos do íon neodímio (inovação tecnológica). O processo utilizando complexos de íon neodímio foi patenteado e encontra-se em andamento a fase de montagem de protocolos e protótipo (CNPq, 2013c).

Os frutos das atividades do INAMI foram positivos e serviram de incentivo para o planejamento de novas metas. A empresa LUNINTECH Marcadores Ópticos Ltda. foi consolidada em consonância com os objetivos do Programa INCTs e desenvolvidos carregadores de fármacos, de marcadores luminescentes para resíduos de tiro e detecção de falsificação de cédulas. A manutenção da linha de diálogo entre a sociedade e o instituto foi favorecida pelas exposições e cursos realizados.

As 13 instituições associadas que compunham o INAMI estavam localizadas nas regiões Nordeste, Sudeste e Centro-Oeste do Brasil e indicadas a seguir: Universidade Federal de Pernambuco (UFPE); UFOP; Universidade Estadual da Paraíba (UFPB); Universidade Federal de Campina Grande (UFCG); UFPB; UFAL; Universidade Federal de Sergipe (UFS); USP; Universidade Federal de Sergipe (UFS); Pontificia Universidade Católica do Rio de Janeiro (PUC-RJ); UnB; Centro de Tecnologias Estratégicas do Nordeste (Cetene); Instituto de Pesquisas Energéticas e Nucleares (IPEN); Instituto Nacional de Metrologia Qualidade e Estatística (Inmetro) (CNPq, 2013c).

\section{Instituto Nacional de Ciência e Tecnologia em Nanomateriais de Carbono (NANOCARBONO)}

O sétimo INCT apresentado foi o Instituto Nacional de Ciência e Tecnologia em Nanomateriais de Carbono (NANOCARBONO), coordenado pelo professor Marcos Assunção Pimenta, e possuía equipe considerada pioneira e líder 
no Brasil no estudo de nanomateriais de carbono. A sede desse instituto estava localizada na UFMG e sua composição compreendida uma rede formada por 74 pesquisadores com alta qualificação nos vários níveis de titulação com os seguintes percentuais de: livre-docência com pós-doutorado (4,1\%); pós-doutorado (76,7\%); doutorado (16,4\%); mestrado e graduação $(1,4 \%)$.

O trabalho no NANOCARBONO estava voltado para a realização da síntese, purificação e funcionalização dos nanomateriais de carbono. Outras atividades destacadas neste instituto foram: os "estudos de propriedades fundamentais, no desenvolvimento de modelos teóricos e simulações computacionais, na pesquisa em dispositivos e aplicações tais como sensores de gases, sensores biológicos, dispositivos foto-voltaicos, células combustíveis, e transístores de efeito de campo." (INCT, 2014c).

Os objetivos do NANOCARBONO estavam alinhados com as recomendações do Programa INCTs e voltados para:

- desenvolver investigações inéditas, relevantes e competitivas em nível internacional, nas fronteiras dos conhecimentos em física, química, biologia e aplicações em engenharia e medicina;

- desenvolver projetos de cooperação envolvendo empresas nacionais, com objetivo de gerar produtos, processos e ambientes inovadores, e de agregar valor a produtos e processos já desenvolvidos nessas empresas;

- formar recursos humanos de alta qualidade em diferentes níveis;

- produzir pesquisa de excelência em modo cooperativo e sinérgico e complementar envolvendo pesquisadores brasileiros de alto nível e colaboradores no exterior;

- estimular o desenvolvimento da pesquisa sobre nanomateriais de carbono em centros e universidades emergentes;

- transferir o conhecimento originado em nossa pesquisa para a sociedade, através de uma série de seminários, cursos presenciais e a distância, e outras atividades de divulgação (INCT, 2014c).

Em termos específicos, o NANOCARBONO definiu as etapas a serem cumpridas e com o instrumental existente e propôs-se a executá-las. As principais foram pontuadas a seguir e estavam voltadas para: 
- desenvolver e otimizar diferentes técnicas de produção de nanomateriais de carbono (nanotubos, grafenos e fullerenos);

- investigar fenômenos físicos fundamentais em nanomateriais de carbono utilizando técnicas de espectroscopia, microscopias eletrônica e de varredura, de transporte elétrico em condições extremas, e através de métodos teóricos de modelização e simulação;

- desenvolver e caracterizar compósitos a base de nanomateriais de carbono e desenvolver dispositivos eletrônicos, fotovoltaicos e sensores baseados nestes materiais;

- produzir material didático, oferecer cursos presenciais e online, e seminários de divulgação sobre nanomateriais de carbono.

- estudar e determinar a toxicidade e segurança ambiental dos nanomateriais de carbono (INCT, 2014c).

O desenvolvimento de investigações inéditas e relevantes em nível internacional nos campos da física, química e aplicações de nanomateriais de carbono foram alguns dos resultados obtidos pelo NANOCARBONO. A formação de recursos humanos; o fortalecimento das redes colaborativas no âmbito interno e externo; o estímulo ao desenvolvimento de pesquisas no campo de nano materiais de carbono; e a transferência de conhecimento para a sociedade foram resultados alentadores e simbolizaram o empenho do NANOCARBONO para alcançar sua perspectiva em esferas sociais, políticas e econômicas (CNPq, 2013c).

O NANOCARBONO compunha-se um conjunto de 22 instituições e duas empresas associadas em seu contexto de atuação, dispersas entre as cinco regiões do país com o predomínio da região sudeste e são indicadas a seguir: UFMG; Centro de Desenvolvimento da Tecnologia Nuclear (CDTN); Fundação Oswaldo Cruz (FIOCRUZ) / Escola Nacional de Saúde Pública (ENSP); Universidade Federal do Rio Grande (FURG); UFABC; Universidade Federal Fluminense (UFF); UFJF; UFMA; UFMS; UFOP; UFPA; UFPB; Universidade Federal do Paraná (UFPR); UFRJ; UFSJ; UFU; Universidade Federal de Viçosa (UFV); Unifra; USP; Universidade Tecnológica Federal do Paraná (UTFPR); Magnesita Refratários S/A (Magnesita); Nacional de Grafite Ltda. (Nacional) (CNPq, 2013c; INCT, 2014c). 


\section{Instituto Nacional de Ciência e Tecnologia de Sistemas Micro e Nanoeletrônicos (NAMITEC)}

O Instituto Nacional de Ciência e Tecnologia de Sistemas Micro e Nanoeletrônicos (NAMITEC) foi o oitavo instituto a ser apresentado. Coordenado pelo professor Jacobus Willibrordus Swart, esse instituto possuía uma rede que congregava 162 pesquisadores, a maior identificada entre os institutos da área de Nanotecnologia em número de pesquisadores. Composto pelas principais instituições que desenvolviam nano e microeletrônica no Brasil (INCT, 2016c), o NAMITEC estava sediado no Centro de Tecnologia da Informação Renato Acher (CTI). A equipe de pesquisadores, de alto gabarito detinha titulação nos percentuais correspondente a: livre-docência com pós-doutorado (3,1\%); livre- docência (2,4\%); pós-doutorado (46\%); doutorado (43\%) e mestrado (5,6\%).

Os objetivos do NAMITEC englobavam: "o desenvolvimento de pesquisas e ações no estudo de redes de sensores sem fio; sistemas embarcados; projetos de circuitos integrados; estudos de dispositivos, materiais e técnicas de fabricação; e formação de recursos humanos". Estes objetivos aliavam-se à missão do instituto de gerar, aplicar e disseminar conhecimentos de micro e nanoeletrônica, desenvolver competências, promover inovações e atender às necessidades da sociedade (INCT, 2014d).

A ampla atuação no campo da micro e nanoeletrônica permitiu o retorno dos esforços e aplicação em áreas como: "tecnologia da informação e comunicação; comunicação biomédica e vida assistida - redes veiculares - ambientes inteligentes; indústria automotiva e aeroespacial; produção, distribuição e uso de energia; e ecologia”. Os resultados foram animadores e reverteram-se para o mercado e sociedade, por ser altíssima a relevância econômica e social dos sistemas micro e nano eletrônicos. A interação com a indústria tem sido muito produtiva e o depósito de patentes crescente (CNPq 2013c, p. 107; INCT, 2014d).

Destacaram-se a seguir as oito áreas de atuação do NAMITEC: redes de sensores sem fio; materiais e técnicas de fabricação; projeto de CL’s e de bibliotecas de IP's; EDA - projeto automático de circuitos integrados; dispositivos semicondutores; formação de recursos humanos; e transferência de tecnologia (CNPq, 2013; INCT, 2014d). 
As 23 instituições associadas que formam a rede do NAMITEC estavam espalhadas por todas as regiões do país e englobavam centros de pesquisa e universidades. Elas foram descriminadas como: CTI; Centro de Ciência, Tecnologia e Inovação do Polo Industrial de Manaus (CT-PIM); Embrapa; Faculdade de Engenharia Industrial (FEI); Instituto de Pesquisas Tecnológicas do Estado de São Paulo (IPT); Instituto Federal da Paraíba (IFPB); PUC-RJ; Unb; USP; Universidade do Vale de Itajaí (Univali); Unicamp; UEM; UFBA; UFCG; UFMG; UFSC; Universidade Federal do Pampa (Unipampa); UFPA; UFPI, UFRJ; UFRN; UFRGS; Universidade Presbiteriana Mackenzie (Mackenzie) (CNPq, 2013c; INCT, 2014d).

\section{Instituto Nacional de Ciência e Tecnologia de Nanobiotecnologia do Centro-Oeste e Norte (NANOBIOTECNOLOGIA)}

O nono instituto a ser apresentado foi o Instituto Nacional de Ciência e Tecnologia de Nanobiotecnologia do Centro-Oeste e Norte (NANOBIOTECNOLOGIA). A rede de atuação composta por uma equipe de 65 pesquisadores cuja titulação, em termos percentuais, correspondente a: livre-docência com pós-doutorado (3,1\%); pós-doutorado (61,5\%); doutorado (29,2\%); mestrado (4,6\%); e especialização (1,6). O professor Ricardo Bentes de Azevedo era o responsável pela coordenação desse instituto, cuja sede se situava na UnB.

O escopo de pesquisa deste instituto envolvia: a realização dos cálculos das propriedades básicas de nanoestruturas; rotas de produção e caracterização de complexos nanoestruturados construídos a partir do acoplamento de drogas, ou biomoléculas a materiais nanoestruturados (magnéticos e não magnéticos); e a realização de testes pré-clínicos com os complexos para aplicação na saúde humana, animal e aplicações ambientais (CNPq, 2013c, 2016b).

O NANOBIOTECNOLOGIA incluía, ainda no seu âmbito de pesquisa "estudos sobre moléculas e compostos da biodiversidade brasileira e suas aplicações nanotecnológicas." As linhas de pesquisa contempladas eram: síntese e caracterização de complexos nanoestruturados; aplicações de materiais nanoestruturados; e nanotoxicologia (CNPq, 2013c, p. 103).

A formação de recursos humanos foi um dos grandes resultados do NANOBIOTECNOLOGIA, bem como a criação de um curso de pós-graduação em na- 
nociência e nanobiotecnologia. A sua produção científica e técnica tornou-se um resultado expressivo e consequência dos recursos humanos formados.

A saúde bucal tem muito a agradecer às pesquisas realizadas pelo NANOBIOTECNOLOGIA, pois delas já resultaram nanoemulsões para o tratamento da cárie em humanos. Os cuidados com o pré-câncer e câncer de pele foram também contemplados com as nanoemulsões. Os testes pré-clínicos foram realizados, e iniciados os clínicos em humanos e cães. Outros experimentos com nanopartículas vêm sendo testados em cães e camundongos (CNPq, 2013c).

A colaboração entre os pesquisadores do NANOBIOTECNOLOGIA e as empresas associadas fez-se marcante e têm possibilitado ganhos para as duas partes com o depósito de patentes, lucro econômico e construção de conhecimento. A repercussão do trabalho do NANOBIOTECNOLOGIA ganha cada vez mais a esfera internacional como frutos dessa repercussão, pesquisadores foram contemplados em projetos no exterior.

A sociedade também ganhou com a atuação do NANOBIOTECNOLOGIA e está um pouco mais ciente do que é a nanotecnologia. A produção de um vídeo desse instituto sobre a temática foi divulgado na internet e vem atingindo ampla audiência, utilizado inclusive como material didático para discussão em escolas públicas de Goiás, Rondônia e demais áreas do Distrito Federal (CNPq, 2013c). Desse modo, realizou-se a divulgação científica, uma das metas do Programa INCT. Somou-se a essa atividade: formação de recursos humanos com alta qualificação para a academia e mercado; produção científica e tecnológica de qualidade; e produção de inovação fruto da colaboração entre as empresas associadas e os pesquisadores do instituto. Essas metas muito bem cumpridas por esse instituto e desenvolvidas com perspectiva de continuidade.

A localização geográfica da sede do NANOBIOTECNOLOGIA, em uma região central no Brasil foi um aspecto favorável. Ele agregou 12 instituições de ensino e pesquisa e quatro empresas associadas distribuídas entre as 5 (cinco) regiões do país. Essa rede era composta pelos seguintes atores institucionais: UnB; UFG; UFMG; UFU; UFAC; UNIR; UFPI; UFAL; UFAM; USP; Embrapa; HRAN; Nanodynamics; FK Biotech; Phytodios e Nanophoton (CNPq, 2013c). 


\section{Instituto Nacional de Ciência e Tecnologia de Nanodispositivos Semicondutores (DISSE)}

O décimo e último INCT da área de Nanotecnologia apresentado foi o Instituto Nacional de Ciência e Tecnologia de Nanodispositivos Semicondutores (DISSE), coordenado pela professora Patrícia Lustoza de Souza, cuja sede estava localizada na PUC-RJ. Esse instituto era constituído por uma rede com 55 pesquisadores, altamente qualificados e com titulação que correspondia, em termos percentuais a: livre-docência com pós-doutorado (1,9\%); pós-doutorado (49\%); doutorado (29,1\%) e mestrado (20\%).

O DISSE desenvolvia estudos "de nanoestruturas semicondutoras para a confecção de dispositivos optoeletrônicos com ênfase em fotodetectores de infravermelho médio e dispositivos inéditos baseados em efeitos puramente quânticos ainda não explorados." (CNPq, 2008).

O resultado obtido com as pesquisas desenvolvidas pelo DISSE eram de extrema relevância para o país e esse caracteriza um grande passo para o domínio de tecnologia cujo valor é estratégico, por possibilitar a utilização dos seus insumos em várias aplicações, em armamento militar inclusive. Provavelmente esse tipo de aplicação seja a causa da dificuldade encontrada para obtenção da matéria-prima no mercado internacional.

O domínio de uma tecnologia desse tipo supriria a carência existente no mercado nacional e conduziria à independência do país nesse aspecto. Essas aplicações, derivadas dos insumos produzidos, despertaram interesse em diversos segmentos estratégicos para a Ciência, Tecnologia e Inovação como: tecnologias de informação e comunicação, petróleo, agronegócio, mudança climática, programa espacial e defesa nacional. Abriu-se uma oportunidade para colocar o país em igualdade tecnológica com outras nações.

A missão do DISSE estava alinhada com o Programa INCTs e contemplava a pesquisa, a formação de recursos humanos, a transferência de conhecimentos para a sociedade, para o setor empresarial e para o governo. Atentou-se para a plena execução dessas metas ao se designar um pesquisador do instituto como responsável direto pela coordenação de cada uma (CNPq, 2008b). As principais linhas de pesquisa do DISSE eram: "desenvolvimento de nanodispositivos semicondutores; estudo de propriedades fundamentais em nanoestruturas para 
nanodispositivos; crescimento de pontos quânticos auto organizados; novos fenômenos físicos em pontos quânticos e microcavidades visando dispositivos inéditos." (CNPq, 2013c, p. 104).

As "células solares para geração de energia renovável e os fotodetectores de infravermelho para ligações em detecção de gases tóxicos e imageamento térmico" foram os dispositivos escolhidos como prioritários nesta empreitada em busca da soberania tecnológica do país (CNPq, 2013c, p. 104). A relevância, científica, tecnológica, econômica e estratégica que as pesquisas desenvolvidas por este INCT representam é incontável.

Entre os resultados práticos obtidos destacaram-se o desenvolvimento de vários fotodetectores de infravermelho e protótipos de aparelhos para detecção de gases utilizando-se sensores de infravermelho, como chips com variadas estruturas de circuitos integrados analógicos, digitais e mistos. Um desses foi o desenvolvimento de chip de silício para leitura de fotodetectores, denominado como Chip IR1, o qual obteve repercussão nos diversos canais de divulgação científica nacional (CNPq, 2013b, 2013c).

Como em outros INCTs, a colaboração realizada entre os pesquisadores do DISSE e os diversos segmentos da sociedade foi um aspecto preponderante para o sucesso das pesquisas desenvolvidas. Aliou-se a ela o empenho pela formação de recursos humanos de alto nível e a preocupação pela transferência de conhecimento para a sociedade. Viabilizou-se esta atividade através do desenvolvimento de vídeos de instrução e divulgação de temas contemplados pelo DISSE e kits experimentais para serem distribuídos em museus e escolas de ensino médio da rede pública (CNPq, 2013c).

O DISSE possuía 11 instituições associadas de ensino e pesquisa trabalhando em pesquisas com a intenção do aprimoramento da tecnologia que permitia "a visão noturna, telecomunicações no espaço livre, detecção de gases tóxicos, imageamento ambiental para localização de incêndio”, entre outras aplicações. (MOTTA, 2011). Essas instituições estavam distribuídas entre as regiões norte e sudeste do país e foram identificadas como: PUC-RJ; Universidade Federal do Amapá (Unifap); UFAM; UFU; UFMG; UFRJ; Centro Tecnológico do Exército (CTEx); Instituto de Estudos Avançados (IEAv); USP; Unicamp; e UFSCar (CNPq, 2013c, p. 104). 
Contemplou-se, desse modo, a indicação da natureza do grupo formado pelos INCTs da área de Nanotecnologia. Ao se cumprir essa etapa da pesquisa, detalhou-se a política pública Programa INCTs, representado pelos institutos da área de Nanotecnologia. A apresentação dos resultados da implementação de uma política pública voltada para a CT\&I foi realizada, etapa importante para a execução da pesquisa e realização dos objetivos precedentes.

Inferiu-se, com os resultados apresentados, que o Programa INCTs conquistou o objetivo esperado e, apesar de alguns contratempos durante o processo, cumpriu sua meta principal de "contribuir para o desenvolvimento da pesquisa e criar patentes para o país, promovendo uma sinergia entre grupos de pesquisadores de diferentes instituições e áreas do conhecimento." (PORTAL, 2013).

Apresenta-se a seguir, as práticas e redes colaborativas para inovação dos INCTs investigados. 


\section{PRÁTICAS E REDES COLABORATIVAS PARA INOVAÇÃO NOS INCTS DA ÁREA DE NANOTECNOLOGIA}

As práticas colaborativas desenvolvidas nos diversos campos científicos repercutem na manutenção de uma atividade de excelência. Influenciam ainda, na produção e fornecimento da informação científica, tecnológica e de inovação em uma sociedade diferenciada, a qual sofre os efeitos das transformações tecnológicas, político-institucionais e de inovação.

Essas práticas são ainda atividades científicas realizadas pelos pesquisadores que demandam um aparato científico e tecnológico adequado para que sua realização forneça os insumos esperados. Conforme Albagli e colaboradores (2013) as práticas colaborativas contemporâneas são "expressas em noções tais como: redes de conhecimento, coinovação, cocriação, produção peer-to-peer, crowdsourcing, inovação aberta, inovação social, open Science, entre outras, cada qual com seu significado específico".

Os ambientes digitais contemporâneos desenvolvidos com o boom tecnológico favorecem a realização das práticas colaborativas e se constituem no diferencial que as distingue das práticas tradicionais. A busca pelo entendimento concreto sobre essas práticas e sua efetiva ocorrência nos INCTs da área de Nanotecnologia originou a seguinte questão da pesquisa: quais são as práticas científicas colaborativas para inovação realizadas e as redes colaborativas existentes nos institutos da área de Nanotecnologia? Respondê-la foi um dos objetivos específicos propostos e contemplados na pesquisa que derivou esse livro. 
O objetivo foi respondido e as práticas e redes colaborativas pertinentes ao questionamento identificadas. As práticas mais recorrentes nos institutos foram a formação de recursos humanos e à colaboração científica tradicional, uma evidência de que apesar das inovações tecnológicas que ocorrem na sociedade contemporânea e inserção de novas práticas colaborativas no âmbito acadêmico, a tradição ainda prevalece, acompanhada da preocupação com a formação qualificada de seus pares. As redes colaborativas identificadas foram várias: rede de colaboração dos pesquisadores dos INCTs da área de Nanotecnologia fomentada pela produção científica; a rede das práticas colaborativas como resultado das interações entre os INCTs e os atores e actantes que a compuseram; a rede dos INCTs e artefatos que compuseram a infraestrutura $e$-Science; a rede da cadeia de inovação composta pelas etapas contempladas pelos institutos em suas interações; a rede dos INCTs e as políticas públicas que sustentaram o Programa e seu entorno; a rede das universidades; das instituições; das organizações; dos agentes de fomento; das empresas; dos laboratórios; dos hospitais, e muitas outras identificadas no conglomerado investigado.

As fontes utilizadas foram importantes para analisar os indicadores nesta etapa da investigação, como a colaboração, a internacionalização e a inovação, aspectos pertinentes às atividades colaborativas e subsídios usados para obtenção da resposta que satisfez ao questionamento realizado.

Esta seção foi subdividida em duas subseções que permitiram uma melhor ordenação dos resultados apresentados e analisados. A primeira ateve-se às práticas colaborativas identificadas nos INCTs da área de Nanotecnologia. A segunda ficou com o encargo de apresentar as redes colaborativas identificadas nos INCTs e os atributos que caracterizaram os atores/actantes que formaram o coletivo representado pelos institutos e o seu entorno.

\section{Práticas colaborativas nos INCTs}

A percepção dos pesquisadores dos INCTs acerca das práticas colaborativas iniciou os questionamentos. Essa etapa fez parte de um conjunto de procedimentos que buscavam conhecer, cada vez mais, o perfil dos pesquisadores que representavam a área. 
Quando questionados sobre os modelos cooperativos de produção do conhecimento que conheciam ou com os quais tinham familiaridade, os respondentes sinalizaram as redes de especialistas (37,4\%); as redes de informação (29,7\%); as redes internas de gestão de conhecimento (27,5\%); as redes de conhecimento formal (29,7\%) e as alianças estratégicas (29,7\%). A opção nenhuma das alternativas $(31,9 \%)$ e as comunidades de prática (CoPs) (1\%), as últimas dos modelos cooperativos com o menor percentual de respondentes. O Gráfico 9 ilustrou o resultado analisado.

Gráfico 9 - Modelos cooperativos de produção do conhecimento

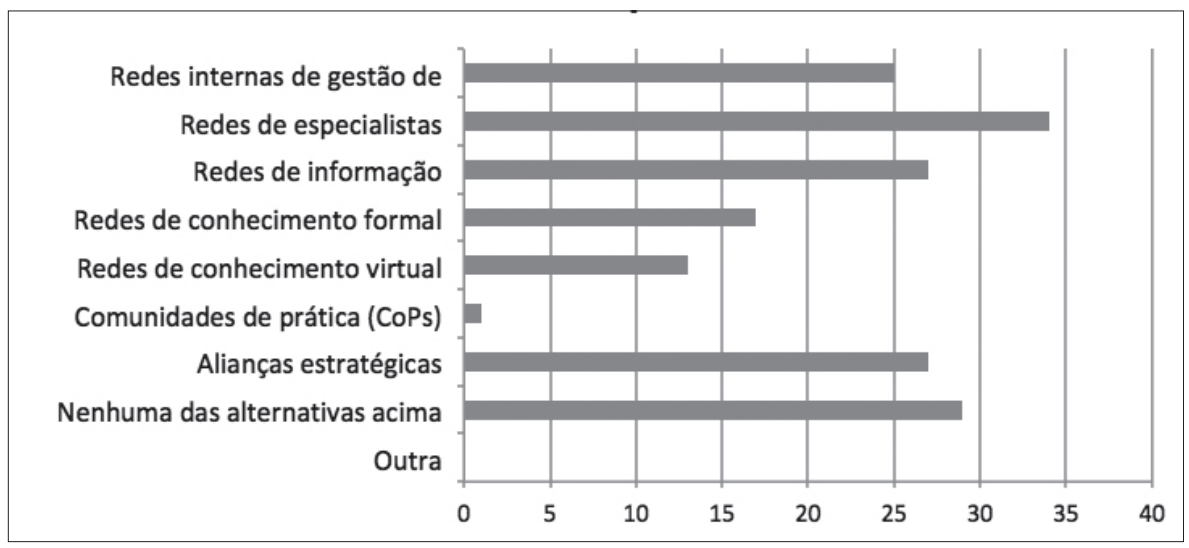

Fonte: Elaboração da autora.

O resultado que contemplou as redes de especialistas como maioria dos respondentes não causou surpresa, considerando-se que os INCTs da área de Nanotecnologia constituem-se, por natureza, em uma rede de especialistas. Entretanto, surpreendeu o percentual de $31 \%$ indicado pelos pesquisadores para nenhuma das alternativas apresentadas. Como entender uma parcela do grupo de pesquisadores, a qual trabalha em redes colaborativas, cujo nível de especialização é alto, conforme contemplado no levantamento da titulação acadêmica, não se enquadrar em nenhum dos modelos cooperativos apresentados?

Ocorreram suposições que pudessem justificar uma ocorrência significativa de pesquisadores que em nenhum dos modelos cooperativos apresentados se enquadram. Dentre essas a de que eles poderiam estar desenvolvendo seu traba- 
lho de modo individual, ou à margem dos institutos, apesar de estarem oficialmente ligados a eles. Isso contradiria a lógica do trabalho proposto pelo Programa dos INCTs que prima pelas redes colaborativas e a composição representada pelos institutos.

Pensou-se ainda que eles pudessem não estar familiarizados com o vocabulário apresentado no questionamento, razão pela qual preferiram não pontuar o que não conheciam. Ou, a despeito de fazerem parte dos modelos apresentados, não estarem preocupados com rótulos ou denominações, o que os faziam assinalar desconhecimento sobre eles. Não foi identificada outra suposição plausível para o resultado.

Ao questionar-se sobre a efetiva colaboração realizada entre os pesquisadores dos INCTs ou colegas da área de atuação obteve-se o resultado pontuado no Gráfico 10.

Gráfico 10 - Colaboração nos INCTs de Nanotecnologia

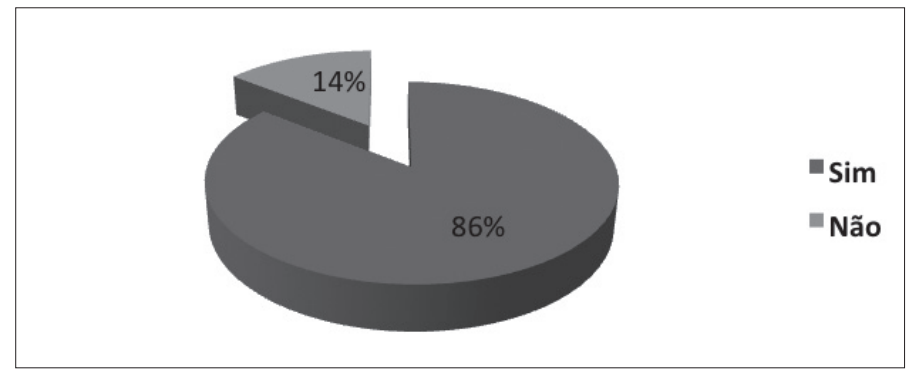

Fonte: Elaboração da autora.

Os pesquisadores responderam, em ampla maioria, que colaboraram ou estão colaborando com os seus pares; a assertiva (85,7\%) e a negativa (14,3\%). Esse resultado é coerente com o perfil da área de Nanotecnologia, considerada altamente colaborativa. Os projetos colaborativos desenvolvidos ou em desenvolvimento, indicados pelos pesquisadores, contemplaram as diversas aplicações que a área realizou e corresponderam às implementações identificadas na literatura científica consultada.

Dentre os projetos pontuados nas respostas fornecidas pelos pesquisadores destacam-se: desenvolvimento de sensores infravermelho; sistemas de computa- 
ção baseados em redes de sensores; síntese de dispositivos de liberação controlada de fármacos e similares; caracterização de grafenos e nanotubos de carbono; marcadores para fins diagnósticos de doenças; encapsulamento optoeletrônico com micro e nanotecnologias; estrutura eletrônica de materiais 2D; desenvolvimento de nanocompósitos para remoção de metais pesados da água;

avaliação de atividades biológicas de frações proteicas de peçonhas, entre muitos outros.

A identificação das práticas colaborativas efetivas desenvolvidas pelos pesquisadores foi objeto de análise em dois grupos de dados empíricos; o resultado do questionário online e da análise de conteúdo do relatório de acompanhamento de projeto.

No questionário online, a pergunta sobre as práticas colaborativas desenvolvidas contemplou a colaboração científica como a mais desenvolvida (85,7\%) pela ampla maioria entre os respondentes; as redes de conhecimento (28,6\%); seguida da cocriação $(20,9 \%)$ e da coinovação $(20,9 \%)$, as duas últimas em mesmo percentual. Obtiveram-se os seguintes percentuais de indicações para produção peer-to-peer (13,2\%), inovação aberta (7,7\%) e a inovação social (4,4\%). A prática de crowdsourcing (1,1\%) apenas das respostas e a opção nenhuma das alternativas (5,5\%). O Gráfico 11 pontuou o resultado identificado.

Gráfico 11 - Práticas colaborativas - Questionário online

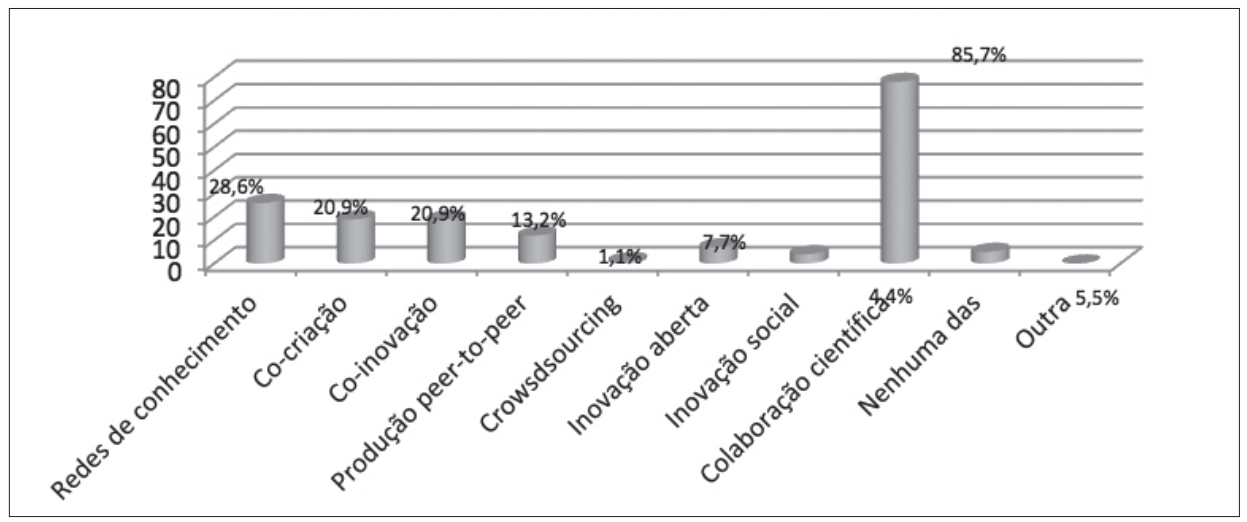

Fonte: Elaboração da autora. 
$\mathrm{Na}$ análise correspondente aos dados dos relatórios de acompanhamento de projeto, os resultados contemplaram as informações provenientes dos INCTs da área de Nanotecnologia selecionados como amostra. As práticas colaborativas identificadas foram relacionadas conforme indicado no relatório. É importante registar que as ocorrências podem ser simultâneas por se tratarem de práticas colaborativas, resultantes de diversos tipos de interações. Em uma parceria colaborativa realizada, pode ocorrer ao mesmo tempo, a colaboração científica, o compartilhamento de recursos, uma consultoria, entre outras. Contudo, para a quantificação, levou-se em consideração os atores envolvidos na interação, as atividades predominantes do grupo em análise e a informação indicada no relatório. O Gráfico 12 contemplou as práticas identificadas.

Gráfico 12 - Práticas colaborativas - Relatórios

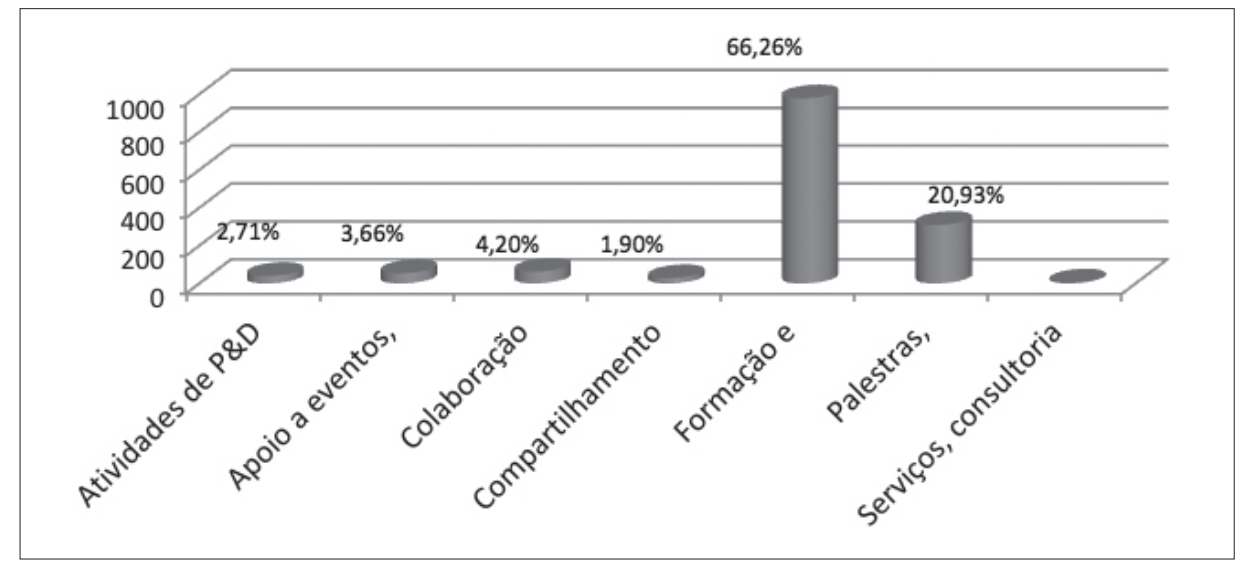

Fonte: Elaboração da autora.

De modo diverso ao que foi contemplado no questionário online, à prática colaborativa mais indicada foi a formação e capacitação de recursos humanos, com o percentual de $66,26 \%$. A segunda mais indicada foi a realização de palestras, conferências, colóquios, seminários etc, com o percentual de 20,93\%; a esse resultado atribui-se a forte atuação dos INCTs na formação e capacitação de recursos humanos. Informações passíveis de corroboração nos resultados que serão apresentados nesta seção, na sequência. 
Entretanto, isto não quer dizer que a prática de colaboração científica, indicada pela maioria dos respondentes do questionário online, esteja fora do contexto. Pelo contrário, o resultado obtido reforça sua presença, pois se existe formação e capacitação de recursos humanos e apresentação de palestras, conferências, colóquios, simpósio, entre outros eventos, a colaboração científica está implícita na atividade. Isso caracteriza evidência de que a tradição ainda prevalece, apesar das inovações tecnológicas que ocorrem na sociedade contemporânea e da inserção de novas práticas colaborativas no âmbito acadêmico

Esse resultado manteve-se em sintonia com as observações pautadas pelos coordenadores dos INCTs nas entrevistas online; quando eles foram questionados sobre as práticas colaborativas realizadas nos institutos e a existência de algum diferencial após o advento das tecnologias de comunicação e informação e da $e$-Science, eles responderam da seguinte forma:

- basicamente nós continuamos desenvolvendo como sempre foi feito, houve alguma melhora nesse sentido, nós temos um site, no site nós colocamos algumas informações e tal [...] nós continuamos no mesmo processo que vinhamos fazendo e que já se sabia fazer. Na forma tradicional basicamente;

- [...] nem um nem outro, nós gradualmente vamos incorporando e usando mais as ferramentas. Creio que as ferramentas estão melhores e algumas não avançaram nesse aspecto. Portanto, nós usamos a ferramenta que temos, porque não temos muito acesso. Então acho que gradualmente vai aumentando essa utilização;

- [...] se houve mudança foi pequena, é claro que sempre tem as pessoas que interagem com essas ferramentas, mas na minha opinião, na minha avaliação que é assim, é qualitativa e não quantitativa, porque eu não tenho os números para te passar aqui...mas na minha avaliação essas ferramentas por enquanto, contribuíram pouco na colaboração. Acho que o encontro presencial através dos encontros anuais foram mais efetivos que essas ferramentas;

- no caso da parte colaborativa o que essas novas tecnologias auxiliam é na comunicação propriamente dita. E nós podemos estar em contato direto por Skype praticamente diariamente com todos os grupos que estão espalhados pelo país. Nós queremos mostrar os resultados e discutir os resultados, colocamos no Skype compartilhamos a tela e podemos promover aquela discussão sem a necessidade de deslocamento. Isso na realidade 
acelera o processo da pesquisa, porque você consegue discutir de uma forma mais eficaz, mais rápida;

- então na minha opinião, em termos de colaboração dentro do âmbito do INCT eu senti que foi mais efetiva o encontro presencial, os encontros anuais, surgiram muitas colaborações nesses encontros mais do que nessas ferramentas, nesses sites.

Inferiu-se, com os resultados obtidos, que os pesquisadores dos institutos consultados desenvolvem práticas colaborativas, contudo, a realizam na maioria das vezes, de forma tradicional. Apesar dos recursos tecnológicos presentes na sociedade contemporânea e das práticas colaborativas desenvolvidas em ambientes virtuais, os pesquisadores analisados indicaram que desenvolvem a colaboração científica tradicional e utilizam os recursos tecnológicos mais efetivamente, nas comunicações virtuais realizadas.

Ao utilizarem os recursos tecnológicos nas suas atividades científicas, os pesquisadores o fazem, mas não de modo acentuado. Apesar de serem pesquisadores da alta tecnologia, utilizam-na em suas práticas de forma moderada. Os recursos colaborativos virtuais utilizados, em sua maioria, resumem-se a artefatos para comunicação como correio eletrônico, plataformas virtuais para videoconferência ou conversas online, a exemplo do software Skype e sistemas internos desenvolvidos no âmbito do instituto, como o webcs.

As outras formas de práticas colaborativas pontuadas pelos pesquisadores não obtiveram um percentual que permitisse situar o grupo investigado como grandes utilizadores de dispositivos produzidos para ambientes colaborativos virtuais. Apesar da prática de produção peer-to-peer (P2P) ter obtido o percentual de $13,2 \%$, essa ainda é pouco significativa dentro de uma comunidade que possui um perfil de pesquisadores envolvidos com a alta tecnologia. O crowdsourcing, o qual conforme Oliveira (2012, p. 1), "é um modelo de criação coletiva e em massa, cuja essência é a cooperação entre os participantes”, obteve o percentual irrisório de apenas $1,1 \%$.

Entretanto, ao se fazer um recorte do resultado e analisar os INCTs selecionados na amostra, pode-se perceber que as práticas colaborativas mais frequentes, realizadas especialmente entre institutos de ciência e tecnologia, universidades e empresas fizeram-se presentes nos INCTs. Ao se destacar as práticas realiza- 
das com maior frequência pelos institutos constatou-se que no NAMITEC, NANOBIOTECNOLOGIA e NANOCARBONO o registro da predominância for formação e capacitação de recursos humanos. Nesses institutos identificou-se a realização de quase todas as práticas. De modo geral, a menos contemplada foi a realização de consultorias.

Nos INCTs, registrou-se uma ocorrência simultânea de muitas atividades, apesar de a formação e capacitação de recursos humanos ter sido o "carro-chefe". A colaboração científica esteve presente em todos os INCTs, conforme se pode constatar no Gráfico 13.

Gráfico 13 - Atividades colaborativas mais recorrentes

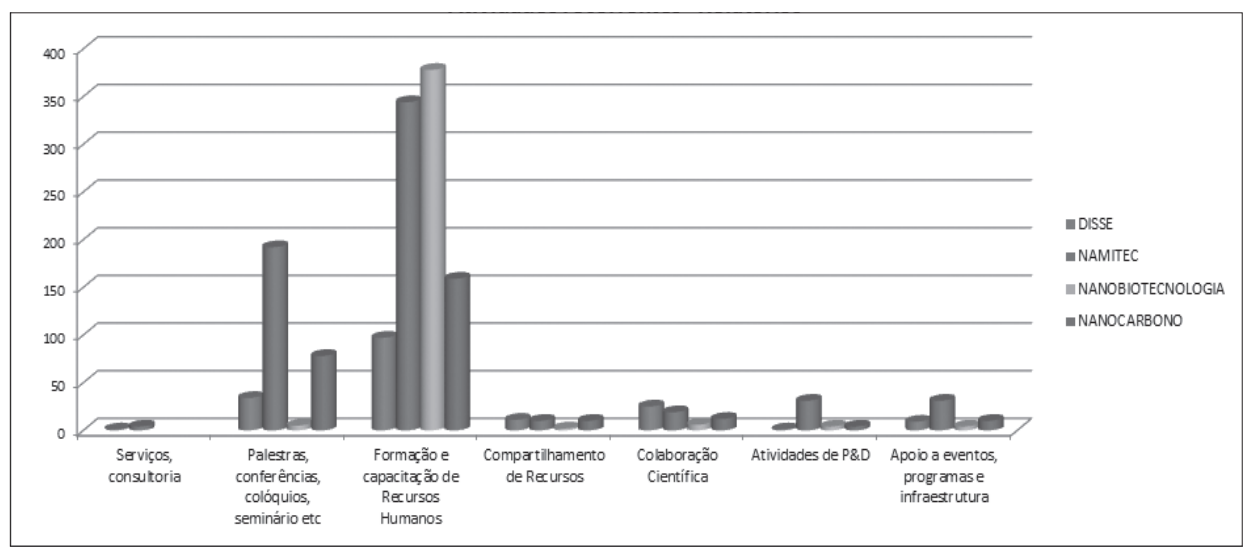

Fonte: Elaboração da autora.

Com a identificação dos modelos cooperativos conhecidos, confirmação da realização da colaboração pelos pesquisadores, identificação das práticas desenvolvidas, o próximo questionamento foi sobre os benefícios esperados com a colaboração realizada.

O compartilhamento de recursos financeiros e suporte à infraestrutura de pesquisa foi o benefício que obteve o maior percentual de indicações, com 81,3\% das respostas. Levando-se em consideração o momento de crise econômica e política por que passa o país, esse foi um benefício sinalizado e utilizado de modo amplo pelos pesquisadores. Essa foi a alternativa encontrada para não perder esforços empreendidos no desenvolvimento de pesquisas e criar bases cada 
vez mais sólidas entre os parceiros conquistados. Este resultado foi apresentado no Gráfico 14.

Os demais benefícios esperados com as práticas colaborativas foram pontuados com os seguintes percentuais: aumento da qualidade e visibilidade da pesquisa (76,9\%); transferência de conhecimento e habilidades (73,6\%); participação em grandes projetos (69,2\%); formação de novos pesquisadores $(68,1 \%)$; e contribuição para o rápido crescimento do conhecimento científico $(57,1 \%)$.

\section{Gráfico 14 - Práticas colaborativas - Benefícios}

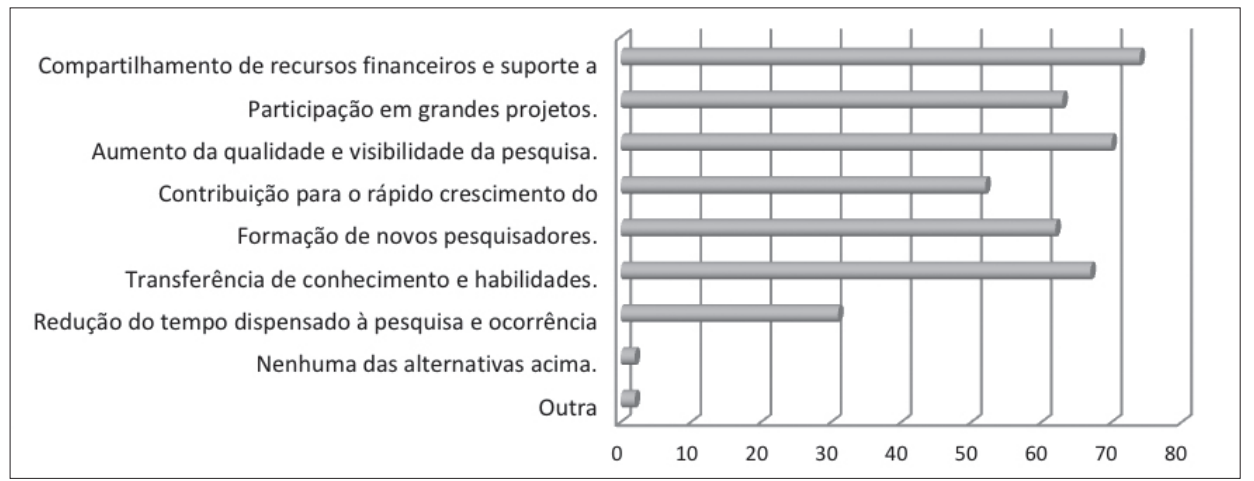

Fonte: Elaboração da autora.

A expectativa em torno dos benefícios proporcionados pelas práticas colaborativas foi confirmada de acordo com a necessidade premente das instituições for financiamento e recursos. Os coordenadores dos institutos expressaram de modo pontual suas opiniões sobre o compartilhamento de recursos de modo pontual, conforme trechos das entrevistas online destacados e apresentados abaixo.

sem a rede, cada um ficaria fechado no seu laboratório e dessa forma nos comunicamos muito mais e fazemos trabalhos conjunto e aumentamos a produtividade de todos. Inclusive, sobretudo o acesso a equipamentos, nós usamos equipamentos que são dispendiosos, caros e a rede permite acesso a vários membros da rede;

[...] a colaboração, ela surge a partir do momento que você poe dinheiro, basicamente você tem que dar recursos. Eu não tenho o número de cabeça, mas foram centenas de viagens de pesquisadores e estudantes para fazer este tipo de 
coisa. E a terceira maneira de você colaborar é você criar... você ter equipamento multiusuário, está certo? Ao invés de você ter o mesmo equipamento em vários lugares diferentes, você tem um equipamento no centro, que faz parte do instituto e que é um equipamento multiusuário e que você disponibiliza recursos para que qualquer pessoa possa ir fazer uma viagem naquele instituto, o equipamento é do grupo como um todo;

[...] exatamente porque o Brasil é um país onde não se tem tantos recursos assim. Então nós temos que usar de forma otimizada os recursos;

Os depoimentos obidos corroboraram com o resultado de que o compartilhamento de recursos financeiros e o suporte a infraestrutura de pesquisa são os maiores benefícios obtidos com a realização das práticas colaborativas.

Os problemas e/ou obstáculos enfrentados durante o desempenho das práticas colaborativas foi o alvo do questionamento seguinte. Os pesquisadores sinalizaram em sua maioria, para o percentual de 60,4\%, para os recursos financeiros insuficientes e/ou cancelamento da manutenção do projeto pela agência de fomento. O Gráfico 15 pontuou o resultado obtido.

Gráfico 15 - Práticas Colaborativas - Problemas/obstáculos enfrentados

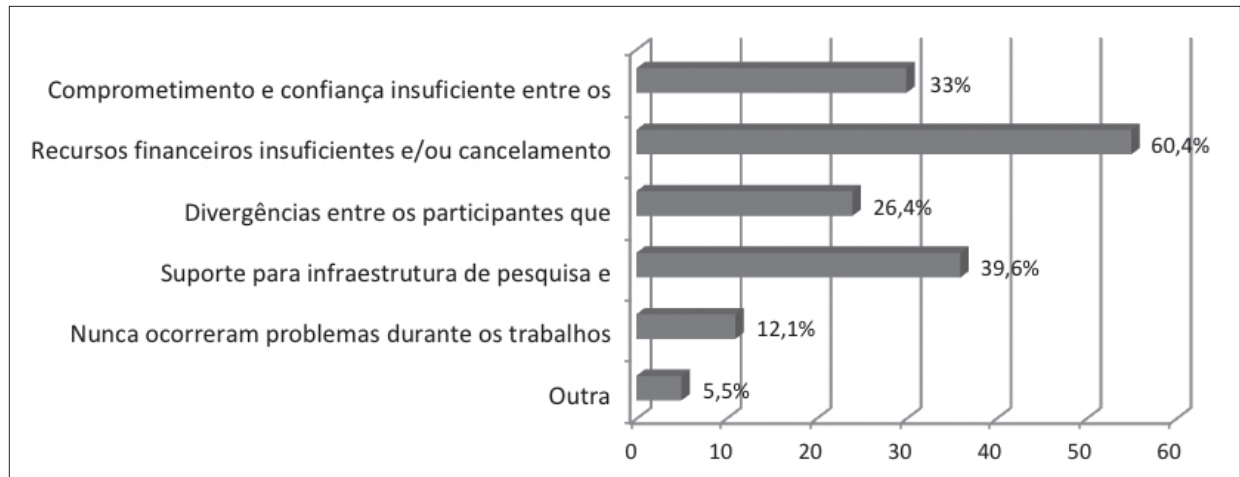

Fonte: Elaboração da autora.

Essa resposta que refletiu a expectativa e ansiedade dos pesquisadores e coordenadores dos INCTs durante a vigência do Programa, em alguns momentos da primeira fase, período contemplado nesta pesquisa. Um estado de espíri- 
to passível de ser captado durante os relatos colhidos nas entrevistas realizadas pela pesquisadora.

A demora ocasionada pelo repasse das verbas, a imprevisibilidade da continuidade do Programa INCT e o período que antecedeu a divulgação da Chamada INCT - MCTI/CNPQ/CAPES/FAPS No 16/2014 (CNPq, 2014a) prevista para sair a partir de 6 março de 2015 e somente divulgada em 11 de maio de 2016, caracterizaram muito bem o momento. $\mathrm{O}$ atraso de mais de um ano na divulgação do resultado provocou nos coordenadores dos INCTs a expectativa vivenciada durante o processo, conforme os trechos selecionados da entrevista online e apresentados logo a seguir.

[...] por exemplo o meu INCT em particular terminou no início desse ano, encerrou, e já encerrou com um pouco de atraso porque nós tivemos que fazer aditamento. Acabaram os recursos e ficamos esperando. A avaliação. do outro vai demorar $e$ então vamos ficar mais de um ano, um ano e meio sem ter os recursos. O que acontece em um ano e meio, as equipes se desarticulam e todo esse processo colaborativo vai por água abaixo. Ai depois você tem que investir e começar do zero. Esta bom que não seja do zero mas tem que recomeçar

com certeza compromete, nós estamos em uma fase onde já deveríamos estar com nova resposta do MCT, com novo projeto neste momento e então todas as decisões estão sendo todas prorrogadas, quer dizer postergadas. Então isso prejudica os INCTs, isso é bastante preocupante, essa demora nessa fase;

está muito atrasado, na verdade é preocupante, bastante preocupante porque essa resposta deveria ter saído em maio, foi adiado para outubro e agora foi adiado sem data definida. Estão falando em julho de 2016 e tal, mas isso signifique que não tem recurso em 2016, porque até ser realizada a chamada, assinar toda burocracia etc etc e o resultado sair, eu não conto com esse recurso antes do final de 2016. [...] Provavelmente vai ter um gap ai e mesmo que esse gap seja pequeno, ele é um gap importante porque as pessoas se desmobilizam. Na realidade eu já estou sentindo uma certa desmobilização dentro do INCT por falta de recursos. O recurso vai acabando, ai as pessoas não tem mais como se deslocar, não tem interesse.... obviamente sem recurso o interesse diminuiu, cada um vai buscar o seu e vira cada um por si e Deus por todos. Então é preocupante, muito preocupante;

[...] o edital era para ser julgado em 2015, mas já foi empurrado para 2016. Bom na verdade a comunidade científica está muito pessimista com relação ao que vai acontecer. Um programa importante como este deveria continuar, agora eu para The ser muito franco, tenho cá minhas dúvidas se realmente esse governo vai dar continuidade a este programa, no nivel do que foi o da primeira chamada; 
eu acho escandaloso, eu acho escandaloso cada vez que contam uma história diferente, um motivo pelo qual está sendo adiado [...] na realidade a mais de um ano que estão adiando, adiando e adiando e sabe Deus quando que de fato vai ter recursos.

Os relatos ilustraram que o problema/obstáculo predominante entre as práticas colaborativas é resultado da qualidade da gestão das agências de fomento, empreênciada às políticas púbicas, a qual compromete de modo acentuado a manutenção dessas práticas realizadas nos INCTs.

Um problema recorrente em projetos e políticas mantidos pelo governo e cercados por atrasos no repasse das verbas e falta de continuidade. A dependência financeira de fontes governamentais são as principais causas desse tipo de problema e registrou-se a preocupação com a desarticulação do grupo causada pelos atrasos no repasse dos recursos. Esse elemento compromete um trabalho realizado durante anos e favorece a perda de conquistas obtidas no desenvolvimento de práticas colaborativas.

Uma alternativa para minimizar essa situação foi justamente encontrada nas parcerias colaborativas que puderam ser realizadas fora da esfera governamental, entre os INCTs e os outros atores institucionais como empresas, organizações e instituições privadas. Essa alternativa funcionou como um recurso para minimizarem os problemas financeiros provenientes dos atrasos com o repasse de verbas para manutenção das pesquisas. A atividade foi identificada nas parcerias realizadas pelos institutos e sinalizada nos resultados coletados referentes às redes colaborativas para inovação.

Identificou-se um grande problema/obstáculo para a manutenção das práticas colaborativas e alternativas e sugestões para a solução e facilidades no processo de colaboração composeram a temática do questionamento seguinte, dirigido aos pesquisadores. O resultado obtido evidenciou a relação entre o problema/obstáculo indicado como prioritário, nos parágrafos anteriores e as sugestões para sua resolução. A solução indicada pela maioria dos respondentes indicada pela maioria dos respondentes para facilitar a colaboração foi a manutenção dos recursos financeiros e suporte à infraestrutura de pesquisa pelas agências de fomento, com $76,9 \%$ das indicações. 
Esse resultado enfatizou a grande preocupação dos pesquisadores da área em relação à manutenção dos recursos financeiros por parte das agências de fomento, os quais enfrentam cotidianamente os problemas derivados da gestão realizada. A infraestrutura de pesquisa compatível com o avanço tecnológico obteve $68,1 \%$ de indicações, a refletir que os pesquisadores da área querem ter a sua disposição os recursos tecnológicos mais atualizados para o desempenho de suas práticas, apesar de a utilização das tecnologias não ser realizada de modo pleno. O Gráfico 16 apresentou o resultado obtido.

Gráfico 16 - Sugestões para facilitar a colaboração

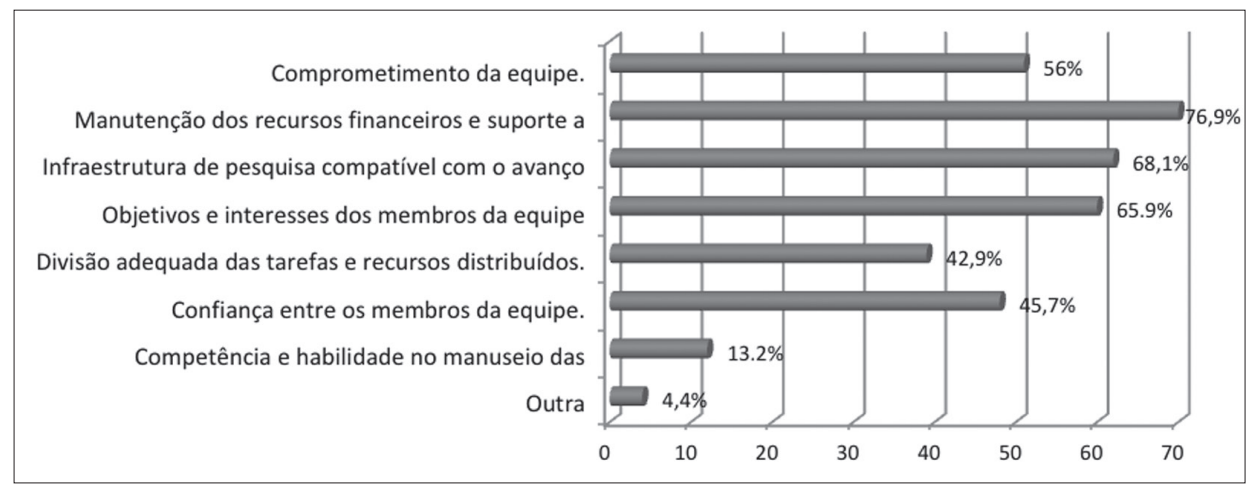

Fonte: Elaboração da autora.

Os objetivos e interesses alinhados, confiança entre os membros da equipe e divisão adequada das tarefas e recursos distribuídos corresponderam a sugestões cujos percentuais indicram preocupação com o ambiente no qual ocorrem as práticas colaborativas.

A internacionalização das práticas colaborativas foi a faceta da colaboração que permeou o questionamento realizado na sequência, esteve presente na análise da produção científica e foi o indicador contemplado nos resultados apresentados. Registrou-se o percentual de $78 \%$, para a afirmativa em relação à realização de práticas colaborativas no exterior, coerente com o número de trabalhos publicados na mesma abrangência geográfica e identificados na análise da produção científica neste capítulo. 
A área das ciências exatas, identificada no perfil dos pesquisadores como a predominante nos INCTs, são consideradas como "áreas onde a colaboração científica com parceiros internacionais é um mecanismo de redução de custos, uma vez que a implantação de alguns equipamentos e técnicas pode custar muito à agência local." (LETA; CRUZ, 2003, p. 154).

A identificação da internacionalização das práticas colaborativas dos pesquisadores dos institutos foi um resultado positivo, considerando-se os objetivos pretendidos pelo Programa INCTs, de impulsionar a pesquisa científica básica e fundamental e torná-la competitiva internacionalmente. O resultado visualizado no Gráfico 17 confirmou a prevalência dessa prática na esfera internacional.

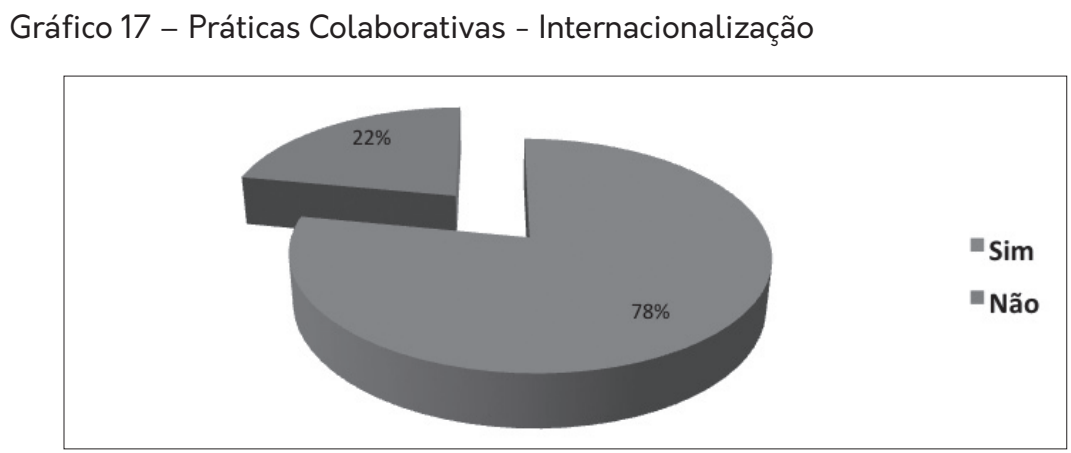

Fonte: Elaboração da autora.

A apresentação dos resultados e discussão sobre a percepção acerca da colaboração e suas práticas continuou nos parágrafos seguintes desta seção. A área da Nanotecnologia caracteriza-se como um domínio multidisciplinar coberto por pesquisadores dos mais diversos campos do conhecimento. Esses contribuem com suas expertises em prol do desenvolvimento de aplicações as mais variadas e convertidas em benefícios para a sociedade. Os INCTs de Nanotecnologia não fugiram a essa regra, conforme ficou comprovado na identificação do perfil dos pesquisadores dos institutos.

As redes de práticas colaborativas para inovação forneceram a formação mais adequada para o tipo de relacionamento ensejado no domínio da Nanotecnologia. Escalante Ludeña (2008, p. 17) ressalta ainda que "como a nanotecnologia envolve muitas áreas do conhecimento, para ser desenvolvida precisa de 
um trabalho multidisciplinar onde interajam muitos atores com suas diversas competências, surgindo assim à necessidade de redes de inovação.” Os resultados pertinentes à inovação associados às práticas colaborativas realizadas pelos INCTs são destacados na sequência.

As etapas da cadeia de inovação onde os institutos atuaram, no período de 2008 a 2014, primeira edição do Programa INCTs, foram sintetizadas e dispostas no Quadro 9. O NANOBIOTECNOLOGIA foi o instituto que indicou contemplar todas as fases da cadeia, ao assinalar as opções apresentadas no relatório de acompanhamento de projeto. Foram marcadas as opções desde a geração de conhecimento com potencial aplicação tecnológica até opção outra indicada como prestação de serviço para a indústria. O DISSE e o NANOCARBONO atuaram em três etapas e o NAMITEC em apenas uma conforme pode ser confirmado no Quadro 9.

Quadro 9 - Cadeia de inovação dos INCTs

\begin{tabular}{|l|c|c|c|c|}
\hline \multirow{2}{*}{ CADEIA DE INOVAÇÃO } & \multicolumn{3}{c|}{ INCT } \\
\cline { 2 - 5 } & DISSE & NAMITEC & NANOBIOTECNOLOGIA & NANOCARBONO \\
\hline $\begin{array}{l}\text { Geração de conhecimentos com } \\
\text { potencial aplicação tecnológica }\end{array}$ & $\times$ & $\times$ & $\times$ & $\times$ \\
\hline Prova de Conceito & $\times$ & $\times$ & $\times$ & $\times$ \\
\hline Projeto Piloto & $\times$ & & $\times$ & $\times$ \\
\hline Escalonamento além da bancada & & & $x$ & \\
\hline $\begin{array}{l}\text { Desenvolvimento final de processo } \\
\text { ou produto }\end{array}$ & & & $x$ & \\
\hline Outra & & & $x^{1}$ & \\
\hline
\end{tabular}

Fonte: Elaboração da autora.

O NANOBIOTECNOLOGIA pontuou como inovações, os projetos desenvolvidos pelo instituto que envolviam a síntese, caracterização e aplicações biológicas (testes em animais de laboratório) de materiais nanoestruturados voltados para a saúde humana, animal e biorremediação. O processo evoluiu e passou por incorporações diversas, dos testes que passaram a ser clínicos, tanto para humanos quanto para animais, como a inclusão de médicos e veterinários.

1 ONANOBIOTECNOLOGIA indicou como outra opção a prestação de serviço para a indústria. 
Esse foi um aparato suficiente para produzir prova de conceito. A necessidade de realizar testes clínicos, fase 1 e fase 2, resultou em associações com hospitais, centros de tratamento e empresas. Compuseram-se parcerias colaborativas em prol da inovação e desenvolvimento de produtos que trouxeram retorno para os vários segmentos da sociedade.

O DISSE pontuou como inovação iniciativas como: a geração de conhecimento para produção de fotodetectores de infravermelho com detectividade otimizada, operação de temperaturas mais elevadas e maior seletividade; atuação na área de células solares com a investigação em nanoestruturas semicondutoras que pudessem baratear esses dispositivos; desenvolvimento de um sistema de detecção de infravermelho para monitorar a presença de $\mathrm{CO}^{2}$, cujo conceito foi demonstrado; desenvolvimento de um equipamento fruto de um projeto piloto, em fase final ; desenvolvimento, dentro do INCT, de um chip de silício para a leitura de sinais de fotodetectores de infravermelho foi desenvolvido e alvo de ampla repercussão na mídia nacional conforme divulgado no CNPq (2013b).

Dentre as ações inovadoras do DISSE identificou-se ainda o desenvolvimento de matrizes biodimensionais e lineares de sensores de infravermelho, utilizando-se sensores do tipo QWIP e fotodiodos de InGaAs. Além dessa, a associação pela primeira vez, de vários grupos de laboratórios brasileiros em trabalho cooperativo em prol do desenvolvimento de fotodetectores de radiação infravermelha para comercialização futura.

O NANOCARBONO sinalizou como frentes de inovação o trabalho desenvolvido em prol da construção de um Centro de Tecnologia de nanotubos, além do escalonamento e produção de compósitos de cimento com nanotubos, em colaboração com a empresa InterCement do grupo Camargo Correa. Também de compósitos com poliuretano e epóxis, em atenção à demanda da Petrobrás, para o desenvolvimento de novos materiais com propriedades superiores para a extração de petróleo do pré-sal.

O NAMITEC indicou como contribuições inovadoras o desenvolvimento de dispositivos, circuitos integrados e redes de sensores sem fio com alto potencial de aplicação tecnológica, além dos trabalhos que incluem prova de conceito desenvolvidos no Instituto.

A discussão e apresentação dos resultados sobre as redes de práticas colaborativas para inovação foi um desmembramento do segundo objetivo da pes- 
quisa. Aproveitou-se a incursão realizada no âmbito das cadeias de inovação e realizou-se um parênteses para inserir a rede da cadeia de inovação construída baseada nas relações indicadas no Quadro 9.

O grafo que representou a rede da cadeia de inovação foi apresentado na Figura 9, e possibilitou a visualização do desenho das conexões diagnosticadas no contexto da rede.

Figura 9 - Grafo da Rede Cadeia de Inovação dos INCTs

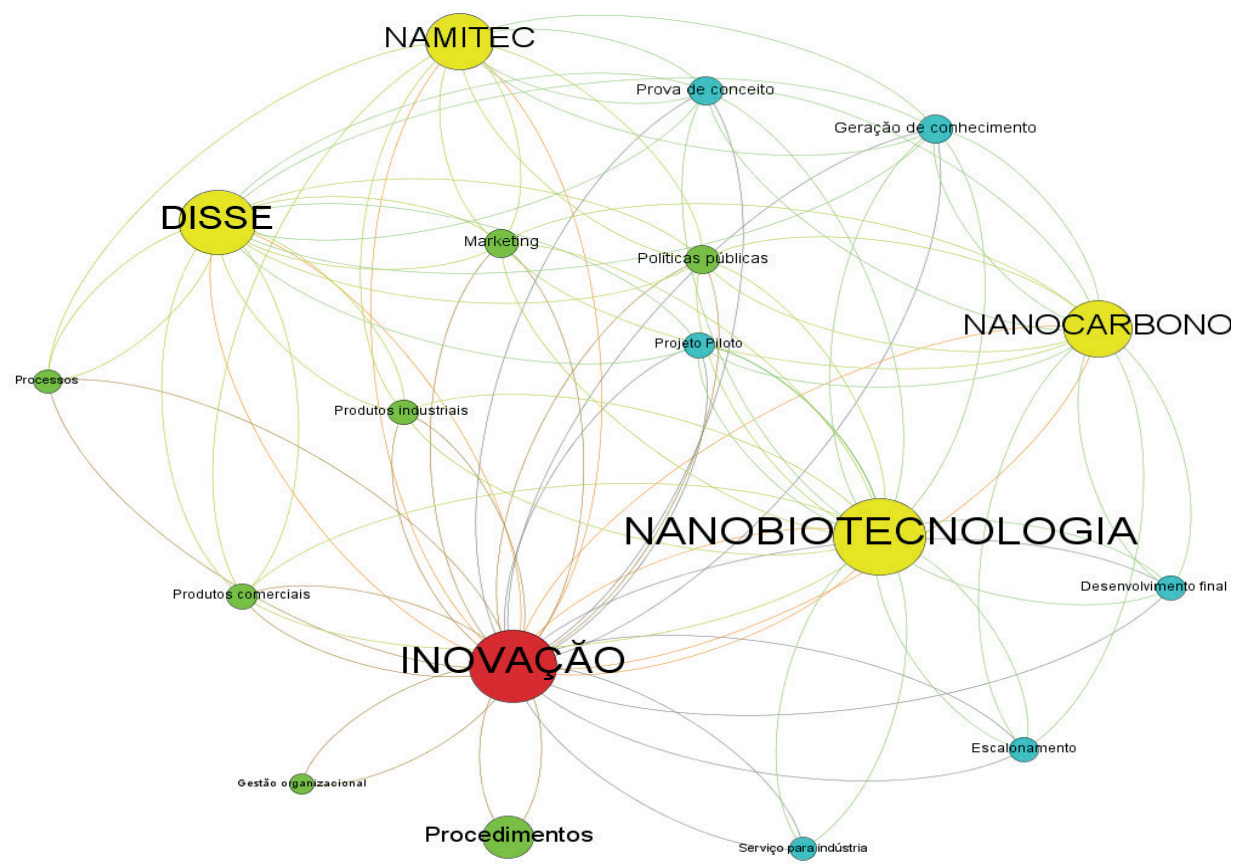

Fonte: Elaboração da autora.

Identificaram-se, no grafo visualizado, 18 nós e 94 arestas. Para visualização, utilizou-se o algoritmo de distribuição do software livre Gephi, Fruchterman-Reingol. A distribuição por cores foi realizada de acordo com os atributos de natureza da rede assim denominados como: cadeia inovadora, tipo, etapa e INCT, os quais foram utilizados apenas para a composição e caracterização da rede porque o foco central foram as interações compreendidas no contexto. 
A caracterização realizada permitiu uma plena visualização dos nós da rede e suas conexões. Em vermelho, identificou-se o nó que representou a inovação, o qual possuía o maior número de arestas interligadas. Sua importância na rede foi identificada de acordo com seu grau médio, um peso de 34, o maior de toda rede e com o maior número de conexões. Em amarelo foram identificados os INCTs: o NANOBIOTECNOLOGIA apareceu em maior destaque, apresentou o maior número de conexões entre os institutos e refletiu as etapas da cadeia de inovação por ele contempladas.

Em azul identificaram-se as etapas da inovação e os tipos, em vermelho. O grafo apresentado permitiu uma visualização distinta da rede e das conexões existentes e não se identificou a criação de clusters volumosos. Infere-se que esta configuração reflita o número de nós dispostos na rede, se um detalhamento maior dos elementos que compõem a cadeia de inovação fosse contemplado, os grupos poderiam evidenciar-se.

Entretanto, como a formação da rede contemplou as informações exclusivas dos relatórios de projeto, este detalhamento não foi possível. Observaram-se apenas as agregações e conexões, de acordo com as iniciativas e práticas que os INCTs contemplaram em seu foco inovador. As métricas gerais da rede foram apresentadas no Quadro 10.

Quadro 10 - Métricas da Rede Cadeia de Inovação

\begin{tabular}{|c|c|}
\hline \multicolumn{2}{|c|}{ REDE CADEIA DE INOVAÇÃO } \\
\hline Métrica & Valores \\
\hline Grau médio & 5,222 \\
\hline Diâmetro da rede & 2 \\
\hline Densidade do grafo & 0,307 \\
\hline Modularidade & 0,086 \\
\hline Componentes conectados & 18 \\
\hline Coeficiente de claustering médio dos nós & 0,401 \\
\hline Cumprimento médio e caminho das arestas & 1,693 \\
\hline
\end{tabular}

Fonte: Elaboração da autora.

As práticas colaborativas podem ser mensuradas de formas distintas. A mais recorrente na comunidade científica realiza-se por meio das colaborações cientí- 
ficas, especialmente com a mensuração das coautorias das produções. No âmbito das práticas realizadas entre as universidades, empresas e institutos de ciência e tecnologia, as interações/integrações também podem ser utilizadas como parâmetro de mensuração, sejam essas no escopo de capacitações, eventos ou construção de artefatos para difusão do conhecimento. Esses resultados puderam ser contabilizados por intermédio dos dados coletados nos relatórios de acompanhamento de projeto.

Os institutos da área de Nanotecnologia registraram um índice elevado de atividades cuja proposta era promover a transferência de conhecimento para a sociedade, em especial ações que contemplavam a divulgação e/ou difusão científica. Elas contemplaram os mais diversos segmentos da sociedade como: o público em geral; profissionais da área; estudantes em todos os níveis de formação e pesquisadores dos INCTs. O Quadro 11 relacionou as atividades contempladas em cada INCT e identificadas nos relatórios.

Quadro 11 - Difusão científica - Práticas

\begin{tabular}{|c|l|}
\hline \multicolumn{2}{|c|}{ PRÁTICAS PARA DIFUSÃo CIENTífICA } \\
\hline INCT & \multicolumn{1}{|c|}{ ATIVIDADES/PRODUTOS } \\
\hline DISSE & $\begin{array}{l}\text { artigo em jornais e revistas, blog, conferência, entrevistas, feiras, fôlders, } \\
\text { Kit: ver o invisível para distribuição em museus e centros de ciência, livreto, } \\
\text { minicursos, notícias na mídia aberta, páginas da Web (site do INCT), painel/ } \\
\text { pôster, palestras, programa de TV, seminário, simpósio, vídeo, visitas a } \\
\text { laboratórios, canal youtube. }\end{array}$ \\
\hline NAMITEC & $\begin{array}{l}\text { boletim informativo, boletim técnico, colóquio, curso de curta duração com } \\
\text { oficina, curso ministrado em eventos, feiras, fôlders, notícias na mídia aberta, } \\
\text { páginas da web (site do INCT), palestras, premiações, programa de rádio, } \\
\text { workshop INCT. }\end{array}$ \\
\hline NANOBIOTECNOLOGIA & $\begin{array}{l}\text { entrevistas, exposição, feiras, jornal (entrevista, notícias), minicursos, palestras, } \\
\text { programa de TV, vídeo "Nanotecnologia: o que é isso?", minilaboratório } \\
\text { portátil para o ensino de química, visita a escolas públicas. }\end{array}$ \\
\hline NANOCARBONO & $\begin{array}{l}\text { artigo em jornais e revistas, colóquio, canal Youtube, curso para pós- } \\
\text { graduação, curso de curta duração, curso de verão, curso online (modalidade } \\
\text { a distância), entrevistas, esculturas, formação de professores em nanociências, } \\
\text { livro, material didático na internet, mesa redonda, minicursos, oficinas, páginas } \\
\text { da web (site do INCT), painel/pôster, palestras, participação em congresso de } \\
\text { ensino ou difusão científica, programa de TV, prospecto, seminário (dobrado), } \\
\text { vídeo, visita a escolas públicas. }\end{array}$ \\
\hline
\end{tabular}

Fonte: Elaboração da autora. 
Identificou-se a preocupação dos institutos em cumprir a missão do Programa INCT, no que se refere à transferência de conhecimento para a sociedade. As atividades implementadas e os produtos distribuídos pelos INCTs foram comprovantes do sucesso dessa frente de atuação em total sintonia com a missão do programa, conforme confirma-se a seguir:

Transferência de conhecimento para a sociedade, utilizando outros instrumentos além da publicação científica. O centro deve ter um programa ambicioso de educação em ciência e difusão de conhecimento, conduzido por seus pesquisadores e pelos bolsistas a ele vinculado, focalizado no fortalecimento do ensino médio e na educação científica da população em geral (PROGRAMA, 2008, p. 5, grifo do autor).

Os INCTs contemplaram distintas modalidades de cursos e atividades voltadas para a difusão científica, além de terem desenvolvido produtos para distribuição com o público alvo. Em termos quantitativos, estes dados representaram o total de 829 atividades/produtos. Os resultados apresentados refletiram a forte atuação do NAMITEC nas atividades voltadas para a difusão científica. Os percentuais apresentados pelos institutos estão destacados no Gráfico 18.

Gráfico 18 - Difusão Científica - Atividades/Produtos

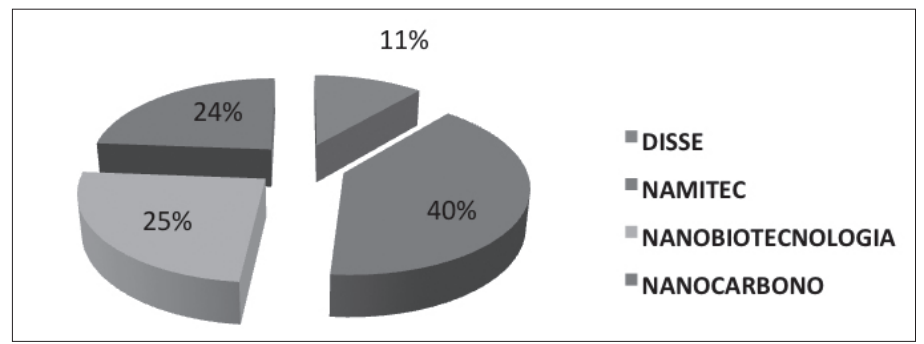

Fonte: Elaboração da autora.

O depoimento de um dos coordenadores do INCT analisado registrou a relevância da atuação do instituto nos cursos realizados. A inserção desses cursos pelo instituto alcançou o Brasil e a América Latina, incidência da internacionalização no âmbito da difusão científica. 
Outra ação do INCT foi fazer cursos a distância. Então essa foi uma iniciativa muito importante também onde nós oferecemos cursos a distância e aberto primeiro ao Brasil, a pessoas leigas e deu muito sucesso e depois até abrimos para a América Latina também e fez muito sucesso.

Dentre as atividades que identificaram as práticas colaborativas para inovação destacaram-se as ações voltadas para a formação de recursos humanos, as quais foram discriminadas como disciplinas ministradas; cursos de pós-graduação stricto senso criados; eventos organizados e parcerias entre os institutos e o estado na área de educação. A Tabela 3 apresentou o resultado a seguir.

Tabela 3 - Ações para formação de recursos humanos

\begin{tabular}{c|c|c|c|c|c}
\hline \multirow{2}{*}{ INCT } & \multicolumn{3}{|c|}{ AÇÕES PARA FORMAÇÃO DE RECURSOS HUMANOS } & \multirow{2}{*}{ Total } \\
\cline { 2 - 5 } & Disciplinas & $\begin{array}{c}\text { Cursos de Pós-Graduação } \\
\text { Stricto Senso }\end{array}$ & Eventos & $\begin{array}{c}\text { Parcerias / Estado } \\
\text {-Educação }\end{array}$ & 29 \\
\hline DISSE & 18 & 2 & 9 & 0 & 37 \\
\hline NAMITEC & 0 & 3 & 4 & 3 & 21 \\
\hline NANOBIOTECNOLOGIA & 14 & 1 & 10 & 1 & 23 \\
\hline Total & 12 & 0 & 54 & 6 & 110 \\
\hline
\end{tabular}

Fonte: Elaboração da autora.

O NAMITEC confirmou sua acentuada atuação nas ações referentes à formação de recursos humanos, um ganho sintonizado com seus objetivos. Levando-se em consideração, a composição da rede de pesquisadores que atuam no instituto e a reunião de fatores que influenciaram o resultado obtido, esse era esperado. Esse instituto apresentou o maior número de pesquisadores vinculados à sua rede de colaboração. A sede estar situada na região sudeste do país caracterizou posição privilegiada, levando-se em consideração as oportunidades e fontes para financiamentos existentes, além de possuir grande número de instituições associadas. Esses elementos favoráveis para a realização de articulações e parcerias se refletiram nos quantitativos computados e o deixou quase sempre em vantagem em relação aos outros INCTs investigados.

As ações para a formação de recursos humanos ressaltaram a atuação do NAMITEC. Entretanto, a prática efetiva foi realizada por todos os outros INCTs 
analisados, um resultado pontuado na indicação da prática colaborativa mais recorrente e também quantificado e apresentado ao longo desta seção.

Destacaram-se os eventos organizados pelos institutos das ações acima contempladas e realizada a quantificação no âmbito regional, nacional e internacional. Os eventos organizados pelos INCTs foram identificados também nos resultados referentes à produção científica. Essa produção foi significativa e apresentou, além de artigos de periódicos, trabalhos publicados em anais nos diversos eventos, dentre eles os que foram organizados pelos institutos na área de Nanotecnologia. A Tabela 4, resgatou o quantitativo dos eventos organizados.

Tabela 4 - Eventos organizados pelos INCTs

\begin{tabular}{l|c|c|c|c}
\hline \multirow{2}{*}{ INCT } & \multicolumn{3}{|c|}{ EVENTOS ORGANIZADOS } & \multirow{2}{*}{ TOTAL } \\
\cline { 2 - 5 } & REGIONAL & NACIONAL & INTERNACIONAL & 9 \\
\hline DISSE & 3 & 5 & 1 & 31 \\
\hline NAMITEC & 12 & 4 & 15 & 6 \\
\hline NANOBIOTECNOLOGIA & 2 & 0 & 4 & 10 \\
\hline NANOCARBONO & 0 & 7 & 3 & 56 \\
\hline TOTAL & 17 & 16 & 23 & \multirow{2}{*}{} \\
\hline
\end{tabular}

Fonte: Elaboração da autora.

O conjunto de práticas colaborativas identificadas indicou alguns indícios da interferência dessas ações na produção científica dos pesquisadores dos INCTs. As interações/integrações, as inovações e os eventos realizados favoreceram a produção científica e resultou em novos insumos coroando o processo. O depoimento de um dos coordenadores dos INCTs ilustra a relevância dos eventos presenciais realizados e a efetiva participação dos pesquisadores e alunos da área.

[...] na interação a coisa mais importante são as reuniões presenciais, são os encontros anuais. Nesses encontros anuais todo mundo se conhece porque você tem um ambiente, têm as reuniões, as sessões de pôsteres, você tem todos os estudantes, as pessoas tem a oportunidade de se conhecer pessoalmente, trocar ideias, um vê o pôster..., um aluno vê o pôster do outro. Então em minha opinião, em termos de colaboração dentro do âmbito do INCT eu senti que foi mais efetivo o encontro presencial, nos encontros anuais surgiram muitas colaborações, mais do que nessas ferramentas, nesses sites. 
Quanto mais práticas colaborativas ocorrerem e eventos forem organizados pelos institutos, maiores as possibilidades de produção e apresentação de resultados por seus pesquisadores. No que se refere à produção científica, os resultados apontam positivamente.

Os institutos estavam tão imbuídos dos seus propósitos e em consonância com as recomendações estabelecidas pelo Programa INCTs que recomendavam ações frequentes para a difusão científica. A programação de novas ações para apresentar os resultados de suas práticas científicas expressa essa convicção. Este planejamento foi alvo do escrutínio da autora, que os congregou no Quadro 12.

Quadro 12 - Difusão científica - Planejamento de ações

\begin{tabular}{|c|c|c|c|c|c|}
\hline \multirow{2}{*}{$\begin{array}{l}\text { DIFUSÃO CIENTÍFICA - } \\
\text { PLANEJAMENTO DE AÇÕES }\end{array}$} & \multicolumn{4}{|c|}{ INCT } & \multirow{2}{*}{ Total } \\
\hline & DISSE & NAMITEC & NANOBIOTECNOLOGIA & NANOCARBONO & \\
\hline Artigos de divulgação científica & 1 & & & & 1 \\
\hline Boletim Informativo & & 6 & & & 6 \\
\hline Blog & 1 & & & & 1 \\
\hline Colóquio & & 2 & & & 2 \\
\hline Congresso & & 3 & & & 3 \\
\hline Cursos de curta duração & & 3 & & & 3 \\
\hline Disciplinas de pós-graduação & & & 1 & & \\
\hline Encontro internacional & & & 1 & & 1 \\
\hline Elaboração de site & & 1 & & & 1 \\
\hline Kit: ver o invisível & 1 & & & & 1 \\
\hline Livro & & & 1 & & 1 \\
\hline Mini Laboratório Portátil & & & 1 & & 1 \\
\hline Museu virtual de nanotecnologia & 1 & & & & 1 \\
\hline Oficinas & & 1 & & & 1 \\
\hline Palestra & & 1 & 3 & & 4 \\
\hline Participação em feiras & 1 & & & & 1 \\
\hline Programa de rádio & & & & 1 & 1 \\
\hline Programa de TV & & & & 1 & 1 \\
\hline Vídeo & 1 & & 2 & 1 & 4 \\
\hline Workshop INCT & & 1 & & & 1 \\
\hline TOTAL & 6 & 18 & 9 & 3 & 36 \\
\hline
\end{tabular}

Fonte: Elaboração da autora. 
Esse planejamento ilustrou o desejo de fortalecer as ações realizadas até então e abrir novas frentes para a difusão da Ciência, e como consequência promover o reconhecimento e também a divulgação da área de Nanotecnologia, tão importante para a sociedade em diversos aspectos e frentes de aplicações, mas ainda pouco conhecida pela maioria da população.

Nanotecnologia, é uma área do conhecimento que causa muita curiosidade e expectativa, especialmente para a parcela da sociedade na qual o tema é pouco difundido. Esse mundo desconhecido e cheio de mistérios pouco a pouco vem sendo desmistificado. Ações como as que foram contempladas pelos INCTs contribuem significativamente para diminuir o espaço entre a sociedade e a Nanotecnologia. A preocupação desses institutos em reverter a situação presente é evidente e está registrada no planejamento realizado e na intenção de levar para a população melhor compreensão sobre a área.

Os resultados obtidos nos INCTs referentes à formação de recursos humanos não se encerraram. Destacaram-se ainda os achados concernentes à formação em segmentos da academia os quais contemplam desde a base até os mais altos degraus de titulação. A apresentação desses resultados evidenciou a correlação entre as práticas colaborativas desenvolvidas e os objetivos do Programa INCTs, no que se refere à formação de pesquisadores contemplados na iniciação científica, mestrado, doutorado e estágio pós-doutoral. A missão dos INCTs é clara quando destaca sua pretensão no item referente à formação de recursos humanos, conforme se destaca:

Formação de Recursos Humanos. O Instituto deve promover a formação de pessoal qualificado, por meio de cursos de pós-graduação e por meio de envolvimento de estudantes de graduação. Para aqueles IN's voltados a aplicações, tecnologia e relações com empresas, espera-se, além da formação de cientistas acadêmicos de nível internacional, que haja treinamento em ambiente empresarial, cursos de curta e longa duração, treinamento de técnicos especializados, entre outros. Para IN's voltados à ciência básica e fundamental espera-se a formação de cientistas com inserção internacional e com impacto na criação de ciência e em sua difusão (PROGRAMA..., 2008, p. 5, grifo do autor). 
A quantificação do resultado referente à formação de recursos humanos foi positiva. Foram formados 1.017 alunos nos diversos níveis de atuação acadêmica. Os INCTs que apresentaram os maiores percentuais de formação em recursos humanos foram o NAMITEC (38\%) e o NANOBIOTECNOLOGIA (37\%), resultados sintonizados com os dados apresentado nos parágrafos anteriores. O Gráfico 19 detalhou a quantificação obtida pelos institutos.

Gráfico 19 - Formação de recursos humanos

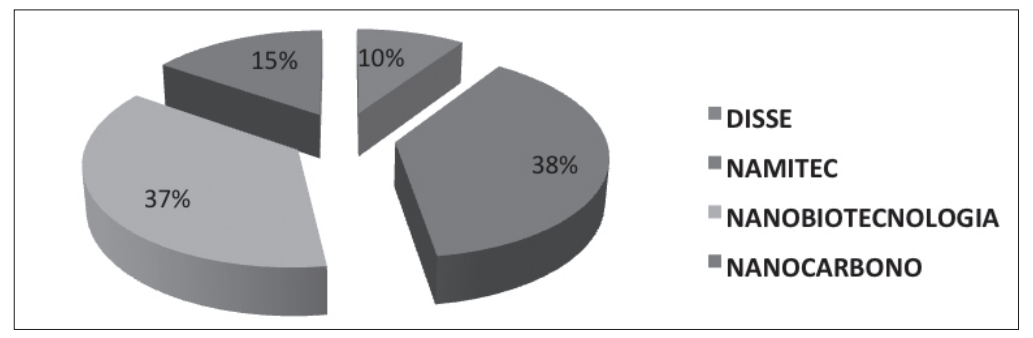

Fonte: Elaboração da autora.

Os níveis contemplados foram: iniciação científica, mestrado, doutorado e estágio pós-doutoral. A formação da base científica foi a maior preocupação do NANOBIOTECNOLOGIA e esse instituto registrou o total de 191 alunos de iniciação científica em suas atividades. Contudo, o NAMITEC, instituto com ações diversas nessa frente de atuação, não registrou nenhum alunos neste nível de formação. O DISSE e o NANOCARBONO, com 50 e 28 alunos respectivamente, registraram discreta atuação neste nível. Entretanto, a formação no doutorado foi a que contemplou o maior número de registros, o total de 395 alunos, dados satisfatórios e indicativos do sucesso na atuação dos INCTs, ressalvadas as proporções e dificuldades peculiares de cada instituto. O Gráfico 20 ressaltou as informações pontuadas. 
Gráfico 20 - Níveis de formação dos recursos humanos

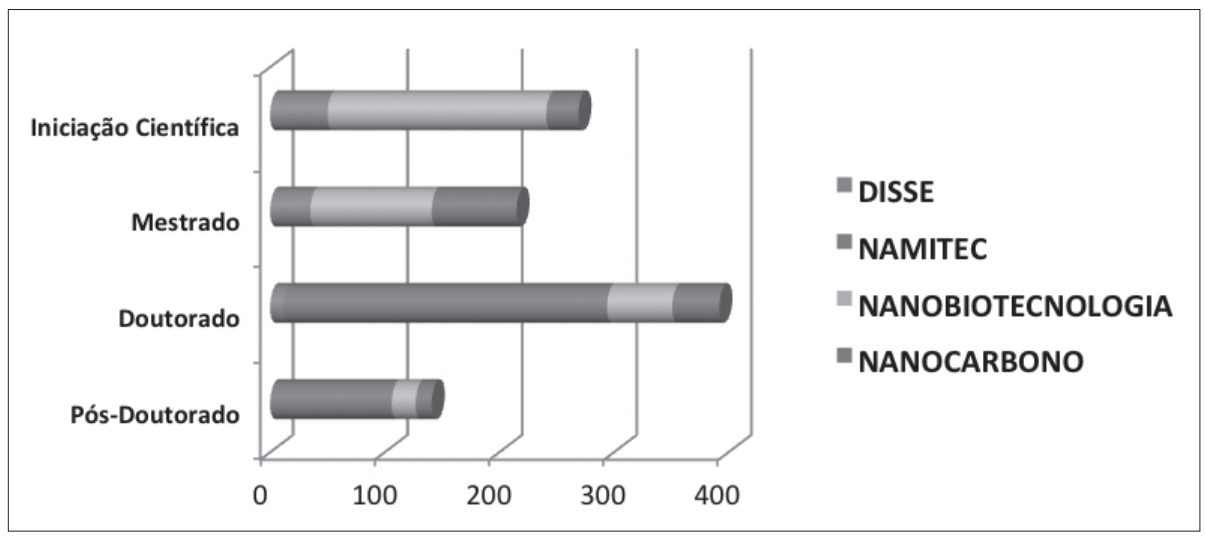

Fonte: Elaboração da autora.

Os resultados da formação de recursos humanos foram insumos representados pela produção científica e estavam alinhados com mais uma missão do Programa INCT no que se refere ao desenvolvimento de pesquisas, conforme se destacou a seguir:

Pesquisa. Promoção de pesquisa de vanguarda e elevada qualidade, de padrão competitivo internacionalmente na área de conhecimento. O centro deve ser estruturado e funcionar como uma referência de excelência nacional na sua área de atuação, de modo a contribuir efetivamente para o desenvolvimento nacional segundo as metas definidas no Plano Nacional de Ciência, Tecnologia e Inovação para o Desenvolvimento Nacional (PROGRAMA..., 2008, p. 5, grifo do autor).

O extrato da produção científica analisado evidenciou a sintonia existente entre a formação e o produto, uma evidência dos esforços desprendidos pelos INCTs para cumprir o que foi solicitado no edital do Programa INCTs, como destacado. O Gráfico 21 permitiu a visualização dos dados obtidos. 
Gráfico 21 - Formação de recursos humanos - Produção científica

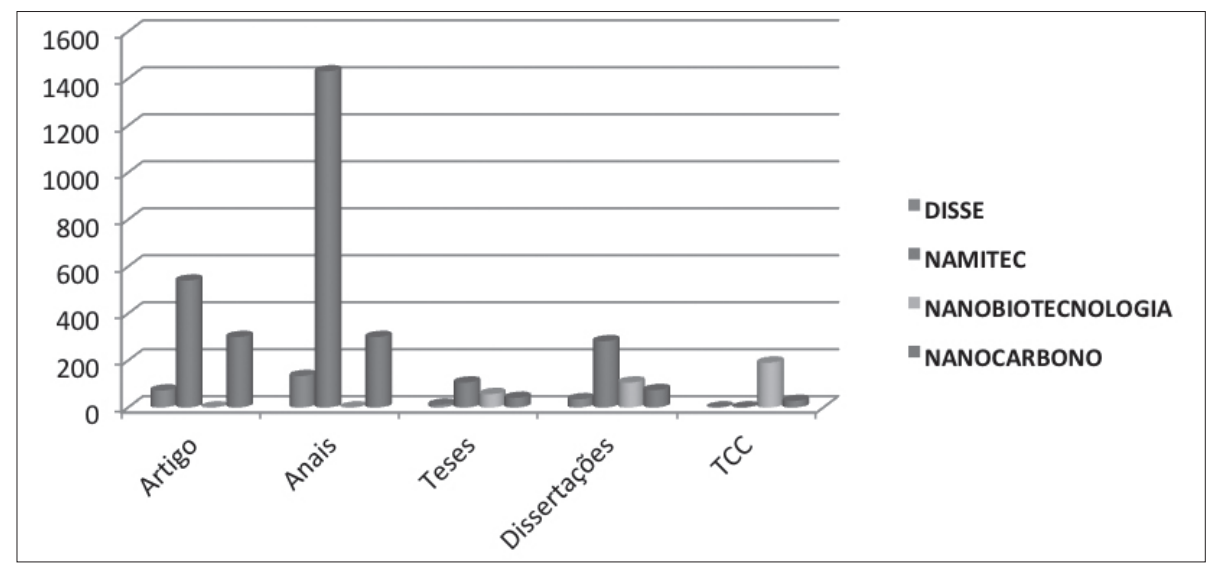

Fonte: Elaboração da autora.

O Gráfico 21, sinalizou para um resultado obtido com base nas informações retiradas dos relatórios de acompanhamento de projeto dos coordenadores dos INCTs investigados. Desse modo, faz-se necessário registrar que o NANOBIOTECNOLOGIA não indicou a produção científica em artigos e anais, no relatório existia a informação de que este dado seria enviado posteriormente. O NANOCARBONO forneceu a informação, de modo impreciso para os anais. Estava indicado "mais de 300", utilizou-se como base para a quantificação o número 300.

\section{Redes de práticas colaborativas para inovação}

Os resultados provenientes dos dados coletados nos relatórios de acompanhamento de projeto dos INCTs da área de Nanotecnologia forneceram os subsídios necessários para a identificação das redes colaborativas existentes nos institutos. A incursão que foi realizada nos relatórios permitiu a identificação não apenas das redes de práticas colaborativas. Conforme sinalizou Latour (2012) as diversas formações de grupos e alistamentos em grupos contraditórios puderam ser percebidas.

Algumas das redes identificadas foram: a rede de colaboração dos pesquisadores dos INCTs da área de Nanotecnologia, no âmbito da produção científica; a rede das práticas colaborativas, no âmbito das interações entre os INCTs e os atores que a compuseram; a rede dos INCTs e artefatos pertinentes à infraestrutura e-Science; a rede da cadeia de inovação; a rede dos INCTs e políticas públicas que 
sustentaram o Programa e seu entorno; a rede das universidades; das instituições; das organizações; dos agentes de fomento; das empresas; dos laboratórios; dos hospitais, e muitas outras pontuadas no conglomerado investigado.

As exigências encerradas no segundo objetivo específico da pesquisa. A identificação das práticas e redes colaborativas efetivas dos pesquisadores foram contempladas. Os resultados obtidos nesta etapa da pesquisa foram satisfatórios. Uma seleção das redes identificadas foi realizada para manter o foco no objetivo proposto. Contemplou-se desse modo, na análise realizada, a rede de práticas colaborativas para inovação dos INCTs da área de Nanotecnologia.

A Análise de Redes Sociais, um dos métodos utilizados nesta pesquisa, foi o parâmetro para definir e interpretar a rede identificada e a representação por grafos permitiu a visualização dos laços característicos da rede. As interações entre os atores/actantes identificados, ou na linguagem da ARS, dos nós conectados, as posições assumidas e os elos existentes foram pontos contemplados com as métricas pertinentes aplicadas.

As métricas utilizadas para obtenção de uma visão geral da rede foram baseadas nos parâmetros fornecidos pelo software livre Gephi, versão beta 0.8.02, descritas por (MARQUEZ, 2013) por ele denominadas como estatísticas:

- grau médio para indicar o peso dos nós de acordo com a quantidade de suas conexões na entrada e saída;

- diâmetro da rede calculando-se a distância média do grafo entre os pares de nós. As medidas de centralidade de intermediação, proximidade e excentricidade foram contempladas;

- densidade do grafo para identificar quanto faltava para a rede estar completa;

- modularidade para definir os clusters de acordo com a força de suas conexões e detectar as comunidades existentes.

A visão geral dos nós pode ser obtida com os valores do coeficiente de clustering médio e o das arestas com o cumprimento médio de caminho.

A rede das práticas colaborativas para inovação dos INCTs da área de Nanotecnologia foi identificada e apresentou 248 nós e 1.196 arestas. Os atributos utilizados na caracterização da rede contemplaram: estrutura; dimensão jurídica; alcance geográfico, tipo de interação, e o ambiente onde ocorreram as práticas. 
Para uma visualização o mais limpa possível, utilizou-se o algoritmo de distribuição do software livre Gephi, Fruchterman-Reingol. As cores características dos atores/actantes apresentados foram definidas tomando-se por base a estrutura identificada na rede. As universidades foram representadas pela cor vermelha; as empresas pelo azul-marinho; os laboratórios pelo verde claro; as instituições pelo azul; os INCTs pelo amarelo; as políticas pelo laranja; as organizações pelo vinho; os agentes de fomento pelo lilás; e os hospitais pelo verde escuro. A Figura 10 apresentou a rede identificada.

Figura 10 - Grafo da Rede de Práticas Colaborativas para Inovação

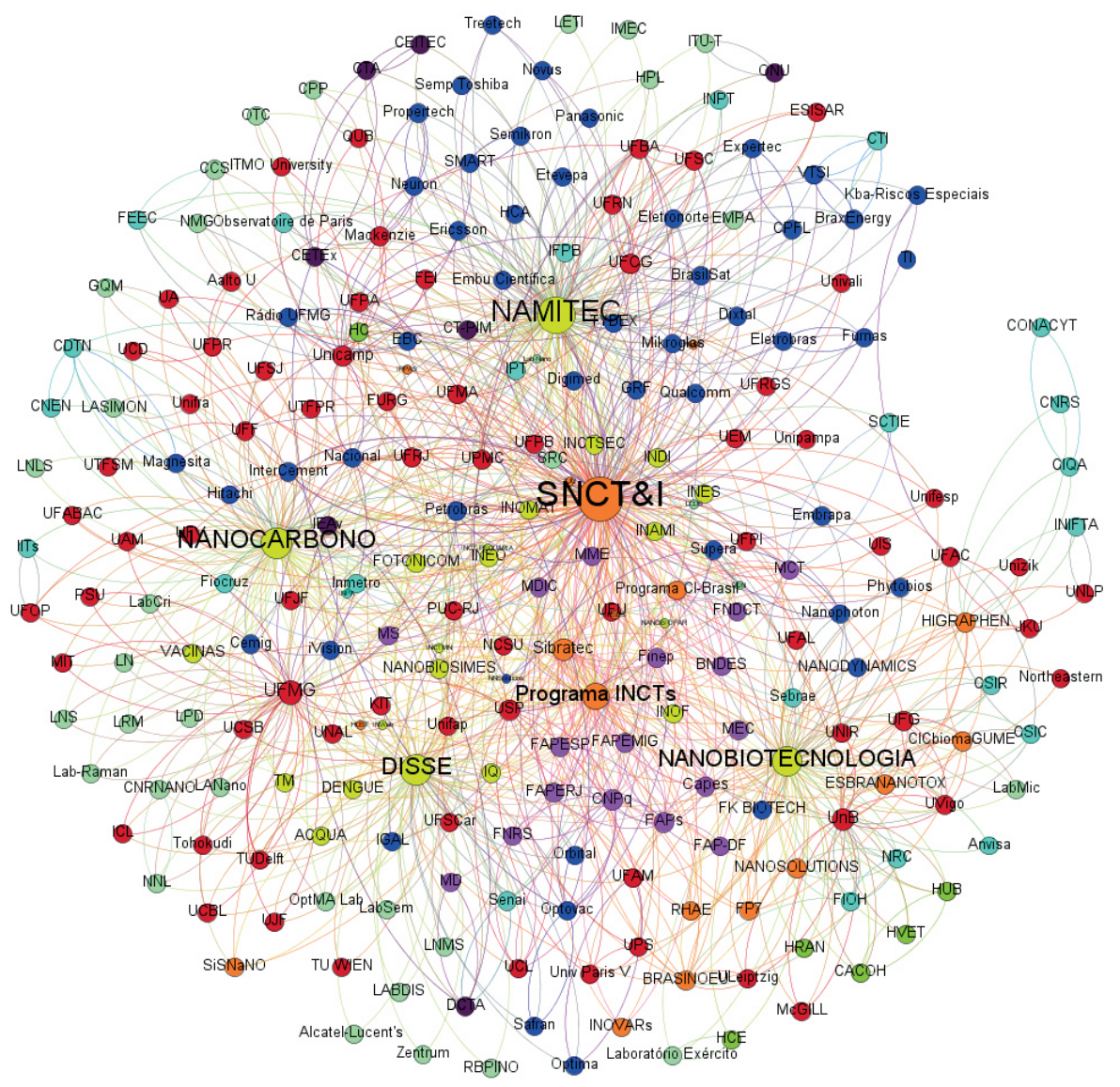

Fonte: Elaboração da autora. 
Contemplar o invisível e transformar suas propriedades em aplicações úteis para a sociedade foi uma das ambições identificadas na área de Nanotecnologia. Tornar o invisível visível para poder ser analisado foi o que propuseram Urs e Sharma (2010) com a utilização da análise das redes sociais. Uma das contribuições da pesquisa realizada foi a combinação que permitiu a visualização das interações e práticas colaborativas ocorridas na área de Nanotecnologia com o instrumental da ARS. Um desafio realizado de modo satisfatório.

O resultado das métricas da rede de práticas colaborativas para inovação foi apresentado no Quadro 13.

Quadro 13 - Métricas da Rede de Práticas Colaborativas para Inovação

\begin{tabular}{|l|c|}
\hline \multicolumn{2}{|c|}{ REDE DE PRÁTICAS COLABORATIVAS PARA INOVAÇÃO } \\
\hline \multicolumn{1}{|c|}{ MÉTRICA } & VALORES \\
\hline Grau médio & 4,81 \\
\hline Grau ponderado médio & 4,83 \\
\hline Densidade do grafo & 0,19 \\
\hline Modularidade & 0,44 \\
\hline Componentes conectados & 4 \\
\hline Coeficiente de claustering médio dos nós & 0,71 \\
\hline Cumprimento médio e caminho das arestas & 2,6 \\
\hline
\end{tabular}

Fonte: Elaboração da autora.

Os atributos de uma rede não são os seus principais elementos nem o principal foco de atenção. As conexões e interações entre os atores que a compõem são o foco central, conforme destacaram Wasserman e Faus (1994, p. 8, tradução nossa) em sua assertiva:

$\mathrm{Na}$ análise de redes sociais os atributos observados a partir dos atores sociais (tais como raça ou etnia das pessoas, ou o tamanho ou produtividade dos organismos coletivos, tais como empresas ou estados-nações) são compreendidos em termos de padrões ou estruturas de laços entre as unidades. As ligações relacionais entre atores são os focos primários e os atributos secundários. 
Contudo, o objetivo específico em atenção nesta seção focou a identificação das práticas e redes colaborativas para inovação, o que requereu atenção redobrada aos atributos para atender a esse requisito; apesar de serem considerados como elementos secundários, em uma análise de redes sociais, nesta pesquisa não poderiam ser negligenciados.

Uma síntese da identificação dos atores/actantes e atributos contemplados na rede foi apresentada no Quadro 14.

Quadro 14 - Atores/Actantes e atributos da rede

\begin{tabular}{|c|c|c|c|c|c|}
\hline \multirow[b]{2}{*}{ Ator/Actante } & \multicolumn{5}{|c|}{ Atributos } \\
\hline & Estrutura & $\begin{array}{l}\text { Dimensão } \\
\text { Jurídica }\end{array}$ & $\begin{array}{l}\text { Alcance } \\
\text { Geográfico }\end{array}$ & Prática colaborativa & Ambiente \\
\hline Aalto $U$ & Universidade & pública & estrangeiro & Formação de Recursos Humanos & externo \\
\hline ACQUA & INCT & pública & nacional & Colaboração Científica & interno \\
\hline Alcatel-Lucent's & Laboratório & pública & estrangeiro & Compartilhamento de Recursos & externo \\
\hline Anvisa & Instituição & pública & nacional & Colaboração Científica & externo \\
\hline BNDES & Agente de fomento & pública & nacional & Fomento & externo \\
\hline Brasilsat & Empresa & pública & nacional & Atividades de $P \& D$ & externo \\
\hline BRASINOEU & Políticas & pública & estrangeiro & Fomento & externo \\
\hline BraxEnergy & Empresa & privada & nacional & Atividades de $P \& D$ & externo \\
\hline $\mathrm{CACOH}$ & Hospital & pública & nacional & Colaboração Científica & externo \\
\hline Capes & Agente de fomento & pública & nacional & Fomento & externo \\
\hline CCS & Laboratório & pública & nacional & Compartilhamento de Recursos & externo \\
\hline CDTN & Instituição & pública & nacional & Colaboração Científica & externo \\
\hline CEITEC & Organização & pública/social & nacional & Formação de Recursos Humanos & externo \\
\hline Cemig & Empresa & mista & nacional & Atividades de $P \& D$ & externo \\
\hline CETEX & Organização & militar & nacional & Colaboração Científica & externo \\
\hline CICbiomaGUNE & Políticas & pública & estrangeiro & Colaboração Científica & externo \\
\hline CIQA & Instituição & pública & estrangeiro & Colaboração Científica & externo \\
\hline CNEN & Instituição & pública & nacional & Colaboração Científica & externo \\
\hline CNPq & Agente de fomento & pública & nacional & Fomento & externo \\
\hline CNRNANO & Instituição & pública & estrangeiro & Compartilhamento de Recursos & externo \\
\hline
\end{tabular}




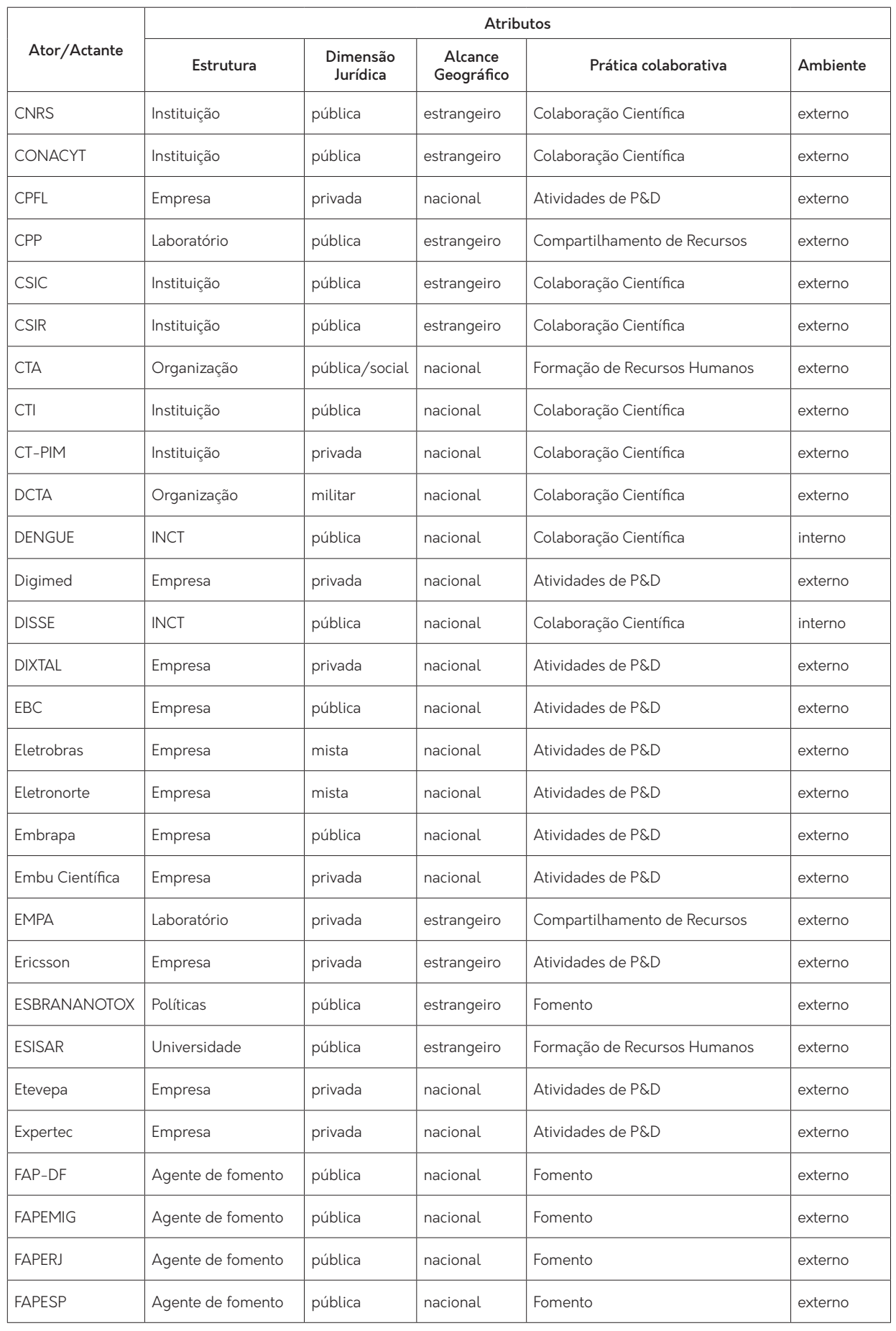




\begin{tabular}{|c|c|c|c|c|c|}
\hline \multirow[b]{2}{*}{ Ator/Actante } & \multicolumn{5}{|c|}{ Atributos } \\
\hline & Estrutura & $\begin{array}{c}\text { Dimensão } \\
\text { Jurídica }\end{array}$ & $\begin{array}{l}\text { Alcance } \\
\text { Geográfico }\end{array}$ & Prática colaborativa & Ambiente \\
\hline FAPs & Agente de fomento & pública & nacional & Fomento & externo \\
\hline FEEC & Instituição & pública & nacional & Formação de Recursos Humanos & externo \\
\hline FEI & Universidade & privada & nacional & Formação de Recursos Humanos & externo \\
\hline Finep & Agente de fomento & pública & nacional & Fomento & externo \\
\hline Fiocruz & Instituição & pública & nacional & Formação de Recursos Humanos & externo \\
\hline $\mathrm{FIOH}$ & Instituição & pública & estrangeiro & Formação de Recursos Humanos & externo \\
\hline FK BIOTECH & Empresa & privada & nacional & Atividades de $P \& D$ & externo \\
\hline FNDCT & Agente de fomento & pública & nacional & Fomento & externo \\
\hline FNRS & Agente de fomento & pública & estrangeiro & Fomento & externo \\
\hline FOTONICOM & INCT & pública & nacional & Colaboração Científica & interno \\
\hline FP7 & Políticas & pública & estrangeiro & Fomento & externo \\
\hline FURG & Universidade & pública & nacional & Formação de Recursos Humanos & externo \\
\hline Furnas & Empresa & mista & nacional & Atividades de $P \& D$ & externo \\
\hline GQM & Laboratório & pública & nacional & Compartilhamento de Recursos & externo \\
\hline GRF & Empresa & privada & nacional & Atividades de $P \& D$ & externo \\
\hline $\mathrm{HC}$ & Hospital & pública & nacional & Colaboração Científica & externo \\
\hline HCA & Empresa & privada & nacional & Atividades de $P \& D$ & externo \\
\hline HCE & Hospital & pública & nacional & Colaboração Científica & externo \\
\hline HIGRAPHEN & Políticas & pública & estrangeiro & Fomento & externo \\
\hline Hitachi & Empresa & pública & estrangeiro & Atividades de $P \& D$ & externo \\
\hline HPL & Laboratório & privada & estrangeiro & Compartilhamento de Recursos & externo \\
\hline HRAN & Hospital & pública & nacional & Colaboração Científica & externo \\
\hline HUB & Hospital & pública & nacional & Colaboração Científica & externo \\
\hline HUST & Políticas & pública & estrangeiro & Fomento & externo \\
\hline HVET & Hospital & pública & nacional & Colaboração Científica & externo \\
\hline $\mathrm{ICL}$ & Universidade & pública & estrangeiro & Formação de Recursos Humanos & externo \\
\hline IEAv & Organização & militar & nacional & Formação de Recursos Humanos & externo \\
\hline
\end{tabular}

Fonte: Elaboração da autora. 
$\mathrm{Na}$ rede de práticas colaborativas para inovação, os atributos constituíram um elemento a mais e foram imprescindíveis durante o rastreamento das conexões ocorridas, identificação necessária para responder à questão acerca do estabelecimento e solidificação das redes de colaboração nos INCTs.

A estrutura da rede de práticas colaborativas para inovação foi o primeiro atributo a ser pontuado nos resultados apresentados e permitiu identificar sob que alicerces estavam agregados os atores/actantes, nas relações colaborativas rastreadas e qual o papel por eles incorporado, a dimensão das interações e as parcerias realizadas. O Gráfico 22, permitiu a plena visualização dos resultados obtidos.

Gráfico 22 - Estrutura da Rede de Práticas Colaborativas para Inovação

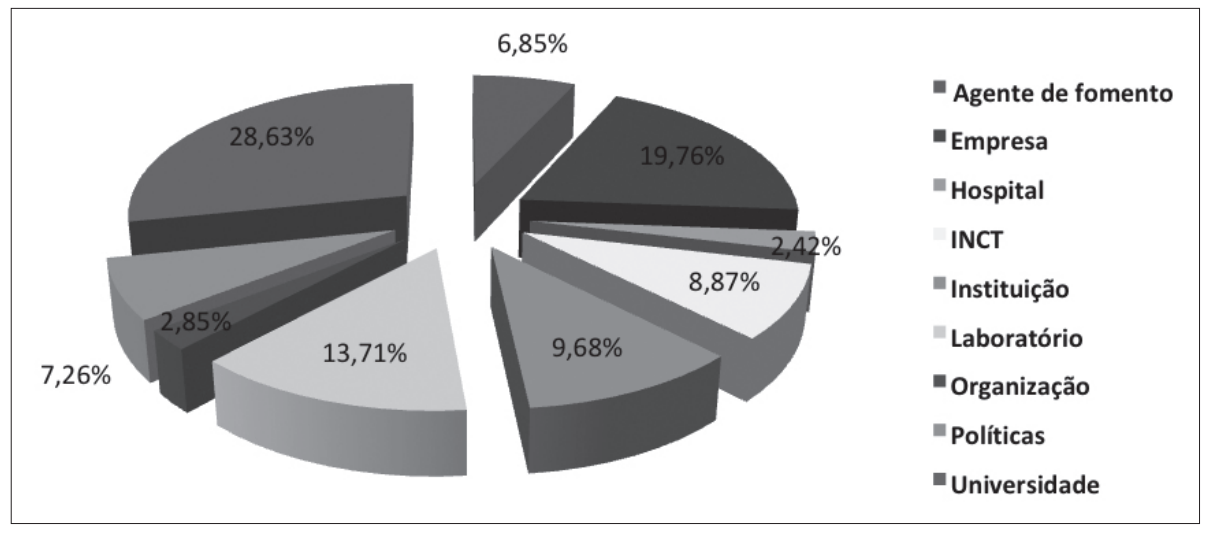

Fonte: Elaboração da autora.

O modelo do "Triângulo de Sabáto" considerou o governo, a universidade e a empresa como atores chaves que interagem para gerar inovação (ESCALATE LUDEÑA, 2008). Dentre os componentes da rede identificada, a universidade foi o que melhor se fez representar $(28,63 \%)$, percentual que a indicou como ambiente acadêmico tradicional e favorável para as práticas colaborativas realizadas e iniciativas para a inovação.

A seguir, as empresas (19,76\%) e o governo (14,11\%), representado pelos agentes de fomento e políticas. Os atores não considerados no modelo do "Triângulo de Sabáto” obtiveram representatividade significativa. Dentre esses, desta- 
caram-se os laboratórios (13,71\%), as instituições $(9,68 \%)$ e os INCTs $(8,87 \%)$; as organizações $(2,82 \%)$ e os hospitais $(2,42 \%)$.

A depender do papel incorporado pelos atributos identificou-se a atuação dos atores/actantes, como intermediários ou mediadores. Os intermediários e mediadores, resgatados do vocabulário de Latour (2012), determinaram a natureza íntima dos atores/actantes identificados na rede. Os intermediários transportaram significado e força sem transformar. Dos atores/actantes que incorporaram este papel, o resultado de suas ações e funções foi previsível.

Dos atores/actantes que incorporavam o papel de mediadores, ao contrário, os resultados eram imprevisíveis e eles puderam transformar traduzir, distorcer e modificar o significado ou os elementos que supostamente veiculavam e faziam parte de suas interações. O Quadro 15 sinalizou para a indicação atribuída aos atores/actantes, enquanto intermediários ou mediadores na rede apresentada. A rede de práticas colaborativas para inovação, possui um número reduzido de mediadores, mais com um forte poder de transformação, o qual caracterizou-se em um caldeirão de conexões que fervilhavam e modificaram os resultados obtidos nas interações realizadas.

Quadro 15 - Atores mediadores e intermediários da rede

\begin{tabular}{|l|c|}
\hline \multicolumn{1}{|c|}{ ESTRUTURA } & PAPEL \\
\hline Universidade & intermediário \\
\hline Políticas & mediadores \\
\hline Organização & intermediário \\
\hline Laboratório & intermediário \\
\hline Instituição & intermediários \\
\hline INCT & mediadores \\
\hline Hospital & intermediário \\
\hline Empresa & intermediários \\
\hline Agente de fomento & mediadores \\
\hline
\end{tabular}

Fonte: Elaboração da autora.

A dimensão jurídica característica dos atores/actantes foi o atributo identificado em seguida. A inserção dos atores/actantes na esfera pública (73\%) foi coe- 
rente com o perfil suposto para uma rede na qual ocorrem práticas colaborativas que necessitam de fomento, suporte e infraestrutura; os órgãos governamentais são os principais responsáveis por essa atribuição. Os atores/actantes inseridos na esfera privada (22\%) figuraram em percentual significativo no contexto do segmento representado, o qual necessita de estímulos e incentivos para se fazer presente, entretanto, ainda com um espaço muito vasto para inserção.

Identificaram-se ainda atores/actantes inseridos nas dimensões mista e mili$\operatorname{tar}(4 \%)$ e na pública com um cunho social (1\%). O Gráfico 23 permitiu a visualização da representação pontuada.

Gráfico 23 - Dimensão jurídica da rede

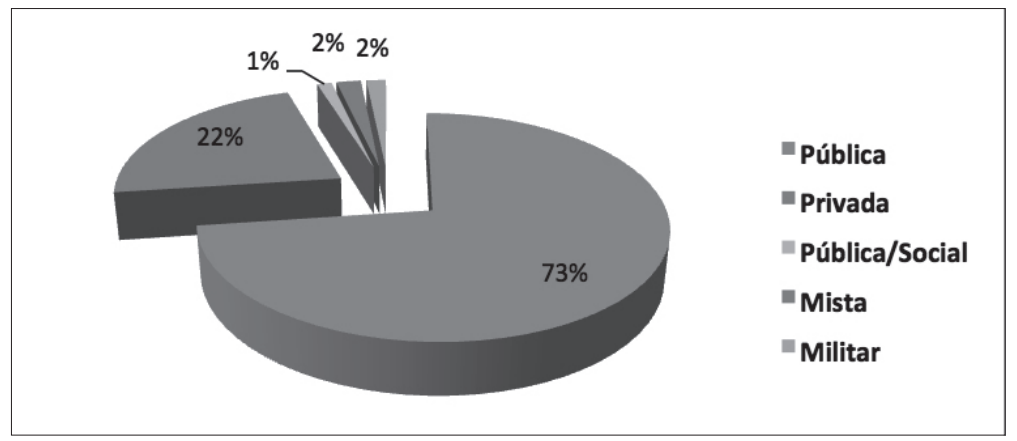

Fonte: Elaboração da autora.

Em termos espaciais, a maioria dos atores/actantes da rede (70\%) ainda estão restritos ao âmbito nacional. $\mathrm{O}$ alcance geográfico coberto pelos atores/actantes da rede sinalizou para a necessidade de maior inserção na esfera estrangeira (30\%). Tomando-se por base o amplo desenvolvimento da área da Nanotecnologia no mundo, fazem-se necessários investimentos direcionados a maior inserção internacional. Essa é uma das metas do Programa INCT e, apesar dos esforços empreendidos, são prementes novas parcerias com vistas a implementar esse aspecto. O Gráfico 24 ilustrou os percentuais obtidos por cada esfera geográfica. 
Gráfico 24 - Alcance geográfico da rede

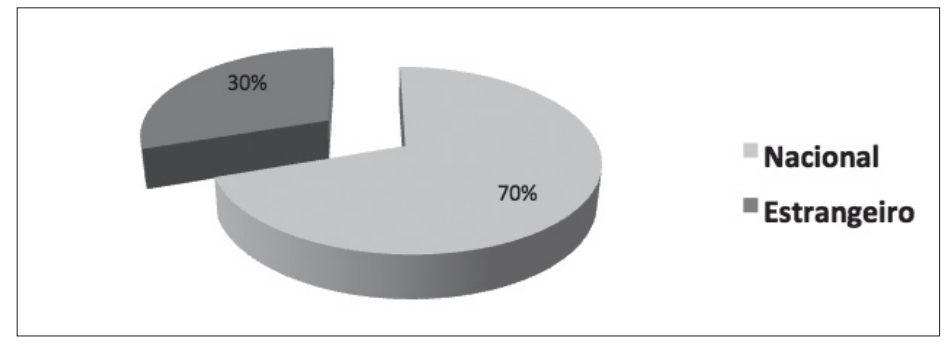

Fonte: Elaboração da autora.

Durante o rastreamento das conexões segmentadas foi possível identificar o tipo predominante das práticas realizadas pelos atores/actantes da rede. A característica da interação realizada foi um dos resultados obtidos, a qual justificou a atenção desprendida na análise dos atributos da rede. Neste momento, as atividades apresentadas foram agregadas de acordo com a natureza.

Faz-se oportuno registrar, que apesar da quantificação do resultado sinalizar para apenas uma indicação do tipo de prática contemplada foi constatada a ocorrência ao mesmo tempo, da realização de vários tipos, pelos atores/actantes. Este comportamento foi identificado também nos resultados das práticas colaborativas nos INCTs analisados. Para efetuar uma quantificação coerente levou-se em consideração os atores envolvidos na interação e as atividades predominantes do grupo em análise. Por exemplo, a prática da colaboração científica que permeou as diversas interações foi contabilizada, apenas nas estruturas que efetivamente the era peculiar e ocorria com uma maior regularidade. Nos laboratórios a predominância foi pelo compartilhamento de recursos, contudo a colaboração científica e a formação de recursos humanos também ocorriam. Desse modo, privilegiou-se a indicação na atividade de compartilhamento por ser mais frequente.

Observou-se harmonia entre os resultados obtidos na rede e nos relatórios analisados, no que se refere às efetivas práticas colaborativas realizadas. A colaboração científica, com um percentual de 22,18\% manteve sua frequência de realização entre atores/actantes da rede. Conforme se pode confirmar no Gráfico 25 . 
Gráfico 25 - Práticas colaborativas na rede

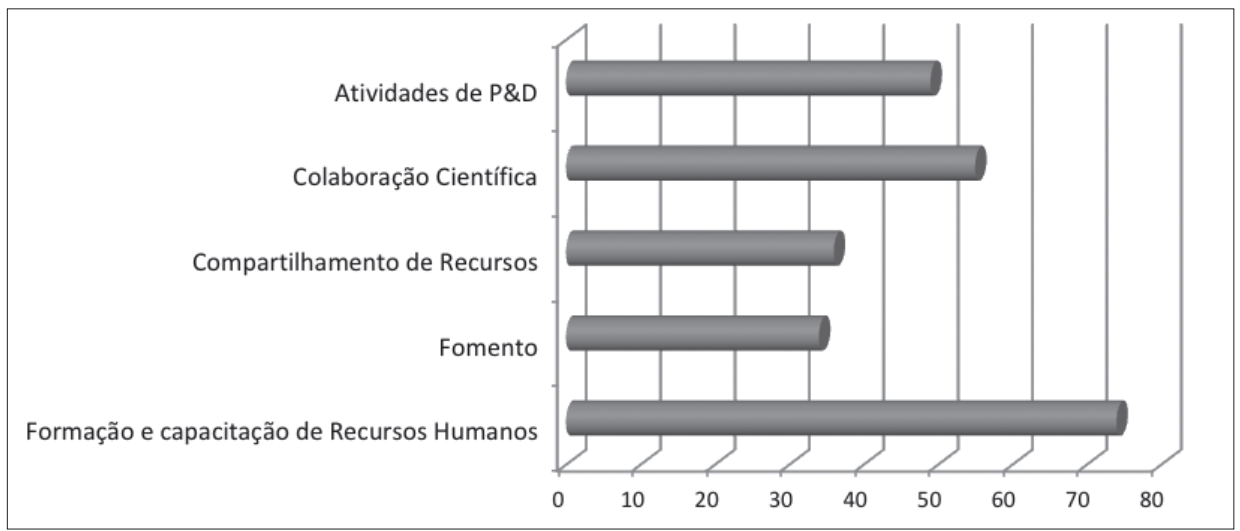

Fonte: Elaboração da autora.

As atividades de $\mathrm{P} \& \mathrm{D}(19,75 \%)$ sinalizaram a crescente presença das empresas no âmbito das parcerias colaborativas implementadas e o compartilhamento de recursos (14,51\%) indicaram o aproveitamento de equipamentos tão característico das práticas colaborativas. A interação para a formação e capacitação de recursos humanos registrada na rede $(29,84 \%)$ corroborou os índices contemplados na análise das práticas colaborativas pertinentes aos INCTs e a colaboração científica confirmou a presença dessa atividade de modo ativo nas interações realizadas.

$\mathrm{O}$ ambiente em que ocorreram as práticas colaborativas na rede foi efetivamente externo (91\%) em detrimento do ambiente interno (9\%). O Gráfico 26 ilustrou o resultado obtido.

Gráfico 26 - Práticas colaborativas - Ambiente

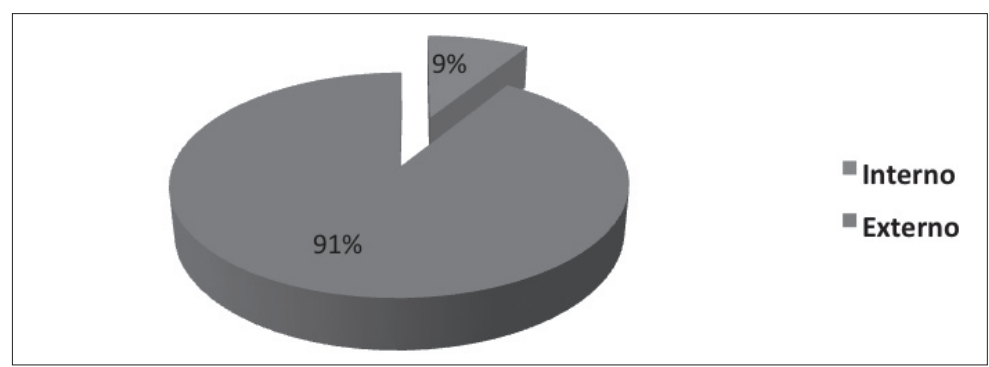

Fonte: Elaboração da autora. 
As práticas colaborativas internas foram caracterizadas pelas interações realizadas entre os INCTs. A interação entre os institutos, específicos da área de Nanotecnologia foi pequena levando-se em conta as práticas realizadas com os atores/actantes do ambiente externo identificadas nas acentuadas conexões. As interações com o ambiente externo são muito bem-vindas pois expande o alcance da rede. Contudo, os INCTs da área de Nanotecnologia analisados precisam ampliar as colaborações no âmbito interno, esse comportamento solidificará as redes existentes e permitirá abertura para novas interações. Parcerias bem acolhidas e necessárias para o fortelecimento do Programa INCT.

\section{Produção científica dos pesquisadores dos INCTs de Nanotecnologia}

A produção científica dos pesquisadores dos INCTs da área de Nanotecnologia foi analisada contemplando-se as seguintes variáveis: tipologia documental; produtividade; autoria; título, idioma e nacionalidade da fonte de publicação². Essas variáveis conduziram a análise e discussão dos resultados, os quais responderam ao terceiro objetivo específico da pesquisa: levantar a produção científica dos institutos selecionados no período que compreende os anos de 2008 a 2014, período de vigência dos institutos em sua primeira edição.

A tipologia documental foi indicada conforme encontrado na Plataforma Lattes, e assim discriminada: artigos completos publicados em periódicos nacionais e estrangeiros; livros publicados/organizados ou edições; capítulos de livros publicados; e trabalhos completos publicados e apresentados em anais de congressos. A título de padronização e busca pela uniformidade na tabulação dos dados desprendeu-se atenção à nomenclatura empregada para as variáveis.

Os ajustes realizados na nomenclatura da tipologia documental suprimiram as expressões longas e contemplou apenas palavras simples. A expressão artigos completos publicados em periódicos foi substituído pela palavra artigo. Os

2 Neste livro apresentamos apenas a tipologia documental da produção cientifica dos pesquisadores da área de Nanotecnologia, os dados completos da pesquisa podem ser consultados em Ferreira (2018). 
livros publicados/organizados ou edições passaram a ser identificados apenas como livros. Os capítulos de livros publicados foram especificados como capítulo. Os trabalhos completos publicados em anais de congressos foram apresentados apenas como anais e as apresentações de trabalhos em eventos como apresentação de trabalhos.

A quantificação total da produção científica coletada foi apresentada; o resultado desta coleta de dados representou a soma de 7.630 publicações e compreendeu: 3.054 artigos; 2.542 anais; 82 livros; 252 capítulos; 1.633 apresentações de trabalhos; 67 produções bibliográficas indicadas pelos pesquisadores como de tipos diversos; e 39 publicações recuperadas pelo software livre scriptLattes, mas sem indicação de ano, contudo.

A representação desta produção foi ressaltada no Gráfico 27. Os artigos, anais e apresentações de trabalhos foram as produções mais significativas dos pesquisadores dos INCTs da área de Nanotecnologia no período de 2008 a 2014. Essas produções perfizeram o total de 7.146 documentos. Percebe-se, ao observar o Gráfico 27, a prevalência dessas três tipologias documentais no período de coleta em decorrência do somatório que representam.

Gráfico 27 - Tipologia documental da produção científica

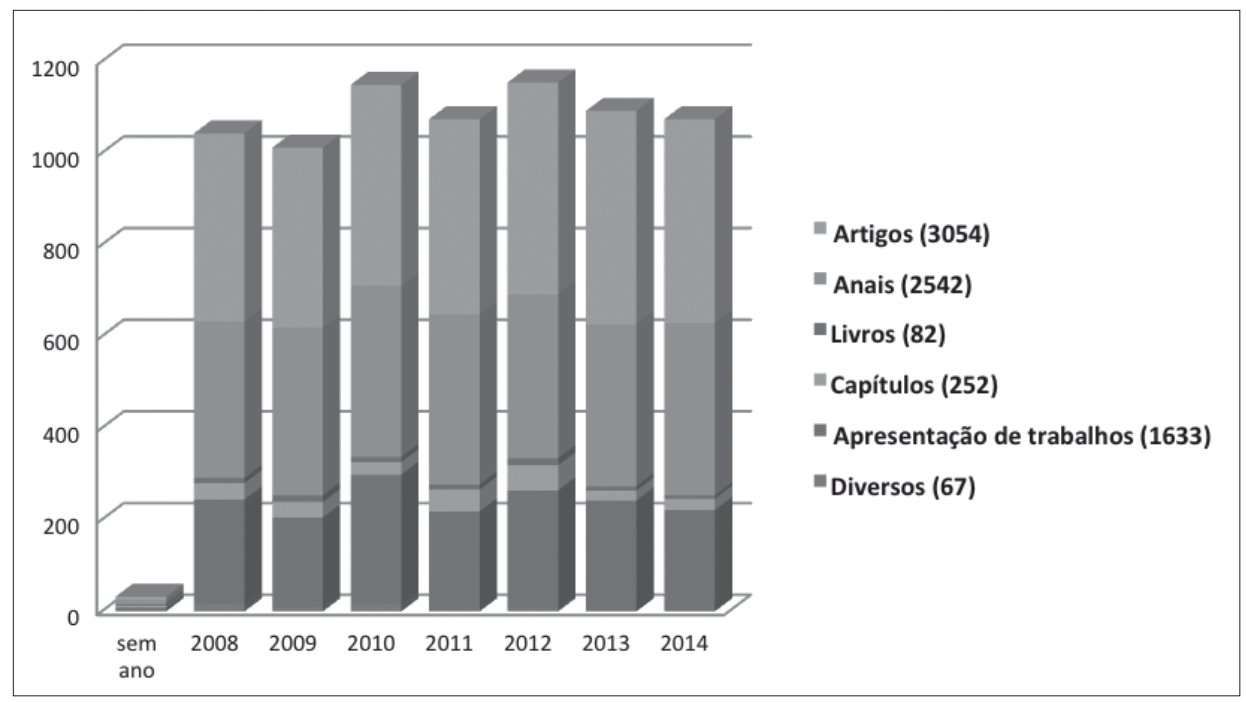

Fonte: Elaboração da autora. 
No conjunto em destaque ficou evidente, a supremacia da produção de artigos, em detrimento das outras tipologias. A produção dos anais aproximou-se em alguns períodos da produção dos artigos, especialmente no ano de 2009, no qual foi registrada a diferença de apenas 29 trabalhos. Esse resultado indicou uma cultura que privilegia a publicação em artigos na área investigada.

Os periódicos foram considerados por Mueller (2005) como o veículo mais usado para publicação pelos pesquisadores das áreas das Ciências Exatas, Biológicas, e da Saúde e os pesquisadores das Engenharias indicaram o uso desse veículo de modo intermediário. O resultado obtido na pesquisa contemplou as observações, por ter se registrado uma forte presença das Ciências Exatas, Biológicas e Engenharias no perfil dos pesquisadores analisados.

A produção de livros com um total de 82 publicações, e de capítulos de livros, 252 publicações foram pequenas na área se comparads com as outras produções; isso reforçou a assertiva de que estas tipologias documentais não possuem preferência para produção e divulgação dos resultados de pesquisa na área investigada. Constatou-se que a prioridade foi dispensada a produção de artigos de periódicos e trabalhos publicados em anais, resultado que se tornou relevante ao ser confrontado com o objetivo da pesquisa. Quanto maior a produção de artigos e participação em eventos, maiores as oportunidades para se fortalecerem as parcerias e se buscar novos trabalhos em colaboração.

Os motivos para a preferência pelas tipologias pontuadas pode tender para lados diversos, além dos pontuados por Mueller (2005). Apesar de essa análise não ser foco da pesquisa, sinalizou algumas suposições: predominância de pesquisadores com formação na área das ciências naturais, como comprovado na caracterização dos cientistas que atuam nos INCTs da área de Nanotecnologia. Essa predominância leva à preferência por divulgação da produção científica em artigos de periódicos e anais, veículos mais utilizados para comunicação científica nessas áreas. Entre as razões para a preferência creditam-se: a pontuação atribuída pelas agências de fomento quando da avaliação da área de pesquisa; a rapidez na divulgação e disseminação dos resultados de pesquisa, comparando-se aos outros veículos; fomento investido nos institutos revertidos em pesquisas que apresentam seus resultados nos artigos e anais. 
As inferências suscitadas com a análise do quantitativo geral da produção científica dos pesquisadores dos INCTs da área de Nanotecnologia foram apresentadas à medida que os resultados foram pontuados. Os artigos de periódicos registraram uma produção crescente com algumas oscilações nos anos analisados. Os anos de 2009, 2011 e 2014 sinalizaram um decréscimo,comportamento creditado ao atraso no repasse de verbas e quebra da motivação de alguns pesquisadores dos INCTs analisados. A incerteza quanto à continuidade do programa, em especial no ano de 2014, foi um dos motivos para a baixa produtividade.

A produção em anais manteve-se constante, com o registro de crescimento no ano de 2014, ao contrário dos artigos, que registraram uma queda na produção nesse ano. Conforme assertiva de Meadows (1999) as comunicações apresentadas em eventos são comuns na área das engenharias, outra área de formação presente no perfil dos pesquisadores dos INCTs de Nanotecnologia. A avaliação pelos pares de anais lhes confere um peso equivalente aos artigos de periódicos. Mueller (2005, p. 6) complementa "confirmando a literatura, os dados mostram que para as Engenharias, os anais de congressos são canais prestigiosos e frequentes na comunicação da área." As apresentações de trabalhos registraram um boom em 2010, mas a manteve-se constante partir desse ano. Em 2014, também registrou-se uma queda em sua produção.

Os livros registraram um comportamento de produção sempre baixo, acompanhados pelos capítulos dos livros por pequena margem de diferença. O período de maior produção de capítulos de livros foi em 2012 e daí em diante manteve-se constante. Um comportamento compreensível em uma área onde este veículo de comunicação científica não se encontra entre os preferidos. O Gráfico 28 registrou os resultados analisados. 
Gráfico 28 - Comportamento observado na produção científica

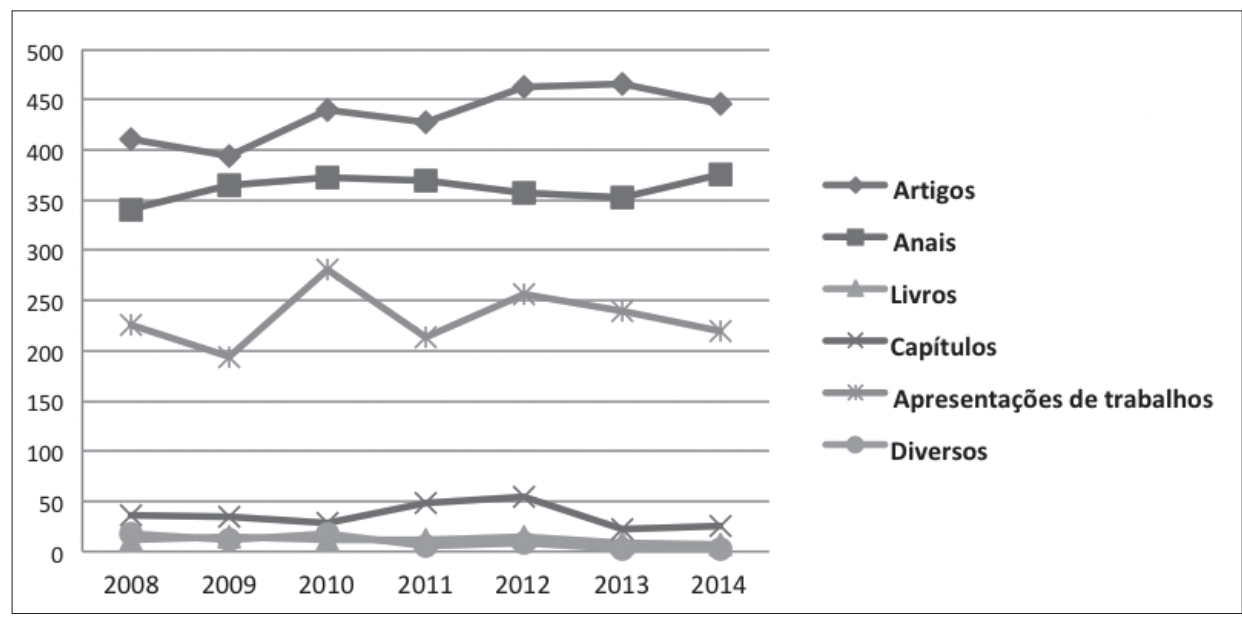

Fonte: Elaboração da autora.

O tratamento realizado nos dados da produção científica extraída da Plataforma Lattes pelo software scriptLattes atribuiu-lhes maior confiabilidade. Os dados foram conferidos e seu quantitativo contabilizado e padronizado.

Esse foi um trabalho árduo, mas necessário, devido ao porte da pesquisa realizada e à quantidade de dados recuperados, cuidado tomado com vistas a suprimir algumas inconsistências relativas a nome de autor, título do documento, topologia documental etc., apesar do tratamento contra redundâncias realizado anteriormente pelo software scriptLattes. As correções sanaram distorções quanto aos totais da produção e problemas de digitação no momento da inserção dos dados na Plataforma Lattes pelos pesquisadores dos INCTs da área de Nanotecnologia.

\section{Infraestrutura e suporte para pesquisa: INCTs e modelo e-Science}

Iidentificar a infraestrutura e suporte para pesquisa provenientes da implantação dos institutos da área de Nanotecnologia e sua correlação com o modelo de infraestrutura e-Science foi o quatro objetivo da pequisa realizada. Reconhecer os objetos que correspondiam ao coletivo das práticas colaborativas para inovação realizadas nos INCTs e sua relação de causa e efeito com o fenômeno da e-Science o complementou. 
Para a apresentação desses resultados, foi necessário destrinchar os elementos-chave desse objetivo e identificar os objetos que o caracterizavam. Na análise foram contemplados: o modelo INCT, política pública de fomento para pesquisa em Ciência Tecnologia e Inovação selecionada; e o modelo e-Science, como padrão para um fazer científico renovado, de práticas colaborativas voltadas para a pesquisa e todo o arcabouço tecnológico que o congregava.

Tomou-se como base para investigação a terceira fonte de incerteza, indicada por Latour (2012) como a natureza dos objetos. Os elementos que compunham a infraestrutura tanto dos INCTs quanto da $e$-Science, foram esmiuçados para contemplar o objetivo proposto.

O modelo INCT foi representado pelos institutos da área de Nanotecnologia contemplados na seção 3 desse livro. Essa seção continha as informações preliminares que os caracterizavam: a localização de sua sede, os pesquisadores que atuavam nos institutos e a natureza do grupo. A seção atual contemplou os outros indicadores que representavam o modelo e conduziram a análise do quarto objetivo específico da pesquisa como: a percepção do modelo INCT, na ótica dos seus membros; a infraestrutura existente para pesquisa e os recursos informacionais digitais utilizados pelos pesquisadores dos institutos.

Os depoimentos dos coordenadores entrevistados, intercalados com os achados dos relatórios de acompanhamento de projeto compuseram os resultados apresentados sobre a percepção acerca do modelo INCT, as razões que os influenciaram a participar do projeto e as vantagens obtidas com a experiência. O Quadro 16 contemplou os relatos.

Quadro 16 - Modelo INCT - Percepção

\section{MODELO INCT - PERCEPÇÃO}

na realidade para nós foi um processo natural porque nós já vinhamos trabalhando, eu comecei a trabalhar com Nanotecnologia em interação com grupos de outras áreas. [...]. E isso deu muito certo, porque a interação favoreceu com que o nosso trabalho andasse mais rápido, fizéssemos bons trabalhos e publicássemos mais. Quer dizer, quando você olha, você só vê vantagem naquela espécie de colaboração. [...] Quando veio o INCT nós já trabalhávamos como INCT, não como INCT mas como rede, então esse foi um processo absolutamente natural.

foi muito produtivo nesse sentido. Na área que nós trabalhamos, conseguimos juntar todas as pessoas que tinham atividades correlatas [...]. Reunimo-nos e pegamos gente especializada em várias atividades, várias instituições do país e nós conseguimos ter um avanço maior, porque nós conseguimos agregar conhecimentos afins [...] juntando competências de diferentes instituições. 
[...] são muito relevantes, são extremamente relevantes. É uma experiência muito bem sucedida, exatamente porque o Brasil é um país que não tem tantos recursos assim. Então nós temos que utilizar a forma otimizada de recursos e uma forma otimizada de usar os recursos é exatamente formar redes, está certo? E essa rede então nos permite usar esses recursos de uma forma mais eficiente e estimular a colaboração.

eu vejo como muito importante esse empreendimento, fortaleceu bastante a formação de recursos humanos, tanto dentro da rede, como ações externas como cursos, escolas para motivar jovens, outros estudantes de outra área ensinando, até divulgando a nossa área e orientações a respeito de como proceder à divulgação para estudantes e para a sociedade de um modo geral.

aqui o "efeito" INCT se fez sentir com bastante veemência, e acreditamos que esse objetivo foi alcançado com grande sucesso. [...] Em primeiro lugar, por tratar-se de um grupo multidisciplinar e interdisciplinar, os resultados que não poderiam ser obtidos por laboratórios isoladamente, por falta de expertise ou falta de equipamento, são alcançados de forma mais ágil e mais rápida.

desde a criação do instituto, as possibilidades de desenvolvimento de novos dispositivos otimizados se tornaram uma realidade com a inclusão da técnica de Algoritmo Genético no cálculo de projeto das amostras em estudo. Essa é uma área (inverse design) de ponta hoje em dia e a inclusão desse tema nas nossas atividades se mostrou bastante oportuna. A combinação de pesquisadores com experiência nessa técnica de Inteligência Computacional com outros de desenvolvimento de materiais e dispositivos, todos dentro do [...], possibilitará um avanço ainda maior na engenharia de materiais que envolvem o design de amostras específicas, de forma a obter o desempenho desejado do dispositivo.

[...] a fundação do INCT possibilitou uma concentração dos esforços brasileiros que aumentaram consideravelmente a qualidade das pesquisas desenvolvidas e permitiram alcançar o patamar internacional.

Fonte: Elaboração da autora.

Infere-se, com a análise dos resultados apresentados, que a implementação dos INCTs favoreceu e solidificou as redes de pesquisadores existentes e que atuavam em áreas correlatas à Nanotecnologia. Os institutos foram considerados como continuidade de ações que eram realizadas antes de sua criação. O Programa INCT foi um estímulo a mais para os pesquisadores e oportunidade de abertura de novas frentes de pesquisa que contemplavam a multidisciplinaridade apresentada; uma possibilidade de avanço significativo em áreas antes não apreciadas. Novas redes colaborativas também foram constituídas e os saldos para um programa dessa magnitude foram positivos. A inovação presente no desenvolvimento de novos dispositivos tornou-se realidade e vários foram os aspectos citados que direcionaram para essa assertiva. Dentre esses os abaixo listados:

- agregação de pesquisadores com atividades correlatas;

- agregação de pesquisadores com especialidades distintas; 
- agregação de pesquisadores de instituições diversas do país;

- maior avanço na pesquisa, especialmente em áreas antes não contempladas;

- agregação de conhecimentos afins e competências de diferentes instituições;

- otimização de recursos;

- fortalecimento na formação de recursos humanos;

- desenvolvimento de tecnologia inovadora;

- fortalecimento do trabalho em redes colaborativas.

Conforme previsto pela Portaria MCT No 429, de 17 de julho de 2008, os INCTs deveriam ser formados em uma instituição sede, caracterizada pela excelência de sua produção científica e tecnológica, alta qualificação na formação de recursos humanos e com capacidade de alavancar recursos de outras fontes, e por um conjunto de laboratórios ou grupos associados de outras instituições, articulados na forma de redes científico tecnológicas (BRASIL, 2008).

O Edital n ${ }^{\circ}$ 15/2008 do MCT indicou as características que deveriam ser contempladas pela instituição sede conforme foi apresentado.

A instituição sede, caracterizada pela excelência da produção científica e tecnológica, alta qualificação na formação de recursos humanos deve:

- demonstrar que já tem capacidade de captar recursos de outras fontes;

- dispor de espaço físico e infraestrutura que possibilitem uma caracterização visível do Instituto Nacional;

- garantir o uso da estrutura física e participação de pesquisadores e técnicos no desenvolvimento do projeto e, quando pertinente, oferecer recursos de contrapartida para o desenvolvimento do mesmo, por documento da autoridade maior (CNPq, 2008).

A infraestrutura existente no INCT disponibilizada pela instituição sede identificada nos relatórios compreendeu em sua maioria: o espaço físico para 
reuniões e encontros eventuais entre os pesquisadores; o acesso às instalações da sede e a disponibilidade para o uso de telefone, computador e internet; espaço físico para construção de laboratório; equipamentos específicos para as pesquisas realizadas; e um funcionário de apoio contratado por alguma fundação, ou designado pela instituição.

O Quadro 17 indicou os resultados obtidos de acordo com os INCTs investigados e permitiu avaliar se a infraestrutura oferecida estava alinhada com as exigências do edital 15/2008.

Quadro 17 - Infraestrutura INCT

\begin{tabular}{|l|l|}
\hline \multicolumn{1}{|c|}{ INFRAESTRUTURA INCT } \\
\hline DISSE & $\begin{array}{l}\text { sala de reuniões, auditório para workshop, espaço físico } \\
\text { para construção de um laboratório onde foi instalado o } \\
\text { novo equipamento de epitaxia (CONSELHO NACIONAL DE } \\
\text { DESENVOLVIMENTO CIENTÍFICO E TECNOLÓGICO, 2013f). }\end{array}$ \\
\hline \multirow{5}{*}{ NAMITEC } & $\begin{array}{l}\text { uma sala, um funcionário contratado, acesso ao uso do telefone, } \\
\text { impressão, e infraestrutura geral da instituição (CONSELHO } \\
\text { NACIONAL DE DESENVOLVIMENTO CIENTIIFICO E TECNOLÓGICO, } \\
\text { 2014b). }\end{array}$ \\
\hline NANOBIOTECNOLOGIA & $\begin{array}{l}\text { computador, impressora a leser e uma secretária. A infraestrutura } \\
\text { criada pelo INCT juntou-se aos recursos do Pro-Infra Finep para } \\
\text { construção de um prédio onde foi disponibilizado área para dois } \\
\text { laboratórios de Nanotecnologia. Equipamentos para métodos } \\
\text { de caracterização e para realização de testes in vitro e in vivo } \\
\text { (CONSELHO NACIONAL DE DESENVOLVIMENTO CIENTÍFICO E } \\
\text { TECNOLÓGICO, 2013d). }\end{array}$ \\
\hline NANOCARBONO & $\begin{array}{l}\text { espaçO físico para reuniões do comitê gestor e infraestrutura para } \\
\text { comunicações entre os membros deste comitê como: telefone e } \\
\text { internet. Um professor adjunto contratado. Implementação do Centro } \\
\text { de Tecnologia em Nanotutos (CT-Nanotubos) (CONSELHO NACIONAL } \\
\text { DE DESENVOLVIMENTO CIENTÍFICO E TECNOLÓGICO, 2013e). }\end{array}$ \\
\hline
\end{tabular}

Fonte: Elaboração da autora.

Os resultados obtidos confirmaram que as exigências foram contempladas e a infraestrutura oferecida pela instituição sede estava de acordo com o que foi previsto no Edital no 15/2008. Configurou-se, desse modo, a observância entre o que foi exigido no edital citado e o que foi apresentado pelos INCTs. 
Para identificar a infraestrutura para pesquisa disponível nos institutos foi necessário resgatar o modelo de infraestrutura e-Science e fazer um contraponto. Não se utilizou um modelo que correspondesse à realidade da infraestrutura e-Science no país, devido à dificuldade para se obter resultados consolidados de iniciativas que caracterizassem o modelo pretendido. Contudo, utilizou-se como parâmetro a iniciativa do Programa $e$-Science implementada pela FAPESP, no que concerce a políticas de fomento a pesquisa, analisado na próxima seção desse livro.

O resgate dessa infraestrutura na literatura científica consultada imprimiu segurança à análise realizada. A infraestrutura e-Science, segundo Andronico e colaboradores (2011) foi denominada como e-infraestructure, ou seja, "um 'método científico' que prevê a adoção de plataformas digitais de ponta conhecidas como infraestruturas eletrônicas em todo o processo, da ideia à produção do resultado científico. Segundo os autores citados, essa infraestrutura eletrônica pode ser conceitualmente representada por três camadas:

- parte inferior, composta pelos instrumentos científicos e experimentos que fornecem grande quantidade de dados;

- em seguida, a camada de rede, centros de processamento de dados em rede e software middleware como a "cola" dos recursos;

- e o terceiro e mais alto nível que inclui pesquisadores que realizam suas atividades independente da localização geográfica, interagem com os colegas, compartilham e acessam os dados (ANDRONICO et al., 2011).

A representação das camadas da e-infraestructure apresentadas no capítulo que trata sobre a $e$-Science foi contemplada pela Figura 11, resgatada do contexto de apresentação inicial. 
Figura 11 - Modelo de Infraestrutura e-Science

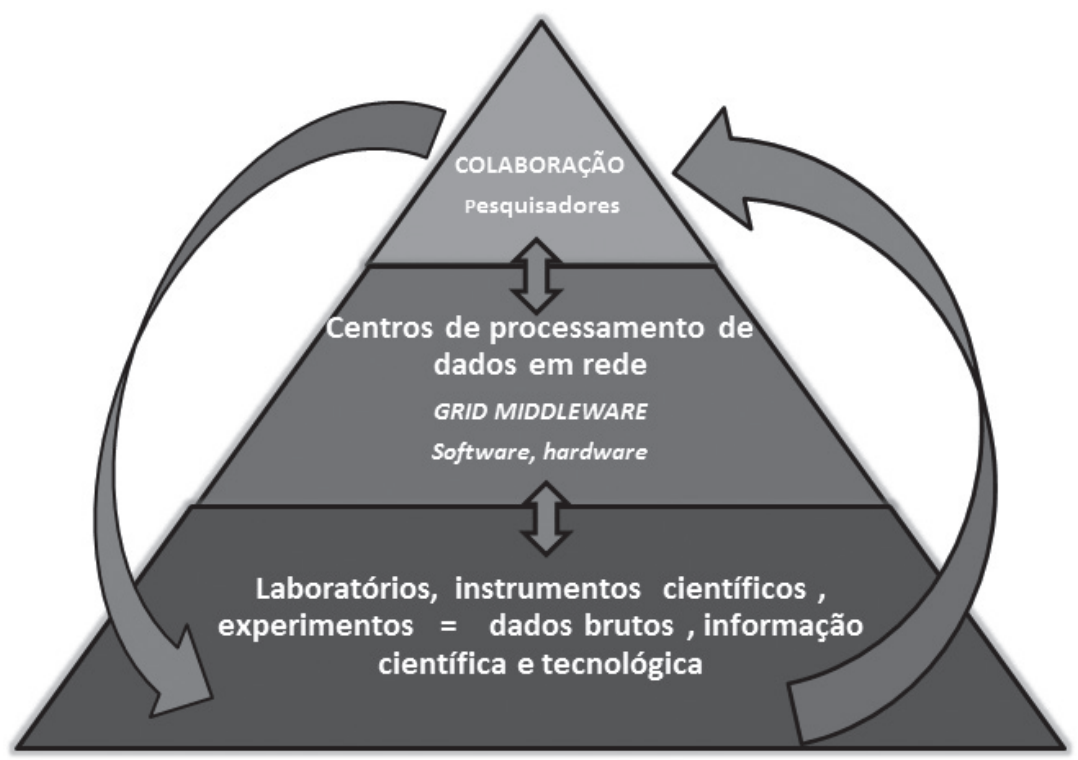

Fonte: Elaboração da autora baseada em Andronico e colaboradores (2011).

Esse aparato caracterizou uma infraestrutura voltada para grandes projetos colaborativos que envolviam a troca de volumes de dados em grande escala. Identificar nos INCTs a existência de uma infraestrutura tecnológica compatível com a prevista em um modelo $e$-Science perpassava a verificação dos serviços de suporte e infraestrutura para pesquisa e tratamento de dados por eles oferecidos, utilizados e mantidos em suas atividades colaborativas.

O questionamento relacionado a quais serviços eram contemplados pelos INCTs, dentro desses parâmetros, auxiliaram no diagnóstico pretendido. Registrou-se como o suporte mais sinalizado a indicação para os serviços de citação, publicação e distribuição de dados (29,7\%). Computou-se ainda a indicação para repositórios de dados (22\%); para as bibliotecas digitais (16,5\%); para a integração de dados (14\%), e para os colaboratórios (12,1\%). O grande destaque nos resultados obtidos recaiu sobre a sinalização para as respostas "nenhuma das opções indicadas" e "desconheço esses termos utilizados”, cuja soma dos percentuais representou $42,9 \%$ do total obtido entre todas as opções indicadas. O Gráfico 29 ilustrou o resultado obtido. 
Gráfico 29 - Serviços oferecidos no INCT X Infraestrutura e-Science

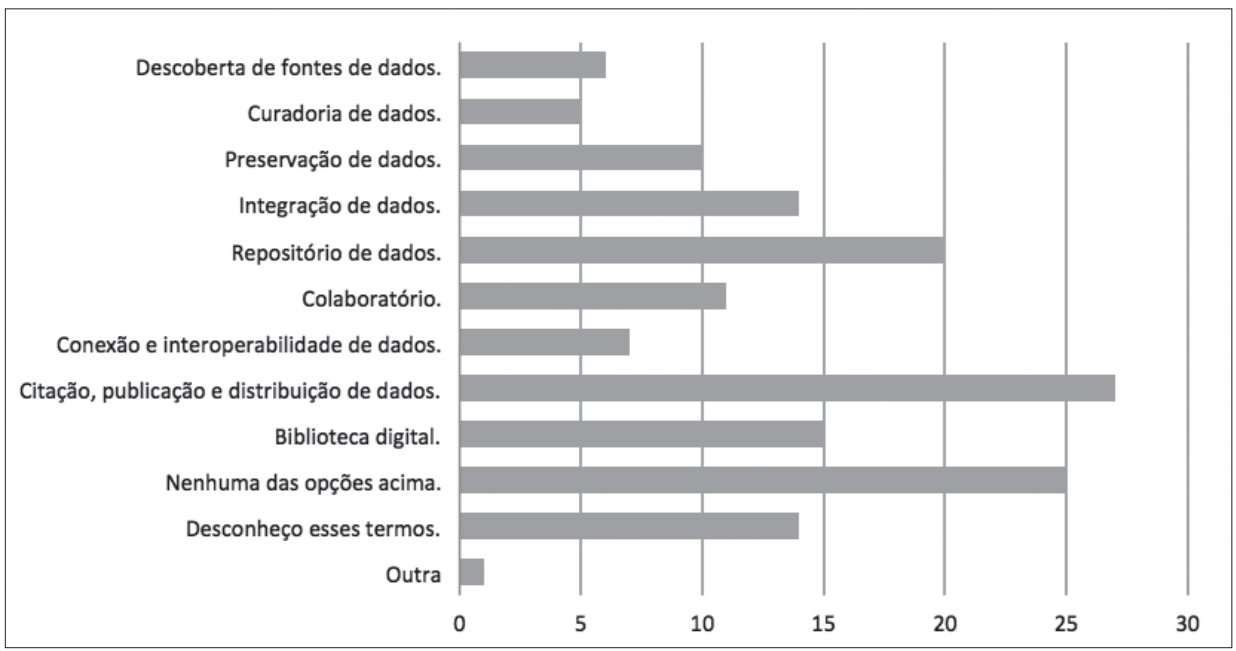

Fonte: Elaboração da autora.

Esse resultado permite afirmar que a existência de serviços característicos da infraestrutura e-Science é incipiente nos INCTs da área de Nanotecnologia investigados. Apesar do registro de existência de repositórios de dados, bibliotecas de dados e colaboratórios, o percentual foi relativo quando se leva em consideração as indicações de inexistência e desconhecimento sobre os termos que caracterizavam o serviço.

Quando questionados sobre a comparação entre a infraestrutura do INCT com o modelo de infraestrutura e-Science, os coordenadores consideram que o modelo e-Science não era estruturante das práticas colaborativas realizadas nos institutos, em sua maioria. Exceto um declarou que o INCT a que estava vinculado se enquadrava no modelo. Entretanto, concluiu-se que o fato de o conceito ser novo e desconhecido para o grupo investigado, conforme atestaram os pesquisadores em resposta a questionamento sobre o assunto, a prontidão na resposta gerou dívidas. Acredita-se que deve ter havido confusão com o significado exato do termo e sua real aplicação, o que suscitou imprecisão no momento da resposta. Os trechos destacados foram apresentados na sequência:

[...] não, ainda não fazemos uso dessas tecnologias.... não no nosso caso ainda não; 
nós do [...] nos enquadramos nesse modelo. O que fazemos, nós temos um grupo dentro do INCT, nós temos colaboradores que nessa parte de tecnologias de comunicação, [...] são bem focados nessa área. Então eles na realidade difundem dentro do grupo essas práticas digamos assim. Mas digamos não é todo mundo que está envolvido, aí eles tentam de tudo... esse grupo mais especializado digamos mais perto da e-Science, eles tentam nos puxar;

[...] pelo menos por enquanto não, até poderá vir a ser, é uma coisa interessante, o mundo está ficando cada vez mais baseado nessas trocas de informações através dos meios eletrônicos, mas no nosso INCT, eu the digo francamente que não foi algo estruturante;

nós usávamos o webc também para fazer reuniões e usávamos um site para repositório, no laboratório, mas nada assim como um estudo sobre a tecnologia e-Science. Nós usamoos as ferramentas;

A tecnologia ajuda mas não é...

Infere-se, com os resultados obtidos que não existe adequação entre a infraestrutura para pesquisa nos INCTs da área de Nanotecnologia e a infraestrutura $e$-Science, apesar de existirem alguns elementos semelhantes entre os dois modelos, como por exemplo, o aporte financeiro significativo da iniciativa pública e o forte perfil colaborativo apresentado nas redes colaborativas. Conclui-se, desse modo, que o quarto objetivo específico foi contemplado quando se respondeu ao questionamento realizado sobre a infraestrutura e suporte para pesquisa presentes nos INCTs e sua atenção ao solicitado pelo Programa INCTs.

Observou-se, ampla utilização dos recursos informacionais digitais, o que pode ter favorecido a interpretação dos coordenadores quanto à adequação do modelo INCT ao modelo e-Science. A indicação da utilização desses recursos reforçou a assertiva de que os pesquisadores dos INCTs de Nanotecnologia são usuários ativos dos artefatos tecnológicos contemporâneos. Entretanto, isso não os caracteriza como pesquisadores que desenvolvam projetos os quais utilizam grandes volumes de dados para a realização de suas práticas colaborativas, nem que esse seja o alvo predominante de suas pesquisas.

Os artefatos tecnológicos contemporâneos indicados foram: e-mail, Skype, redes sociais, intranet, internet e alguns softwares proprietários de compartilhamento 
de recursos digitais e apoio na realização de videoconferência. O Quadro 18 contemplou a indicação dos artefatos utilizados, conforme informações dos coordenadores dos INCTs.

Quadro 18 - Recursos informacionais digitais

\section{RECURSOS INFORMACIONAIS DIGITAIS}

não, nós temos uma intranet, uma rede nossa, nós usamos Facebook, Twiter...., e as redes sociais. Nós temos um desenvolvido por nós, uma intranet, uma rede nossa que junta todos os grupos, e tem esse software que te falei que é como se fosse um laboratório virtual que nós colocamos todos os dados, todo mundo tem acesso.

webs, e-mail, Skype, Google Docs, na elaboração de propostas, de artigos.

não, apenas uma minoria é que trabalha, a maioria não. Temos a ferramenta, oferecemos, divulgamos, mas assim, a verdade é que ela foi usada apenas por uma minoria de pesquisadores.

nós utilizávamos várias práticas que utilizam meios de comunicação [...]. Por exemplo, um software que usamos e colocamos as informações sobre as amostras que produzimos, os resultados, às vezes nos produzimos uma amostra, distribuímos para vários grupos que fazem investigações diferentes das mesmas amostras. Nós temos um banco de dados, digamos assim...

basicamente Skype e o e-mail, normalmente as informações que nos temos, quando tem alguma discussão. Essa discussão ou é feita por Skype ou é feita por e-mail, mas eu lhe digo novamente, isso às vezes é uma deficiência do coordenador ou da coordenação muito mais do que do grupo. Porque o grupo me cobra, vamos fazer isso, vamos fazer aquilo, agora só me cobrar não resolve.

Fonte: Elaboração da autora.

Os resultados obtidos permitiram a idealização do desenho, do modelo da infraestrutura INCT baseado nas práticas colaborativas para inovação e diversas interações identificadas, o qual fundamentou-se, para sua execução, nos depoimentos e resultados obtidos ao longo da pesquisa. Esse modelo foi formado por uma sede que representava a sua base, a qual era composta pela instituição sede dos INCTs e responsável pelo instrumental físico colocado à disposição dessa; e para representar o seu topo um grupo de pesquisadores concentrados em realizar as pesquisas e as interações com a camada intermediária. Embora ocorresse comunicação também com a camada intermediária, ambos estavam ligados diretamente à base.

A camada intermediária foi composta pela rede das práticas colaborativas entre os diversos atores/actantes identificados. Ela representou as conexões e 
interações entre estes nós e os pesquisadores dos INCTs, entre os quais encontravam-se: as universidade; as instituições; as organizações; as empresas; os laboratórios; os hospitais; as políticas; e os agentes de fomento. Todps esses responsáveis pela infraestrutura científica e tecnológica utilizada e compartilhada pelos pesquisadores dos INCTs da área de Nanotecnologia. Entretanto, na sede do INCT também se encontrava parte da infraestrutura utilizada nas colaborações. O modelo foi apresentado na Figura 12.

Figura 12 - Modelo de infraestrutura INCT

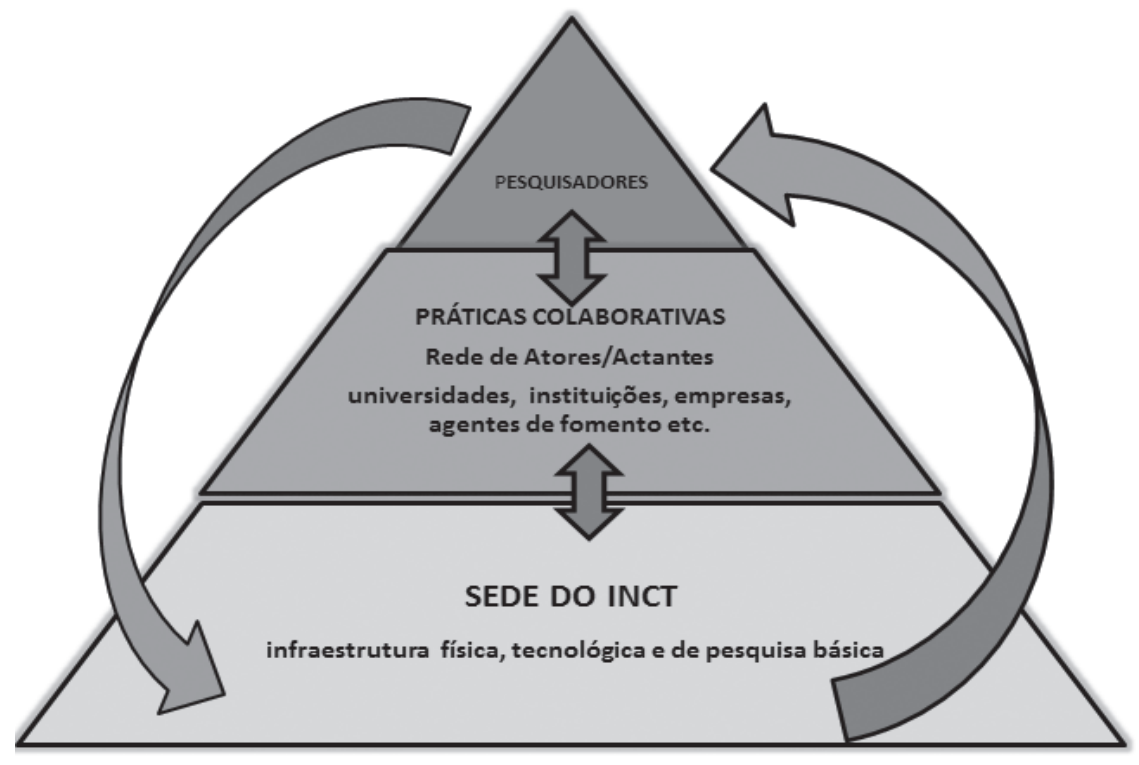

Fonte: Elaboração da autora.

Identificar a infraestrutura existente nos INCTs representou a primeira medida para identificar o modelo existente e poder compará-lo com o modelo $e-S$ cience. A próxima ação foi entender a noção predominante do termo e-Science nos institutos, o que permitiu entender o porquê de pesquisadores cujo perfil inclui a atuação com elementos da alta tecnologia, maioria, não realizarem projetos nos moldes e-Science.

O entendimento sobre o termo e-Science que predominou foi o de um conjunto de ferramentas e tecnologias necessárias para apoiar a pesquisa. Essa res- 
posta representou o percentual 59,3\%. e a noção do termo como metodologia de pesquisa científica obteve o percentual de $22 \%$ de respostas.

As opções para o entendimento do termo e-Science como uma nova forma de fazer ciência; e como um novo paradigma da ciência (quarto paradigma) corresponderam respectivamente a $17 \%$ e $9,9 \%$ das respostas obtidas. O Gráfico 30 apresentou o resultado completo.

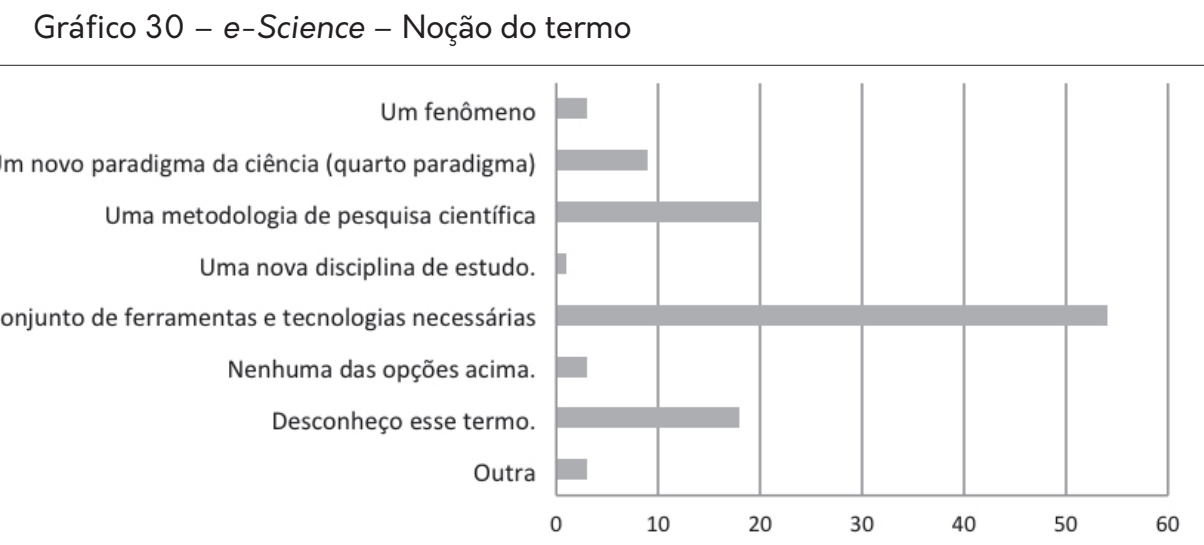

Fonte: Elaboração da autora.

As respostas sinalizaram o fato de os pesquisadores da área em investigação não serem totalmente leigos em relação ao termo $e$-Science. Isso se justifica por se tratar de uma área que inclui profissionais cujo perfil indica competência no trato com as tecnologias de informação e comunicação e, desse modo, estarem bem informados para as inovações da área. A despeito disso, parcela significativa ainda desconhece o termo (19,8\%), o que também se justifica pela multidisciplinaridade característica da área, a qual contempla profissionais que atuam em outras frentes de atuação em que, apesar de ser utilizada, a alta tecnologia não é objeto de discussão nem estudo.

A questão referente à noção do termo e-Science também foi alvo de pergunta, aos coordenadores dos INCTs nas entrevistas online realizadas; os resultados obtidos foram indicados a seguir, nos trechos destacados:

não, esse termo não como conceito...., como termo, eu com certeza posso falar pela maioria dos meus colegas, eles não conhecem. É um termo realmente novo; 
esse termo e-Science, nós não.... nunca falamos nele. No INCT, nas reuniões que fazemos nunca foi comentado. [...] Usamos essas metodologias e a comunicação eletrônica, mas o termo e-Science propriamente dito nós nunca utilizamos;

[...] acho que nunca usamos muito esse conceito;

bom com relação ao termo em si você vê, eu mesmo que sou coordenador nunca tinha ouvido falar.

Evidenciou-se, desse modo, o desconhecimento do termo $e$-Science entre os pesquisadores dos INCTs investigados, uma constatação que reforça a assertiva que justificou a não correlação do modelo INCT, com o Modelo de infraestrutura e-Science. Pelo menos, a infraestrutura identificada não contemplou a existência de um centro de processamento de dados responsável pela captura, curadoria e análise de grandes volumes de dados brutos e informação científica e tecnologia componentes da infraestrutura $e$-Science.

Questionou-se ainda sobre a existência de uma política, nos INCTs que contemplasse a gestão dos dados brutos, científicos e tecnológicos, uma das competências dos programas e-Science. Os resultados obtidos sinalizaram para o desconhecimento sobre a política e sua inexistência. O percentual das duas respostas somadas correspondeu a $68 \%$. O Gráfico 31 registrou o resultado obtido.

Gráfico 31 - Política para gestão de dados

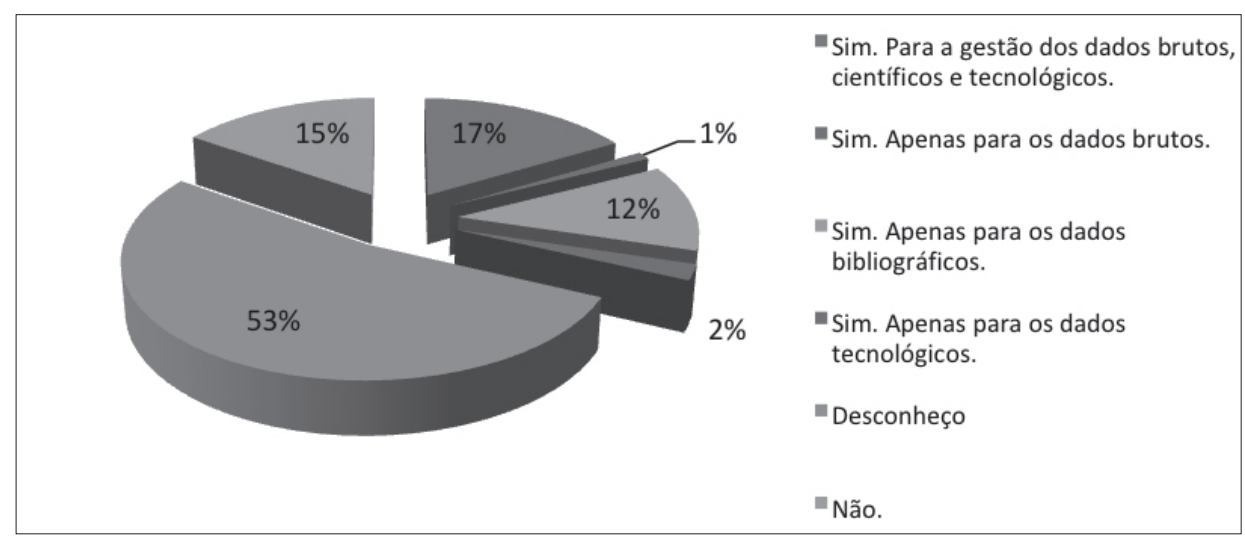

Fonte: Elaboração da autora. 
Os resultados foram coerentes por não existir uma infraestrutura que contemple esta questão, conforme os achados anteriores. Entretanto, esse resultado foi preocupante porque apesar de os INCTs não atuarem nos moldes do modelo e-Science, os pesquisadores que nele atuam desenvolvem pesquisa de alto nível e necessitam de um suporte para gerir e preservar o produto resultante das práticas realizadas.

A indicação da gestão dos dados, em sua plenitude, foi registrada apenas por $17 \%$ dos respondentes; dados bibliográficos (12\%); gestão dos dados tecnológicos (2\%); e parcela insignificante (1\%) para os dados brutos. Esses pontos requerem observação, tanto no que se refere aos produtos bibliográficos quanto aos tecnológicos, e especialmente os dados brutos, por se configurarem insumos passíveis de tratamento, curadoria e preservação. Principalmente por se tratarem de institutos com elevado índice de produção científica, justifica-se a preocupação com uma política que realize a gestão desses dados, obtidos como resultado do seu fazer científico. Os depoimentos obtidos com relação essa questão da gestão dos dados produzidos foram contemplados no Quadro 19.

Quadro 19 - Política para gestão dos dados de pesquisa

\section{POLÍTICA PARA GESTÃO DOS DADOS DE PESQUISA}

bom em relação aos resultados da pesquisa sim, quer dizer as publicações.... Nós temos arquivos e mantemos quais foram as publicações, quais foram os alunos que foram formados na formação de $\mathrm{RH}$ e como falei nós temos essa gestão dos dados a respeito das amostras. Os resultados que obtemos colocamos no gerenciador, digamos das amostras, dos nossos produtos. Poderíamos usar até mais... mas usamos. Nós temos essa política de gerenciamento.

é...isso nós já comentamos que nós disponibilizamos, divulgamos em nosso site. Basicamente isso, todo mundo sabe o que estamos produzindo com isso busca-se estimular a transformação dos livros.

[...] mas como as comunicações estão nos bancos de dados de nível alto, por exemplo, as sociedades científicas consolidadas, dificilmente essas sociedades serão quebradas. [... Suponho que eles tenham isso replicado algumas vezes.

[...] da mesma forma, tratamos essa informação da mesma forma que tratávamos a muito tempo, de uma forma não profissional. Chega ao final do ano compilamos todos os dados ou os dados mais importantes que foram adquiridos, dentro do INCT.[...]. Agora ter compilada e fazer gestão desse conhecimento são coisas bem distintas.

essa gestão não é feita, se você disser que teria interesse, é claro que teríamos interesse, interesse de alguém que inclusive mostrasse novos caminhos, a partir disso você poderia fazer isso e é impossivel você achar que você sabe tudo e pode fazer tudo. 
[...] basicamente o que nós fizemos foi o seguinte [...] nós conseguimos que o nosso site conversasse com o Lattes, para obter os dados do Lattes.

eu acho que respondendo a sua pergunta, do ponto de vista interno a dificuldade era assim, nos conseguirmos informações das pessoas, então por isso que no nosso caso conseguimos que o nosso site nos desse a informação das pessoas e por outro lado, pelo lado da administração, da coordenação dos INCTs eu acho que é uma verdadeira bagunça, com relação a essa gestão da base de dados.

Fonte: Elaboração da autora.

A e-Science surgiu de uma necessidade urgente de se enfrentar o "dilúvio de dados" e popularizou uma nova metodologia de pesquisa, desenvolvida em diferentes lugares, com uma história ainda imprecisa, denominações e grafias distintas, flexíveis e ainda tênues, mas com um objetivo comum, o uso de tecnologias de computação em rede para melhorar a colaboração e os métodos inovadores de investigação (WHITMIRE, 2013). A assertiva apresentada reforçou a percepção da convergência entre a tecnologia de computação, e as práticas colaborativas para inovação utilizadas no fazer científico.

Entretanto, esta metodologia de pesquisa não foi identificada nas práticas colaborativas realizadas pelos pesquisadores dos INCTs de Nanotecnologia, conforme os resultados atestaram. A gestão dos dados de pesquisa nos moldes dessa metodologia, a qual é uma das atividades contempladas pelo aparato tecnológico disponibilizado pela infraestrutura da $e$-Science, muito menos.

Identificou-se comportamentos distintos nos INCTs relacionados a gestão ds dados de pesquisa. Existem coordenações que procuram dar um tratamento aos dados produzidos, mesmo de forma rudimentar, apesar de terem consciência da necessidade de um tratamento especializado. Não o fazem, entretanto, por motivos diversos, dentre eles a inexistência de pessoal qualificado para essa tarefa e pelo fato de a gestão desses dados não ser o foco central de preocupação do instituto.

Algumas coordenações fazem a gestão dos dados de modo mais qualificado. Entretanto, não têm consciência de que estão realizando esta atividade. Algumas coordenações, a despeito de considerarem que estão tratando os dados, fazem-no de modo impróprio. Acreditam estarem protegidos contra perdas 
futuras por estarem vinculados a instituições, as quais teoricamente deveriam contemplar uma política de gestão dos dados produzidos.

Ao se concluir que os INCTs não realizavam uma política que contemplasse a gestão dos dados de pesquisa produzidos, nos moldes da e-Science, apesar de terem conhecimento, em parte, dessa necessidade, buscou-se identificar qual era a utilização dos dados brutos de pesquisa ou dos resultados obtidos. Os depoimentos dos coordenadores os contemplou.

[...] nós utilizamos os dados também, os dados da pesquisa. Por exemplo, nós fazemos umas medidas elétricas, medidas óticas e esses resultados estão disponíveis, todo mundo pode pegar;

[...] esses projetos centrais eles tem continuidade o tempo todo [...] Ou seja, a partir da informação um, que foi o desenvolvimento da nano, nós vamos buscando, cercando tudo que possa se relacionar com aquilo. Então tem coisas que começaram antes do INCT e ainda continuamos fazendo até hoje;

[...] então as pessoas fazem artigos e os artigos com seus resultados. Os resultados nunca são apresentados na forma de relatórios sempre é na forma de artigos.

Os relatos apresentados retrataram um grupo, o qual dentro das suas possibilidades aproveitam os dados brutos de pesquisa. Entretando, precisam submetê-los ao tratamento adequado para um reaproveitamento satisfatório por parte dos pesquisadores dos INCTs e disponibilizá-los a outros pesquisadores que demonstrem interesse. O destino atribuído aos dados configura-se em um problema sinalizado por Gray e Szalay (2007) quando ele observa que "um dos problemas é que todo projeto acaba num certo ponto e não está claro o que acontece com os dados."

Finaliza-se a apresentação dos dados pertinentes à manutenção de uma infraestrutura e suporte para os dados produzidos de pesquisa; o questionamento recaiu sob a atuação das agências de fomento. Os resultados foram contemplados no Gráfico 32. 
Gráfico 32 - Agências de fomento - Atuação

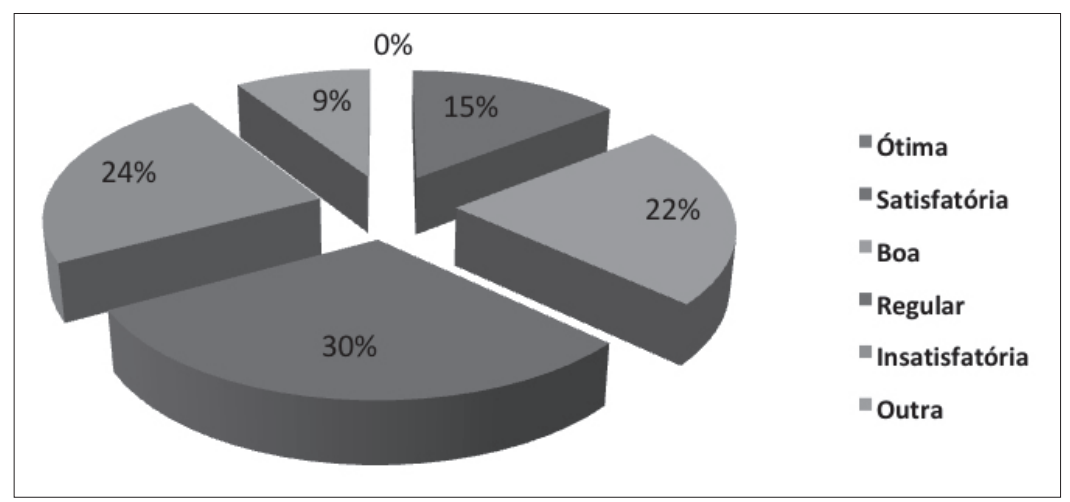

Fonte: Elaboração da autora.

Os resultados representaram que a atuação das agências de fomento não é satisfatória, ao menos no que diz respeito à infraestrutura de pesquisa, opinião correspondente a $30 \%$ das respostas obtidas, a qual evidencia a necessidade de mudanças nessa direção. $\mathrm{O}$ trabalho a ser feito é muito grande e o fornecimento efetivo de um arcabouço financeiro e tecnológico que satisfaça às reais necessidades dos pesquisadores e instituições associadas é premente

Os agentes de fomento que fazem parte da rede de práticas colaborativas para inovação dos INCTs de Nanotecnologia, possuem uma responsabilidade enorme que vai muito além do suporte financeiro. Os atores que desempenharam o papel de mediador, especialmente, ao atuarem de modo imprevisível e modificado no curso previsto nos acordos contemplados. A manutenção de atitudes, as quais primem pela pontualidade e constância no cumprimento dos acordos firmados serão bem acolhidas e certeza de metas cumpridas. Essa garantia favorecerá cada vez mais para que as políticas públicas voltadas para a CT\&I obtenham êxito.

Atitudes desse porte contribuem para: continuidade das políticas públicas implementadas e certeza na obtenção de um percentual de aprovação, o qual atinja até mais do que os 30\% resultantes de uma boa atuação; os agentes de fomento interferido favoravelmente na manutenção das políticas públicas como garantia no alcance de margens mais significativas de benefícios para todos os envolvidos na parceria; 
As políticas públicas voltadas para o fomento à CT\&I no Brasil são muito importantes para o desenvolvimento das pesquisas; para a o fornecimento de recursos e manutenção de suporte e infraestrutura; para a formação de recursos humanos e incentivo à transferência de conhecimento e tecnologia. Contudo, o cenário científico está repleto de controvérsias resultantes de tomadas de decisões e ações conflitantes em alguns momentos, a exemplo de: as agências de fomento que incentivam a colaboração, mas propiciam, ao mesmo tempo, a disputa por uma produção mais representativa entre os pesquisadores em termos qualitativos individuais; incentivam a colaboração, mas exigem que alguns comitês sejam compostos por pesquisadores exclusivamente de áreas específicas.

O comportamento dos diversos atores/actantes que interagem nesse contexto de práticas colaborativas representam as forças e conflitos em atuação. Os depoimentos dos coordenadores permitiram entender um pouco mais sobre a visão que possuem sobre as políticas públicas e sua repercussão nos INCTs de Nanotecnologia. Os resultados obtidos foram apresentados no Quadro 20.

Quadro 20 - Políticas Públicas - Relevância

\section{POLÍTICAS PÚBLICAS}

bom eu discordo um pouco... eu acho que no caso particular do meu INCT a política funcionou... Eu, na realidade, para falar a verdade eu acho que não funcionou [...] Até agora funcionou como qualquer outra iniciativa anterior do governo, porque uma política pública, no sentido do termo política pública, para mim é uma coisa de longo prazo que você investe na manutenção de um modelo e isso na realidade não foi feito.

eu não vejo o INCT como uma política pública porque se fosse uma política pública teria uma continuidade e é uma coisa que na vida inteira eu não vejo nenhuma diferença. Você faz um projeto grande, um grande investimento como foi feito anteriormente no PRONEC, depois teve os Institutos do Milênio etc e dá um grande volume de recursos, todo mundo fica feliz, depois não tem mais recursos para manter o investimento inicial feito.

[...] antes tinha sim, nós tinhamos o, digamos o Instituto do Milênio com as duas fases anteriores, eles tiveram um Instituto do Milênio bem parecido com os INCTs, bom talvez com um vigor menor, pois aprendeu-se com os Institutos do Milênio. Um estímulo maior para formação de recursos humanos a passar, estimular a passar conhecimento para a sociedade e para os recursos humanos.

isso é uma pergunta meio complicada, o próprio INCT já é um política pública que faz com que as colaborações tenham um outro patamar. Patamar extremamente elevado. Isso eu concordo, por si já é uma política que faz isso acontecer. Agora não necessariamente todas as outras políticas públicas tenham a ver com melhorar essa política de colaboração dos INCTs certo? 
não precisa ficar investindo toda hora mas você tem que no mínimo manter o investimento feito. Não mantém nada e tudo fica obsoleto, depois vem um outro programa e daí você renasce das cinzas e a cada cinco ou seis anos você tem que renascer das cinzas e na realidade por enquanto, os INCT estão no mesmo barco.

[...] você diz, olha você tem que colaborar por um lado, mas por outro você faz com que o sistema não ..... olha colabore aqui, mas aqui você vai ser penalizado porque você está colaborando. Isso aqui vale para alguns CAs do CNPq também. O que é que eu estou querendo te dizer com isso é que algumas, a maioria das políticas públicas elas te forçam a fazer colaboração, mas algumas penalizam quando você está fazendo colaboração.

bom eu acho que são muito relevantes, eu acho que são extremamente relevantes.

[...] talvez de grupos individuais, não necessariamente do INCT, algumas sim, algumas ajudam bastante nessa política de colaboração, outras não necessariamente em relação aos INCT, outras.... Ai às vezes tem o problema de bipolaridade das políticas públicas brasileiras.

de fato você publicar artigo com quatro, cinco pessoas, e na nossa área é impossível você publicar com menos do que isso pelo menos, e você é penalizado porque você esta publicando com muitas pessoas, você está entendendo?

[...] a questão da bipolaridade, mas no geral eu acredito que sim, no geral eu acredito que no processo de avaliação as políticas são propositivas no sentido da colaboração mas as vezes no processo de avaliação sua ou da pós-graduação em que você está inserido você é penalizado pos isso. É uma coisa que o sistema teria que repensar, e isso acontece não por causa do CNPq ou da Capes mas acontece por causa de pessoas.

Fonte: Elaboração da autora.

A política pública, no que se refere aos INCTs, foi válida, entretanto, existem muitos pontos a serem corrigidos. Alguns elementos de contrevérsias foram sinalizados, dentre eles destacaram-se:

- a manutenção dos recursos fornecidos;

- a continuidade dos programas implementados;

- as contradições entre incentivo à colaboração e punição por produção não condizente com os critérios estabelecidos pelas agências de fomento e pontuado como bipolaridade das políticas públicas;

- políticas propositivas no que se refere à colaboração mas penalizantes nas avaliações individuais e/ou dos programas de pós-grraduação.

Infere-se, entretanto, que apesar dos pontos de insatisfação apontados e passíveis de solução, a política pública representada pelo Programa INCT vem cumprindo o que foi planejado e conseguindo avanços referentes à pesquisa, formação de recursos humanos e transferência de conhecimento científico e tecno- 
lógico. A infraestrutura fornecida pelos INCTs, apesar de não estar alinhada ao modelo de infraestrutura $e$-Science, está cumprindo com o seu papel de suporte para a realização das pesquisas científicas e tecnológicas envolvidas no seu conglomerado.

O Programa INCT está interferindo de modo significativo nos resultados da produção científica nacional, com impacto quantitativo e qualitativo. A colaboração realizada entre os pesquisadores foi até utilizada como moeda de troca entre esses e as instituições sede. Conforme se pode constatar, a seguir, no relato dos coordenadores sobre a questão:

impactou não só do ponto de vista quantitativo, mas do ponto de vista qualitativo também. $\mathrm{O}$ impacto quantitativo foi muito alto. Só para você ter uma ideia alguns colegas, por exemplo, [...], se você entra no Lattes deles antes do início do INCT, são ex-alunos nossos que foram para lá, se você entra no Lattes deles antes vê pouquíssimas publicações e não tinham publicação, depois que foram para lá. Quando nós começamos os INCT você pega a publicação deles e eles publicam pelo menos dois, três artigos por ano. Seria muito difíil eles fazerem isso sem o INCT;

fora que abriu outras oportunidades, o fato deles estarem no INCT, por exemplo, os colegas do [...], eles usaram isso como moeda junto a universidade. Nós precisamos de laboratórios e a universidade construiu laboratórios para eles, conseguiu emendas parlamentares para colocar recursos dentro do laboratório, ou seja, é uma bola de neve, só tende a favorecer todo mundo;

claro que tem grupos que não cumprem o que prometem infelizmente, mas a grande maioria sim, a grande maioria veste a camisa e as coisas dão muito certo para todo mundo.

E, apesar dos problemas detectados, pertinentes às políticas de governo, que sofrem com as constantes interrupções em virtude das troca de forças dominantes no poder e quebra de continuidade dos programas implementados, por alguns governantes que assumiram os novos mandatos, estão conseguindo sobreviver. A questão que cercou a incerteza sobre a continuidade do Programa INCT foi uma das causas de preocupação dos coordenadores dos institutos analisados, cujos depoimentos foram registrados em algumas passagens desta seção. Observações direcionadas às questões particulares, que cercam toda problemática foram alvo de novos relatos dos coordenadores, conforme relatos apresentados no Quadro 21. 
Quadro 21 - Panorama político - INCTs

\begin{tabular}{|l|}
\hline \multicolumn{1}{|c|}{ PANORAMA POLíTICO - INCTs } \\
\hline [...] a verdade é que este governo atual tem sido bastante negativo para os INCTs. Você vê que \\
no governo do Lula por exemplo, eu não sei se por conjuntura ou por ser uma política própria, \\
os INCTs foram muito apoiados, mas nos quatro últimos anos e agora no novo governo da \\
Dilma, ela desprezou completamente os INCTs, espero que haja alguma mudança no novo \\
edital, mas o edital era para ser julgado em 2015, mas já foi empurrado para 2016.
\end{tabular}

[...] eu não vejo o INCT como uma política pública porque se fosse uma política pública teria tipo uma continuidade e uma coisa que na vida inteira eu não vejo nenhuma diferença, você faz um projeto grande, um grande investimento como foi feito anteriormente no PRONEC, depois teve os Institutos do Milênio etc e da um grande volume de recursos, todo mundo fica feliz, depois não tem mais recursos para manter o investimento inicial feito. Não precisa ficar investindo toda hora, mas você tem que no mínimo manter o investimento que foi feito. Não mantém nada e tudo fica obsoleto, depois vem um outro programa e dai você renasce das cinzas e a cada cinco ou seis anos você tem que renascer das cinzas e na realidade por enquanto, os INCT estão no mesmo barco.

claro, definitivamente, e nos diminuímos é uma questão de visão muito restrita dos nossos governantes. E não é desse governante ou daquele governante, é no geral mesmo, no geral. Eu não sei se eu deveria falar isso, mas eu só vi um governante que levou muito a sério e que acreditava, foi o governo Lula e, veja bem, não foi o PT não foi o governo Lula. É diferente e do meu ponto de vista são duas coisas bem distintas, porque no governo Dilma..., no governo Lula ele nunca rifou a Ciência e Tecnologia ele sempre colocou pessoas sérias. No governo Dilma ela já entrou colocando o Mercadante como ministro da Ciência e Tecnologia, é rifar mesmo e por aí você vê que isso é uma questão de prioridade, você não acha que aquilo é uma coisa importante, apesar do discurso certo, tem o discurso, mas a prática está....

uma política pública, o sentido do termo política publica para mim é uma coisa de longo prazo que você investe na manutenção de um modelo e isso na realidade não foi feito, tanto não foi feito que o dinheiro dos INCT terminaram foi, solicitada projetos novos para renovação ou novos para criação de novos INCT e na realidade a mais de um ano que estão adiando, adiando e adiando e sabe Deus quando que de fato vai ter recursos.

Fonte: Elaboração da autora.

Um cenário conturbado e recheado de incertezas em relação à perpetuação de uma política pública, que em termos de resultados efetivos e correspondência às exigências realizadas foi plenamente satisfeito. O Programa INCT publicou o resultados das chamadas realizadas e ofereceu aos seus associados um motivo para 
respirar com um pouco mais de tranquilidade e ter esperança na continuidade de um empreendimento de peso, que somente o tempo poderá atestar o desfecho.

As evidências que comprovaram as práticas colaborativas, a produção científica e a causalidade da $e$-Science como modelo de fomento para as pesquisas no Brasil foram contempladas na seção seguinte. 


\section{EVIDÊNCIAS DE PRÁTICAS COLABORATIVAS, PRODUÇÃO CIENTÍFICA E E-SCIENCE}

Identificar a evidência de práticas colaborativas e produção científica nos institutos investigados e a repercussão da $e$-Science enquanto modelo de fomento para pesquisas no Brasil. Esse foi o quinto e último objetivo específico da pesquisa. Chegar a esta etapa representou um longo percurso por caminhos trilhados, não sem dificuldade, mas carregados de surpresas e resultados que agregaram subsídios para a resposta adequada aos questionamentos da pesquisa.

Os resultados obtidos, ao longo da pesquisa se consolidaram na fonte para identificação das evidências supostas e a existência das práticas colaborativas para inovação realizadas nos INCTs de Nanotecnologia foi confirmada. Os relatórios de acompanhamento de projeto, o questionário e a entrevista online forneceram como resultados as práticas assinaladas e os indícios potenciais de sua real existência:

- atividades de P\&D;

- apoio na realização de eventos, programas e infraestrutura para apresentação de palestras, conferências, colóquios, simpósios etc.;

- colaboração científica;

- compartilhamento de recursos;

- formação e capacitação de recursos humanos; 
- prestação de serviços;

- negociações para obtenção de fomento.

As atividades de P\&D realizadas nos INCTs analisados foram consideradas como "atividades de natureza criativa e empreendedora, desenvolvidas sistematicamente, com vistas à geração de novos conhecimentos ou aplicação inovadora de conhecimento existente, inclusive para investigação de novas aplicações.” (MARTINS, 2011, p. 1). As categorias que especificaram estas atividades foram discriminadas como:

Pesquisa básica: trabalho experimental ou teórico realizado primordialmente para adquirir novos conhecimentos sobre os fundamentos de fatos ou fenômenos observáveis, sem o propósito de qualquer aplicação ou utilização;

Pesquisa aplicada: investigação original, realizada com a finalidade de obter novos conhecimentos, mas dirigida, primordialmente, a um objetivo prático;

Desenvolvimento experimental: trabalho sistemático, apoiado no conhecimento existente, adquirido por pesquisas ou pela experiência prática, dirigido para a produção de novos materiais, produtos ou equipamentos, para a instalação de novos processos, sistemas ou serviços, ou para melhorar substancialmente aqueles já produzidos ou instalados (OECD, 2013; RIZZATO et al., 2015, grifo nosso).

As empresas corresponderam à maioria dos atores/actantes que realizaram atividades de $\mathrm{P} \& \mathrm{D}$ com os INCTs analisados e representaram o percentual de 98\%. Além das empresas, instituições também foram agentes de interações em atividades de $\mathrm{P} \& \mathrm{D}$ com os INCTs. Contudo, compuseram o total pouco representativo de apenas $2 \%$. O Gráfico 33 ilustrou o resultado obtido. 
Gráfico 33 - Atividades de P\&D - Atores

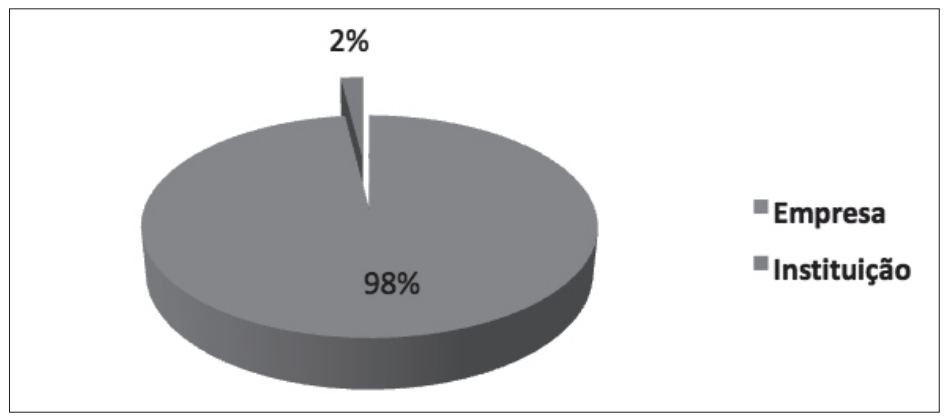

Fonte: Elaboração da autora.

A pesquisa aplicada e o desenvolvimento experimental caracterizaram as principais colaborações realizadas pelos institutos. Em termos de alcance geográfico, esses correspondiam a $82 \%$ de origem nacional e $18 \%$ de origem estrangeira. A dimensão jurídica correspondente a esses atores/actantes foi contemplada no Gráfico 34.

Gráfico 34 - Atividades de P\&D - Dimensão Jurídica

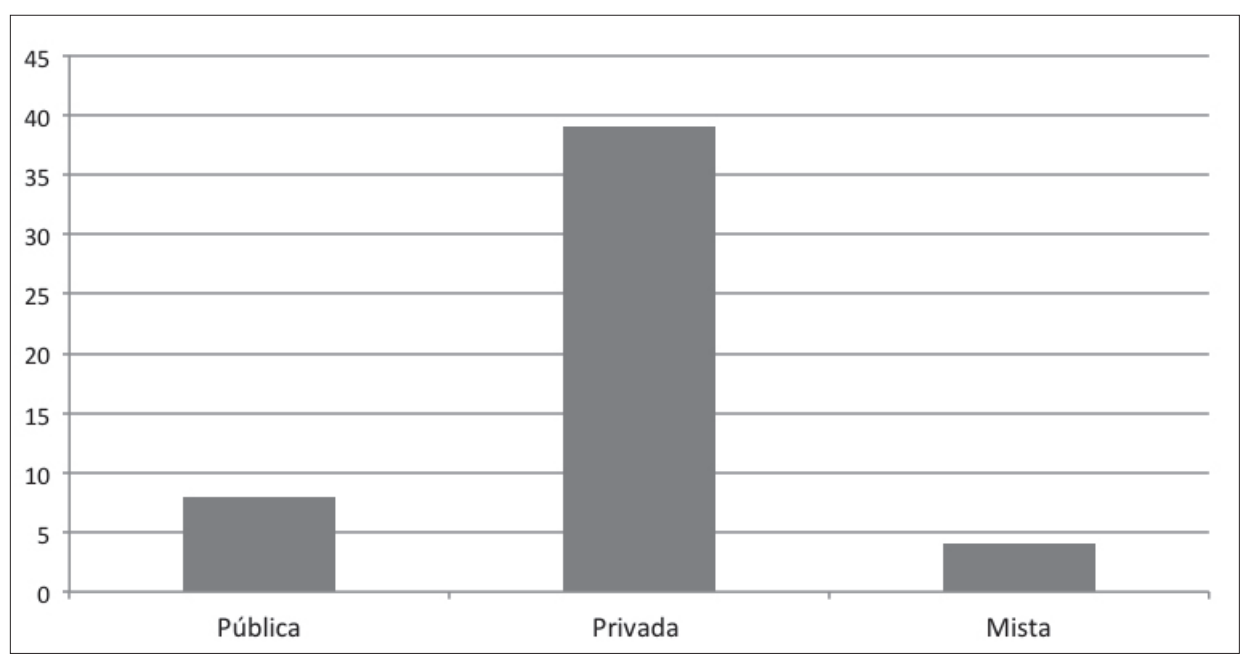

Fonte: Elaboração da autora. 
Os resultados sinalizados direcionaram para um cenário, em que se percebe o predomínio da atuação das empresas nacionais, nas interações realizadas. A presença das empresas privadas também foi registrada com o percentual de $75,51 \%$. Esse foi um ponto favorável considerando-se o terceiro objetivo do Programa INCT, o qual incentiva o desenvolvimento "de pesquisa científica e tecnológica de ponta associada a aplicações, promovendo a inovação e o espírito empreendedor, em estreita articulação com empresas inovadoras, nas áreas do Sistema Brasileiro de Tecnologia (Sibratec).” (PROGRAMA, 2008, p. 3).

O NAMITEC foi o instituto no qual se identificou o predomínio de atividades de $\mathrm{P} \& \mathrm{D}$ em relação aos demais institutos da área de Nanotecnologia analisados. O Gráfico 35 apresentou a distinção sinalizada.

\section{Gráfico 35 -Atividades de P\&D - INCTs}

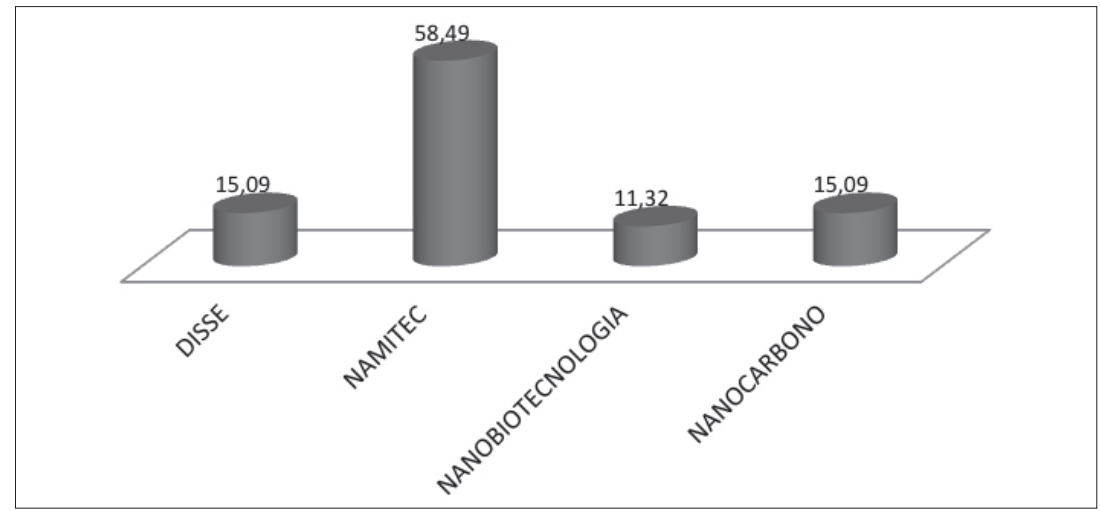

Fonte: Elaboração da autora.

Esse resultado era esperado dentro das convergências que caracterizam o grupo em análise. O conjunto de práticas e aplicações que o NAMITEC $(58,49 \%)$ realizou e foram apresentadas ao longo da pesquisa justificaram o destaque obtido. Os demais institutos, apesar de não terem apresentado uma inserção significativa no segmento pontuado, apresentam indícios de iniciativas nesta frente de atuação.

As práticas colaborativas que corresponderam ao apoio na organização de eventos, programas e infraestrutura foram identificadas quando se assinalou o 
grande índice de atividades desenvolvidas para difusão da ciência. Tanto o apoio quanto a participação nessas atividades foram contempladas pelos pesquisadores dos INCTs. Um resumo dos eventos organizados e sua abrangência geográfica foram apresentados no Gráfico 36.

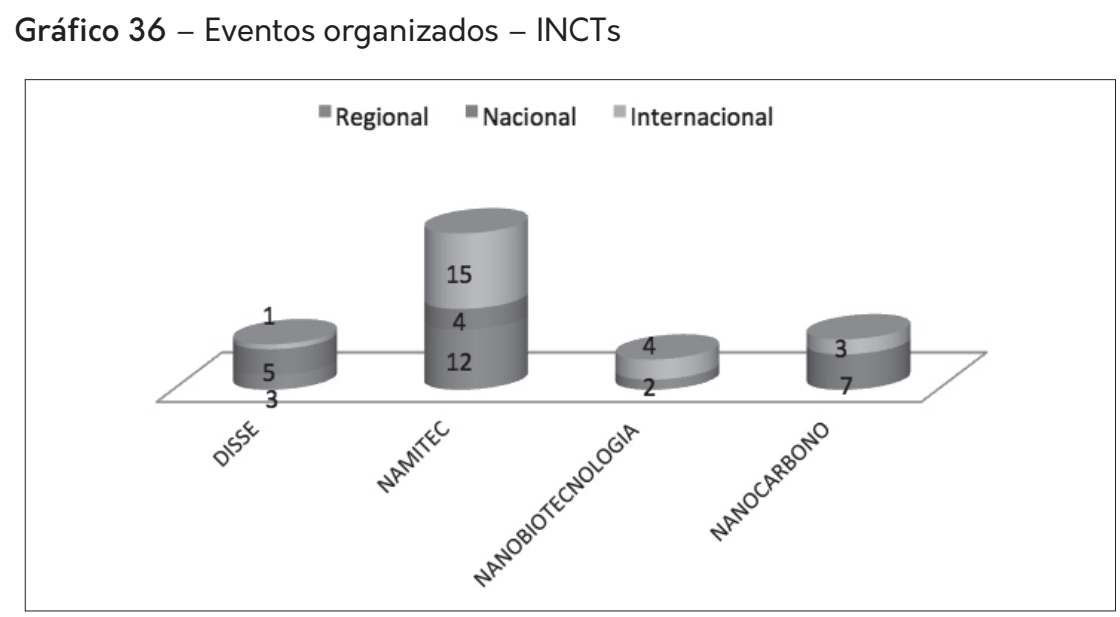

Fonte: Elaboração da autora.

A participação dos pesquisadores dos INCTs analisados, nos eventos constatou-se quando analisou-se a significativa produção em anais. As atividades específicas de colaboração científica, formação e capacitação de recursos humanos, realizadas pelos pesquisadores dos INCTs analisados, obtiveram índices expressivos que sinalizaram uma relação direta com a missão do Programa INCT.

Apresenta-se a rede identificada como resultado da colaboração científica realizada entre os pesquisadores dos INCTs de Nanotecnologia investigados, elas foram contempladas na Figura 12. Essa rede foi o resultado da coleta de dados da produção científica extraída com o software scriptLattes. Mais uma evidência comprovada da colaboração científica entre os pesquisadores dos INCTs de Nanotecnologia e dos resultados de sua produção científica.

A rede de colaboração científica dos pesquisadores dos INCTs de Nanotecnologia possui 237 nós e 600 arestas. Esses nós correspondem aos pesquisadores dos institutos que compuseram a amostra. O algoritmo de distribuição do software livre Gephi Fruchterman-Reingol foi utilizado mantendo-se o mesmo padrão 
das demais redes apresentadas. Cores utilizadas para se identificar os nós e assinalar a representatividade dos institutos na rede, conforme se segue: amarelo para o NAMITEC (44,96\%); verde para o NANOCARBONO (26,47\%); vermelho para o NANOBIOTECNOLOGIA (18,07\%); e rosa para o DISSE $(10,51 \%)$.

Figura 12 - Grafo da Rede de Colaboração Científica

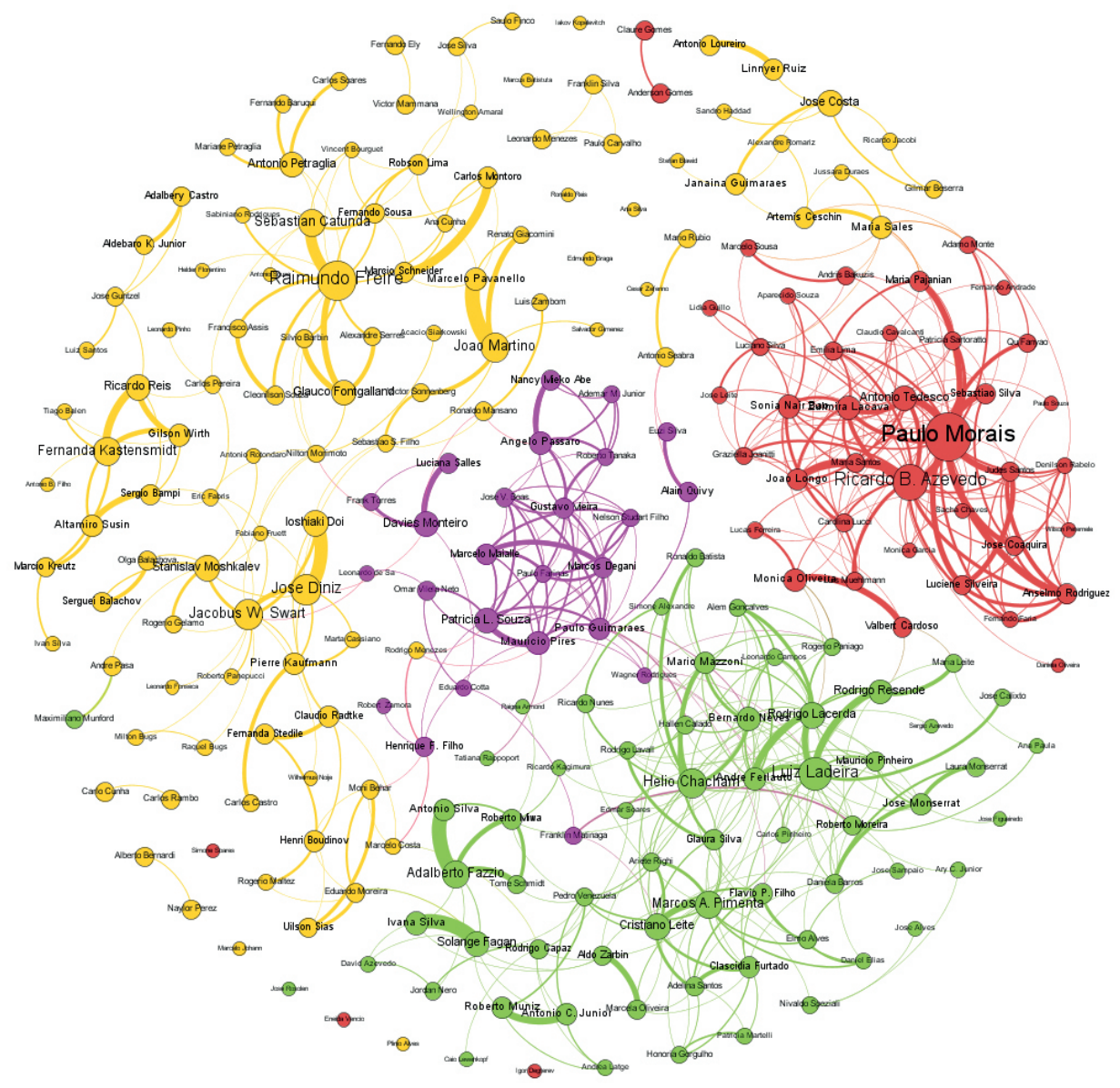

Fonte: Elaboração da autora.

A rede apresentou o grau médio correspondente a 2,521 e o grau ponderado médio de 8,987. A análise das conexões presentes não foi contemplada, por fugir dos objetivos pretendidos na pesquisa. Entretanto, identificou-se um campo re- 
pleto de interações que incitam à investigação mais detalhada e que poderá ser contemplada em estudos futuros.

As atividades de compartilhamento de recursos foram realizadas, em sua maioria, entre os INCTs e os laboratórios, esses últimos atores importantes e intermediários nas interações realizadas. Os resultados obtidos foram insumos de transformações realizadas em seu contexto. O Gráfico 37 contemplou a representação dos atores/actantes que caracterizaram esse tipo de prática colaborativa.

Gráfico 37 - Compartilhamento de Recursos - Atores/Actantes

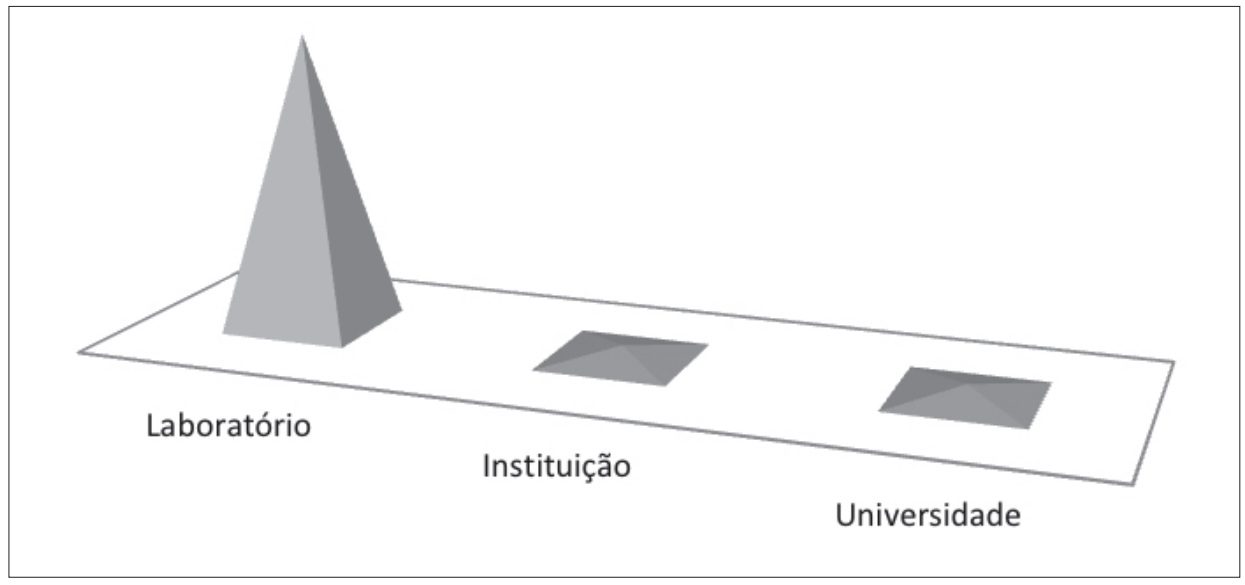

Fonte: Elaboração da autora.

A dimensão jurídica contemplada neste tipo de prática concentrou a maioria de atores na esfera pública com o percentual de $86,11 \%$. A esfera privada representou $8,33 \%$ e a militar, também identificada, 5,55\%. Esses percentuais sinalizam que, apesar da crise econômica que assola boa parte dos países no mundo e de todo desgaste que cerca as instituições públicas em geral no que concerne a restrições de gastos, essas ainda representam as mantenedoras das infraestruturas utilizadas pelos pesquisadores nos laboratórios em que realizam suas pesquisas.

É importante destacar que essa prática colaborativa pode ser realizada paralelamente a outras atividades que as representam. Contudo, os atores/actantes destacados foram os responsáveis pelo maior índice de interações que carac- 
terizaram compartilhamento de recursos e, desse modo foram contemplados. O Quadro 22 apresentou um recorte dos atores/actantes que realizaram dentre outras atividades, significativo compartilhamento de recursos com os INCTs analisados.

Quadro 22 - Compartilhamento de Recursos - Atores/Actantes

\begin{tabular}{|c|c|c|c|}
\hline Ator/Actante & Estrutura & Dimensão Jurídica & Alcance Geográfico \\
\hline Alcatel-Lucent's & Laboratório & pública & estrangeiro \\
\hline CCS & Laboratório & pública & nacional \\
\hline CNRNANO & Instituição & pública & estrangeiro \\
\hline CPP & Laboratório & pública & estrangeiro \\
\hline EMPA & Laboratório & privada & estrangeiro \\
\hline GQM & Laboratório & pública & nacional \\
\hline $\mathrm{HPL}$ & Laboratório & privada & estrangeiro \\
\hline IMEC & Laboratório & pública & estrangeiro \\
\hline ITU-T & Laboratório & pública & estrangeiro \\
\hline LabCri & Laboratório & pública & nacional \\
\hline LABDIS & Laboratório & pública & nacional \\
\hline LabMic & Laboratório & pública & nacional \\
\hline Lab-Nano & Laboratório & pública & nacional \\
\hline Laboratório Exército & Laboratório & militar & nacional \\
\hline Lab-Raman & Laboratório & pública & nacional \\
\hline LabSem & Laboratório & pública & nacional \\
\hline LANano & Laboratório & pública & nacional \\
\hline LASIMON & Laboratório & pública & nacional \\
\hline LCDS & Laboratório & militar & nacional \\
\hline LETI & Laboratório & pública & estrangeiro \\
\hline LN & Laboratório & pública & nacional \\
\hline LNLS & Laboratório & pública & nacional \\
\hline LNMS & Laboratório & pública & nacional \\
\hline LNS & Laboratório & pública & nacional \\
\hline LPD & Laboratório & pública & nacional \\
\hline LQN & Laboratório & pública & nacional \\
\hline LRM & Laboratório & pública & nacional \\
\hline NMG & Laboratório & privada & estrangeiro \\
\hline NNL & Laboratório & pública & estrangeiro \\
\hline Optima & Laboratório & pública & nacional \\
\hline OptMA Lab & Laboratório & pública & nacional \\
\hline
\end{tabular}




\begin{tabular}{|l|c|c|c|}
\hline Ator/Actante & Estrutura & Dimensão Jurídica & Alcance Geográfico \\
\hline OTC & Laboratório & pública & estrangeiro \\
\hline QUB & Universidade & pública & estrangeiro \\
\hline RBPINO & Laboratório & pública & nacional \\
\hline SRC & Laboratório & pública & estrangeiro \\
\hline Zentrum & Laboratório & pública & estrangeiro \\
\hline
\end{tabular}

Fonte: Elaboração da autora.

Entretanto, o quadro mudou quando o assunto foi a abrangência geográfica. Os laboratórios, instituições e universidades que fornecem seus equipamentos e instalações para a realização de práticas colaborativas estavam, na maioria, na esfera nacional com o percentual de $65 \%$, mas acompanhados significativamente pelos que se situavam no ambiente estrangeiro com 35\%. O Gráfico 38 representou os percentuais pontuados.

Gráfico 38 - Compartilhamento de recursos - Alcance geográfico

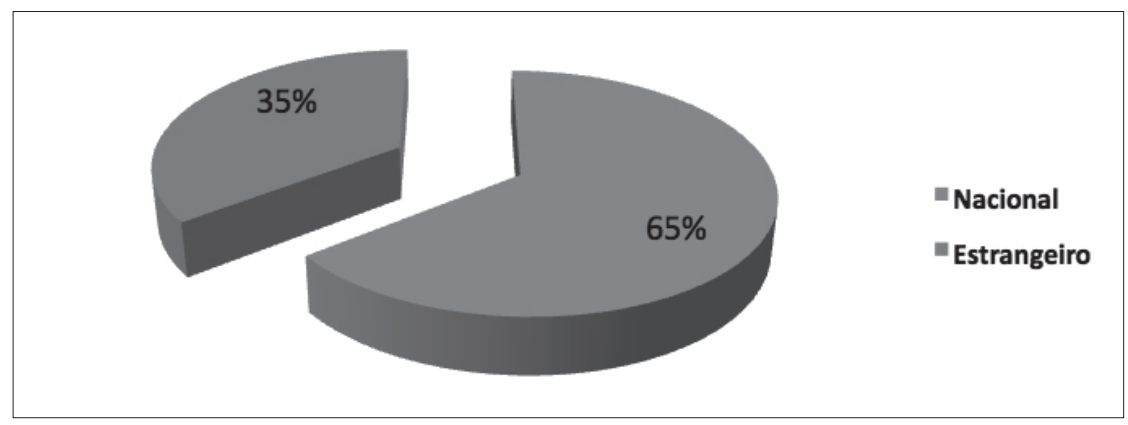

Fonte: Elaboração da autora.

Isso demonstrou que os pesquisadores, apesar de utilizarem os equipamentos existentes no país, cada vez mais estão partindo para conquistar parcerias com instituições, universidades e laboratórios no âmbito internacional. Conforme se comprovou com os resultados apresentados ao longo deste capítulo. Esse é um aspecto positivo, o qual enquadra-se dentro dos objetivos pretendidos pelo Programa INCT, por incentivar os pesquisadores dos institutos a buscarem esferas de fronteira para além do espaço nacional. 
O DISSE apresentou o maior percentual (34\%) de compartilhamento de recursos quando observado em comparação com os outros INCTs analisados. O Gráfico 39 ilustrou a prática observada.

Gráfico 39 - Compartilhamento de recursos - INCTs

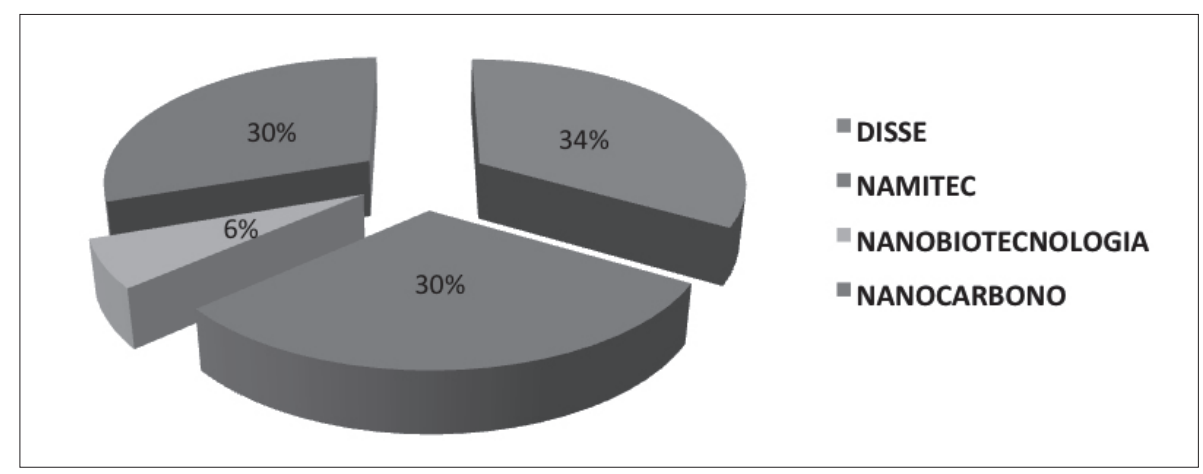

Fonte: Dados da pesquisa.

As atividades pertinentes à prestação de serviços como um resultado das parcerias colaborativas realizadas, podem ser identificadas conforme indicam Rizzato (2015) e a OCDE (2013) como:

- prestação de serviços tecnológicos como, ensaios e teste;

- consultorias diversas incluindo caracterização e diagnósticos;

- serviços de informação científica e técnica discriminados como:

- registro (desenvolvidas pelos serviços de marcas e patentes);

- coleta (desenvolvidas pelo quadro de funcionários científico e técnico);

- indexação (desenvolvidas pelos serviços de bibliografia);

- classificação (desenvolvidas pelos serviços de difusão de informação científica e técnica e os serviços de conselho);

- difusão (desenvolvidas pelas conferências científicas);

- tradução;

- análise;

- avaliação entre outras. 
Os resultados obtidos relacionados a essas práticas contemplaram uma baixa incidência de serviços prestados entre os institutos. Registraram-se apenas no NAMITEC e no DISSE, não se encontraram referências à realização dessa atividade nos demais institutos com essa denominação. Entretanto, constatou-se que os pesquisadores dos outros INCTs analisados realizaram registro de patentes, desenvolveram atividades de difusão técnico científica, participaram de conferências e eventos diversos. Contudo utilizaram outras denominações para designar a atividade, o que mascarou o resultado obtido.

As negociações para obtenção de fomento foi mais uma evidência das práticas colaborativas realizadas. Os recurso iniciais obtidos para implementar o Programa INCT foi um exemplo das diversas parcerias que podem ocorrer. Foram apresentados pela Tabela 5, e resgatada para ilustrar o exemplo dado.

Tabela 5 - Recursos financeiros - Implementação do Programa INCT

\begin{tabular}{c|c|c|c|c|c}
\hline \multicolumn{7}{c}{ RECURSOS FINANCEIROS (R\$ milhões) } \\
\hline FONTE & 2008 & 2009 & 2010 & TOTAL & $\%$ \\
\hline CNPq & $30.000 .000,00$ & $40.000 .000,00$ & $40.000 .000,00$ & $110.000 .000,00$ & 25,29 \\
\hline FNDCT & $40.000 .000,00$ & $60.000 .000,00$ & $60.000 .000,00$ & $160.000 .000,00$ & 36,78 \\
\hline CAPES & $30.000 .000,00$ & - & - & $30.000 .000,00$ & 6,90 \\
\hline FAPEMIG & $30.000 .000,00$ & - & - & $30.000 .000,00$ & 6,90 \\
\hline FAPERJ & $30.000 .000,00$ & - & - & $30.000 .000,00$ & 6,90 \\
\hline FAPESP & $75.000 .000,00$ & - & - & $75.000 .000,00$ & 17,24 \\
\hline TOTAL & $235.000 .000,00$ & $100.000 .000,00$ & $100.000 .000,00$ & $275.000 .000,00$ & 100 \\
\hline
\end{tabular}

Fonte: Adaptado do CNPq (2008).

No âmbito dos INCTs registraram-se outras parcerias que contemplavam negociações para obtenção de fomento. Dentre essas parcerias, foram identificadas as que favoreceram a captação de recursos para o DISSE e o NANOBIOTECNOLOGIA, recursos esses relacionados por tipo como: capital e custeio; manutenção (custeio); bolsas; equipamentos; acessórios; construção e infraestrutura, conforme o Quadro 23. 


\section{Quadro 23 - Captação de Recursos}

\begin{tabular}{|c|c|c|c|c|c|}
\hline \multicolumn{6}{|c|}{ CAPTAÇÃO DE RECURSOS } \\
\hline INCT & FONTE & TIPO & $\begin{array}{c}\text { VALOR } \\
\text { APORTADO RS }\end{array}$ & $\begin{array}{c}\text { VALOR } \\
\text { APORTADO } \\
\text { USS }\end{array}$ & $\begin{array}{c}\text { VALOR } \\
\text { APORTADO } €\end{array}$ \\
\hline \multirow{14}{*}{ DISSE } & FAPERJ & Capital e custeio & $180.000,00$ & & \\
\hline & Finep (01.10.0624.00) & Capital e custeio & $1.919 .607,11$ & & \\
\hline & Finep & Capital e custeio & $1.600 .000,00$ & & \\
\hline & Finep & Capital e custeio & $1.523 .638,00$ & & \\
\hline & Finep: Pró-Infra & Capital & $1.265 .000,00$ & & \\
\hline & CNPq - Universal & Capital e custeio & $39.360,00$ & & \\
\hline & CNPq & Capital e custeio & $781.329,54$ & & \\
\hline & CNPq: Casadinho & Capital e custeio & $250.000,00$ & & \\
\hline & FAPEMIG (2012) & $\begin{array}{l}\text { Manutenção } \\
\text { (custeio) }\end{array}$ & $66 k(2012)$ & & \\
\hline & FAPEMIG - PPM VI & Capital e custeio & $48.000,00$ & & \\
\hline & FAPEMIG & $\begin{array}{l}\text { Universal (capital } \\
\text { e custeio) }\end{array}$ & $\begin{array}{c}50 k(2010)+ \\
50 k(2012)\end{array}$ & & \\
\hline & $\begin{array}{l}\text { FAPEMIG Proc. APQ } \\
02235-11\end{array}$ & Capital e custeio & $45.150,00$ & & \\
\hline & $\begin{array}{l}\text { Capes: Pro-- } \\
\text { Equipamentos }\end{array}$ & Capital & $1.000 .000,00$ & & \\
\hline & FAPESP & Capital e custeio & $37.137,00$ & $55,941.25$ & \\
\hline \multirow{13}{*}{ NANOBIOTECNOLOGIA } & FAP-DF & $\begin{array}{l}\text { Capital, custeio e } \\
\text { bolsas }\end{array}$ & $1.599 .036,90$ & & \\
\hline & Capes & Bolsas e custeio & $1.003 .381,28$ & & \\
\hline & Capes & Bolsas e custeio & $2.075 .920,64$ & & \\
\hline & FAPEMIG & $\begin{array}{l}\text { Capital, custeio e } \\
\text { bolsas }\end{array}$ & $1.434 .734,00$ & & \\
\hline & $\begin{array}{l}\text { FP-7 - Comunidade } \\
\text { Europeia }\end{array}$ & $\begin{array}{c}\text { Bolsas (Marie } \\
\text { Curie 2012) }\end{array}$ & & & $\begin{array}{c}98.400,00(\text { Total } \\
\text { projeto: } 428.000,00)\end{array}$ \\
\hline & $\begin{array}{l}\text { FP-7 - Comunidade } \\
\text { Europeia }\end{array}$ & $\begin{array}{c}\text { Custeio (Large } \\
2013 \text { ) }\end{array}$ & & & $\begin{array}{c}296.000,00 \\
\text { (Total projeto: } \\
10.000 .000,00)\end{array}$ \\
\hline & $\begin{array}{l}\text { FP-7 - Comunidade } \\
\text { Europeia }\end{array}$ & $\begin{array}{l}\text { Bolsas (Marie } \\
\text { Curie 2013) }\end{array}$ & & & $65.000,00$ \\
\hline & $\begin{array}{l}\text { Programa INOVARS - } \\
\text { Sebrae }\end{array}$ & Bolsas e custeio & $320.000,00$ & & \\
\hline & RHAE & Bolsas & $174.600,00$ & & \\
\hline & RHAE & Bolsas & $233.000,00$ & & \\
\hline & Finep & Equipamentos & $2.226 .382,61$ & & \\
\hline & UFG & Acessórios & $350.000,00$ & & \\
\hline & UFG & $\begin{array}{l}\text { Construção e } \\
\text { infraestrutura }\end{array}$ & $120.000,00$ & & \\
\hline \multicolumn{3}{|c|}{ TOTAL } & $18.392 .277,08$ & $55,941.25$ & $\begin{array}{c}459.400,00 \text { (total do } \\
\text { projeto } 10.428 .000,00)\end{array}$ \\
\hline
\end{tabular}

Fonte: Elaborado pela autora. 
A apresentação dos dados da Tabela 18 evidenciaram que os INCTs analisados, em especial o DISSE e o NANOBIOTECNOLOGIA, estavam buscando fontes alternativas para manutenção de suas atividades. Essa é uma atitude louvável, considerando-se os atrasos e sobressaltos decorrentes do repasse irregular de verbas pelas agências de fomento mantenedoras do Programa INCT, para se tentar minimizar a falta de motivação e mobilização dos pesquisadores, conforme se registrou em relatos coletados nas entrevistas, em momentos de falta de recursos financeiros.

O modelo e-Science, por possuir elementos que o assemelhavam ao Programa INCT motivou a pesquisa e incitou a o aprofundamento na investigação. Essa foi uma tentativa de se identificar uma relação de causa e efeito entre os dois modelos, apesar de a palavra e-Science não estar assinalada na política pública dos INCTs escolhida para o estudo. As semelhanças identificadas direcionaram para a suposição de que o modelo $e$-Science poderia ser considerado como um modelo estruturante das atividades que fundamentavam os INCTs. Dentre as semelhanças identificadas entre as duas iniciativas se assinalou:

- aporte financeiro significativo da iniciativa pública;

- forte perfil colaborativo que favorecia o trabalho em rede e era o foco central das relações e conexões entre os pesquisadores;

- trabalho com tecnologia de ponta e característica de um aparato tecnológico mantenedor de uma infraestrutura e suporte para pesquisas revertidas em benefícios para a sociedade e empresas;

- atenção voltada para a inovação, científica e tecnológica.

Entretanto, a comprovação de um pressuposto com essa magnitude necessitava de elementos "robustos" que permitissem corroborar uma assertiva desse porte.

O Programa e-Science da FAPESP, como política pública de fomento para pesquisas no Brasil, voltada para projetos que envolviam a área de Computação, foi utilizada como parâmetro na análise. As primeiras atividades registradas oficialmente ocorreram de agosto a novembro de 2009, uma parceria que contemplou a realização de oficinas e foi implementada entre a FAPESP e a Ciência da 
Computação e Engenharia (CS\&E). As metas prioritárias contemplaram a identificação de novos rumos para a Ciência da Computação e a ajuda para o avanço de programas relevantes da FAPESP, com oportunidades para colaboração de pesquisas com a Ciência da Computação.

O fortalecimento da primeira iniciativa da FAPESP para inserção da temática sobre e-Science no país teve continuidade. Movimentos em torno da realização de eventos e lançamento de editais complementaram as atividades. Entretanto, sem subsídios consistentes que embasassem a prerrogativa, era prematuro associar o Programa e-Science, iniciado no Brasil efetivamente em 2013, com a política pública representada pelo Programa INCT, lançada em 2008 Especialmente devido às particularidades que os caracterizam, pois associações desse porte devem ser realizadas sob bases pertinentes.

As iniciativas que representam a $e$-Science no país são projetos novos e em vias de implementação e o Programa INCT possui uma atuação um pouco mais consolidada de oito anos. A base que fundamenta o Programa INCT foi apresentada ao longo da pesquisa realizada e sua meta estava voltada para o suporte à pesquisa, formação de recursos humanos, transferência de conhecimento para a sociedade e para o setor empresarial ou governo, conforme foi assinalado no edital de lançamento (CNPq, 2008).

O Programa e-Science, lançado pela FAPESP em 2013, tem como principal objetivo "encorajar abordagens novas, ousadas e não convencionais para pesquisa de ponta, multidisciplinar, integrando grupos de pesquisa em Computação e em outras áreas." (FAPESP, 2015). Entende-se, desse modo, que era pertinente a associação entre modelos de infraestrutura de pesquisa cobertos pela $e$-Science, práticas colaborativas e políticas de fomento à pesquisa em CT\&I. Observa-se, nesse conjunto, que $e$-Science é considerada a "base para a pesquisa colaborativa e em rede.” (IZIQUE, 2013, p. 2). Esse é um elemento importante para a realização do "experimento" que se define como fazer científico contemporâneo.

Associações entre a $e$-Science e a área da Nanotecnologia foram identificadas na literatura. Em relatório realizado pela Lloyd's Register Foundation (LR) em 2004, encontrava-se a indicação de que "a Nanotecnologia terá um grande impacto sobre quase todos os setores incluindo, energia, transporte, fabricação, medicina, tecnologia da informação e telecomunicações. Sua associação com os Big Data 
é frequente ao passo dessa parceria ser denominada como a próxima revolução digital." (RODRIGUEZ, 2015).

Contudo, os resultados convergiram para a inexistência de uma associação entre o modelo e-Science e o Programa INCT nos institutos investigados. Esse modelo não é estruturante das práticas colaborativas realizadas entre os pesquisadores dos institutos da área de Nanotecnologia investigados, conforme depoimento dos coordenadores entrevistados e confronto dos dados coletados na pesquisa, apresentados em vários momentos deste capítulo.

Os coordenadores quando questionados sobre o interesse em participar de iniciativas voltadas para a e-Science, afirmaram que se fazia necessário maior entendimento sobre a temática para poderem engajar-se em projetos a ela relacionados. O interesse na iniciativa foi descartado a princípio, mas depois afirmaram que com o fornecimento de uma infraestrutura adequada poderiam até pensar em participar dos projetos que cobriam a chamada da FAPESP. Trechos dos depoimentos foram apresentados logo a seguir:

[...] eu acho que nós não temos interesse em participar. Certo, eu preciso na verdade me familiarizar para entender melhor o que quer dizer, para ver se sentimos interesse;

interesse.... não sei se nós temos é competência para participar do processo, interesse nós sempre temos, mas a questão é competência. E não sei também se nós não vamos fugir tanto do escopo..... O problema é que somos sempre poucos para fazer muitas coisas;

[...] se houvesse uma coisa organizada, uma ferramenta organizada, seria útil sim.

[...] Basicamente você tem que pensar que nós cientistas, nós não temos esse tempo para fazer essas coisas, cada um está em seu laboratório fazendo suas pesquisas, mas se nós tivéssemos acesso a uma ferramenta bem feita isso seria bastante útil.

nós poderíamos até tentar, o problema é você ver ..... de que forma isso seria feito por exemplo, se fosse fazer hoje, não teria pessoal disponivel. Porque para uma coisa dessas ir adiante, bem feita... precisa ter pessoas dedicadas a isso. Teria que ter pessoas para chamar para fazer o projeto. Atualmente eu não tenho recursos financeiros, nem humanos disponiveis para fazer isso, mas tendo isso seria de interesse sim. 
Os depoimentos dos coordenadores reforçou a suposição de que a temática e-Science, na realidade é pouco conhecida e difundida no ambiente de atuação dos pesquisadores dos INCTs de Nanotecnologia investigados. Entretanto, causou interesse entre os coordenadores. por se tratar de iniciativas que poderiam trazer benefícios e conquista de desafios inovadores no aspecto científico. Apesar do modelo e-Science não ser estruturante das práticas colaborativas desses pesquisadores, no momento, nada impede de tornar-se no futuro. 


\section{CONCLUSÃO}

Talvez não tenhamos conseguido fazer o melhor, mas lutamos para que o melhor fosse feito. Não somos o que devemos ser, não somos o que iremos ser.... Mas graças a Deus, não somos o que éramos.

(Martin Luther King Jr.)

Conclui-se que a evidência contemporânea da transitoriedade das práticas colaborativas tradicionais, potencializadas pela utilização dos artefatos tecnológicos contemporâneos, repercutem positivamente na produção científica, no estabelecimento e na solidificação das redes colaborativas para inovação dos pesquisadores dos INCTs da área de Nanotenologia investigados.

A política pública ensejada no modelo dos INCTs revelou sinergia com os propósitos dos centros de pesquisas internacionais estruturados em torno da noção de e-Science. Contudo, a ausência explícita do conceito no âmbito das diretivas públicas brasileiras, a descontinuidade das políticas e recursos dedicados impediram a articulação científica formal entre os modelos.

Nota-se que o modelo e-Science, com todo seu potencial tecnológico, ainda não está plenamente inserido em contextos que trabalham e produzem tecnologia de ponta, como os INCTs da área de Nanotecnologia. Nesses ambientes ainda predominam recursos tradicionais na condução de projetos científicos. Assinala-se que os pesquisadores desenvolvem suas atividades científicas em ambien- 
tes colaborativos digitais menos complexos, sem necessariamente acionar e/ou manter grandes arsenais de dados em colaboração com outros centros nacionais ou internacionais de pesquisa. Pelo menos, a infraestrutura identificada não contemplou a existência de um centro de processamento de dados responsável pela captura, curadoria e análise de grandes volumes de dados brutos e informação científica e tecnológica característicos dessa infraestrutura, muito menos os pesquisadores afirmaram desenvolver prioritariamente suas atividades científicas em ambientes colaborativos digitais.

Atividades realizadas com artefatos digitais provenientes de ambientes colaborativos não condicionaram a tônica predominante das práticas realizadas, conclusão preocupante para uma área que é considerada como um grande filão de desenvolvimento social, econômico e estratégico de um país. Como conceber que os institutos em questão não estejam inseridos nesse contexto que lhes traria instrumentos para inserção em outros países mais efetivamente e condições de interação com outros pesquisadores nos mais longínquos recantos do mundo. Essas são questões que políticas públicas consideradas como articuladoras e propositivas podem começar a reverter.

Contudo, apesar de o modelo $e$-Science não ser estruturante das práticas colaborativas para inovação desses pesquisadores no momento, não há impedimento de que assim venha a se tornar no futuro. O contexto em que foi desenvolvida a pesquisa representada pela $e$-Science, a curiosidade inicial e incentivo para a realização de uma investigação de porte; as práticas científicas colaborativas para inovação, o elo e pressuposto que caracterizaram as interações representadas pelas redes; as políticas públicas, o mantenedor e agente maior de fomento para as parcerias realizadas, contempladas pelos INCTs; e a área de Nanotecnologia, uma grata escolha no percurso, representaram o quanto pesquisas que agregam temas relevantes e contemporâneos podem contribuir para a comunidade científica. A área da Nanotecnologia apresentou peculiaridades só identificadas com o esforço empreendido na pesquisa.

A busca pelo entendimento desses termos e conceitos, carregados de subjetividades e incorpados por um poder revolucionário, foi o sinal de alerta de que o conhecimento a eles pertinente precisava vir à tona. O retorno obtido confirmou esta suposição e está sendo deixado como contribuição de um esforço 
intenso de pesquisa. $\mathrm{O}$ conhecimento foi incorporado ao contexto de pesquisas realizadas pela Ciência da Informação e inserido na agenda correspondente a questões contemporâneas que cercam a área.

Constatou-se que a associação entre as práticas colaborativas para inovação e políticas públicas repercutiu positivamente na produção científica dos pesquisadores e na formação de redes formais e informais de pesquisadores da área de Nanotecnologia.

Conclui-se que a interferência positiva das práticas colaborativas para inovação na produção científica dos pesquisadores dos institutos da área de Nanotecnologia ressaltou a pertinência de políticas públicas que incentivem e financiem iniciativas realizadas em redes colaborativas. Os ganhos na produção científica certamente serão surpreendentes e um resultado com essa perspectiva favorecerá o desenvolvimento do país e a inserção em novos horizontes.

A formação de recursos humanos, uma das práticas colaborativas para inovação identificadas, foi grata surpresa para a pesquisadora mas pertinente ao contexto. Identificá-la como meta do Programa INCT e comprovar sua efetiva execução como bandeira empunhada pelos INCTs de Nanotecnologia foi o sinal da valorização do capital humano, tão importante para conquistas nas quais a educação de um país faz muita diferença, favorece a inserção internacional e serve como um aporte para o desenvolvimento global da sociedade. Esse resultado foi inesperado, mas comtemplado com satisfação.

A colaboração científica tradicional esteve presente de modo efetivo nas atividades dos pesquisadores dos INCTs de Nanotecnologia, a evidenciar que a tradição ainda prevalece fortemente, apesar das inovações tecnológicas que ocorrem na sociedade contemporânea e da inserção de novas práticas colaborativas no âmbito acadêmico. Os resultados obtidos ao longo da pesquisa foram testemunhos da presença de uma prática tradicional, apesar do avanço tecnológico característico da contemporaneidade.

Os ganhos obtidos com a formação em redes colaborativas e o alto índice de produtividade dos pesquisadores dos INCTs de Nanotecnologia analisados não se caracterizam apenas em termos quantitativos. Os benefícios qualitativos obtidos foram contemplados com a forte inserção internacional dos pesquisadores da área analisada em países como Alemanha, Estados Unidos, 
Inglaterra, Holanda, China, Suíça e muitos outros nos mais longínquos recantos do mundo.

A implementação dos INCTs favoreceu e solidificou as redes de pesquisadores existentes e que atuavam em áreas correlatas à Nanotecnologia e foi considerada como a continuidade de ações que eram realizadas antes de sua criação. O modelo INCT foi um estímulo extra para os pesquisadores, oportunidade de abertura de novas frentes de pesquisa com a multidisciplinaridade contemplada e uma possibilidade de avanço significativo em áreas antes não contempladas. Novas redes colaborativas também foram constituídas, e os saldos para um programa dessa magnitude foi positivo e a inovação presente no desenvolvimento de novos dispositivos tornou-se uma realidade. Foram vários os aspectos citados que direcionaram para essa assertiva, dentre os quais foram indicados: agregação de pesquisadores com atividades correlatas; agregação de pesquisadores com especialidades distintas; agregação de pesquisadores de instituições diversas do país; maior avanço na pesquisa, especialmente em áreas antes não contempladas; agregação de conhecimentos afins e competências de diferentes instituições; otimização de recurso; fortalecimento na formação de recursos humanos; desenvolvimento de tecnologia inovadora; e fortalecimento do trabalho em redes colaborativas.

A identificação da infraestrutura existente nos INCT ajudou a entender o porquê de pesquisadores que, em sua maioria, atuam com elementos da alta tecnologia não realizarem projetos nos moldes $e$-Science. Os pesquisadores da área em investigação não são totalmente leigos em relação ao termo $e$-Science, o que se justifica por se tratar de uma área que inclui, em seu conjunto, profissionais com um perfil que indica competência no trato com as tecnologias de informação e comunicação e estão bem informados sobre as inovações da área. Apesar disso, uma parcela significativa $(19,8 \%)$ de pesquisadores ainda desconhece o termo, o que também se justifica pela multidisciplinaridade característica da área, a qual contempla profissionais que atuam em outras frentes de ação, utilizam alta tecnologia, mas essa não é objeto de discussão nem estudo.

A movimentação em torno de artefatos e insumos característicos da atividade científica contemporânea pressupõe um fazer científico diferenciado e com características próprias, o que permite corroborar a assertiva de que metodologias 
e fazeres estão se adequando às exigências e facilidades permitidas. A utilização dos artefatos tecnológicos disponibilizados para a comunidade científica propicia a transformação, contudo, esses não caracterizam a prevalência de um modelo que não é utilizado por parcela significativa da comunidade científica, os pesquisadores dos INCTs da área de Nanotecnologia investigados. O fazer científico desses pesquisadores está em processo de mudança, mas ainda predominam as práticas científicas tradicionais.

A solidificação das redes colaborativas existentes ampliaram o alcance dos resultados de pesquisa e sua disseminação na sociedade em âmbito nacional e internacional. Essas redes favoreceram a produção de informação científica com excelência, bem como a distribuição colaborativa dos recursos e manutenção dos projetos, e permitiram aos pesquisadores da área estudada construirem uma história diferenciada com o avanço da CT\&I nacional. Além de construir possibilidades concretas para a diminuição da dependência científica e tecnológica dos países de ponta, ainda persistente no Brasil.

A atuação das agências de fomento foi classificada entre regular e insatisfatória, de acordo com a indicação dos sujeitos investigados, um percentual correspondente a 54\%, a evidênciar a necessidade de mudanças nesta direção. O trabalho a ser feito é muito grande e é premente o fornecimento efetivo de um arcabouço financeiro e tecnológico que satisfaça às reais necessidades dos pesquisadores e instituições contempladas.

Todos os atores envolvidos na rede de práticas colaborativas para inovação, identificados no conglomerado analisado possuem, cada um a seu turno, uma parcela de responsabilidade sobre as consequências que suas parcerias e ações acarretaram para a sociedade como um todo. Em especial, os agentes de fomento porque sua responsabilidade vai muito além do suporte financeiro. A manutenção de atitudes que primem pela pontualidade e constância, no cumprimento dos acordos firmados, será bem-vinda e constituirá certeza de metas cumpridas. Essa garantia favorecerá cada vez mais o êxito das políticas públicas voltadas para a CT\&I.

Essa atitude possibilitará a continuidade das políticas públicas implementadas e certeza na obtenção de um percentual superior aos 30\% resultantes de uma boa atuação, além da possibilidade de alcance de margens mais significativas de 
aprovação, com benefícios para todos os envolvidos na parceria. A atuação dos agentes de fomento interfere significativamente na manutenção das políticas públicas.

No Brasil, atitudes desse porte, voltadas para o fomento à CT\&I são muito importantes para o desenvolvimento das pesquisas; para a o fornecimento de recursos e manutenção de suporte e infraestrutura; para a formação de recursos humanos; e para o incentivo à transferência de conhecimento e tecnologia. Apesar do cenário nacional estar repleto de controvérsias resultantes das diversas forças políticas em conflito, a esperança por um futuro melhor estará sempre entre nós. Concluiu-se que na realidade brasileira ainda se faz necessário a integração sistemática entre as concepções teóricas e as políticas públicas para a área de Ciência Tecnologia e Inovação. Essa integração pode favorecer a colaboração, a inserção da produção brasileira no cenário internacional e o desenvolvimento científico do país em perspectiva autóctone.

A contribuição que uma pesquisa dessa dimensão ofereceu para a comunidade científica, especialmente para a área em análise, foi fornecer um panorama das práticas colaborativas e infraestrutura de pesquisa pertinentes a uma parcela significativa da área de Nanotecnologia. Embasados nos resultados e conclusões do estudo, podem-se tomar decisões e direcionamentos que conduzam à resolução de dificuldades sinalizadas, bem como se imprimir maior empenho em frentes de atuação sinalizadas e potencias para o sucesso das pesquisas realizadas. Identificaram-se as práticas colaborativas para inovação que a área realiza efetivamente, sua percepção em relação ao modelo INCT e ao modelo $e$-Science e, em especial, foi assinalada a apreensão pela inconstância de uma política pública que conseguiu resultados explêndidos mas que carece de uma gestão mais eficiente dos recursos financeiros envolvidos.

Para a área da Ciência da Informação, a grande contribuição do estudo realizado foi a inserção de uma temática relevante para a área como a $e$-Science e a utilização de uma metodologia que agregou instrumentos diversos e pertinentes aos estudos do domínio. Esses instrumentos foram utilizados de modo combinado e aplicados com adequação, como a Teoria Ator-Rede, o Método Survey, a Análise de Redes Sociais, a Bibliometria e a Análise de Conteúdo, métodos 
mistos utilizados de modo concomitante, os quais poderão ser usados em estudos futuros.

Ao se finalizar um trabalho, fica sempre a sensação de que faltou algo, entretanto, esse algo pode ser perfeitamente a mola propulsora pra novs pesquisas. Sugerem-se alguns pontos que podem ser contemplados como uma continuidade do estudo realizado:

- análise do Programa INCT como um todo, contemplando-se as outras áreas estratégicas para a CT\&I, ausentes neste estudo;

- estudo retrospectivo da produção científica dos pesquisadores dos INCTs de Nanotecnologia com vistas a identificar a interferência na produção da atual formação;

- estudo da produção técnica dos pesquisadores dos INCTs de Nanotecnologia e

- contraponto com a produção científica;

- inclusão dos demais INCTs da área de Nanotecnologia que não foram contemplados na pesquisa;

- análise da dinâmica das redes identificadas de cadeia de inovação, práticas colaborativas para inovação e colaboração científica.

- investigação da utilização de modelos de infraestrutura e-Science em outras áreas do conhecimento;

- aprofundamento de estudos sobre a e-Science voltados para aplicações específicas da Ciência da Informação como, por exemplo, gestão da informação e dados de pesquisa.

Abriu-se um leque de possibilidades e cabe aos pesquisadores se debruçarem sobre essas e empreenderem novos estudos para ampliá-las. Alimentar as incertezas, é sem dúvida, recurso qualificado para superar as dificuldades do percurso. 


\section{REFERÊNCIAS}

ABBAGNANO, Nicola. Dicionário de filosofia. 5. ed. rev. e ampl. São Paulo: Martins Fontes, 2007.

ALBAGLI, Sarita; APPEL, André Luiz; MACIEL, Maria Lucia. E-Science e ciência aberta: questões em debate. In: ENCONTRO NACIONAL DE PESQUISA EM CIÊNCIA DA INFORMAÇÃO, 14., 2013, Florianópolis. Anais... Florianópolis: UFSC, 2013. Disponível em: <http://ridi.ibict.br/handle/123456789/465>. Acesso em: 24 abr. 2014.

ALMEIDA, Marco Antônio de. Práticas, inscrições e redes sociais: contribuições da teoria social para a reflexão sobre a identidade da ciência da Informação. In: FUJITA, Mariângela Spotti Lopes et al. (Org.). A dimensão epistemológica da ciência da informação e suas interfaces técnicas, politicas e institucionais nos processos de produção, acesso e disseminação da informação. São Paulo: Cultura Acadêmica; Marília: Fundep, 2008. p. 37-50.

ANDERY, Maria Amália et al. Para compreender a ciência: uma perspectiva histórica. 12. ed. São Paulo: EDUC; Rio de Janeiro: Garamond, 2003.

ANDRONICO, Giuseppe et al. e-Infrastructures for e-Science: a global view. Journal of Grid Computing, [S.1], v. 2, n. 9, p. 155-184, mar. 2011. Disponível em: $<$ http://link.springer.com/article/10.1007\%2Fs10723-011-9187-y>. Acesso em: 22 fev. 2015. 
ANTONIO, Irati; PACKER, Abel. Seminário sobre avaliação da produção científica: relatório final. Ciência da Informação, Brasília, v. 27, n. 2, p. 219 220, maio/ago. 1998. Disponível em: <www.ibict.br/cienciadainformacao/ viewarticle.php?id=412\&layout=abstract>. Acesso em: 2 nov. 2005.

APAZA YANARICO, Augustín. Uma tecnociência para o bem-estar social. Ciência e Tecnologia Social - A construção crítica da tecnologia pelos autores sociais, Planaltina, DF, v. 1, n. 1, p. 99-120, jul. 2011. Disponível em: <http:// www.periodicos.unb.br/index.php/cts/article/view/5149/4334>. Acesso em: 10 fev. 2016.

ARAÚJO, Ronaldo de; CARDOSO, Ana Maria Pereira. A ciência da informação como rede de atores: reflexões a partir de Bruno Latour. In: ENCONTRO NACIONAL DE PESQUISA EM CIÊNCIA DA INFORMAÇÃO, 8., 2007, Salvador. Anais... Salvador: UFBA, 2007. Disponível em: <https://www.academia. edu/1815936/A_Ci\%C3\%AAncia_da_Informa\%C3\%A7\%C3\%A3o_como_ Rede_de_Atores_reflex\%C3\%B5es_a_partir_de_Bruno_Latour>. Acesso em: 15 jan. 2016.

ARAÚJO, Ronaldo de; FROTA, Maria Guiomar da Cunha; CARDOSO, Ana Maria Pereira. Práticas, inscrições e redes sociotécnicas: contribuições de Bruno Latour e dos estudos sociais da ciência e da tecnologia para a ciência da informação. In: BORGES, Manoel Maria; CASADO, Elias Sanz. (Coord.). A ciência da informação criadora de conhecimento. Coimbra: Universidade de Coimbra, 2009. p. 135-145, v. 2 (Documentos). Disponível em: <http://www.eventos-iuc. com/ocs/public/conferences/1/schedConfs/1/actas_EDIBCIC2009_2.pdf $>$. Acesso em: 5 nov. 2015.

BALANCIERI, Renato. A análise de redes de colaboração científica sob as novas tecnologias de informação e comunicação: um estudo na Plataforma Lattes. Ciência da Informação, Brasília, v. 34, n. 1, p. 64-77, jan./abr. 2005. Disponível em: $<$ http://revista.ibict.br/ciinf/index.php/ciinf/article/view/619/552>. Acesso em: 3 set. 2013.

BALBACHEVSKY, Elizabeth. Processos decisórios em política científica, tecnológica e de inovação no Brasil: análise crítica. In: CENTRO DE GESTÃO E 
ESTUDOS ESTRATÉGICOS. Nova geração de política em ciência, tecnologia e inovação: seminário internacional. Brasília: CGEE, 2010. p. 61-90. Disponível em: $<$ http:// www.cgee.org.br/atividades/redirect.php?idProduto=6390>. Acesso em: 24 jan. 2014.

BARBIERI, José Carlos. Produção e transferência de tecnologia. São Paulo: Ática, 1990. (Fundamentos, 55).

BELL, Gordon. Prefácio. In: TOLLE, Kristin et al. (Org.). O quarto paradigma: descobertas científicas na era da eScience. São Paulo: Oficina de Textos, 2011. p. 11-15.

BELLUZZO, Regina Célia Baptista. Prefácio. In: BASSETTO, Clemilton Luís. Redes de conhecimento: espaço de competência em informação nas organizações contemporâneas. Bauru, SP: Ide@, 2013.p. 7.

BIBLIOTECA DIGITAL BRASILEIRA DE TESES E DISSERTAÇÕES. BDTD. 2014. Disponível em: <http://bdtd.ibict.br/a-bdtd>. Acesso em: 20 abr. 2014. BIBLIOTECA Geoespacial. 2013. Disponível em: <http://geo.cnpma.embrapa. br/>. Acesso em: 22 jun. 2013.

BLOOR, David. Anti-Latour. Studies in history and philosophy of science. New York, v. 30, n. 1, p. 81-112. 1999. Disponível em : <http://ac.els-cdn.com.ez10. periodicos.capes.gov.br/S0039368198000387/1-s2.0-S0039368198000387main.pdf?_tid=ec3ed278-c429-11e5-962f-00000aab0f26\&acdnat $=1453812186$ 1f5c597a31ae4b9b225b26a64de37262>. Acesso em: 26 jan. 2016.

BLOOR, David. Knowledge and social imagery. Londres: Routledge Direct, 1976. Disponível em: <http://14.139.206.50:8080/jspui/bitstream/1/1336/1/Bloor,\%20 David\%20-\%20Knowledge\%20and\%20social\%20imagery\%201976.pdf>. Acesso em: 25 jan. 2016.

BORGES, Mario Neto. As fundações estaduais de amparo à pesquisa e o desenvolvimento da ciência, tecnologia e inovação no Brasil. Revista USP, São Paulo, n. 89, p. 174-189, mar./maio, 2011. Disponível em: <http://www.revistas. usp.br/revusp/article/view/13876/15694>. Acesso em: 2 abr. 2014. 
BRANDÃO, Wladmir Cardoso; PARREIRAS, Fernando Silva; SILVA, Antonio Braz de Oliveira. Redes em ciência da informação: evidências comportamentais dos pesquisadores e tendências evolutivas das redes de co-autoria. Informação e Informação, Londrina, v. 12, n. esp., 2007. Disponível em: <http:/|www.uel.br| revistas/uel/index.php/informacao/article/view/1778/1516>. Acesso em: $8 \mathrm{dez}$. 2013.

BRASIL. Medida Provisória n ${ }^{\circ} 541$, de 2 de agosto de 2011. Dispõe sobre o Fundo de Financiamento à Exportação, altera as Leis n ${ }^{\circ} \mathrm{s} 12.096$, de 24 de novembro de 2009, 11.529, de 22 de outubro de 2007, 10.683, de 28 de maio de 2003, 5.966, de 11 de dezembro de 1973, e 9.933, de 20 de dezembro de 1999, e dá outras providências. Diário Oficial da União, Brasília, 3 out. 2011. p. 9. Exposição de motivos. Disponível em: <http://www.planalto.gov.br/ CCIVIL_03/_Ato2011-2014/20"/Exm/EMI-123-MF-MDIC-MP-MCT-Mpv541. htm>. Acesso: 10 maio 2016.

BRASIL. Ministério da Ciência e Tecnologia. Secretaria de Desenvolvimento Tecnológicoe Inovação. Coordenação-Geral de Micro e Nanotecnologia. Nanotecnologia: investimentos, resultados e demandas, Brasília, 2006. Disponível em: <http//www.mct.gov.br/upd_blob/0019/19536.pdf>. Acesso em: 10 maio 2016.

BRASIL. Ministério de Ciência e Tecnologia. Plano de Ação em Ciência, Tecnologia e Inovação: principais resultados e avanços 2007-2010. Brasília, 2010. 168 p. Disponível em: <http://www.inovacao.unicamp.br/report/intePACATI_110207.pdf> . Acesso em: 19 abr. 2014.

BRASIL. Portaria n 429, de 17 de julho de 2008. Diário Oficial da União, Brasília, 6 out. 2008. Seção 1, p. 9. Disponível em: <http://pesquisa.in.gov.br/imprensa/jsp/ visualiza/index.jsp?data $=06 / 10 / 2008 \&$ jornal $=1 \&$ pagina $=9 \&$ total Arquivos $=80>$. Acesso em: 28 mar. 2016.

BRNA, Paul. Modelos de colaboração. Revista Brasileira de Informática na Educação, Florianópolis, v. 3, n. 1, p. 9-15, set. 1998. Disponível em: <http://www.br-ie.org/ pub/index.php/rbie/article/view/2298/2060>. Acesso em: 17 set. 2013. 
BUFREM, Leilah Santiago. Colaboração científica: revisando vertentes na literatura em Ciência da Informação no Brasil. Tendências da Pesquisa Brasileira em Ciência da Informação, Brasília, v. 3, v. 1, p. 127-151, jan. /dez. 2010. Disponível em: <http://inseer.ibict.br/ancib/index.php/tpbci/article/view/32/63>. Acesso em: 9 set. 2013.

CARRARA, Sérgio. Uma "tempestade" chamada Latour: a antropologia da ciência em perspectiva. Physis: Revista Saúde Coletiva, Rio de Janeiro, v. 12, n. 1 , p. 180-188, jan./jun. 2002. Disponível em: <www.scielo.br/physis/v12n1/a12. pdf>. Acesso em: 17 ago. 2015.

CASTELLS, Manuel. A sociedade em rede. 9. ed. rev. e ampl. São Paulo: Paz e Terra, 2006. (A Era da informação: economia, sociedade e cultura, 1).

CASTRO, Fábio. INCTs têm primeira avaliação. Agência FAPESP, São Paulo, 25 nov. 2010. Disponível em: <http://agencia.fapesp.br/incts_tem_primeira_ avaliacao/13089/>. Acesso em: 26 dez. 2013.

CASTRO, Maira Murrieta; CUNHA, Murilo Bastos da. A literatura internacional sobre e-Science nas bases de dados LISA e LISTA. Encontros Bibli: Revista Eletrônica de Biblioteconomia e Ciência da Informação, Florianópolis , v. 20, n. 44, p. 127-144, set./dez. 2015. Disponível em: <https://periodicos.ufsc.br/index. php/eb/article/download/1518-2924.2015v20n44p127/30493> . Acesso em: 16. mar. 2016.

\section{CENTRO DE GESTÃO E ESTUDOS ESTRATÉGICOS (Brasil). Avaliação de} políticas de ciência, tecnologia e inovação: diálogo entre experiências internacionais e brasileiras. Brasília, 2008. Disponível em: <http://www.cgee.org.br/publicacoes/ seminario_internacional.php>. Acesso em: 20. jan. 2014.

CENTRO DE GESTÃo E ESTUDOS ESTRATÉGICOS (Brasil). Construção de modelo para avaliar Programa INCTs está na fase final. Jornal da Ciência, São Paulo, n. 4167, 29 dez. 2010. Disponível em: <http://www.jornaldaciencia. org.br/edicoes/?url=http://jcnoticias.jornaldaciencia.org.br/4-construcao-demodelo-para-avaliar-programa-incts-esta-na-fase-final/>. Acesso em: 8 abr. 2014. 
CESAR JUNIOR, Roberto Marcondes. Apresentação à edição brasileira. In: HEY, Tony; TANSLEY, Stewart; TOLLE, Kristin. (Org.). O quarto paradigma: descobertas científicas na era da eScience. São Paulo: Oficina de Textos, 2011. p. 7-8.

CHAVES, Alaor. Nanociência e Nanotecnologia. ComCiência - Revista Eletrônica em Jornalismo Cientifico, São Paulo, v. 37, nov. 2002. Disponível em: <http:// www.comciencia.br/reportagens/framereport.htm>. 14 maio 2016.

CHESBROUGH, Henry. Modelos de negócios abertos: como prosperar no novo cenário da inovação. Porto Alegre: Bookman, 2012.

CLARKE, Richard; Hunker, JEFFREY. Press Briefing: the White House Office of the press secretary. 1998. Disponível em: <http://www.fas.org/irp/ news/1998/05/980522-wh3.htm>. Acesso em: 9 jun. 2013.

CNPq. Periódicos: histórico, Brasília, 2011. Disponível em : $<$ http://www.periodicos.capes.gov.br/index.php?option=com pcontent\&view $=$ pcontent\&alias $=$ historico $\& m n=69 \& s m n=87>$. Acesso em: 1 jun. 2011.

CNPq. Tabela de áreas de conhecimento/avaliação. Brasília, 2012. Disponível em: $<$ http://www.capes.gov.br/avaliacao/instrumentos-de-apoio/tabela-de-areasdo-conhecimento-avaliacao>. Acesso em: 9 maio 2016.

CNPq. Coordenação de Comunicação Social. Seminário de Acompanhamento e Avaliação dos INCT acontece em Brasília. SEMINÁRIO NACIONAL DE ACOMPANHAMENTO E AVALIAÇÃO DOS INCT, 2. 2003, Brasília. Anais... 2013a. Disponível em: <http://cnpq.br/noticiasviews/-/journal_content/56_ INSTANCE_a6MO/10157/1106851>. Acesso em: 17 maio 2016.

CNPq . Coordenação de Comunicação Social. CNPq divulga resultado do julgamento da chamada INCT-MCT/CNPQ/CAPES/FAPS N 16/2014. Brasília, 2016a.

Disponível em: $<$ http://cnpq.br/web/guest/noticiasviews/-/journal_content/56_ INSTANCE_a6MO/10157/4855210>. Acesso em: 17 maio 2016.

CNPq. Chamada INCT - MCTI/CNPq/CAPES/FAPs n ${ }^{\circ}$ 16/2014. Brasília, 2014a. Disponível em: <http://www.cnpq.br/documents/10157/b91b7566-2110-4a299704-88cdd324e072>. Acesso em: 17 maio 2016. 
CNPq. Edital MCT/CNPq/FNDCT N ${ }^{\circ}$ 71/2010 - Institutos Nacionais de Ciência e Tecnologia em Ciências do Mar. Brasília, 2010. Disponível em: <http://resultado. cnpq.br/5849265638165964>. Acesso em: 19 mar. 2016.

CNPq. Edital Nº 15/2008 - MCT/CNPQ/FNDCR/CAPES/FAPEMIG/ FAPEMIG/ FAPERJ/FAPESP/INSTITUTOS NACIONAIS DE CIÊNCIA E TECNOLOGIA. Brasília, 2008. Disponível em: <http://www.fapesp.br/chamadas/inct2008.pdf>. Acesso em: 19 mar. 2016.

CNPq. Institutos Nacionais de Ciência e Tecnologia. Instituto Nacional de Ciência e Tecnologia de Nanodispositivos Semicondutores - DISSE. Brasília, 2008b. Disponível em: <http://estatico.cnpq.br/programas/inct/_apresentacao/inct_ nanodispositivos_semicondutores.html>. Acesso em: 17 abr. 2016.

CNPq. INCT-DISSE desenvolve chip de silício para leitura de fotodetectores. Brasília: MCTI, 2013b. Disponível em: <http://cnpq.br/web/guest/noticiasviews/-/ journal_content/56_INSTANCE_a6MO/10157/1054232>. Acesso em: 16 abr. 2016.

CNPq. INCT: Institutos Nacionais de Ciência e Tecnologia. Brasília, 2013c. Disponível em: <http://estatico.cnpq.br/programas/inct/_apresentacao/docs/ livro2013.pdf>. Acesso em: 29 nov. 2013.

CNPq. Instituto Nacional de Ciência e Tecnologia de Nanobiotecnologia do Centro-Oeste e Norte. Relatório de acompanhamento de projeto: período - (início do INCT até abril/2013). Brasília, DCOI, 2013 d.

CNPq. Instituto Nacional de Ciência e Tecnologia de Nanomateriais de Carbono. Relatório de acompanhamento de projeto: período - (início do INCT até abril/2013). Brasília, 2013e.

CNPq. Instituto Nacional de Ciência e Tecnologia de Nanodispositivos Semicondutores. Relatório de acompanhamento de projeto: período - (início do INCT até abril/2013). Brasília, $2013 f$.

CNPq. Instituto Nacional de Ciência e Tecnologia de Sistemas Micro e Nanoeletrônicos. Relatório de acompanhamento de projeto: período - (início do INCT até nov./2014). Brasília, DCOI, 2014b. 
CNPq. Nanotecnologia: Instituto Nacional de Ciência e Tecnologia de Nanobiotecnologia - INCT Nanobiotecnologia. Brasília: MCTI, $2016 \mathrm{~b}$. Disponível em: <http://inct.cnpq.br/web/inct-nanobiotecnologia>. Acesso em: 22 mar. 2016.

CNPq. Nanotecnologia: Instituto Nacional de Ciência e Tecnologia em Sistemas Moleculares e Nanoestruturados - INCT-Catálise. Brasília: MCTI, 2016c.

Disponível em: <http://inct.cnpq.br/web/inct-catalise>. Acesso em: 5 abr. 2016.

COSTA, Sely M. S. Filosofia aberta, modelos de negócios e agências de fomento: elementos essenciais a uma discussão sobre o acesso aberto à informação científica. Ciência da Informação, Brasília, v. 35, n. 2, p. 39-50, maio/ago. 2006. Disponível em: <http://repositorio.unb.br/bitstream/10482/634/1/ARTIGO_ FilosofiaAbertaModelosNeg\%C3\%B3cios.pdf>. Acesso em: 28 abr. 2014.

CROW, Raym. The case for institutional repositories: a SPARC position paper. Washington: SPARC, 2002. Disponível em: <http://www.arl.org/sparc/bm doc/ ir_final_release_102.pdf> Acesso em: 5 fev. 08.

CUNHA, Antônio Geraldo da. Dicionário etimológico da língua portuguesa. 4. ed. rev. e atual. Rio de Janeiro: Lexikon, 2011.

CUNHA, Murilo Bastos da; CAVALCANTI, Cordélia Robalinho de Oliveira. Dicionário de biblioteconomia e arquivologia. Brasília: Briquet de Lemos, 2008. DEAN, Jeffrey; GHEMAWAT, Sanjay. Reduce: simplified data processing on large clusters. To appear in OSDI, 2004. Disponível em: $<$ http://static. googleusercontent.com/media/research.google.com/pt-BR//archive/ mapreduce-osdi04.pdf>. Acesso em: 11 ago. 2016.

DIAS, Leila Christina; SILVEIRA, Rogério Leandro Lima da. (Org.) Redes, sociedades e territórios. Santa Cruz do Sul: EDUNISC, 2005.

DUARTE, Fábio; QUANDT, Carlos; SOUZA, Queila. (Org.). O tempo das redes. São Paulo: Perspectiva, 2008. (Big Bang).

E-SCIENCE. [2012]a. Disponível em: <http://hlwiki.slais.ubc.ca/index.php/EScience>. Acesso em: 11 jul. 2012. 
E-SCIENCE Grid. [2012]b. Disponível em: < http://www.escience-grid.org.uk/ what-e-science.html>. Acesso em: 5 jul. 2012.

ESCALANTE LUDEÑA, Mercy. Avaliação de redes de inovação em nanotecnologia: a proposta de um modelo. 2008. 177 f. Tese (Doutorado em Administração) - Faculdade de Economia, Administração e Contabilidade, Universidade de São Paulo, São Paulo, 2008. Disponível em: <www.teses.usp.br/teses| disponiveis/12/12139/tde-11122008.../Tese_Mercy.pdf>. Acesso em: 2 jul. 2016.

FERREIRA, Hadma Sousa; RANGEL, Maria do Carmo. Nanotecnologia: aspectos gerais e potencial de aplicação em catálise. Química Nova, São Paulo, v. 32, n. 7, p. 1860-1870, 2009. Disponível em: <http://quimicanova.sbq.org.br/ imagebank/pdf/Vol32No7_1860_32-RV08203.pdf>. Acesso em: 10 maio 2016.

FERREIRA, Valdinéia Barreto. Acesso e uso dos repositórios digitais: comportamento informacional dos pesquisadores da Ciência da Informação no Brasil. 2009. 202 f. Dissertação (Mestrado em Ciência da Informação) - Instituto de Ciência da Informação, Universidade Federal da Bahia. Salvador, 2009.

FERREIRA, Valdinéia Barreto. e-Science e políticas públicas para ciência, tecnologia e Inovação no Brasil: colaboração, infraestrutura e repercussão nos Institutos Nacionais de Ciência e Tecnologia da Área de Nanotecnologia. 2016. 400 f. Tese (Doutorado em Ciência da Informação) - Instituto de Ciência da Informação, Universidade Federal da Bahia, Salvador, 2016.

FERREIRA E BAPTISTA, Rosanita. Constituição e reconfiguração da sociologia da ciência: as abordagens de Merton, Bloor e Latour. In: CONGRESSO BRASILEIRO DE SOCIOLOGIA, 14., 2009, Rio de Janeiro. Anais.... Rio de Janeiro: Sociedade Brasileira de Sociologia, 2009. Disponível em: $<$ http://www. sbsociologia.com.br/portal/index.php?option=com_docman\&task $=$ doc donwload\&gid=3685\&Itemid=171>. Acesso em: 25 março 2014.

FINHOLT, Thomas A.; OLSON, Gary M. From laboratories to collaboratories: a new organizational from for scientific collaboration. Psychological Science, Washington, v. 8, n. 1, p. 28-36, jan. 1997. Disponível em: <http://pss.sagepub. com/content/8/1/28.full.pdf+html>. Acesso em: 25 mar. 2014. 
FRANÇA, Andre Luiz Dias de; PINHO NETO, Julio Afonso Sá de DIAS, Guilherme Ataíde. A Ciência da Informação e o pensamento de Bruno Latour: implicações para a análise de redes sociais. Informação e Sociedade: Estudos, João Pessoa, v. 25, n. 1, p. 137-144, jan./abr. 2015. Disponível em: <http://www.ies. ufpb.br/ojs/index.php/ies/article/view/13>. Acesso em: 18 jul. 2015.

FRANCO, A. Cocriação: reinventando o conceito. 2. ed. rev. e ampl. São Paulo, 2012. (Escola de Redes, 17). Disponível em: <http://pt.slideshare. net/augustodefranco/cocriao-reinventando-o-conceito-14554143?from_ action=save $>$. Acesso em: 29 jul. 2014.

FUNDAÇÃO DE AMPARO À PESQUISA DO ESTADO DE SÃO PAULO. Call for Research Proposals - eScience. São Paulo, 2014. Disponível em: <http://www.fapesp. br/en/8354>. Acesso em: 9 maio 2016.

FUNDAÇÃO DE AMPARO À PESQUISA DO ESTADO DE SÃO PAULO. Latin American eScience Workshop. São Paulo, 2013. Disponível em: <http://www.fapesp. br/7458>. Acesso em: 22 jun. 2013.

FUNDAÇÃO DE AMPARO À PESQUISA DO ESTADO DE SÃO PAULO. Programa FAPESP de Pesquisa em eScience. eScience. São Paulo, 2015. Disponível em: <www.fapesp.br/publicações/2015/folder_escience.pdf>. Acesso em: 9 maio 2016.

GOLD, Anna. Cyberinfrastructure, data, and libraries, part 1: a cyberinfrastructure primer for librarians, D-Lib Magazine, Virginia, v. 3, n. 9/10, set./out. 2007. Disponível em: <http://digitalcommons.calpoly.edu/cgi/ viewcontent.cgi?article=1015\&context=lib_dean>. Acesso em: 26 mar. 2013. GONZÁLEZ ALCAÍDE, Gregório et. al. La colaborácion científica como objeto de estudio. In: GONZÁLEZ ALCAÍDE, Gregório et al. La colaborácion científica: una aproximación multidisciplinary. Valencia: Nau Libres, 2013. p. 13-16.

GRAY, Jim; SZALAY, Alex. eScience: a transformed scientific method. Mountain View, Califórnia, 11 jan. 2007. Palestra apresentada no Conselho Nacional de Pesquisa dos Estados Unidos (NRC-CSTB). Disponível em: http://research. 
microsoft.com/en-us/um/people/gray/talks/nrc-cstb_escience.ppt $>$. Acesso em: 7 jul. 2016.

GUERREIRO, Luis. Lectinas: você sabe o que é isso? Alimentação Viva e Sustentável. 2008. Disponível em: <alimentacaoviva.blogspot.com.br/2008/11/lectinas-vocsabe-o-que-isso.html>. Acesso em: 6 abr. 2016.

HEY, Tony; HEY, Jessie. e-Science and its implications for the library community. Library Hi Tech, Bingley, v. 24, n. 4, p. 515-528, 2006. Disponível em: <http://www. emeraldinsight.com/journals.htm?articleid=1583887\&show=abstract $>$. Acesso em: 25 mar. 2014.

HEY, Tony; TREFETHEN, Anne. Cyberinfrastructure for e-Science. Science, Washington, v. 308, n. 5723, p. 817-821, maio. 2005. Disponível em: <http:// www.sciencemag.org/content/308/5723/817.full>. Acesso em: 10 ago. 2013. INCT. Catálogo Coletivo Nacional (CCN). Brasília, 2005. Disponível em <http:/| www.ibict.br/secao.php?cat=ccn>. Acesso em: 1 jun. 2011.

INCT. INCT Catálise. Florianópolis, 2014a. Disponível em: <http://www.inctcatalise.com.br/Instituto/index.html>. Acesso em: 7 abr. 2014.

INCT. INCT NANOBIOFAR. Minas Gerais, 2014b. Disponível em: <http://www. inctnanobiofar.com.br/\#!about_us/cjg9>. Acesso em: 7 abr. 2014.

INCT. Instituto Nacional de Ciência e Tecnologia em Nanomateriais de Carbono. Minas Gerais, 2014c. Disponível em: <http://www.nanocarbono.net/pagina. php?pag=about >. Acesso em: 8 abr. 2014.

INCT. INCT Namitec. Campinas, SP, 2014d. Disponível em: <http://www. namitec.org.br/>. Acesso em: 8 abr. 2014.

INCT. INOMAT. Campinas, 2014e. Disponível em: <http://www.inomat.iqm. unicamp.br/oinstituto/oinstituto.php>. Acesso em: 5 abr. 2014.

INCT. Lançamento da chamada pública INCT-2014. Brasília, 2016. Disponível em: $<$ http://inct.cnpq.br/documents/10180/124986/Apresentacao_Chamada_ INCT_2014.pdf/0a4623b3-8191-4c1a-87b4-d8335072fda2>. Acesso em: 17 maio 2016. 
INCT. NANOBIOSIMES. Fortaleza, 2014f. Disponível em: $<$ http://www. nanobiosimes.ufc.br/index.php/apresentacao> Acesso em: 7 abr.2014.

INCT. Novo programa de financiamento de pesquisa privilegia cooperação entre pesquisadores: Petrobras e BNDES estão entre financiadores. Inovação Unicamp, Campinas, dez. 2008. Disponível em: <http://www.inovacao.unicamp. br/destaques/novo-programa-de-financiamento-de-pesquisa-privilegiacooperacaoentre-pesquisadores-petrobras-e-bndes-estao-entre-financiadores> Acesso em: 8 abr. 2008.

IZIQUE, Claudia. FAPESP lança programa para projetos em eScience. Agência FAPESP, São Paulo, 2013. Disponível em: <http://agencia.fapesp.br/18346>. Acesso em: 25. mar. 2014.

JANKOWSKI, Nicholas W. e-Research: transformation in scholary practice. In: JANKOWSKI, Nicholas W. E-research: transformation in scholarly practice an enhanced publication accompanying the traditionally published book. [S.1]: Routledge, 2009. Disponível em: <scholarly transformations. Virtualknowledgestudio.nl>. Acesso em: 10 jul. 2012.

JANKOWSKI, Nicholas W. Exploring e-Science: an introduction. Journal of Computer-Mediated Communication, Philadelphia, US, v. 12, n. 2, p. 549-562, fev. 2007. Disponível em: <http://onlinelibrary.wiley.com/doi/10.1111/j.10836101.2007.00337.x/pdf>. Acesso em: 29 jun. 2013.

KUHN, Thomas S. A estrutura das revoluções cientificas. Tradução de Beatriz Vianna e Nelson Boeira. 10. ed. São Paulo: Perspectiva, 2011. (Debates, 115)

LANZEL, Wolfgang; SCHUBERT, András. Analyzing scientific networks through co-authorship. In: MOED, Henk F. et al. (Ed.). Handbook of Quantitative Science and Technology Research. Holanda: Kluwer Academic Publishers, 2004. Cap. 11.p. 257-276. Disponível em: <http://citeseerx.ist.psu.edu/viewdoc/ download?rep=rep1\&type=pdf\&doi=10.1.1.86.4083> Acesso em: 9 set. 2013. LARA, Marilda Lopes Ginez de; LIMA, Vânia Mara Alves. Termos e conceitos sobre redes sociais colaborativas. In: POBLACIÓN, Dinah Aguiar; MUGNAINI, 
Rogério; RAMOS, Lúcia Maria S. V. Costa (Org.). Redes sociais e colaborativas em informação científica. São Paulo: Angellara, 2009. p. 605-637.

LATOUR, Bruno. A esperança de Pandora: ensaios sobre a realidade dos estudos científicos. Tradução de Gilson César Cardoso de Sousa. Bauru,SP: EDUSC, 2001. (Filosofia e Política).

LATOUR, Bruno. Reagregando o social: uma introdução à Teoria do Ator-Rede. Tradução de Gilson César Cardoso de Sousa. Salvador: EDUFBA; Bauru: EDUSC, 2012.

LEMOS, André . A comunicação das coisas: teoria ator-rede e cibercultura. São Paulo: Annablume, 2013. (Atopos).

LEMOS, Dannyela da Cunha; CÁRIO, Silvio Antonio Ferraz. A evolução das políticas de ciência e tecnologia no Brasil e a incorporação da inovação. In: CONFERÊNCIA INTERNACIONAL LALICS, 2013., Rio de Janeiro.[Anais...]. Rio de Janeiro: LALICS, 2013. Disponível em: <http://www.redesist.ie.ufrj.br/ lalics/papers/20_A_Evolucao_das_Politicas_de_Ciencia_e_Tecnologia_no_ Brasil_e_a_Incorporacao_da_Inovacao.pdf $>$. Acesso em: 18 jan. 2014. LETA, Jaqueline; CRUZ, Carlos Henrique de Brito. A produção científica brasileira. In: VIOTTI, Eduardo Baumgratz; MACEDO, Mariano de Matos. (Org). Indicadores de ciência, tecnologia e inovação no Brasil. Campinas: Ed. Unicamp, 2003. p. 121-168.

LÉVY, Pierre. Cibercultura. Tradução de Carlos Irineu da Costa. São Paulo: Ed. 34, 1999.

LIBERATO, Tatiane Furukawa; RUFO, Carla Renata; STANGE, Simone Moraes. A Tecnociência sob o olhar de Bruno Latour. In: SIMPÓSIO DE DESENVOLVIMENTO TECNOLOGIAS E SOCIEDADE, 4., 2014, Itajubá. Anais... Itajubá: UNIFEI, 2014. Disponível em: <http://www.sidtecs.com.br/2014/wpcontent/uploads/2014/10/823.pdf>. Acesso em: 18 jul. 2015

LIMA, Manoel Eusébio de. Eletrônica: dispositivos optoeletrônicos - introdução. Pernambuco: Grupo de Engenharia da Computação/UFPE, 2006. Disponível 
em: <http://www.cin.ufpe.br/ ags/eletr\%F4nica/aula11_optoeletronica.pdf >. Acesso em: 17 abr. 2016.

MALTA, Oscar Manoel Loureiro et al. Nanotecnologia de marcadores (INAMI): parte 1 de 2. Bíblia Comentada. [2009]. Disponível em: <http://bibliacomentada. com/ArtigosDetalhes.aspx?IdArtigo =16331\&Titulo=Nanotecnologia\%20de $\% 20$ marcadores\%20(INAMI)\%20-\%20Parte\%201\%20de\%202\#axzz453ZwTs8w> Acesso em: 6 abr. 2016.

MARICATO, João de Melo. Dinâmica das relações entre Ciência e Tecnologia: estudo Bibliométrico e Cientométrico de múltiplos indicadores de artigos e patentes em biodiesel. 2010. 378 f. Tese (Doutorado em Ciência da Informação) - Escola de Comunicação e Artes, Universidade de São Paulo, São Paulo, 2010.

MARQUEZ, Allan Cancian et al. Gephi: um software open source de manipulação e visualização de grafos. Oficina Gephi: mapeando e analisando a vida das redes sociais. [Vitória]: UFES-LABIC, 2013. Disponível em: < https://docs.google.com/document/d/1EwpPl3jdgVd_ qu0E0fj4HsYHUbT6Lgfjs7gtNYg_iDo/edit>. Acesso em: 20 fev. 2015.

MARQUES, Eduardo Cesar. Estado e redes sociais: permeabilidade e coesão nas políticas urbanas no. Rio de Janeiro: Revan; São Paulo: FAPESP, 2000. Disponível em: <https://www.researchgate.net/publication/281524071_Estado_e_redes_ sociais_permeabilidade_e_coesao_nas_politicas_urbanas_no_Rio_de_Janeiro_ Rio_de_Janeiro_Ed_RevanFapesp_2000>. Acesso em: 20 fev. 2016.

MARTELETO, Regina Maria. Análise de sociais: aplicação nos estudos de transferência da informação. Ciência da Informação, Brasília, v. 30, n. 1, p. 7181, jan./abr. 2001. Disponível em: <http://revista.ibict.br/ciinf/index.php/ciif/ article/view/226/2001>. Acesso em: 8 dez. 2013.

MARTELETO, Regina Maria; TOMAÉL, Maria Inês. A metodologia de análise de redes sociais. In: VALENTIM, Marta Ligia Pomim (Org.). Métodos qualitativos de pesquisa em ciência da informação. São Paulo: Polis, 2005. (Palavra - Chave, 16). 
MARTINS, Pablo Procópio. Glossário. Santa Catarina, CELESC, 2011. p. 7. Disponível em: <http://portal.celesc.com.br/portal/ped/index.php/glossario>. Acesso em: 10 jul. 2016.

MARTINS, Pablo (Coord.). Nanotecnologia, sociedade e meio ambiente em São Paulo, Minas Gerais e Distrito Federal. São Paulo: Xamã, 2007. Disponível em: <http:/| pt.slideshare.net/ProjetoBr/nanotecnologia-sociedade-e-meio-ambiente-em-sopaulo-minas-gerais-e-braslia>. Acesso em: 17 maio 2016.

MATHEUS, Renato Fabiano; SILVA, Antonio Braz de Oliveira e. Análise de redes sociais como método para a Ciência da Informação. DataGramaZero - Revista de Ciência da Informação, Rio de Janeiro, v. 7, n. 2, p. 1-21, abr. 2006. Disponível em: <http:// www.Dgz.org.br/abr06/Art_03.htm>. Acesso em: 7 dez. 2013. MATHIAS, Simão. Apresentação da edição brasileira. In: SOLLA PRICE, Derek J. de. O desenvolvimento da ciência: análise histórica, filosófica, sociológica e econômica. Tradução de Simão Mathias com colaboração de Gilda Maria Braga. Rio de Janeiro: Livros Técnicos e Científicos, 1976.

MEADOWS, Arthur Jack. A comunicação científica. Brasília: Briquet de Lemos, 1999.

MEDEIROS, Luciano Frontino de. A construção de um ideal tecnocientífico. Perspectivas em Gestão e Conhecimento, João Pessoa, v. 2, n. 2, p. 43-56, jul./ dez. 2012. Disponível em: <periodicos.ufpb.br/index.php/pgc/article/ viewFile/12768/8473>. Acesso em: 14 fev. 2016.

MENA-CHALCO, Jesús; CESAR JÚNIOR, Roberto Marcondes. ScriptLattes: um sistema de extração de conhecimento open-source da Plataforma Lattes, Journal of the Brazilian Computer Society, Campinas, v. 15, n. 4, p. 31-39, dez. 2009. Disponível em: <http://www.scielo.br/scielo.php?pid=S010465002009000400004\&script=sci_arttext>. Acesso em: 22 jun. 2013.

MENDES, Luis Augusto Lobão. Redes de colaboração: o poder da colaboração em massa. Revista DOM, Minas Gerais, p. 95-105, 2009. Disponível em: <http:/| www.slideshare.net/LuisLobaoMendes/o-poder-da-colaborao-revista-domfdc>. Acesso em: 4 nov. 2013. 
MENEGHINI, Rogério. Avaliação da produção científica e o Projeto SciELO. Ciência da Informação, Brasília, v. 27, n. 2, p. 219-220, maio/ago. 1998. Disponível em: <http://www.scielo.br/pdf/ci/v27n2/meneghini.pdf >. Acesso em: 1 jun. 2011.

MICROSOFT. Dryad. 2016. Disponível em: <https://www.microsoft.com/en-us/ research/project/dryad/>. Acesso em: 12 ago. 2016.

MORAIS, Regis de. Filosofia da ciência e da tecnologia: introdução metodológica e crítica. 5. ed. Campinas: Papiros, 1988.

MOTTA, Débora. Worksshop na PUC-Rio difunde conhecimento em tecnologia de infravermelho. FAPERJ, Rio de Janeiro, 2011. Disponível em: <http://www. faperj.br/?id=2099.2.2>. Acesso em: 18 abr. 2016.

MOURA, Maria Aparecida; MORAES, Bruno. [Colabortório digital da UFMG]: introdução. 2015. Disponível em: <https://www.ufmg.br/proex/cpinfo/ colaboratorio/pt/introducao/>. Acesso em: 21 fev. 2015.

MUNDIE, Craig. O caminho adiante. In: TOLLE, Kristin et al. (Org.). O quarto paradigma: descobertas científicas na era da eScience. São Paulo: Oficina de Textos, 2011. p. 231-233.

MUELLER, Suzana Pinheiro Machado . A publicação da ciência: áreas científicas e seus canais preferenciais. DataGramaZero - Revista de Ciência da Informação, Rio de Janeiro, v. 6, n. 1, fev. 2005. Disponível em: <http://repositorio.unb.br/ bitstream/10482/980/2/ARTIGO_PublicacaoCiencia.pdf>. Acesso em: 9 jul. 2016.

MUELLER, Suzana Pinheiro Machado. Literatura científica, comunicação e ciência da informação. In: TOUTAIN, Lídia Maria Batista Brandão. (Org.). Para entender a ciência da informação. Salvado: EDUFBA, 2007. p. 125-144. Disponível em: <https://repositorio.ufba.br/ri/bitstream/ufba/145/1/Para\%20entender\%20 a\%20ciencia\%20da\%20informacao.pdf>. Acesso em: 18 jun. 2015.

MUSSO, Pierre. A filosofia da rede. In: PARENTE, André (Org.). Tramas da rede: novas dimensões filosóficas, estéticas e políticas da comunicação. Porto Alegre: Sulina, 2013.p. 17-38. (Cibercultura) 
MUSTAFA, Solange Puntel. Um banho de empirismo: de Hume/Deleuze ao empirismo radical de Bruno Latour. Revista de Ciência da Informação e Documentação, Ribeirão Preto, v. 1, n. 1, p. 161-181, 2010. Disponível em: <http:// www.revistas.usp.br/incid/article/view/42311>. Acesso em: 18 jul. 2015. NANOTECNOLOGIA? “A nova era do século XXI.” 2009. Nanotecnologia, São Jõao da Madeira, 17, 10 fev. 2009. Disponível em: <http://nanotecnologianano tecnologia.blogspot.com.br/>. Acesso em: 15 maio 2016.

OCDE. Science, Tchnology and Industry: scoreboard. 2009. Disponível em: <http://www.oecd-ilbrary.org/docserver/download/9209031e. pdf?expires $=1397941570 \& \mathrm{id}=\mathrm{id} \&$ accname $=$ guest $\&$ checksum $=$ 17B631A1B91CEA22FA066D497C7A10F3>. Acesso em: 19 abr. 2014.

OCDE. Manual de Frascati: metodologia proposta para levantamentos sobre pesquisa e desenvolvimento experimental. Tradução de Olivier Isnard. [São Paulo]: F-INICIATIVAS P+D+I, 2013. Disponível em: <http://www.mct.gov.br/ upd_blob/0225/225728.pdf>. Acesso em: 11 jul. 2016.

ODDONE, Nanci E. et al. Centros de cálculo: a mobilização do mundo. Informare: Cadernos do programa de pós-graduação em ciência da informação. Rio de Janeiro, v. 6, n. 1, p. 29-43, jan./jun. 2000.

OLIVEIRA, Bernardo Jefferson de. Francis Bacon e a fundamentação da ciência como tecnologia. 2. ed. Belo Horizonte: UFMA, 2010.

OLIVEIRA, Viviam. O crowdsourcing a frente da mídia colaborativa e democrática: uma perspectiva cidadã para a Web 2.0. In: CONFERÊNCIA SULAMERICANA, 3., CONFERÊNCIA BRASILEIRA DE MÍDIA CIDADÃ, 8., 2012, Brasília. Anais... Brasília: Rede Brasileira de Mídia Cidadã, 2012. Disponível em: <http://www.unicentro.br/redemc/2012/artigos/34.pdf>. Acesso em: 28 abr. 2014.

OTAVIANO, Carolina. A institucionalização da pesquisa e o sistema nacional de CT\&I no Brasil. ComCiência: Revista Eletrônica em Jornalismo Científico, Campinas, n. 129, [p. 1-3]. 2011. Disponível em: <http://comciencia.scielo.br/ pdf/cci/n129/a03n129.pdf>. Acesso em: 8 abr. 2016. 
PARASTATIDIS, Savas. Uma plataforma para tudo que sabemos: criando uma infraestrutura de pesquisa orientada ao conhecimento. In: HEY, Tony; TANSLEY, Stewart; TOLLE, Kristin. (Org.). O quarto paradigma: descobertas científicas na era da eScience. São Paulo: Oficina de Textos, 2011. p. 175-181. PARENTE, André (Org.). Tramas da rede: novas dimensões filosóficas, estéticas e políticas da comunicação. Porto Alegre: Sulina, 2013. (Cibercultura).

PARREIRAS, Fernando Silva et. al. REDECI: colaboração e produção científica em ciência da informação no Brasil. Perspectiva em Ciência da informação, Belo Horizonte, v. 11, n. 6, p. 302-317, set./dez. 2006. Disponível em: <http:/| portaldeperiodicos.eci.ufmg.br/index.php/pci/article/view/270/63>. Acesso em: 24 ago. 2013.

PLENTZ, Flávio; FAZZIO, Adalberto. Considerações sobre o Programa Brasileiro de Nanotecnologia. Ciência e Cultura, São Paulo, v. 65, n. 3, p. 23-27, jul. 2013. Disponível em: <http://cienciaecultura.bvs.br/pdf/cic/v65n3/a10v65n3. pdf>. Acesso em: 25 mar. 2016.

POPPER, Karl R. A lógica da pesquisa científica. 12. ed. Paulo: Cultrix, 2006. PORTAL BRASILEIRO DE CIÊNCIA E TECNOLOGIA. 2013. Disponível em: <pbct.inweb.org.br/pbc>. Acesso em: 10. dez. 2013.

POVOA, Luciano Martins Costa. Patentes de universidades e institutos públicos de pesquisa e a transferência de tecnologia para empresas no Brasil. 2008. $153 \mathrm{f}$. Tese (Doutorado em Economia) - Universidade Federal de Minas Gerais, Belo Horizonte, 2008. Disponível em: <http://www.bibliotecadigital.ufmg.br/dspace/ bitstream/handle/1843/AMSA-7FBNZ5/luciano_p_voa_2008.pdf?sequence=1>. Acesso em: 20 fev. 2016.

PREMEBIDA, Adriano; NEVES, Fabrício Monteiro; ALMEIDA, Jalcione.

Sociologias, Porto Alegre, v. 13, n. 26, p. 22-42, jan./abr. 2011. Disponível em: $<$ http://seer.ufrgs.br/index.php/sociologias/article/view/19919/11560> Acesso em: 25 jan. 2016. 
PRETTO, Nelson De Luca; SILVEIRA, Sérgio da (Org.). Além das redes de colaboração: internet, diversidade cultural e tecnologias do poder. Salvador: EDUFBA, 2008.

PROGRAMA Institutos Nacionais de C\&T: documento de orientação aprovado pelo comitê de coordenação em 29 de julho de 2008. In: CNPq. Edital No 15/2008 -MCT/CNPq/FNDCR/CAPES/FAPEMIG/ FAPEMIG/FAPERJ/FAPESP/INSTITUTOS NACIONAIS DE CIÊNCIA E TECNOLOGIA. Brasília, 2008. Disponível em: <http://www.fapesp.br/chamadas/inct2008.pdf>. Acesso em: 19 mar. 2016. PROJETO Genoma Humano. 2013. Disponível em: <http://www. minutobiomedicina.com.br/postagens/2013/07/29/projeto-genoma-humano/>. Acesso em: 19 nov. 2015.

REGULAMENTO: condições específicas. In: CNPq. Edital No 15/2008-MCT/ CNPq/FNDCR/CAPES/FAPEMIG/FAPEMIG/FAPERJ/FAPESP/INSTITUTOS NACIONAIS DE CIÊNCIA E TECNOLOGIA. Brasília, 2008. Disponível em: <http://www.fapesp.br/chamadas/inct2008.pdf>. Acesso em: 19 mar. 2016 REIS, Filipe. Actor network theory (ANT) e etnografia dos media. In: REUNIÃO BRASILEIRA DE ANTROPOLOGIA, 27., 2010., Belém. Anais... Belém: Associação Brasileira de Antropologia, 2010. Disponível em: <http:// www.abant.org.br/conteudo/ANAIS/CD_Virtual_27_RBA/arquivos/grupos_ trabalho/gt32/fr.pdf>. Acesso em: 29 jan. 2016.

REZENDE, Sergio Machado. Momentos da ciência e tecnologia no Brasil: uma caminhada de 40 anos pela C\&T. Rio de Janeiro: Vieira \& Lent, 2010.

RIGOLIN, Camila Carneiro; HAYASHI, Carlos Roberto Massao; HAYASHI, Maria Cristina Piumbato Innocentini. Métricas da participação feminina na ciência e tecnologia no contexto dos INCTs: primeiras aproximações. Liinc em Revista, Rio de Janeiro, v. 9, n. 1, p. 143-170, maio 2013. Disponível em: <http:// www.ibict.br/liinc>. Acesso em: 12 jun. 2016.

RIZZATO, Alessandro et al. (Org.). Guia de boas práticas para interação. 3. ed. São Paulo: AMPEI, 2015. Disponível em: <http:/|anpei.tempsite.ws/download/2015/ Guia_Anpei_Interacao_ICT_Empresa.pdf>. Acesso em: 28 jun. 2016. 
RODRIGUES, Ricardo. Programa de Comutação Bibliográfica COMUT: 25 anos de funcionamento. Curitiba, 2005. Texto lido pelo autor na cerimônia comemorativa dos 25 anos de criação do COMUT, em sessão especial, durante do XXI. Congresso Brasileiro de Biblioteconomia, Documentação. Disponível em: <http://www.antoniomiranda.com.br/ciencia_informacao/comut_ricardo. html>. Acesso em: 1 jun. 2011.

RODRIGUEZ, Mercedes. Nanotecnología y Big Data: la próxima revolución digital. Euroresidentes, Alicante, 2015. Disponível em: <https://www. euroresidentes.com/tecnologia/nanotecnologia/nanotecnologia-y-big-data-laproxima>. Acesso em: 23 set. 2015.

ROURE, David; HENDLER, James. E-Science: the grid and the semantic web. IEEE Intelligent Systems, Los Alamitos, US, v. 19, n. 1, p. 65-71, jan./ fev. 2004. Disponível em: <http://ieexplore.iee.org/stamp/stamp. jsp?tp=\&arnumber=1265888>. Acesso em: 10 ago. 2013.

RYDER, Martin. What is Actor-Network Theory? [2016]. Disponível em: $<$ https:// webcache.googleusercontent.com/search?q=cache:jLFboLnHfSkJ:https:// carbon.ucdenver.edu/ mryder/itc/ant_dff.html+\&cd=2\&hl=ptBR\&ct $=\operatorname{clnk} \& g l=b r>$. Acesso em: 23 jan. 2016.

SANTOS JUNIOR, Jorge Luiz dos. Ciência do futuro: a comunidade de pesquisa e o ciclo da política de nanociência no brasil. 2011. 176 f. Tese (Doutorado em Ciências) - Instituto de Ciências Humanas e Sociais, Universidade Federal Rural do Rio de Janeiro, Rio de Janeiro, 2011. Disponível em: <http://r1.ufrrj.br/cpda/ wp-content/uploads/2012/07/Tese_Jorge_Luiz_Junior_2011.pdf $>$. Acesso em: 17 mar. 2015.

SCHOTTLAENDER, Brian E. C. An idiosyncratic perspective on the history and development at University California, San Diego, of support for cyberinfrastructure-enabled e-science. In: MARCUM, Deanna B.; GEORGE, Gerald (Ed.). The data deluge: can libraries cope with e-Science? Santa Barbara; Denver: Libraries Unlimited, 2010. Disponível em: <https:// www.academia.edu/1094996/E-SCIENCE_AT_JOHNS_HOPKINS_ UNIVERSITY?auto=download $>$. Acesso em: 13 abr. 2016. 
SCHULZ, Peter. De volta para o futuro: os precursores da nanotecnociência. Cadernos IHU Ideias, São Leopoldo, v. 95, p. 1-17, 2008. Disponível em: <http:// nano.iiep.org.br/sites/default/files/Futuro_PeterSchulz.pdf>. Acesso em: 14 maio 2016.

SCHULZ, Peter. Nanotecnologia: uma história um pouco diferente. Ciência Hoje, Rio de Janeiro, v. 52, n. 308, p. 26-29, out. 2013. Disponível em: <http:// cienciahoje.uol.com.br/revista-ch/2013/308/pdf_aberto/nanotecnologia308. pdf/at_download/file>. Acesso em: 11 maio 2016.

SEGATA, Jean. Resenhas. Itha - Revista de Antropologia, Florianópolis, v. 14, n. 2, p. 238-243, jul./dez. 2012. Disponível em: <https://periodicos.ufsc.br/index. php/ilha/article/view/2175-8034.2012v14n1-2p238/24017>. Acesso em: 16 fev. 2015.

SIDONE, O. J. G.; HADDAD, E. A.; MENA-CHALCO, J. Padrões de colaboração científica no Brasil: o espaço importa? TD Nereus, São Paulo, p. 1-34, 2013. Disponível em: $<$ http://www.usp.br/nereus/wp-content/uploads/TD_ Nereus_09_2013_v2.pdf $>$. Acesso em: 3 jan. 2014.

SILVA, Alzira Karla Araújo da. Redes de coautoria em Ciência da Informação no Brasil: dinâmica na produção científica dos atores mediada pela ANCIB. 2012. 251 f. Tese (Doutorado em Ciência da Informação) - Escola de Ciência da Informação, Universidade de Minas Gerais, Belo Horizonte, 2012a. Disponível em: <http:/| www.bibliotecadigital.ufmg.br/dspace/bitstream/handle/1843/BUOS96SGC6/tese__alzira_karla__redes_sociais_de_coautoria_em_ci_ncia_da_ informa_o_no_brasil.pdf?sequence=1.> Acesso em: 6 abr. 2016.

SILVA, Cylon Gonçalves da. O que é nanotecnologia? Comciência - Revista Eletrônica em Jornalismo Cientifico, São Paulo, v. 37, nov. 2002a. Disponível em: <http://www.comciencia.br/reportagens/framereport.htm/O que é nanotecnologia?> Acesso em: 29 ago. 2015.

SILVA, Silvio Bitencourt da; BIGNETTI, Luiz Paulo. A inovação social e a dinâmica de inovação aberta na rede brasileira de Living Labs. In: ENCONTRO DA AMPAD, 26., 2012, Rio de Janeiro. Anais... Rio de Janeiro, 2012. p. 1-16. 
Disponível em: <http://www.anpad.org.br/admin/pdf/2012_GCT1794.pdf>. Acesso em: 18 abr. 2016.

SOARES, Nelson Vicente. Acoplador óptico: o que é e para que serve ? Render Blog, 2013. Disponível em: <http://blog.render.com.br/diversos/acopladoroptico-o-que-e-e-para-que-serve/>. Acesso em: 17 abr. 2016.

SBPC. Ciência, tecnologia e inovação para um Brasil competitivo. São Paulo, 2011. Disponível em: <http://www.sbpcnet.org.br/site/publicacoes/outraspublicacoes/cti.pdf>. Acesso em: $12 \mathrm{dez} .2014$.

SOEHNER, Catherine et al. E-science and data support services: a study of ARL member institutions. Washington: ARL, 2010. Disponível em: <http://www.arl. org/storage/documents/publications/escience-report-2010.pdf>. Acesso em: 2 abr. 2014.

SOLLA PRICE, Derek J. de. O desenvolvimento da ciência: análise histórica, filosófica, sociológica e econômica. Tradução de Simão Mathias com colaboração de Gilda Maria Braga. Rio de Janeiro: Livros Técnicos e Científicos, 1976.

SOON, Carol; PARK, Han. The rise of e-Science in Asia. Dreams and realities for Social Science research: case studies of Singapore and South Korea. In: JANKOWSKI, Nicholas W. E-research: transformation in scholarly practice an enhanced publication accompanying the traditionally published book. [S.1.]: Routledge, 2009. Disponível em: <http://scholarly-transformations. virtualknowledgestudio.nl/table-of-contents/chapter6>. Acesso em: 10 jul. 2012.

SOUZA, Iara Maria de Almeida; SALES JÚNIOR, Dário Ribeiro de. Apresentação. In: LATOUR, Bruno. Reagregando o social: uma introdução à Teoria do Ator-Rede. Salvador: EDUFBA; Bauru: EDUSC, 2012. p. 11-15.

TECSAUGEM IMPORTAÇÃO E COMÉRCIO LTDA. Nanotecnologia. 2016. Disponível em: <http://www.tecsaugem.com.br/nanotecnologia.php>. Acesso em: 20 jul. 2016. 
TOLLE, Kristin et al. Conclusões. In: HEY, Tony; TANSLEY, Stewart; TOLLE, Kristin (Org.). O quarto paradigma: descobertas científicas na era da eScience. São Paulo: Oficina de Textos, 2011.

TOMAÉL, Maria Inês. Redes de conhecimento. DataGramaZero - Revista de Ciência da Informação, Rio de Janeiro, v. 9, n. 2, p. 1-13, abr. 2008. Disponível em: <http://www.dgz.org.br/abr08/Art_04.htm>. Acesso em: 29 maio. 2014. TOMAÉL, Maria Inês; ALCARÁ, Adriana Rosecler; DI CHIARA, Ivone Guerreiro. Das redes sociais à inovação. Ciência da Informação, Brasília, v. 34, n. 2, p. 93-104, 2005. Disponível em: <http://www.ibict.br/cionline/viewartcle. php?id=710\&layout=html>. Acesso em: 17 ago. 2006.

TORRES, Lúcia Beatriz. INCTs na berlinda: Brasília sedia reunião para avaliar desempenho dos 122 Institutos Nacionais de Ciência e Tecnologia. INCT-InofarInstituto Nacional de Ciência e Tecnologia de Fármacos e Medicamentos, 2010. Disponível em: <http://www.inct-inofar.ccs.ufrj.br/not_inctberlinda.html>. Acesso em: 17 mar. 2016.

TORRES, Tércia Zavaglia; PEREIRA, Nadir Rodrigues; MAXIMO, Fernando Attique. Aprendizagem e disseminação de conhecimento nos colaboratórios das redes de pesquisa da Embrapa. In: SIMPÓSIO BRASILEIRO DE INFORMÁTICA NA EDUCAÇÃO, 23., 2012, Rio de Janeiro. Anais... Rio de Janeiro: SDC, 2012. Disponível em: <http://ainfo.cnptia.embrapa.br/digital/ bitstream/item/75339/1/SBIE.pdf>. Acesso em: 21 fev. 2015.

USAMI, Hitohide et al. Creating a research community by AHS on Heterogeneous Large Scale Grid Environments. In: COMPUTER SCIENCES AND CONVERGENCE INFORMATION TECHNOLOGY (ICCIT), 6., 2011, Seogwipo. Proceeding... Estados Unidos: IEEE, 2011. p. 848-854. Disponível em: $<$ http://ieeexplore.ieee.org/xpls/abs_all.jsp?arnumber=6316736\&tag=1>. Acesso em: 9 jul. 2016.

VALENTIM, Marta Lígia Pomim. Informação em ciência e tecnologia: políticas, programas e ações governamentais - uma revisão de literatura. Ciência da 
Informação, Brasília, v. 31, n. 3, p. 92-102, set./dez. 2002. Disponível em: <www. scielo.br/pdf/ci/v31n3/a10v3n3.pdf>. Acesso em: 3 abr. 2014.

VANZ, Samile Andrea de Souza. As redes de colaboração científicas no Brasil: (20042006). 2009. 204 f. Tese (Doutorado em Comunicação e Informação) - Faculdade de Biblioteconomia e Comunicação, Universidade Federal do Rio Grande do Sul, Porto Alegre, 2004. Disponível em: <http://www.lume.ufrgs.br/bitstream/ handle/10183/17169/000711634.pdf>. Acesso em: 2 abr. 2016.

VANZ, Samile Andrea de Souza; STUMP, Ida Regina Chittó. Colaboração científica: revisão teórico-conceitual. Perspectivas em Ciência da Informação, Belo Horizonte, v. 15, n. 2, p. 42-55, maio/ago. 2010. Disponível em: <www.scielo.br/ pci/v15n2/a04v15n2.pdf>. Acesso em: 1 ago. 2013.

VAZ, Glauber José. E-Science na Embrapa. Campinas: Embrapa Informática Agropecuária, 2011. (Documentos, 117). Disponível em: <http://www.infoteca. cnptia.embrapa.br/bitstream/doc/921022/1/Livrodoc1171.pdf > . Acesso em: 20 abr. 2014.

VIEIRA, Letícia Alves. Ciência da informação e redes de colaboração acadêmica: diálogos, constituição e perspectivas. 2009. 160 f. Dissertação (Mestrado em Ciência da Informação) - Universidade Federal de Minas Gerais, Escola de Ciência da Informação, Belo Horizonte, 2009. Disponível em: <http://www. bibliotecadigital.ufmg.br/dspace/bitstream/handle/1843/ECIC-855PVQ/vieira_ leticia_alves_ci_e_redes_de_colabora_o_acad_mica.pdf?sequence $=1>$. Acesso em: 2 dez. 2013.

VIOTTI, Eduardo Baumgratz; MACEDO, Mariano de Matos. Indicadores de ciência, tecnologia e inovação no Brasil: uma introdução. In: VIOTTI, Eduardo Baumgratz; MACEDO, Mariano de Matos (Org.). Indicadores de ciência, tecnologia e inovação no Brasil. Campinas: Unicamp, 2003. p. 45-87.

VULHERME, Julio. O conceito de colaboração. 2013. Disponível em: <http://www. voitel.com.br/ExtranetArquivosDownload/WhitePaperJulioVulherme.pdf>. Acesso em: 17 set. 2013. 
WASSERMAN, Stanley; FAUST, Katherine. Social network analysis: methods and applications. Cambridge: Cambridge University, 1994. (Structural analysis in the social sciences). Disponível em: $<$ http://www.asecib.ase.ro/mps/Social\%20 Network\%20Analysis\%20[1994].pdf>. Acesso em: 1 jul. 2016.

WHITMIRE, Amanda L. Thoughts on "eResearch": a scientist's perspective. Journal of eScience Librarianship, Massachusetts, US, v. 2, n. 2, jul. 2013. Disponível em: $<$ http://escholarship.umassmed.edu/cgi/viewcontent. cgi? article=1045\&context=jeslib $>$. Acesso em: 30 jul. 2013.

WITTER, Geraldina Porto. Redes sociais e sistemas de informação na formação de pesquisadores. In: POBLACIÓN, Dinah Aguiar; MUGNAINI, Rogério; RAMOS, Lúcia Maria S. V. Costa (Org.). Redes sociais e colaborativas em informação científica. São Paulo: Angellara, 2009. p. 169-201.

ZANETI-RAMOS, Betina Giehl; CRECZYNSKI-PASA, Tânia Beatriz. O desenvolvimento da nanotecnologia: cenário mundial e nacional de investimentos resumo. Revista Brasileira de Farmácia, Rio de Janeiro, v. 89, n. 2, p. 95-101, 2008. Disponível em: <http://rbfarma.org.br/files/pag_95a101_ desenv_nanotecnologia.pdf $>$. Acesso em: 15 maio 2016.

ZIMAN, John. Conhecimento público. Belo Horizonte: Itatiaia; São Paulo: EDUSP, 1979. (O Homem e a ciência, 8). 


\section{APÊNDICE A - MODELO DE ANÁLISE}

\begin{tabular}{|c|c|c|c|c|}
\hline \multicolumn{5}{|c|}{ MODELO DE ANÁLISE } \\
\hline \multirow{23}{*}{ 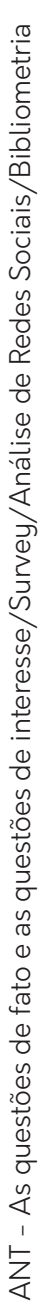 } & CATEGORIAS & $\begin{array}{l}\text { TRIANGULAÇÃO } \\
\text { METODOLÓGICA }\end{array}$ & DIMENSÃO & $\begin{array}{l}\text { INDICADORES/ } \\
\text { VARIÁVEIS }\end{array}$ \\
\hline & \multirow{5}{*}{$\begin{array}{c}\text { Práticas e Redes } \\
\text { Colaborativas } \\
\text { para Inovação }\end{array}$} & \multirow{5}{*}{$\begin{array}{c}\text { ANT - Identificação } \\
\text { das ações/Análise de } \\
\text { Redes Sociais/Análise } \\
\text { de Conteúdo }\end{array}$} & \multirow{5}{*}{ Atividades } & Colaboração \\
\hline & & & & Internacionalização \\
\hline & & & & Inovação \\
\hline & & & & Interação/Integração \\
\hline & & & & $\begin{array}{l}\text { Formação de recursos } \\
\text { humanos }\end{array}$ \\
\hline & \multirow{3}{*}{$\begin{array}{l}\text { e-Science - } \\
\text { Infraestrutura } \\
\text { e suporte para } \\
\text { pesquisa }\end{array}$} & \multirow{3}{*}{$\begin{array}{c}\text { ANT - } \\
\text { Reconhecimento dos } \\
\text { objetos/Survey/ } \\
\text { Análise de Conteúdo }\end{array}$} & Modelo & INCT/e-Science \\
\hline & & & \multirow{2}{*}{ Objetos } & Infraestrutura \\
\hline & & & & Recursos \\
\hline & \multirow{14}{*}{$\begin{array}{c}\text { Políticas Públicas } \\
\text { Programa } \\
\text { Institutos } \\
\text { Nacionais } \\
\text { de Ciência e } \\
\text { Tecnologia }\end{array}$} & \multirow{6}{*}{$\begin{array}{c}\text { ANT - Natureza } \\
\text { do grupo/Survey/ } \\
\text { Análise de Conteúdo }\end{array}$} & \multirow{6}{*}{$\begin{array}{c}\text { Caracterização } \\
\text { dos INCTs e } \\
\text { pesquisadores }\end{array}$} & Titulação \\
\hline & & & & Bolsas \\
\hline & & & & Cargos \\
\hline & & & & Gênero \\
\hline & & & & Faixa etária \\
\hline & & & & Localização \\
\hline & & \multirow{8}{*}{$\begin{array}{c}\text { ANT - Identificação } \\
\text { das ações/ } \\
\text { Bibliometria/Análise } \\
\text { de Conteúdo }\end{array}$} & \multirow{6}{*}{$\begin{array}{l}\text { Produção } \\
\text { científica }\end{array}$} & Tipologia \\
\hline & & & & Produtividade \\
\hline & & & & Autoria \\
\hline & & & & Fonte \\
\hline & & & & Idioma \\
\hline & & & & Nacionalidade \\
\hline & & & \multirow{2}{*}{$\begin{array}{l}\text { Transferência } \\
\text { de } \\
\text { conhecimento e } \\
\text { tecnologia }\end{array}$} & Capacitação \\
\hline & & & & Difusão da ciência \\
\hline
\end{tabular}

Fonte: Elaboração da autora. 


\section{APÊNDICE B - CARACTERIZAÇÃO METODOLÓGICA DA PESQUISA}

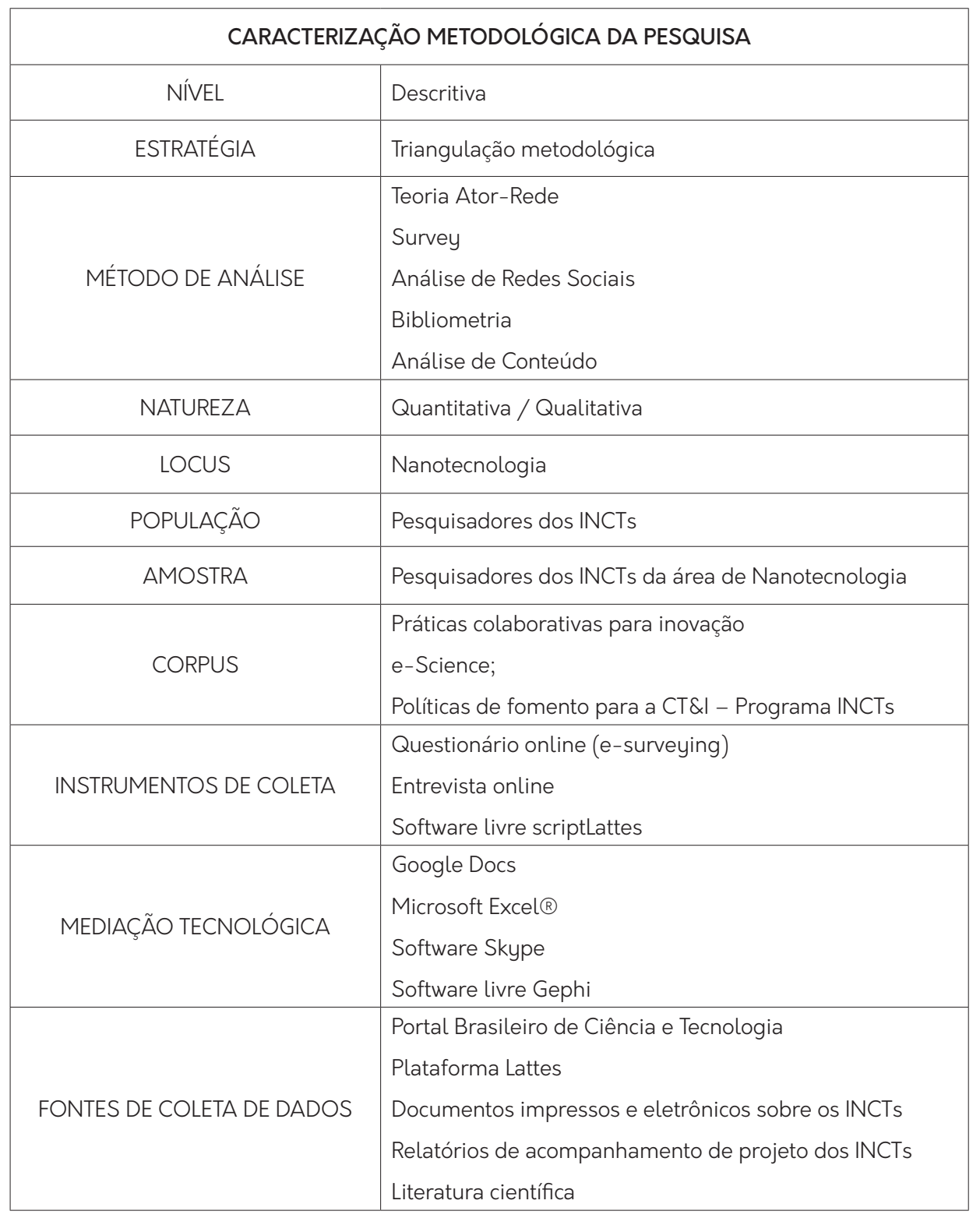

Fonte: Elaboração da autora baseada em Silva (2012a, p. 70). 
COLOFÃO

$\begin{aligned} \text { Formato } & 170 \times 240 \mathrm{~mm} \\ \text { Tipologia } & \text { Orkney / Albertina } \\ \text { Papel } & \text { Miolo Alta Alvura } 75 \mathrm{~g} / \mathrm{m}^{2} \\ & \text { Capa Cartão Supremo } 300 \mathrm{~g} / \mathrm{m}^{2} \\ \text { Impressão } & \text { Edufba } \\ \text { Acabamento } & \text { I. Bigraf } \\ \text { Tiragem } & 300 \text { exemplares }\end{aligned}$

